Challenges to the Power of Zeus in Early Greek Poetry

Noriko Yasumura

Thesis submitted for the degree of Doctor of Philosophy University College London

London University

2003

1 
ProQuest Number: U643385

All rights reserved

INFORMATION TO ALL USERS

The quality of this reproduction is dependent upon the quality of the copy submitted.

In the unlikely event that the author did not send a complete manuscript and there are missing pages, these will be noted. Also, if material had to be removed, a note will indicate the deletion.

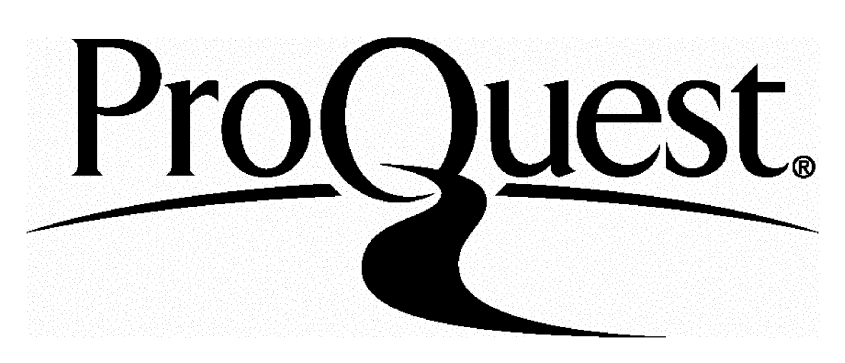

ProQuest U643385

Published by ProQuest LLC(2016). Copyright of the Dissertation is held by the Author.

All rights reserved.

This work is protected against unauthorized copying under Title 17, United States Code. Microform Edition (c) ProQuest LLC.

\author{
ProQuest LLC \\ 789 East Eisenhower Parkway \\ P.O. Box 1346 \\ Ann Arbor, MI 48106-1346
}




\section{Abstract \\ Challenges to the Power of Zeus in Early Greek Poetry}

In the earliest extant works of Greek literature, Zeus reigns supreme in the Olympian hierarchy. However, throughout the early Greek portrayals of him, there are allusions -- scattered and scanty as they may be -- to threats of rebellion which challenge Zeus' supremacy. This thesis examines these passages, drawn from Homer, Hesiod and the Homeric Hymns, to offer new interpretations of these texts. While focusing on the theme of cosmic/divine strife, I also reveal hidden logic and lost legends underlying these texts: discoveries of significance to the improved understanding of early Greek poetry.

Chapter one, focusing on Thetis' supplication, examines the crisis of Zeus in Iliad 1. I analyse the (mythological) theme of the son who is mightier than his father, interpreting Achilles and Peleus' relationship in terms of succession myth.

Chapter two explores the Golden Chain of Hera in Iliad 15. Retracing a lost Gigantomachia epic, I view the incident from the perspective of cosmic strife, discussing Hera's rebellion and the role of Heracles in this rebellion.

Drawing on the re-evaluation of the Gigantomachia, Chapter three investigates the war between the gods in the Iliad, concentrating on antagonism between Zeus and Poseidon, which reaches its end with Zeus' reordering of the universe. 
Chapter four reinterprets the Hesiodic account of Athena's birth, offering solutions as to how and why Zeus achieves his final conquest in the succession story.

Chapter five considers the Typhon-story in the Homeric Hymn to Apollo. Examining this hymn from the broad perspective of the struggle for cosmic power, I re-integrate this story into the hymn.

Chapter six focuses on the love of Aphrodite and Anchises in the Hymn to Aphrodite. I explore the dual themes of mortality and the bitter sorrow of Aphrodite - defeated by Zeus and diminished in power. 


\section{Table of Contents}

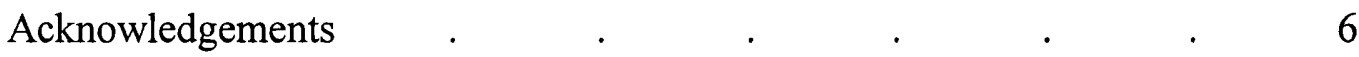

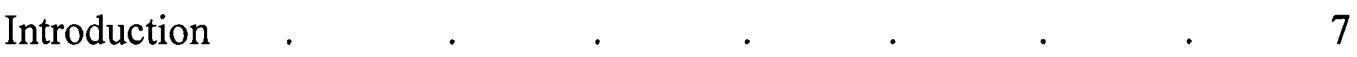

Chapter I The Threat of Thetis . $\quad$. $\quad$. $\quad$. $\quad 24$

1. The supplication of Thetis . . . . . . . . . 25

2. Generational Strife . $\quad . \quad$. $\quad . \quad$. $\quad . \quad 35$

3. Peleus and Achilles $\quad . \quad$. $\quad . \quad$. $\quad . \quad 46$

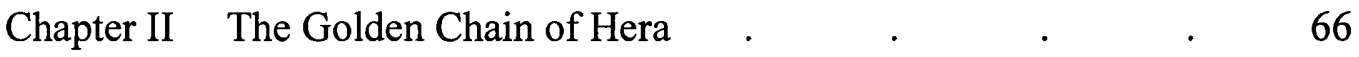

1. The $\delta \epsilon \sigma \mu$ ós of the gods in the Iliad . $\quad . \quad 67$

2. The golden chain of Hera . $\quad$. $\quad$. $\quad$. $\quad$. $\quad 77$

3. Heracles: the motive for the golden chain . $\quad$. $\quad 85$

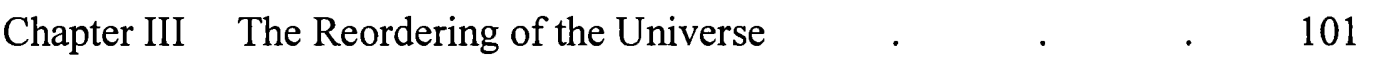

1. The 'tug of war' between Zeus and Poseidon . . $\quad$. 102

2. The wrath of Zeus and Poseidon . . . . $\quad$. 112

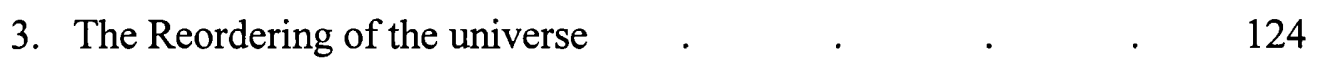

Chapter IV The Birth of Athena $\quad$. $\quad$. $\quad$. $\quad$. 133

1. Near Eastern succession myth and Hesiod's Theogony . $\quad 133$

2. The Hesiodic accounts: the route to Zeus' victory . . 140

3. The birth of Athena . . . . . $\quad 150$

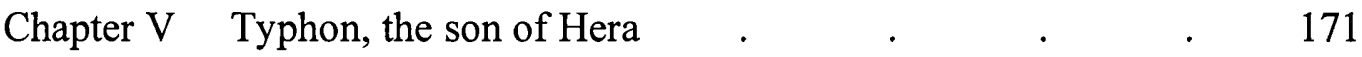

1. The dragon . . . . . 172

2. The Arrangement of the motifs of the dragon and Typhon $\quad . \quad 174$

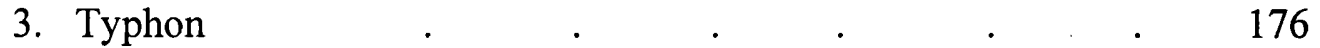

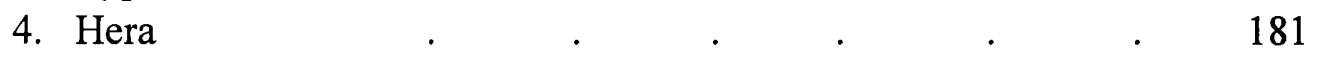

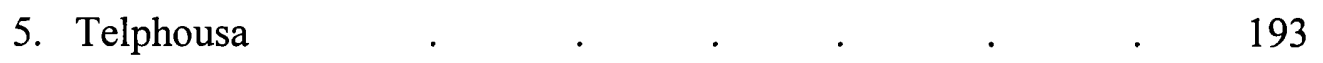




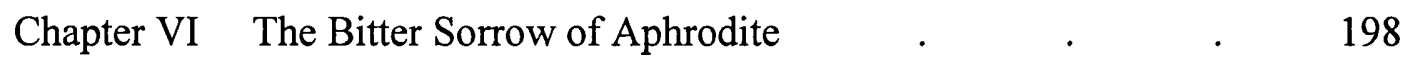

1. Human limitation and irony $\quad$. $\quad . \quad$. $\quad 200$

2. The sorrow of Aphrodite . $\quad . \quad$. $\quad . \quad$. 220

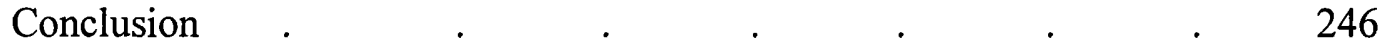

Abbreviations . $\quad . \quad$. $\quad . \quad$. $\quad . \quad 250$

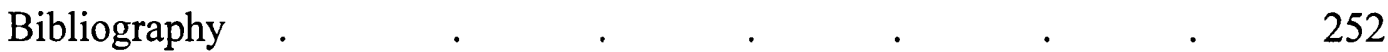




\section{Acknowledgements}

I could not have completed this thesis without generous support from a large number of people, who generously spared me their time and offered me invaluable insights and advice. I am especially grateful to Professor Richard Janko, my supervisor, who kept me on the right track. He always had time to read and comment on my work; his support and encouragement were generous and for this I will always be grateful. I am indebted beyond measure to Professor Pat Easterling. From the time I first met her in Cambridge in 1994, her exceptional intellectual guidance has been as unfailing as the spirit of her moral support. It has been my privilege to know her and enjoy all the benefits of her generous nature.

I would like to acknowledge the financial support provided by Kanazawa University in Japan, which enabled me to complete this work. I also express my deep gratitude to my colleagues at Kanazawa University, who generously took on all of my duties while I was on sabbatical in 2001-2002.

Special thanks are due to my many friends, in particular to Dr Natalie Tchernetska who have always sustained me on this long journey. Above all, I would like to thank Dr Victoria Jennings and Dr Andrea Katsaros, who read my manuscripts carefully, tirelessly corrected my English, and offering much valuable advice. Their patience and support were indispensable for the completion of this thesis.

Finally, I would like to thank my family for their unlimited empathy, understanding and patience. 


\section{Introduction}

In this dissertation I offer an innovative interpretation of a number of early Greek epic texts in which I have found common compositional connections through the theme of the accomplishment and maintenance of Zeus' Olympian supremacy in the face of the challenges and challengers for cosmic domination. This study examines the traces - the legacy of predecessors in the poetic tradition - contained in early Greek poetry. In the earliest extant works of Greek literature, Zeus reigns supreme in the Olympian hierarchy. By the eighth century, the concept of the Olympian 'family' had crystallised: they are the principal mythical figures in epic, and Zeus' power over them is already secure. However, there are indications that before this time, Zeus faced and overcame challenges which threatened his rule over the universe. In the Iliad, Poseidon and Hera always appear in alliance against Zeus; and his son and daughters, Apollo, Aphrodite and Athena, are also problematic figures deserving of consideration for their roles in familial internecine conflicts.

There is no indication of Zeus' supremacy in the Mycenaean documents. The religious tablets from Pylos contain a great number of what appear to be the names of gods, ${ }^{1}$ among whom Poseidon is clearly the most significant. For example, in Pylos tablet

\footnotetext{
${ }^{1}$ It is surprising that there are so many deities on the Pylos tablets who are unknown in the classical period; for example, manasa, dopota, and dirimijo (Tn 316). This seems to indicate that Mycenaean society, at least in Pylos, allowed variety in religious devotion, although Poseidon is undoubtedly the most important among the gods listed. Because of the scanty evidence, it is difficult to get much of the religious information at the Mycenaean sites other than Pylos. Chadwick (1976) 15 points out that 'the homogeneity of Mycenaean culture is so marked, that it would be strange if other parts of Greece behaved very differently. ' If this holds true, we might be able to think that it was a general phenomena that a variety of gods were worshipped in the Mycenaean cites.
} 
$\operatorname{Tn} 316,{ }^{2}$ thirteen divine names are present, including Zeus, Hera, Poseidon, Hermes, and Potnia (the other eight names remain uncertain). A golden vessel is dedicated to each of these figures, and some of them are also offered a human dedication. ${ }^{3}$ Poseidon's prestigious position in Pylos is attested by the fact that the shrine of Poseidon is listed at the top of the tablet and offered, specifically and exceptionally, two women. He is also an important deity on the other Pylos tablets: in the Es group of tablets, he receives annual contributions of grain (with three other uncertain figures), ${ }^{4}$ and his offerings are by far the largest; in Un 718 he is the recipient of a long list of offerings including oxen, sheep, goats, pigs, wheat, wine, honey, unguents, wool and cloth. ${ }^{5}$ From the perspective offered by these documents, Poseidon appears to be the strongest of all the gods in Pylos. This picture fits well with Odyssey 3. 43, which narrates how Telemachus and Athena (disguised as Mentor) join in celebrating the festival of Poseidon at Pylos.

Compared with the importance of Poseidon, Zeus does not appear as particularly consequential in the tablet documents. Tablet $\mathrm{Tn} 316$ records his ostensibly unexceptional nature: he is just an ordinary god, receiving the same quantity of offerings

\footnotetext{
${ }^{2}$ Palmer (1963) 265-6 suggests that the operation recorded in this tablet might be human sacrifice at the New Year festival for the purpose of the removal of the previous year's guilt and defilement. Chadwick (1976) 89-90 submits that this document might have been written in the last days of the existence of the palace of Pylos, since it is 'the most disgraceful piece of hastily compiled record of offerings.' One of the significant features of this tablet is that Zeus and Hera are mentioned together.

3 The content of tablet Tn 316 is as follows (see Ventris and Chadwick (1956) 286-9; Gallavotti ed., Inscriptiones Pyliae ad Mycenaeam Aetatem Pertinentes, 1961; Palmer (1963) 261-8):

those who get one golden vessel and two women: the precinct of Poseidon; one golden vessel and a man: Zeus, Hermes; one golden vessel and a woman: potinija (Potnia), the Dove-goddess, manasa, posidaeja (the feminine form of Poseidon?), diuja (the feminine form of Zeus?), Hera; one golden vessel only: tiriseroe (Trishero?), dopota, ipemedeja (Iphimedeia, the mother of Otos and Epialtes by Poseidon in Od. 11.305?), dirimijo (Drimios?).

${ }_{5}^{4}$ Es 645, 646, 647, 648, 649, 651, 652, 653, 703, 726, 728, 729.

5 Ventris and Chadwick (1956) 282-4 consider that the tablet records a glorified representation of ceremonial processions.
} 
as the other deities, some of whom may have been only minor gods since they are already unknown in classical times. Given Zeus' later sovereignty of the universe, it is undeniable that his characterisation has undergone a major transformation by the beginning of the archaic period.

It is not only Poseidon who must be considered a challenger of Zeus. A number of local deities, especially goddesses, existed. As Campbell writes, 'wherever the Greeks came, in every valley, every isle and every cave, there was a local manifestation of the mother-goddess of the world whom Zeus, as the great god of the patriarchal order, had to master in a patriarchal way'. ${ }^{6}$ The Zeus whom we encounter in Homer and Hesiod is the conqueror only after he has subdued all of these deities; and the texts of these poets preserve for us chance traces, albeit fragmentary, of Zeus' route to victory.

The concept of the Olympian family over which Zeus rules as father can be seen as a consequence of the drastic changes of that period. In the course of the eighth century, when the Iliad came to achieve its final shape, the Greek world grew increasingly receptive to new influences, both internal and external. Internally, the movement towards Panhellenism became prominent; ${ }^{7}$ and externally, the influence of the Near East grew pervasive from the latter half of the ninth century onwards in response to organised colonisation. ${ }^{8}$

\footnotetext{
${ }^{6}$ Campbell (1964) 149.

${ }^{7}$ The Olympic Games were organised in 776 B.C.; the great sanctuaries of Olympia, Delphi, Delos and Eleusis were established. See Nagy (1979) 9; Clay (1989) 8-9.

${ }^{8}$ Graf (1987) 95 proposes two periods of oral transmission of Near Eastern myths to the Greeks: the Mycenaean and the archaic periods. Graf considers the latter more likely, because there is no Canaanite influence in Hesiod; if the Greeks had taken over the oriental tales in Mycenaean times, some traces of Canaanite myth could be found, and the Hittite and Mesopotamian myths would hardly have been so prominent.
} 
The Panhellenic character of the Homeric epics is obvious: the diverse epic tradition is synthesised into a unified Panhellenic model. ${ }^{9}$ Since it was often performed on Panhellenic occasions, the epic theme itself is infused with and authorised by a Panhellenic spirit. ${ }^{10}$ The ideas of the sovereignty of Zeus and of Panhellenism itself seem, indeed, to have proceeded hand in hand. In particular, the creation of the myth of the birth of Athena from Zeus' head would have been 'the great landmark' ${ }^{11}$ in the establishment of a new kind of city-state. I deal with the Panhellenic ideal in Chapter IV.

Near Eastern influence on Greek myth is nowadays widely accepted. ${ }^{12}$ The Hurrian story of Kumarbi and the Babylonian creation poem of the Enuma Elish share a similar feature with Greek myth in the presentation of the concept of strife between the gods over the possession of supreme power in the universe. The Assyrian and Babylonian epic Atrahasis represents the idea of the division of the universe, which is paralleled in the Homeric account of the three portions of the world shared by Zeus, Poseidon and Hades (Il. 15. 187-95). ${ }^{13}$ The idea of strife among the gods for the highest power - the strongest god ruling over the other gods - is ubiquitous in the Near Eastern

\footnotetext{
${ }^{9}$ Rohde (1898) 39.

${ }^{10}$ Nagy (1979) 9: the death of Achilles is a theme officially celebrated in the 'paean' in worship of Apollo at Delphi, one of the Panhellenic institutions; in addition, Achilles was traditionally mourned by the women of Elis in a ceremony that inaugurated the Olympics every four years.

${ }^{11}$ Brown (1952) 138.

${ }^{12}$ Burkert (1992) 3-5 reviews the history of scholarship on orientalism and anti-orientalism in the late nineteenth century. He explores the dominance of the image of 'pure, self-contained Hellenism' especially among German scholars including Wilamowitz-Moellendorff, and how it was overtaken by three groups of new discoveries: the decipherment of cuneiform writing, the archaeological discovery of Mycenaean civilisation, and the recognition of an oriental phase in the development of archaic Greek art. West (1997) also deals with this subject, pointing out at p.586 that the Greek poets of the Archaic age were profoundly indebted to western Asia at many levels, such as mythical and literary motifs, cosmological and theological conceptions, formal procedures, technical devices, figures of speech, even phraseology and idioms.

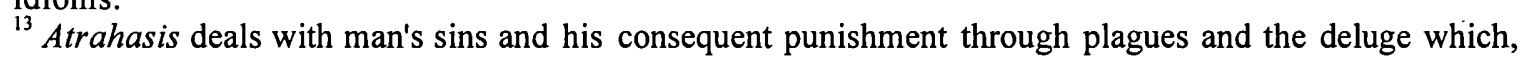
notoriously, provides a parallel to the biblical motivation for the Flood. It also offers features consistent
} 
epics.

We can also connect pre-Greek Indo-European poetic traditions to the tales of Zeus' sovereignty. For example, Dumézil analyses the cognate theme of war as the divine solution for overpopulation in the Mahãbhãrata and (the Trojan war) in the Cypria. ${ }^{14}$ Eliade discusses the cosmogonic and metaphysical value in the Rig Veda of 'binding', ${ }^{15}$ a theme also to be found in the lliad and in Hesiod in connection with generational strife and cosmic sovereignty. I discuss the Near Eastern and pre-Greek Indo-European influences on Greek myth in Chapters IV and VI.

Let me clarify my methodology: in each chapter I view the text as primary, employing detailed philological analysis and the technique of close-reading. I show how the quest of Zeus for supremacy received different treatments in different genres - the epic story-telling of Homer, the didactic style of Hesiod, and the hymnic poems. Nevertheless, the juxtaposition of these texts also demonstrates the existence of a significant degree of thematic cross-over and harmony. Therefore, when these results are extrapolated back to each text, their interconnections prove consequential to a more comprehensive understanding of each work both as an individual, generically structured epic, didactic, or encomiastic piece, and as a representative part of a broader, thematically-linked corpus of mythic material. The insight characterising this study is, then, that an approach grounded, synthetically, in the scrutiny of each genre, has the

with Greek myth: the gods have an assembly, and the mightiest god among them (Ea) determines the beginning and the end of the flood.

${ }^{14}$ Dumézil (1968) 168-9. 
potential to offer an improved understanding of the relationship between different kinds of literature.

My investigation makes manifest the existence of two, often intertwined, thematic threads woven throughout these texts. The first is the threat of the mighty son with the potential to overcome and usurp his father. This image is perceptible in Book One of the Iliad - the subject of Chapter I - and runs through the other texts under discussion. I discuss the story of the binding of Zeus (Il. 1. 399-400) and Thetis' supplication (Il. 1. 493-530), focusing on how the mythological theme of the threat of a son mightier than his father functions in the scene between Zeus and Thetis, and also throughout the Iliad. My analysis reveals, for example, that the birth of Athena (Theog. 886-91: see Chapter IV) is pivotal to Zeus' acquisition of supremacy because, as a maiden daughter born from Zeus himself, she breaks a recurrent pattern of menace. The leitmotif reappears in Chapter VI, in my exploration of Aphrodite's disempowerment in the Hymn to Aphrodite: apparently not an explicit challenger to Zeus, nevertheless, her incorporation into the patriarchal Olympian family entails the loss of much of her personal power. I demonstrate that a major theme of the Hymn is the celebration of the solidarity of Olympian society at the expense of Aphrodite's personal happiness. In my investigation of the Hymn to Apollo - Chapter V - I illustrate how the theme of the threatening and mighty son operates on two levels in the twin stories of Typhon and Apollo. Against a background of generational strife - a motif casting its shadow over so many of the texts under discussion - Typhon, son of Hera, challenges the power of Zeus in a narrative

\footnotetext{
${ }^{15}$ Eliade (1961) 98: the god Varuna has the magic power to bind and unbind men at a distance.
} 
which emphasises the antagonistic role of the mother and son against the father. As the oppressive atmosphere of the Hymn's opening scene suggests, Apollo - another powerful son - might also have challenged Zeus. Instead, he establishes overall peace: highlighting these parallels reveals, in my interpretation, that the central theme of this Hymn is the celebration of the reconciliation of father and son - or, rather, the father's successful deliverance from the son's potential threat.

Second to this, I emphasise another theme of the challenges to Zeus, namely that of the dangers represented by chthonic powers. My discussion concentrates, in particular, on the appearance of this theme of early Greek poetry in the alliance between Hera and Poseidon. In Chapter II, I interpret the myth of the golden chain of Hera (Il. 15. 16-33) as a marked indication of the persistent struggle between Zeus and Hera, in which Poseidon, overtly and covertly, always supports Hera. This insight enables me to establish plausible links with the broad epic tradition, such as the Gigantomachia on which, I argue, Homer draws. The result is a proposal for the reconstruction of the plot of this lost epic. Further, in my discussion of the Theomachy (Il. 20. 54-74; 21. 385-520) in Chapter III, I identify and trace the latent logic underlying this antagonism between Zeus and Poseidon - Zeus' final challenger - and examine how this logic is integrated by the poet into his account of the process of Zeus' reordering of the universe. Fundamental to this process, as I determine, is the analogy presented in the Iliad between the destiny of Achilles and that of Poseidon. My interpretations of the above-mentioned texts underline the often overlooked significance of cosmic - divine - strife as a popular theme in early Greek poetry. 
Thus, Zeus had to conquer these powers, dangerous sons and chthonic potentates, before he gained supremacy on Olympus. Among threats to the power of Zeus, we have not only the explicit challenger, such as Typhon, but also implicit challengers, such as Hera, Poseidon and Aphrodite. They might not have actually caused a war against Zeus, but our texts show that they in fact oppose him or at least behave insubordinately towards him. Opposition and insubordination could be a threat of subversion, if the proper countermeasures could not be devised. I discuss even Ares as a challenger in Chapter III, who is insubordinate towards Zeus. There could be various types of challenges and various levels of threats. Zeus conquered all these threats before they become a real rebellion.

I structure my investigation in order of the date of composition of the texts: the Iliad (Chapters I-III), the Theogony (Chapter IV), the Hymn to Apollo (Chapter V), and the Hymn to Aphrodite (Chapter VI). ${ }^{16}$ As a consequence of my approach through generic and thematic integration, it is also possible to appreciate this analysis by considering the myths according to the sequence of challenges to Zeus' power: that is, (1) the birth of Athena; (2) Typhon, the son of Hera; (3) the threat of Thetis; (4) the golden chain of Hera; (5) the reordering of the Universe; and (6) the bitter sorrow of Aphrodite. I choose, however, not to emphasise this aspect of presentation: such an approach should involve analysis of all the challengers to Zeus' sovereignty, and would expand this study beyond manageable limits. I reserve the admission, and the ramifications of the

\footnotetext{
${ }^{16}$ The date of the hymns is not easy to determine. I follow AHS (1936) 183, who argue that the Hymn to Apollo is the oldest of the hymns. However Janko (1982) 132 dates the Hymn to Pythian Apollo to c. 585 - a date later than the composition of the Hymn to Aphrodite, c. 700BC. Cf. Chapter VI, n. 2.
} 
admission, of these other challenger figures - Prometheus, for example - for a further study.

I began my study fascinated by the number of references to challenges to the power of Zeus, and the significance which these fragmentary traces assume in the poems on close reading. My analysis reveals that these apparently arbitrary references can be considered, paradoxically, central to the theme of each work in which they appear. Germane to this is Taplin's observation,

As so often in Homer's narrative technique, a seed in the form of a passing hint or subtle implication grows, as the poem progresses, into a full-blown and explicit issue or theme. ${ }^{17}$

Identifying this cumulative or 'snowball' ${ }^{18}$ effect can provide a possible reconstruction of events which appear, on first reading, to be discrete. The obvious implication is that the theme of the resolution of the challenges to Zeus' power was of greater importance to the poets than has hitherto been acknowledged. A further implication is that the frequency of allusions to this theme in different genres of early Greek literature indicates that the ancient Greeks were particularly fond of the theme. We can postulate some of the manifold reasons for this: for instance, the competitiveness of Greek society laid the foundation for people's acceptance that Zeus' achievement of supreme Olympian power implied the defeat of his enemies and rivals. ${ }^{19}$ Alternatively, the Greeks' characteristically

\footnotetext{
${ }^{17}$ Taplin (1992) 55.

${ }^{18}$ Taplin (1992) 10.

${ }^{19}$ The idea of competition and the desire for victory seems to have been particularly important in ancient Greece. The principle of competition prevailed throughout society - in battle, sports, and even in the artistic fields. For example, in the Certamen, Homer and Hesiod compete in a poetic contest: the quality of the poets' songs is judged. The Hymn to Apollo presents the delightful festival in Delos (146-176),
} 
logical spirit of inquiry into the cause and processes of the phenomenal world made them receptive to the elaboration of the reasoning offered in the re-presentation of these myths in extended narratives.

I approach my theme with an interpretative methodology. For example, I consider the poetic effects of allusion (Ch. I, III and VI), ring composition (Ch. II and V), the story-inside-a-story technique (Ch. V), and the repetition of motifs (Ch. IV and V). Some of the passages that I evaluate are so-called 'digressions' (Ch. I, II, IV and V), which are often regarded as 'interpolations' or 'inventions'. ${ }^{20}$ My own view is, however, that on a unitarian reading, a consistent logic can be detected behind these digressions which permits the evaluation of their overall thematic relevance. This methodological approach has much in common with Taplin's 'soundings' of the Homeric texts: '...tracing the coherence of foreshadowings, back-references, cross-references, interlocking sequences -the "cobwebbing" of motifs and ideas. ${ }^{21}$

The aim of this study is to focus attention on the elements with which the ancient audience were familiar from their wide acquaintance with the epic tradition, but which we, being unfamiliar with them, have not necessarily recognised. ${ }^{22}$ Of course, we can

where hymns are recited in a contest. In the classical age, it is well known that dramas were performed in a contest situation. As Nagy (1990) 79 writes, 'the performance of poetry, from the day of the oral poets to the era of the rhapsodes, was by its nature a matter of competition'. In such a competitive society, the idea of gods who fight with each other would have been accepted without difficulty. However, Griffith (1990) 189 points out the ambiguity of the verdict at the contests, giving the example of the contest between Hesiod and Homer, and writes (p. 191) that the game need not come out to a 'zero-sum'. I agree with Griffith (pp. 196-7) that this 'contest-system' allowed the existence of alternative or contradictory versions of myth.

${ }^{20}$ For the extreme case, cf. Todorov (1977) 55 on the 'antidigressive law'.

${ }^{21}$ Taplin (1992) 8f.

${ }^{22}$ I pursue the problem in a direction similar to that of Slatkin (1991) 8, who writes that 'what we need is ...to recover as much as possible what an ancient "reading" might have been based on; or rather we might say that to gain greater access to what Homer's audience heard in the epics.' 
appreciate the poems even without further knowledge of such elements; but, as I will try to demonstrate, further knowledge can only bring us closer, in interpretation and appreciation, to the poems' ancient audiences. In tracing the hidden or apparently lost logic of the epic legends underlying our extant texts, we achieve an improved understanding of early Greek poetry. As Clay notes of the Homeric Hymn to Demeter,

The hymn, then, appears to lack certain crucial links of logic and motivation. But what is especially remarkable about these narrative gaps and inconsequences is that other extant versions of the myth organize many of the same components and motifs into a coherent narrative sequence, in which each change of scene or transition follows with admirable logic and clarity from what has preceded. There is good reason to suppose that at least some of these versions do not constitute later rationalized revisions of elements found in the hymns but, rather, that they preserve traditions older than the hymn itself. ${ }^{23}$

An intertextual reading of this kind -- a reading between the lines and beyond the text -must take into account two related elements. The first is the notion of a presupposed, 'ideal' audience receptive to the details of (and possibilities for) mythographic variants and/or to the wider epic tradition to which, I argue, the poet refers. ${ }^{24}$ For example, I suggest that the assumption of this audience's knowledge can allow the poet to curtail full explication of the underlying core of material on which he draws (see Chapter V). The question of audience 'appreciation' is vexed: as Taplin has noted, an audience is not 'homogeneous', though its members can possess much in common. Of course, not all audience members will appreciate every cross-reference or digression as the poet

\footnotetext{
${ }^{23}$ Clay (1989) 205.

${ }^{24}$ Reception, of course, lies beyond an author's control: see Martindale (1993) 13-16 on theoretical questions associated with the redescribability of texts by the 'implied reader'. I wish here merely to note that I am aware of the considerable pitfalls associated with the use of 'reader', 'hearer' and 'audience' in the context of the Homeric problem. In general, see Rutherford (1996) 9-15.
} 
intended. It is the epic poets' achievement to be able to approach this group on 'many different levels' -- and over such a long period of time. ${ }^{25}$

The second element which this methodological chapter must address is the poet's use of innovation within existing cores of material, and/or his invention beyond this same core. In Chapter VI we note that the poet of the Hymn to Aphrodite prefers the Homeric version of Aphrodite's birth to the Hesiodic (which, even allowing for uncertainties over the dating of the Hymn, we may assume that he knew). In the fifth-century tragedians we see even more pointed examples of differences from earlier cores of material: in the same chapter I compare the powerless Aphrodite of the Hymn and the effective Aphrodite of Euripides' Hippolytus.

In practice, of course, it is very difficult to determine to what extent traditional motifs remain in the Homeric stories, and to what extent these early poets are inventing. As Willcock has suggested, 'the parallelism between the mythological story and the immediate situation often appears to be the creation of the poet ... the poet was free to invent details within an already existing framework of legend. The background ... was there in the legends before Homer. ${ }^{26}$ While this is not only an important, but valid, assertion, it is equally valid to recognise the impossibility of distinguishing for certain between sheer invention and poetic allusion and innovation. 'Probability', ${ }^{27}$ by definition, remains only that. Dating alternative versions is fraught with difficulties, and is often a futile exercise. In addition, it is likely that we no longer possess all of the material on

\footnotetext{
${ }^{25}$ Taplin (1992) $10 \mathrm{f}$.

${ }^{26}$ Willcock (1964) 147.
} 
which these poetic 'innovators' drew. Any exploration of the mythological themes and threads which run through the epic corpus must, therefore, be dependent upon recognition of the element of 'probability' implicit in any judgement of narrative intention. Of course, close readings of texts of such complexity offer an abundance of alternative interpretations, of which mine is but one.

I make mention of 'cores of material'. I do not suggest that these registers of mythological variations existed, for the epic poets or their successors, in the form of a unique 'canon'. The fall of Hephaestus, not the only case of inconsistency in the Iliad, offers a glimpse of this available repertory: at 1.590 he is thrown from heaven by Zeus; at 18.395 this is carried out by Hera. The latter version, as I discuss in Chapter V, is followed by the Hymn to Apollo. ${ }^{28}$ If we read the Iliadic 'inconsistency' in a positive light (i.e., not necessarily as a threat to the unitarian point of view), it brings into relief the kind of innovation that the poet was able to employ. ${ }^{29}$ In my investigation I note a number of places where poetic innovation and/or invention serves to steer the narrative in a specific direction. To cite one example, from Chapter V, the poet of the Hymn to Apollo chooses to depart from the convention, represented by four other versions, by assigning a female gender to the dragon, which enables the narrative to proceed along a carefully calculated path.

\footnotetext{
${ }^{27}$ Willcock (1964) 146 writes that 'where it does seem probable that Homer is inventing is in the detail of the paradeigma itself.

${ }_{28}^{28}$ As I also note, the Hymn adopts the Homeric account of Hephaestus' parentage.

${ }^{29}$ Just as 'the canon' itself is open to innovation: 'there is no reason why canons should be regarded as necessarily, or intrinsically, conservative, since texts can be appropriated for different positions' Martindale (1993) 25.
} 
Homer and Hesiod are heirs to great variations in the epic tradition. As I will demonstrate, it is to be expected that among these traditional stories there existed tales of early strife among the gods over whom Zeus finally achieved overall rule. I suggest that both Homer and Hesiod would have known these tales, and both exploit this material to develop their characters' roles in relation to their poems' central ideas. As Lang rightly points out, ${ }^{30}$ the various episodes or parts of episodes narrating the strife that preceded the Trojan War are not likely to have been invented independently in order to parallel details of the Iliad plot; rather, the divine strife of the Iliad story had its origin in such precedents as appear in the paradeigmata. The oral character of the epic tradition leads one to expect that these stories would be transmuted according to the perspective of each previous story-teller, and that Homer and Hesiod, too, would re-draw the stories from their own perspectives. What is remarkable is that both poets are extraordinarily consistent in their references to these previous stories. The use and modification of these stories are not arbitrary or random, but possess their own design. Particularly in the Iliad, we note that references to divine strife are so complex and so consistent that the poet seems to have in mind a coherent picture of the mythical past. ${ }^{31}$ Bearing this in mind, it is my aim to trace this logic through the epic tradition.

The traditional nature of Homeric epic suggests that we need to apply a broader range of imaginative and hermeneutic skills if we are to increase our ability to 'understand' the stories lying behind and beyond the narrative per se. The so-called 'digressions' and

\footnotetext{
${ }^{30}$ Lang (1983) 151.

${ }^{31}$ Graf (1987) 61.
} 
'paradeigmata' suggest a wealth of underlying pre-Homeric legends which are exploited by 'dynamic selection, combination, modification and revision of the myth'. ${ }^{32}$ Some stories have been designated 'inventions' on the grounds of improbability, inconsistency or 'the lack of other parallel accounts'. ${ }^{33}$ However, as I shall suggest, such stories may be revisions of earlier material. We must realise how many stories and poems we have lost.

For example, the myths associated with Nestor shows how complex was the tradition that preceded Homer. ${ }^{34}$ The individual heroes enjoy their own stores of legendary material, and the poet sometimes refers to stories and details about these heroes which have only incidental reference to the main narrative. Although we do not possess epics about Nestor or Diomedes (for example), we can certainly conceive that such heroic songs existed behind the brief Homeric references.

Another example is pertinent: 'the marriage of Eos and Tithonus is briefly mentioned at Odyssey 5. 1-2, but the details of the story are not revealed by the poet. It is highly probable that Homer knew the details of the love-story, for we find it also in the Homeric Hymn to Aphrodite (218-38), Mimnermus (fr. 4 W, 1 G.-P.) and Sappho (fr. 55 L.-P.). But if the Hymn to Aphrodite or the fragments of Mimnermus or Sappho had not survived, some modern commentators might assume that the story of Eos and Tithonus in the Odyssey was a Homeric invention. The 'accidental' nature of the existence of these parallel accounts suggests that it is problematic to categorise certain stories as Homeric

\footnotetext{
${ }^{32}$ Slatkin (1991) 5 .

${ }^{33}$ Willcock (1964) 141-54; Willcock (1977) 45-9; also Edwards (1991) ad 20. 67-74.

${ }^{34}$ Graf (1993) 63 notes that the epithet of Nestor, $1 \pi \pi \delta \tau \alpha$, suggests that epic poetry existed about the hero, Nestor. Further, he suggests that Nestor's mythical biography (Il. 11. 689-92) is closely connected with that of Heracles. Alden (2000) 74-111 discusses the function of Nestor's speeches, and concludes at
} 
inventions purely because they lack parallel contemporary authority. Again, we must recognise how little we know of the vast range of pre-Homeric stories of gods and men.

A final example: the story of the binding of Zeus (Il. 1. 399), which I examine in Chapter I, has been considered by many scholars to be a Homeric invention. ${ }^{35}$ Although there may be no other reference to this account in Homer or later poets, it can hardly be said with any certainty that 'the gods had never presented a real threat to him'. ${ }^{36}$ I will demonstrate that reminiscences of rebellion and challenge do exist in the Iliad; moreover, references to this divine strife are made at significant moments and with significant relevance to the central concerns of the epic.

By alluding to these stories in the form of digressions, the poet allows his audience to interact with his narrative: to imagine the extensive details and ramifications of the stories, to make comparisons, and to deepen their understanding of the present narrative. These digressions are sometimes very short and lacking in detail, but, however brief the reference, we must assume that the ancient audience would have enjoyed the dynamic resonance between the present narrative and the underlying allusion. It is these digressions which provide us with the imaginative background to the epic and make the narrative more impressive. From this perspective, the techniques of allusion and digression are powerful authorial devices which result in many of the epic's most attractive features. If we look at these stories simply as 'invention' and fail to recognise the vast wealth of pre-existing background material from the epic tradition, we lose much

p.111 that Nestor's speeches are always relevant to their context, offering discreet advice on the best way of proceeding in the circumstances.

Cf. Chapter I, n.1. 
of the persuasive power of the stories and malign the composition's structural integrity. The ancients were only too well aware of this, as is demonstrated by Herodotus' comment on the various stories surrounding Helen: ${ }^{37}$

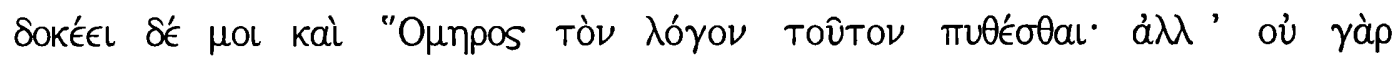

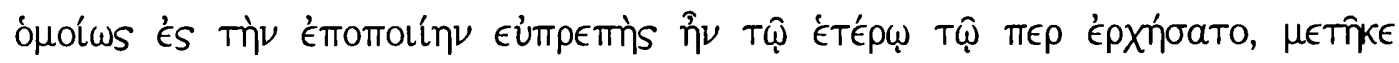

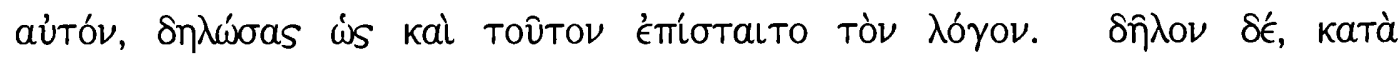

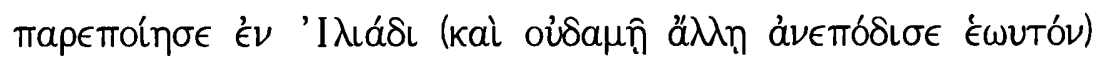

(Histories 2.116)

I think Homer was familiar with the story; for though he rejected it as less suitable for epic poetry than the one he actually used, he left indications that it was not unknown to him. For instance, when he describes the wanderings of Paris in the Iliad (and he has not elsewhere contradicted his account) ... (Tr. A. de Sélincourt)

${ }_{37}^{36}$ Kirk (1985) ad. 1. 399.

${ }^{37}$ See Rutherford (1996) 5-6 on this perennial process of acceptance and variation: Homer was 'an active participant in a tradition which thrives on competition and constant reworking of well-established themes.' 


\section{Chapter I: The Threat of Thetis}

Book one of the Iliad presents a rich and complex mythic environment in which to examine the theme of succession myth. When Achilles asks Thetis to go to Olympus to persuade Zeus, he suggests that she mention her rescue of Zeus from his shackles (1. 399-406). This story has puzzled readers since Zenodotus, who athetised 396406. Modern scholars are also disposed to regard this story as the invention of the poet of the Iliad. ${ }^{1}$ However, even if, to some extent, the poet invented or modified this episode, nevertheless, significant details of the passage can be related to the mythological background that I characterise as 'challenges to the power of Zeus'. ${ }^{2}$ Retracing this lost core story enables us to reclaim and restore the potential logic of this problematic reference for its surrounding narrative.

The importance of Thetis was first signaled by Slatkin. ${ }^{3}$ It is necessary to cover some of the same ground - to take the reader over familiar material in order to lay the basis for Sections 2 and 3, and to indicate points on which my interpretation goes further.

In spite of Achilles' suggestion that she should recount the story, Thetis does not actually do so when she makes her supplication to Zeus (1.503-10; 514-6).

\footnotetext{
${ }^{1}$ For example, Willcock (1964) 141-54; (1977) 41-53; and (1978) ad loc.; Griffin (1980) 185; Kirk (1985) ad loc.

${ }^{2}$ I agree with Lang (1983) 163, who points out that 'whether an Iliad theme attracted old tales as exempla or an old tale inspired an Iliad episode for which the old tale was used as support, each would be liable over time to infiltration of details from the other.' See also Introduction above, pp.17-21.

${ }^{3}$ The Power of Thetis: Allusion and Interpretation in the Iliad, Berkeley and Los Angeles, 1991.
} 
Although various explanations for this omission have been offered, ${ }^{4}$ some new and additional ideas can be added: for example, Thetis' strategy is to truncate the story of Zeus' crisis in order to place increased emphasis on Achilles' mortality; moreover, Thetis' speech seems to imply some hidden relationship between herself and Zeus. As a consequence, a dynamic picture of the succession myth is subtly admitted into the narrative.

In her speech, the underlying image, which functions as a threat to Zeus, is the potential victory of the mightier son over his father. This notion, which is especially important in early Greek poetry (for instance, in Theogony), is reflected not only in book one, but also in other parts of the Iliad. The two-fold aim of this chapter is to discuss, first, how the mythological theme of the 'threat of the son' works in the scene between Zeus and Thetis (Il. 1.493-530); and, secondly, and how the relationship between Achilles and Peleus can be construed within the ambit of succession-myth.

\section{The supplication of Thetis}

Thetis' supplication is of great significance in the Iliad, because its acceptance is the first step in the whole plot of the epic. The poem focuses on Achilles' destiny, and Zeus' decision is paramount to narrative resolution. In narrative terms, Zeus' resolution becomes acceptable to the audience through the persuasiveness of Thetis.

\footnotetext{
${ }^{4}$ For example, Aristotle (E.N. 1124b12-17) explains that Thetis did not tell the story because Zeus, being a god of $\mu \epsilon \gamma a \lambda \circ \psi v \chi i a$, disliked being reminded of the benefit that he received.
} 
Her supplication is a crucial intervention in the war, ${ }^{5}$ and because of its significance we should not be surprised that her speech is so carefully worked out: as Kuch rightly notes, its structure is perfectly composed, a catalyst for progression of the narrative. ${ }^{6}$ The narrative strategy in this supplication is the key to understanding the powerrelations between the characters of Zeus and Thetis. As we will see, Thetis' allusive words recall a past which offered a real threat to Zeus.

The groundwork for Thetis' address is laid with deliberation. Let us consider the beginning of the scene when Achilles calls on Thetis for help. He begins with a remarkable definition of himself:

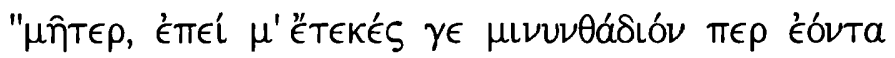

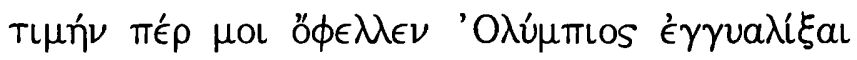

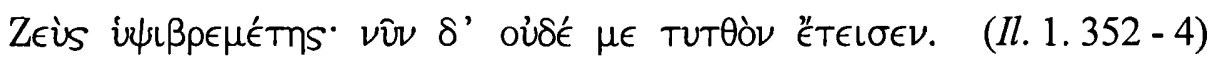

"Mother, since it was you that bore me, if only to a life doomed to shortness, surely honour should have been granted to me by Olympian Zeus, the highthunderer. But now he has shown me not even the slightest honour.

(Tr. M. Hammond)

Since it originated with Zeus, Achilles' destiny - a short life - is the explicit and legitimate rationale behind his appeal for fame: ${ }^{7}$ if Thetis had not been compelled by

\footnotetext{
Slatkin (1991) 53.

${ }^{6}$ Kuch (1993) 204.

${ }^{7}$ Later it becomes clear that Thetis told Achilles of his fate: a choice of either a short but glorious life, or a long life without glory (9.410-16). He also mentions his proposal to leave Troy - which means a long but inglorious life (1.169-71). Here, however, his words suggest that his short life is ordained, and it is not a matter of choice.
} 
Zeus to marry Peleus, her son would not have been 'short-lived'; 8 therefore, had Zeus been his father, Achilles would have been immortal; moreover, by virtue of Thetis' potentiality, he would have been mightier than Zeus. Achilles is owed honour because he is the child of a goddess; but a further connotation is revealed by the special circumstances by which he is the child of this goddess. Finally, Achilles' opening words evoke the latent themes of generational strife and succession myth.

Thetis' reply echoes the first line of Achilles' speech and gains effect from being so placed, with the linguistic parallel reflecting the thematic parallel between the two speeches, and giving heavy emphasis to Achilles' short life and his inevitable destiny:

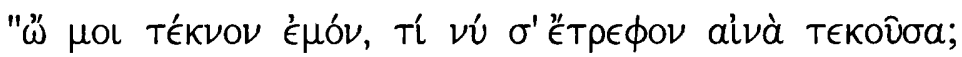

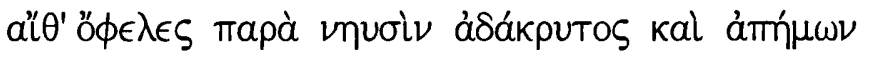

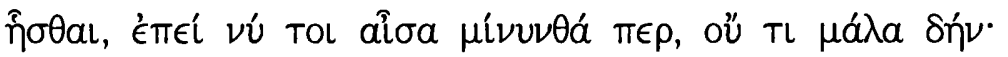

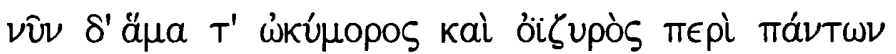

$\ddot{\epsilon} \pi \lambda \epsilon O^{\circ}$

(Il. 1. 414-17)

"Oh my child, what did I rear you for, after the pain of your birth? If only you could sit by your ships without tears or sorrow - because your fate is of short span, not at all long. But now you are both short-lived and miserable as well beyond all others." (Tr. M. Hammond)

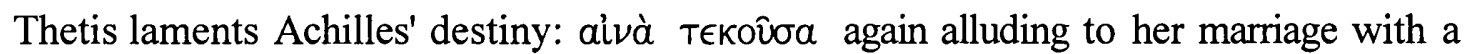
human, begetting a child who is a mortal. She puts emphasis on his short life, wishing that he were now sitting by the ships, without grief and unharmed (415-6). She

\footnotetext{
${ }^{8}$ The marriage of Peleus and Thetis is mentioned by Pindar (I. 8.29-38; Py. 3.87-92; N. 3.32-36; 4.49-67; 5.25-37) and Aeschylus (Pr. 167ff, 515ff, 755ff, 907ff); in Homer it is mentioned only once, and not in detail (18.434). I agree with Griffin (1977) 41, who writes that, 'the poet of the Iliad is
} 
expresses two ideas (Kirk believes these to be contradictory ${ }^{9}$ ), and I conjecture that these are that Achilles could be free from the danger of battle, and live happily. The

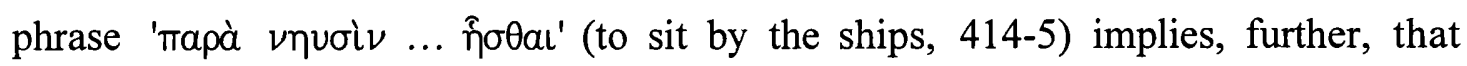
Thetis regrets Achilles' involvement in the Trojan war. Although she accepts that his life is destined to be short (416), it seems that she would prefer him even for this short time to have 'an unharmed, griefless life' that is the preserve of the gods. Her lament once more concerns Achilles' mortality: she alludes to the fact that her son could have been immortal had she not been forced into marriage with a human. The complaints and laments of Thetis and Achilles are thus repeated and interrelated, as Kuch notes: the 'flashback' method (das Mittel der Rückblande) ${ }^{10}$ and repetition escalate the cumulative tension. Some arcane, close connection between Thetis, Achilles and Zeus is implied, and this gradually comes into focus as the theme of succession-myth is evoked.

In Achilles' account of how Thetis once freed Zeus from his shackles (1. 396406), Briareos or Aigaion is of central importance. ${ }^{11}$ On one level, Achilles relates this episode in order to offer grounds for reciprocal benefaction. A more subtle reading exposes the recurrent theme of genealogical stasis:

\footnotetext{
familiar with the story but has suppressed it, preferring unexplained mystery to the monstrousness of metamorphosis and ascription to Thetis of an un-human pixie character. '

${ }_{9}^{9}$ Kirk (1985) ad loc. notes that 'Achilles could hardly be free from grief in such circumstance; had he been griefless, he would have been out there fighting'.

${ }^{10}$ Kuch (1993) 205 also points out that the scene between Thetis and Achilles foreshadows the scene between Thetis and Zeus; and between these two scenes a deliberate use of 'Rückbland' is noticeable.

${ }^{11}$ Regarding the narrative function of Briareos, Slatkin (1991) 69 suggests that he functions as a reminder, multiplying the succession-myth motif.
} 


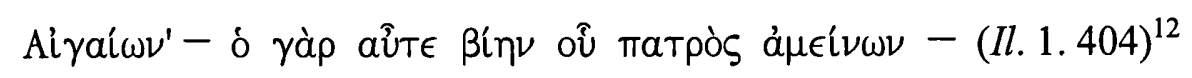

Aigaion. For he is, in turn, mightier than his father (Loeb translation)

The ascription to Achilles of this particular reference emphasises the theme of succession. By mentioning Briareos/Aigaion, Achilles reminds Thetis of the possibility that he himself could have been mightier than Zeus. Even if viewed in the most general terms, this is a veiled threat to Zeus: just as Zeus was mightier than his own father Cronus, so too is Zeus always threatened with the possibility of having a son mightier than himself. In this speech, Achilles implies that he is associated with the ongoing genealogy of Olympus.

Briareos is a typical supporter of Zeus, and is also particularly associated with binding which, as I will argue, is evocative of the succession-myth theme. ${ }^{13}$ In Hesiod's account, Briareos and his brothers Cottus and Gyes were bound and cast beneath the earth by Uranus, and later saved by Zeus and the other gods (Theog. 61727). Zeus learns from Gaia that the side which persuades Briareos and his brothers to join it will be victorious (Theog. 627-8). In order to help Zeus, Briareos and his brothers bind Cronus and the other Titans, and cast them under the earth (Theog. 71318). Thus, Achilles' mention of Briareos is highly allusive: just as Briareos is mightier than his father, so too could Achilles have been mightier than Zeus; just as Briareos

\footnotetext{
${ }^{12}$ I take $\gamma$ áp as emphatic, not explanatory, since 'mightier than his father' does not explain the alternative name of Aigaion, as is generally recognised. Cf. Kirk (1985) ad loc.; Slatkin (1991) 70, $\mathrm{n}$. 17. Leaf (1900) ad loc. comments on a $\hat{\jmath} T \epsilon$ that 'Poseidon, in union with the other gods, was stronger than Zeus, so his son again was stronger than he.' Against Willcock's claim (1964) 147 that this phrase is illogical in the context, I contend that it is a key phrase in the story.

${ }^{13}$ Slatkin (1991) 69.
} 
helped Zeus to bind Cronus, so too could Briareos help Achilles; and just as Briareos saved Zeus at Thetis' request, so too could Briareos help Achilles at Thetis' request, if ever she would make the request; of course this is a sort of moral blackmail, not an actual threat that Thetis can bring Briareos into play. That is, just as Briareos and his brothers were the guarantors or king-makers in the previous struggle for sovereignty, so too might they play a decisive role in another struggle.

In spite of Achilles' suggestion, Thetis does not repeat this story, ${ }^{14}$ but simply remarks:

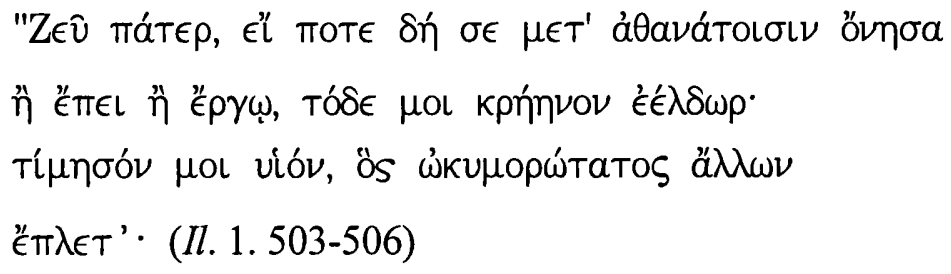

"Father Zeus, if ever I have done you service among the immortals in word or in action, grant this my desire. Show honour to my son, who is short-lived beyond all other men. (Tr. M. Hammond)

Thetis says surprisingly little, which, in itself, is significant: the effect of truncating

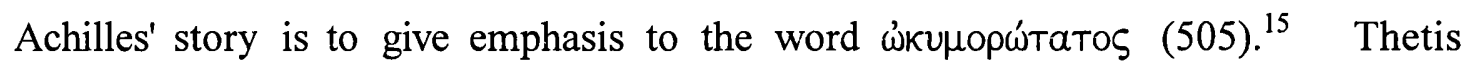
secured Zeus' survival by giving birth to a mortal child. Therefore, by employing this

\footnotetext{
${ }^{14}$ Slatkin (1991) 59 observes that Thetis is one figure who does not refer to her own power, since the rescue of Dionysus (6.130-37) and that of Hephaestus (18.394-98) are narrated by those whom she saved.

${ }_{15}$ Braswell (1971) 19, n.2 holds that Thetis truncates Achilles' story because the audience still has Achilles' speech in mind; but this explanation is unlikely, because there is a well-known example of repetition when Achilles relates the story of Agamemnon and Chryses (1.366-92) to Thetis, even though the audience would certainly remember what had just been previously narrated (1.8-244). Cf. Kirk (1985) 91-3. Willcock (1964) 143 tentatively suggests that Thetis does not think it worth repeating the story because it is sheer invention. But even if it was invented, this would not be a
} 
word, she alludes to the greatest favour she has done Zeus: she did not activate her fatal power by begetting a child mightier than he. As Slatkin argues, Zeus' sovereignty is guaranteed at the cost of Achilles' mortality. ${ }^{16}$ Because her request concerns Achilles' fame, it is much more effective for Thetis to mention his mortality than the story of Zeus' binding. Had the matter only concerned Zeus and Thetis, then Zeus' rescue would have provided sufficient reason for the return of a favour. However, the favour she asks is concerned with Achilles' glory. As a hidden subtext, the story of the marriage between Thetis and Peleus becomes all the more powerful and significant as the justification for her supplication.

Achilles does not appeal to Zeus directly because only Thetis can make this particular appeal. ${ }^{17}$ Having a decisive card to play, and being an immortal herself, she is far more influential than Achilles. Moreover, only Thetis-the-mother can so

satisfactory reason for not repeating it, if to tell the story in detail would serve a persuasive purpose. There would be no reason to suppose that the story would seem fictitious to Thetis or Zeus.

${ }_{11}^{16}$ Slatkin (1991) 101-3 points out that 'the price of Zeus' hegemony is Achilles' death.'

${ }^{17}$ On the question of why Achilles does not appeal directly to Zeus, Leaf (1960), Willcock (1978) and Kirk (1985) offer no comment. Slatkin (1991) 59-61 raises the question without answering it. My view is that it is not an Iliadic way of thinking that gods will always be amenable to the prayers of

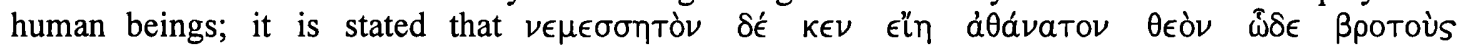
á $\gamma a \pi a \zeta \zeta^{\prime} \mu \epsilon \nu$ ä $\nu T \eta \nu$ (24.463-4), 'it would cause anger in heaven for an immortal god to show affection openly towards mortals'. Accordingly, heroes' prayers are in most cases partly or wholly rejected in the Iliad: the prayer of Agamemnon to Zeus (2.419) is wholly rejected, as is that of Hector to Athena (6.311). Indeed, when Achilles directly prays to Zeus for Patroclus (16. 233-48), his prayer is only partially accepted. Here, however, the acceptance of Achilles' appeal is indispensable for the whole plot of the epic. In order to preclude the wholesale acceptance of a human being's (Achilles) prayer, Thetis, instead of Achilles, makes the appeal. In addition, the importance of supplication must be noted. The supplication of Chryses, the priest of Apollo, was successful (1.37-52). As direct supplication to Zeus would not be allowed in Achilles' case, since he is not a priest of Zeus, he might have asked Thetis to make the appeal. What is significant is that Zeus accepted Thetis' supplication at the cost of Patroclus' life. The fact that Thetis' prayer does not prevent the loss implies, again, that supplication by a mortal is not often accepted, even if supported by an immortal. In terms of the epic's plot - on the macroscopic, cosmic level - the intervention of Thetis is, of course, important for the further development of the strife-in-heaven motif. 
forcibly relate the request to the uncertainty of succession - the ultimate threat to Zeus.

The groundwork which establishes Achilles' mortality is thus laid, and Thetis' supplication begins in earnest. The framework of supplication - invocation, reciprocal appeal, then precise request - is conventional. We notice exactly the same pattern occurring previously in the prayer of Chryses (1.37-42): invocation (37-9), reciprocal appeal (39-40), request (40-2). The parallel structure is pointed: just as Chryses' prayer is accepted by Apollo, so too should Thetis' prayer be accepted by Zeus. Chryses' prayer, as well as having its own significance, thus functions as a preparatory intertext which underscores Thetis' supplication: it offers a precedent for the successful conclusion of her appeal.

Zeus does not answer Thetis at once; there is, as Kirk describes, 'a long and dramatic silence'. ${ }^{18}$ This silence adds tension to the scene, capturing Zeus' hesitance to accept or reject her supplication. Then, Thetis offers her second speech:

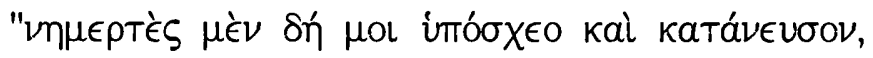

ทे ảmó

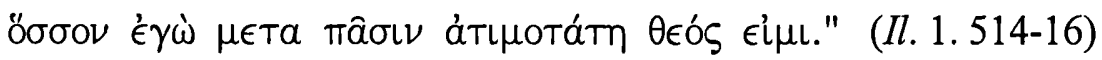

"Promise me now without fail and nod your assent: or else refuse me - you have no cause for fear - so that I can be sure how far I am the lowest in honour among all the gods. "

(Tr. M. Hammond)

\footnotetext{
${ }^{18}$ Kirk (1985) ad loc.
} 
Again the address is brief: she does not cite any deeds beneficial to Zeus, nor give any

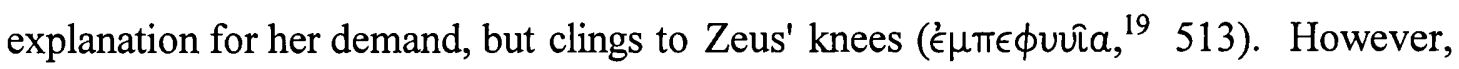

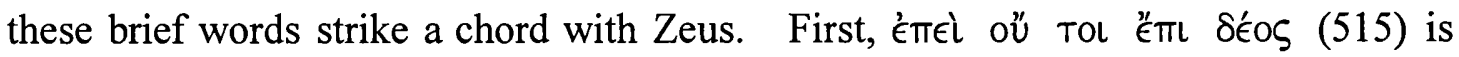
particularly significant. Kirk paraphrases the verse as 'since you can do as you like and need have no fear of anyone', but gives no further comment. ${ }^{20}$ I offer the following interpretation based on implications we have already explored: Zeus knows that Thetis unbound him by summoning Briareos, and Thetis alone is credited with having had such power in the divine realm. ${ }^{21}$ One might paraphrase, 'surely you are almighty, having no cause for fear...? ?22 $^{22}$ The subtext - 'but what I did once, I can do again' - is latently threatening. ${ }^{23}$ This is, again, moral blackmail: Zeus needs to remember how much he owes to Thetis and ought to show xápls, even without any fears prompted by nebulous threats.

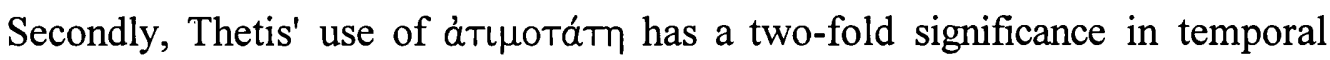
terms. If her present supplication is rejected, dishonour will befall her, just as it did in the past when Zeus refused marriage with her. This single word carries enormous weight: Thetis the mother is twice dishonoured, and her son will never have the

\footnotetext{
${ }^{19} \mathrm{O}$ 'Brien (1993) 89 comments that this word expresses Thetis' intimate dependence on Zeus.

${ }^{20}$ Kirk (1985) ad loc.

${ }^{21}$ Slatkin (1991) 66.

${ }^{22}$ We note a similar phrase at Hy. Aphr. 194 (addressed by Aphrodite to Anchises); Il. 12. 246 (Hector to Polydamas); Od. 5. 347 (Calypso to Odysseus); Od. 8. 563 (Alcinous to the Phaeacians). In these examples, the phrases are literally true, in the sense of consolation or encouragement, because they are employed by a superior to an inferior. However, the case of the present argument (Il. 1. 515) is unique because the phrase is used by one who appears to be an inferior (Thetis) to her apparent superior (Zeus). Thetis is obviously not consoling or praising Zeus: I suggest that the words can be interpreted as Thetis' ingenious way of threatening Zeus with moral blackmail .

${ }^{23}$ Thetis' diction here could be compared with a similar speech of Hera to Zeus (4. 53), where she paradoxically speaks of her beloved three cities, Argos, Sparta and Mycenae; 'Sack these, whenever

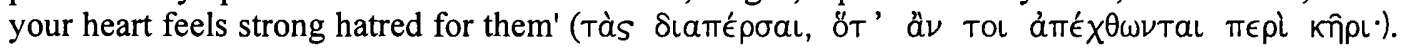




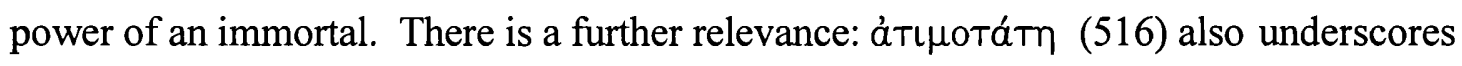

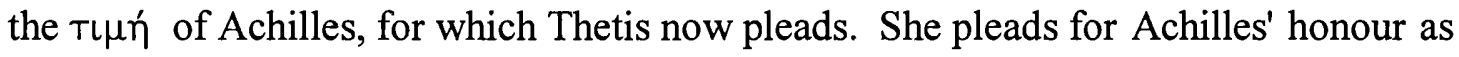
compensation for her own dishonour - her own lost $\tau \iota \mu \eta ́$.

Zeus confirms the underlying import of her threat when he replies by mentioning Hera:

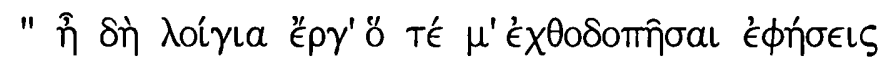

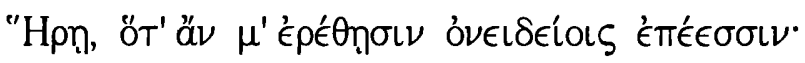

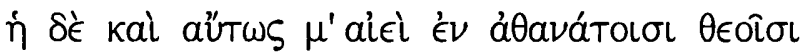

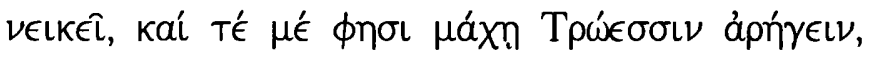

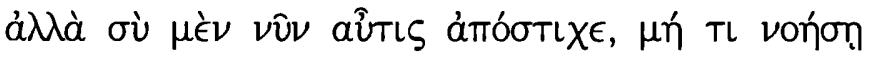

"Hpๆ.

(Il. 1. 518-23)

"This is a grievous business - you will set me at ills with Hera, when she stings me to anger with her taunts. Even without this she is always carping at me among the immortal gods, and saying that I help the Trojans in battle. Well, you must go back now, so that Hera does not see anything.

(Tr. M. Hammond)

Why, at this point, does Zeus mention that he is so afraid of Hera, who might seem irrelevant to Achilles' case? Hera would oppose a plan to help the Trojans, since she wishes for a Greek victory, however, this cannot be the only reason for Zeus' especial concern, because there are other gods as well who would oppose his plan. Rather, the problem seems a domestic one: Thetis' supplication relates to her abortive marriage to Zeus, and his fear of Hera is consequent to that. Hera's taunting words (540-3) confirm that the larger issues of victory and partisanship are not at stake. If we bear 
in mind the undercurrents noted above, we appreciate better the complex relationships between Zeus, Hera and Thetis which form a potent subtext to the Iliadic narrative.

It is the Iliad's narrative strategy to accentuate this problem of genealogical strife. In this particular case, the strife manifests itself in the parallel, successful alliances of mother with son against father. The point of Thetis' claim is that Zeus could have been the father of Achilles: just as Gaia claimed her right to take revenge on the basis of Uranus' outrageous behaviour towards her children, so too does Thetis here claim her right on the basis of Zeus' outrageous decision about her marriage. Thetis offers a reminder to Zeus of Achilles' potentiality which was totally eliminated by Zeus' desire to retain cosmic power. In sum, Achilles and Thetis ask Zeus for compensation for their shared, dishonoured fates.

\section{Generational strife}

There are other examples of this theme of 'generational strife'. Hector's farewell to Andromache and their baby son Astyanax is undoubtedly one of the most moving scenes in the Iliad. As Kirk remarks, 'the description of the baby's fright as his father reaches out to him deserves all its fame, giving a sparkling impression of these intimate events and reactions in simple, traditional language. ${ }^{24}$ On another level, it offers another example of an evolving family hierarchy. Let us consider Hector's prayer: 


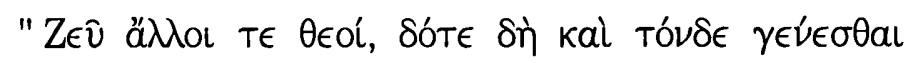

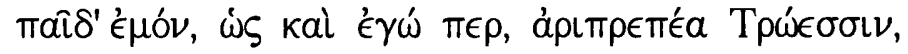

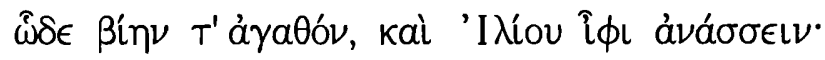

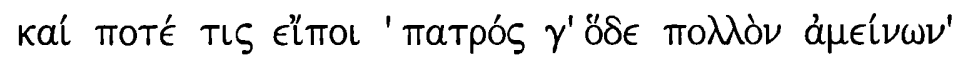

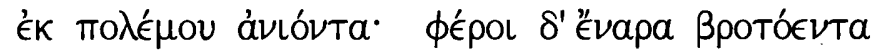

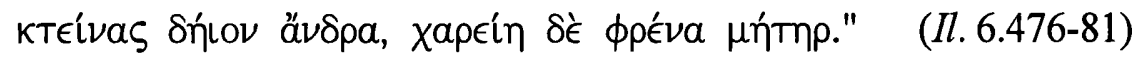

"Zeus and you other gods, grant that this my son may become, as I have been, preeminent among the Trojans, as strong and brave as I, and may he rule in strength over Ilios. And let people say, as he returns from the fighting: 'this man is better by far than his father.' May he carry home the bloody spoils of the enemy he has killed, and bring joy to his mother's heart."

(Tr. M. Hammond)

His prayer appears straightforward: he wishes for his son, like himself, to be preeminent in strength and bravery among the Trojans; and, that his son be famed as mightier than his father. Hector's prayer contains two slightly different ideas: his own wish for his son to be as preeminent among the Trojans as he himself is; and public recognition that his son is preeminent. The prayer conforms to generally held convictions. As de Jong analyses it, ${ }^{25}$ the gulf between Hector's own wish and public opinion would not be a wide one: in fact, despite their different nuances, they overlap. When Hector is facing the prospect of death, the reality of potential father-son conflict cannot be an issue; his wish that his son be better than himself is predicated upon these special circumstances. However, we might consider that the diction of his speech evokes the pattern of inter-generational conflict that pervades the Iliad.

${ }^{24}$ Kirk (1990) ad 6.460-70. 
The story told by Phoenix (Il. 9.447-461) is a more telling appearance of the motif of 'generational strife'. An intriguing aspect of this story is the mother's role.

Phoenix enters into conflict with his father for the sake of his mother:

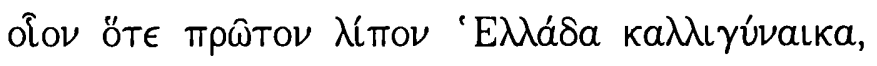

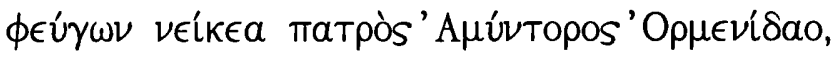

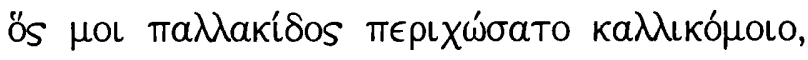

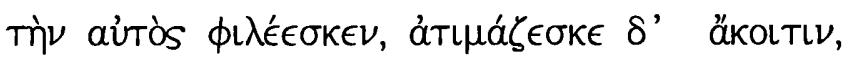

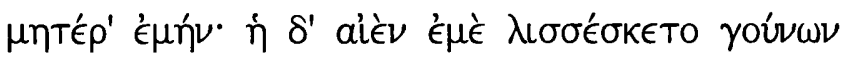

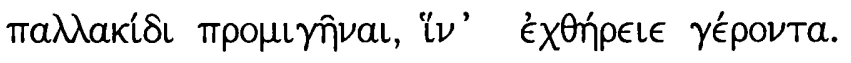

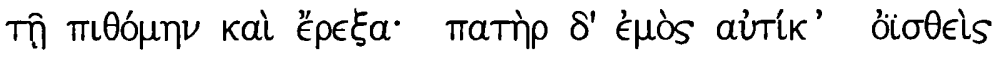

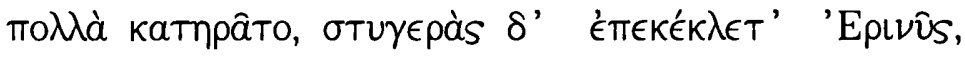

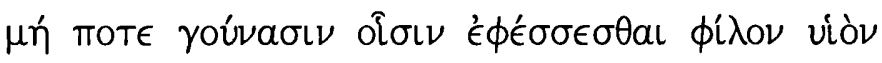

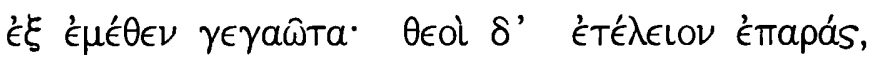

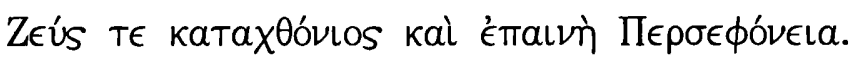

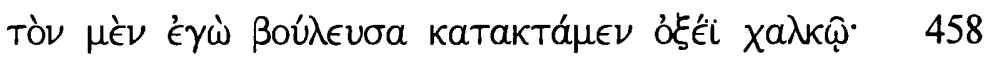

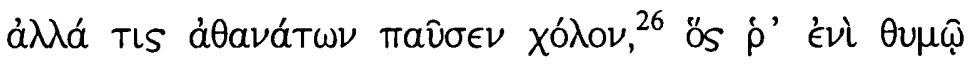

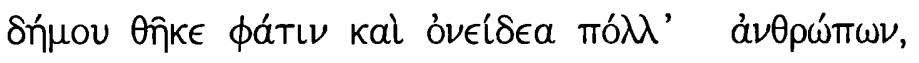

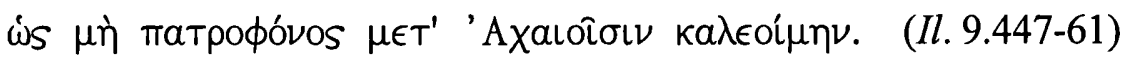

..., as I was when I first left Hellas where the women are handsome, running from the anger of my father Amyntor, son of Ormenos. He was enraged at me over his lovely-haired concubine. He was giving his love to her and scorning his wife, my mother: and my mother constantly took me by the knees and entreated me to lie with the concubine first, to made her hate the old man. I agreed and did it. And my father realised at once and heaped curses on me, calling up the hateful Erinyes, that he should never sit on his knees a dear son born to me: and his curses were given fulfilment by the gods, Zeus of the underworld and terrible Persephone. My thought was to kill him with the sharp bronze. But one of the immortals stopped my fury, putting in my mind the talk of my people and all the shaming things that men would say, so that I

\footnotetext{
${ }^{25}$ De Jong (1987) 83 discusses that in such 'potential tis-speech', the fictitious speaker (tis) is used to give expression to the inner voice of the real speaker. See Od. 6.244

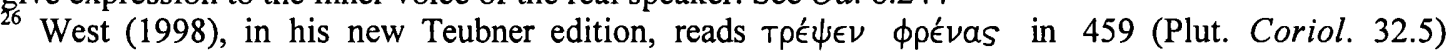

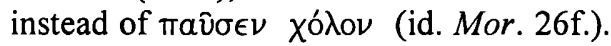


would not have the name of parricide among the Achaians.

(Tr. M. Hammond)

The omission of explanatory details serves to render the narrative of this story rather inconsequential. $^{27}$ The main line of the story is: Phoenix's father, Amyntor, brings home a concubine; Phoenix is persuaded by his mother to seduce the concubine; when his father finds out, he curses his son with childlessness; ${ }^{28}$ as a result, Phoenix plans to kill him. The last part of this passage (458-61) is missing from the manuscripts and scholia, but it is hardly surprising that Phoenix planned to kill his father. ${ }^{29}$ Various interpretations of the story have been proposed, ${ }^{30}$ but I note only two valuable points suggested by Alden: first, the story makes Achilles identify with Phoenix, for both have quarrelled with a superior about a woman; secondly, the story implies unpleasant consequences if Achilles persists with his quarrel. ${ }^{31}$ However, I suggest that the story of Phoenix has two further functions: first, it shows, on a broader scale,

\footnotetext{
${ }^{27}$ Hainsworth (1993) ad loc.

${ }^{28}$ Devereux (1973) 43-4 argues that castration and blinding are regular alternative punishments for sexual transgression in Greek mythology.

${ }^{29}$ The passage is cited only by Plutarch, who states that Aristarchus removed these verses 'from fear'

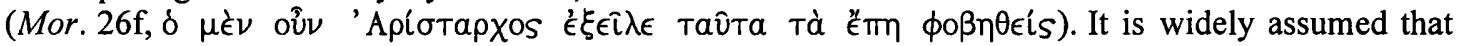
the verses are genuine, although Aristarchus (or more probably, an earlier transmitter of the Homeric text) omitted them. Janko (1992) 28, followed by Hainsworth (1993) ad loc., comments that 'the lines... are Homeric in style and language'. Griffin (1995) ad loc. writes that v. 460 does not look Iliadic, and considers the possibility that the verses are not original, but derive from a marginal note by some learned reader. It may have seemed to later editors to be an immoral action for Achilles' preceptor.

${ }^{30}$ Since the precise description in the following passage (462-77) seems to reflect ancient custom, I do not agree with van der Valk (1963) 484, who suggests that Homer invents a quarrel between Phoenix and his father in order to give a reason for his taking refuge with Peleus. For the history of the discussion see Scodel (1982a) 128, nn. 1 and 3. I do not agree with Scodel (1982a) 133-6 who argues that this is a negative paradigm: in order to persuade Achilles to remain, Phoenix at first suggests that his own departure was an appropriate event. This would seem too sophisticated and complicated an explanation.

Alden (2000) 21 cites this story as an example of 'para-narratives' which make some internal reference to the events of the main narrative.
} 
the story-pattern of generational strife in which mother and son co-operate in protest against husband and father; secondly, it offers a new presentation of Peleus (see the next section of this chapter). Phoenix contrived to help his mother and, at the same time, to overcome his father. Just as Gaia plays the decisive role in the major succession-myth, here, too, another mother catalyses this generational strife: she knew what to do, she persuaded her son, and Phoenix followed her instructions. Mothers can be regarded as dangerous because they establish a close relationship with their sons, who, being young and vigorous, are capable of overcoming their fathers. ${ }^{32}$ As

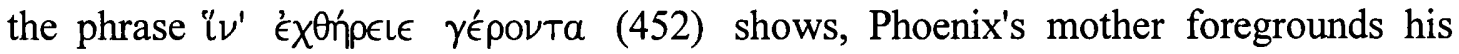
youth and superior vigour. In spite of the fact that the problem was originally between husband and wife, once the son intervenes, it shifts to a conflict between father and son (and, there is no further mention of the mother after she successfully persuades Phoenix). The mother is dangerous, but the real threat to the father comes, eventually, from his own son.

The Odyssey, too, presents us with an example of the potential danger in the relationship between father and son. Let us examine the problematic speech of Telemachus in the scene of the bow-contest:

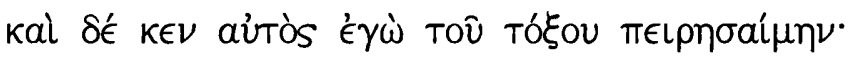

\footnotetext{
${ }^{32}$ Slater (1968) 132 notes the fear of the mother's procreative power in the myth of revolt. He points out that mature and maternal women are particularly feared by the ancient Greeks, and sometimes are regarded as the most dangerous. Slater (1968) 12: in tragedy it is young women and virginal goddesses who are helpful and benign, and that most often the household is "mother-dominant and father-avoidant". Caldwell (1989) 161 offers an interesting perspective on the relationship between the mother and the son in generational myth: 'the lesson Kronos has learned from the fate of Ouranos is
} 


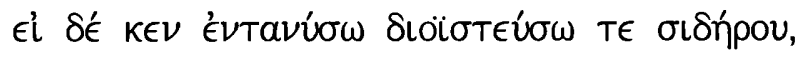

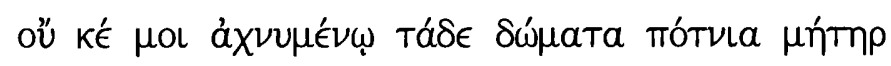

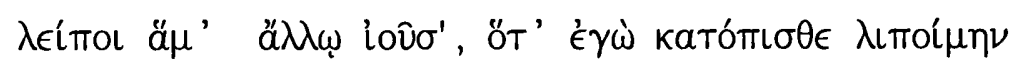

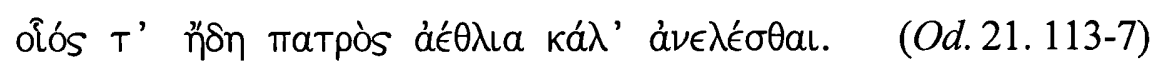

And I myself should be glad to make trial of the bow. Perhaps I may string it and shoot clean through the iron; then I should not grieve to see my mother forsake this house in another's company, if I myself remained behind with prowess enough to take upon me such feats of mastery as my father's.

(Tr. W. Shewring)

And I would like to try with this bow myself. If I tauten it and shoot through the iron, my lady mother would not, to my sorrow, leave this house, going with someone else, when I should be left behind already able to take off my father's fine prizes. ${ }^{33}$ (Tr. R.D. Dawe)

When Telemachus offers the contest to the suitors, he announces that he will try the bow first. As the rightful heir to the household, he needs here to show the authority and strength of character which he lacked in the assembly scene of Book 2. 35-256. ${ }^{34}$

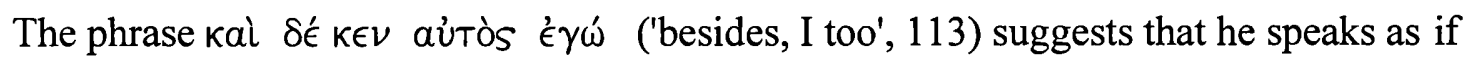
a sudden thought has struck him; ${ }^{35}$ but the role in which he casts himself seems illjudged, occurring as it does in such a critical situation. The repeated mention of weeping and lament action emphasises the moment's impact: when Penelope draws

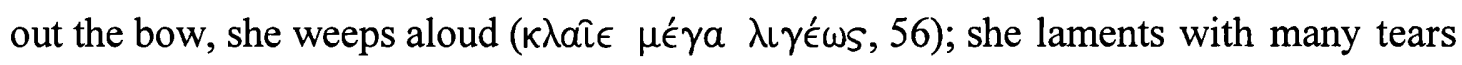

basically misogynistic: he sees that it is the woman as much as the son who is his enemy. His children must be kept separate from their mother'. Cf. Chapter IV, Section 2 and 3.

${ }^{33}$ Dawe (1993) ad loc comments that 'the only prize at stake is Penelope herself. He doubts the authenticity of the line 117, saying that the line is 'a vaunt which has strayed in from some rival version, in which the "prizes" were the iron and bronze'.

${ }^{34}$ Rutherford (1992) 26. De Jong (2001) ad 21. 101-39 comments that the scene offers a different significance for the Suitors as opposed to the narratees: for the Suitors, Telemachus plays the role of a weak and helpless youngster, but for the narratees, he shows his real strength by setting up the axes 


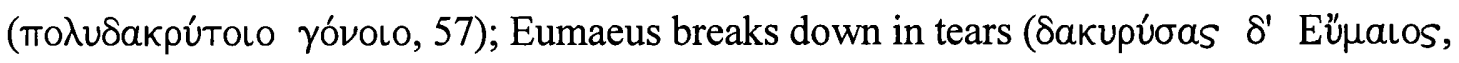

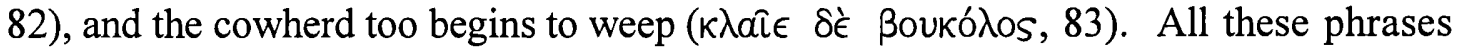
indicate that the time has finally come for Penelope to leave the house. In such a desperate situation, why has Telemachus taken it upon himself to act in this way? It appears as if Telemachus becomes one of the suitors in the contest for Penelope. The introductory words of Telemachos' speech all the more intensify his curious state of

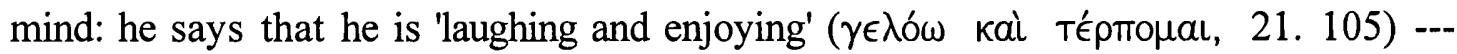
certainly an unusual reaction to this sorrowful and critical moment.

Much discussion has centred on the interpretation of the following, difficult verses (115-7). Telemachus uses two optatives, $\lambda \epsilon i$ mol and $\lambda\llcorner\pi \circ i \mu \eta \nu$, at the beginning and end of line 116 . The use of this mood stresses the uncertainty of the moment, and causes us to wonder about Telemachus' intentions. Interpretations of these verses are twofold, depending on whether one takes oủ (115) with $\mu$ o

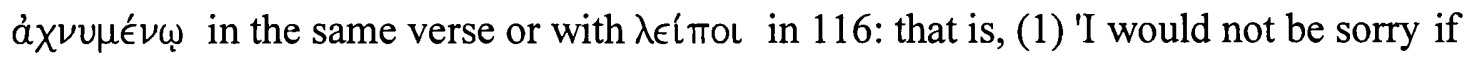
my mother were to leave, so long as I should remain here' (or 'while I were left behind', that is, if once Telemachus can prove he is as good as his father by using the bow, then he will not care if Penelope departs); ${ }^{36}$ or, (2) 'she will not have to leave to my sorrow as long as I remain'; that is, by winning the contest he will retain his mother as

well. I agree with de Jong, but I am reluctant to accept her suggestion that 'Telemachus purposely failed to string the bow.'

${ }^{35}$ Hayman (1882) ad loc.

${ }^{36}$ Hayman (1882) ad loc.; Monro (1901) ad loc.; Ameis, Hentze and Cauer (1925) ad loc.; Stanford (1948) ad loc.; Russo, Fernandez-Galiano and Heubeck (1992) ad loc. 
the prize.${ }^{37}$ Stanford shows a degree of uncertainty and comments that he 'diffidently' prefers the former. ${ }^{38}$ The cogency of these two interpretations rests on one's rendering of $\dot{d}^{\prime} \theta \lambda_{\iota} a$ (117). Those who prefer the former interpretation take the word as 'the contests' (Monro) ${ }^{39}$ or 'the weapons' (Hayman); Russo et al. offer no comment on ảé $\theta \lambda \iota$.

There is little doubt that the word $\ddot{\alpha} \in \theta \lambda o v$ can designate Penelope, since it is announced, by her, that the prize in this contest is herself:

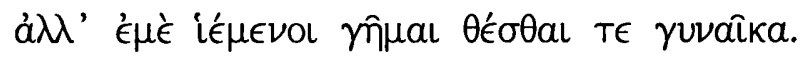

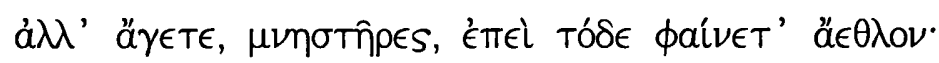

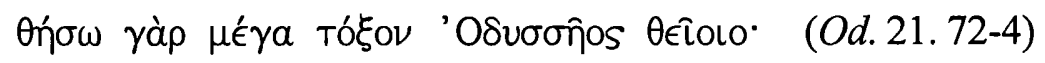

...the desire to have me as wedded wife. Well, my suitors, the prize at stake is now displayed for you. I will put before you the great bow of King Odysseus. (Tr. W. Shewring)

...but [you] always pressing to marry me and make me your wife. So, come, suitors, now that the prize is here to be seen: I shall place the great bow of divine Odysseus: (Tr. R.D. Dawe)

She describes herself as ă $\in \theta \lambda o \nu$, 'Come, suitors, now that the prize is here to be seen' (73, tr. R.D. Dawe). Telemachos repeats her use of ä $\epsilon \theta \lambda o \nu$ at 106 :

\footnotetext{
${ }^{37}$ Van Leeuwen (1917) ad loc.; For Dawe's interpretation, cf. n. 33 above. The difficulty of this

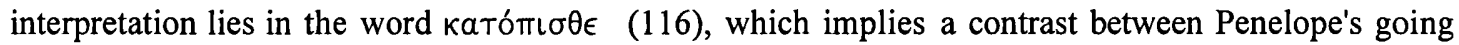
and Telemachos' staying behind. However, the word could have temporal significance, meaning that 'I remain hereafter'.

${ }_{38}^{38}$ Stanford (1948) ad loc.

${ }^{39}$ Both ä $\in \theta \lambda o \nu$ and $\ddot{a} \in \theta \lambda เ o \nu$ could mean 'the contests' in their plural forms, such as at Od. 24. 89; Od. 24. 168-9. However, at $O d .21 .73, a ̆ \in \theta \lambda o v$ is used in the singular, and the combination with
} 


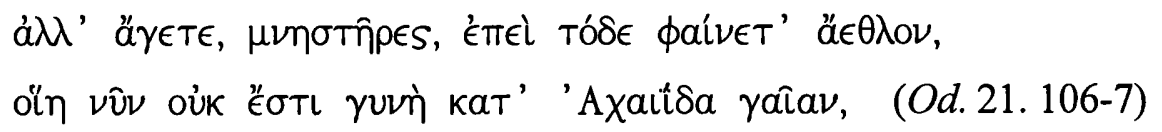

But come, suitors, since this prize is here to be seen, a woman whose like is not now to be found in the Achaean land... (Tr. R.D. Dawe)

Telemachos confirms that Penelope is the prize. But at 117 , he uses a different word, $\dot{a}^{\prime} \in \lambda \iota a$, for what he hopes to accomplish.

Interpretations of these words are, again, twofold: the first takes $a \theta \theta \lambda \mathrm{o \nu}$ (73, 106) and déf $\theta \lambda_{\iota a}$ (117) to convey a similar significance; the second reads them with different meanings. If the former holds true, one plausible reading of verse 117 is 'I would (hereafter) be able to take up my father's glorious prize, Penelope.' This reading might offer a better understanding of Telemachus' conspicuous excitement during the efficient preparations which so amazes the suitors (118-23). Then Telemachus declares that he will try the bow in order to remain in the house, to take Penelope and the kingship of Ithaca. ${ }^{40}$

If we follow the latter interpretation, the difference in meaning between the

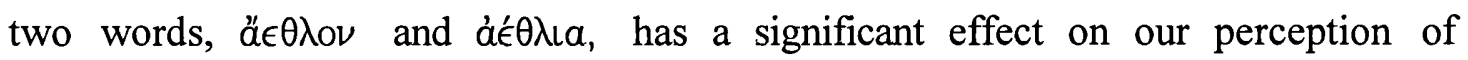
Telemachos' characterisation. Although both Penelope and Telemachos recognise that the prize of the bow-contest is Penelope, Telemachos now changes the word to

the verb $\phi a i \nu_{\epsilon} T^{\prime}$ strongly suggests that $a \in \theta \lambda$ o $\nu$ means the prize of the contest, which can be construed as Penelope.

${ }^{40}$ Finkelberg (1991) 306 and 315 argues that kingship in heroic Greece is characteristically transmitted by marriage to the royal heiress, and that this is the reason why Telemachus not only cannot assume the position of his missing and presumably dead father, but cannot even entertain the idea of the contest. My interpretation of this passage demonstrates how critical and dangerous the situation becomes when Telemachus almost commits himself to incest. However, for an ancient audience, 
$d^{\prime} \epsilon^{\prime} \lambda_{\iota} a$ at 117 , implying that he will join the contest not for Penelope, but for the 'prizes', 'combat rear' or 'weapons'. By this change, his intention is made ambiguous; and significantly, the notion of incest is avoided. In the Oedipus story, as is told in 11. 271-80, the emphasis is on Epicaste's ignorance (and, by implication, the ignorance of Oedipus, 272-3), the $\alpha \lambda \gamma \gamma \in \alpha$ of Oedipus $(275,279)$ and the suicide of Epicaste (277-8). Although Oedipus' deed is not denounced explicitly, the Odyssey certainly casts incest in a negative light. Similarly, in the passage under discussion, Telemachos would not countenance marriage with his mother: for this reason, the word déf might be tactfully exchanged for ă $\epsilon \theta \lambda \mathrm{\nu}$.

This latter interpretation suits Telemachos' decent character. However, if we think about story patterns in more general terms, the motif of son competing with his father --- in this case, for his father's wife --- could be applied also to this passage. That is, at the very least, we might suggest that the potential for competition between father and son (implied in the contest) is intensified by these ambiguous, contextual hints.

Of course, Telemachos fails even to string the bow.

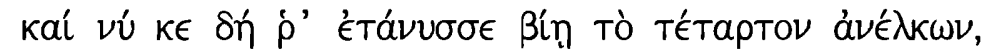

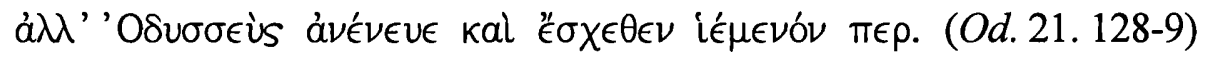

Then a fourth time he strained at it, and this time he would indeed have strung it, but Odysseus gave him a warning nod and stopped him short in his eagerness. (Tr. W. Shewring)

acquainted with the story of Oedipus, the motif of the marriage between mother and son would have been less surprising. 
Telemachus would have succeeded in stringing the bow, had not Odysseus intervened with a nod of warning. It is significant that Odysseus does not stop Telemachus initially (to Odysseus, perhaps Telemachus is the one whom he would least expect to win the contest?), and only intervenes when he almost succeeds. It is significant that it is Odysseus himself who stops Telemachus. It could have been the suitors who stopped him: this would be more predictable in a situation where he is their competitor. After all, in this plot, Odysseus is only beggar and spectator. The suitors have good reason for stopping him, but so, of course, has Odysseus. Why, then, did he not stop Telemachus when he first announced that he would try the bow? What is at stake should Telemachus win? The delay serves a three-fold function: first, the narrative function of provoking suspense; second, the demonstration that Telemachus is deemed worthy enough by his father to pose a potential threat; finally, it could even presage an ironic situation in which Telemachus, as the successful son, wins for his prize Penelope, his own mother. However, of primary importance in this scene is an insidious growth of tension between father and son, and we see that the mounting crisis between the suitors and Odysseus is paralleled in a similar friction between son and father.

According to the Telegony, Odysseus was unwittingly killed by his own son Telegonus, just as Laius was by Oedipus. An additional point of great interest is that Telegonus marries Penelope, and Telemachus marries Circe. This reveals a curious double relationship: two sons of Odysseus marry two partners of Odysseus. The 
same pattern detailed in cosmic succession myth appears here twice: by eliminating the father, the mothers and sons survive. Generational strife (son overcoming father) is a conspicuous theme in Greek myth; it is characterised by a father's fear of falling to his mightier son, and it constitutes a basic element in many Greek stories. The story of Odysseus, like that of Oedipus, is at the very heart of this tradition.

\section{Peleus and Achilles}

When Hera mentions the marriage of Peleus and Thetis in book 24 of the Iliad, she says that she herself raised Thetis:

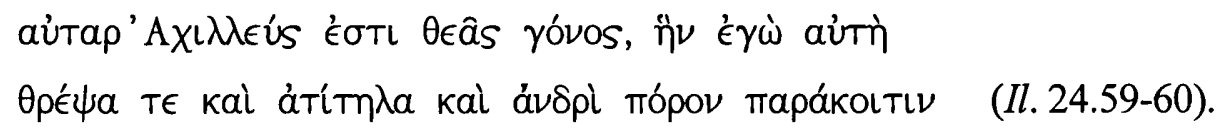

But Achilles is a child of a goddess, whom I myself brought up and reared and gave as wife to a man. (Tr. M. Hammond)

Recalling Hera's suspicious attitude to Thetis in Book 1, Braswell suggests that the story of Hera's upbringing of Thetis is an invention for this occasion. ${ }^{41}$ Braswell's interpretation is supported by Macleod, Willcock, Kirk and Richardson; ${ }^{42}$ however, from the perspective of succession-myth, Thetis' upbringing is of major significance to the narrative. As various episodes in the Iliad demonstrate, Hera is the goddess who

\footnotetext{
${ }^{41}$ Braswell (1971) 23 notes the seeming inconsistency between Hera's attitude to Thetis in Books 1 and 24. However, inconsistency is not a wholly satisfactory reason for postulating invention (as was stated in my Introduction). The poet could certainly allude to different existing stories on diverse, appropriate occasions. For example, Hephaestus' lameness is caused by Zeus at Il. 1.591 and by Hera at $I l$. 18. 395-6.
} 
persistently opposes the power of Zeus. Hera's favour towards Thetis is consonant with her interest in Thetis' potentiality, since she hoped that Thetis' son might overthrow the power of Zeus. Rather than an invention per se, the story of the upbringing of Thetis is better located in the echelons of succession-myth on which I have elaborated. ${ }^{43}$

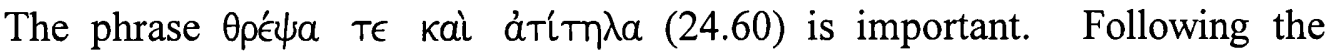
scholia, Willcock notes that these words signify that Hera nursed Thetis as a -small child: ${ }^{44}$

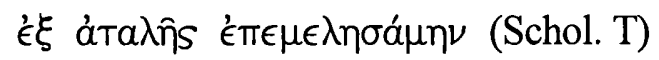

I took care of her from when she was a tender child. (My translation)

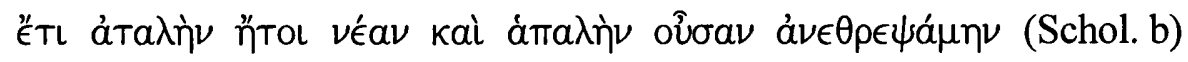

I brought her up who was still a tender and soft child. (My translation)

As both scholia explain, the connotation of a $\operatorname{ti} \tau \eta \lambda \lambda a$ is not only to bring up but also to cherish the baby gently. This implies that Hera had a keen interest in lavishing special care and attention on Thetis. Moreover, the phrase has a particular interest, since the same two verbs recur in another important passage, Theogony 480 (Gaia nourishes and raises Zeus):

\footnotetext{
${ }^{42}$ Macleod (1982) ad loc.; Willcock (1984) ad loc. comments that there is no background concerning Thetis' upbringing; Richardson (1993) ad loc. refers to Braswell with no comment.

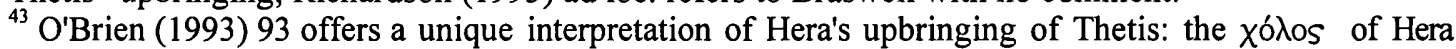
was physically transmitted through Thetis to her infant son Achilles. If $\chi$ ódos could be transmitted by upbringing, as O'Brien suggests, the Xódos of Oceanus and Tethys (14.306) would also have been transmitted to Hera, although there is nothing in the story as told by Hera to suggest that Oceanus and Tethys were angry with one another when they were rearing her. At $I l .14 .303$, we have the same

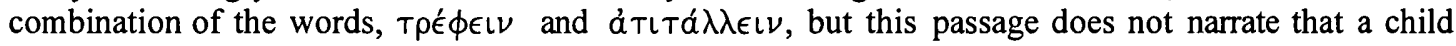
(Hera) is brought up as a challenger. Cf. Janko (1992) ad 14. 306.
} 


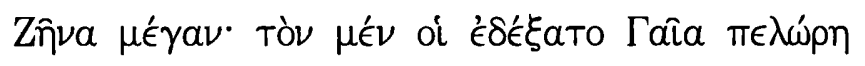

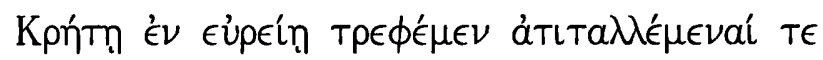

(Theog. 479-80)

...great Zeus. Mighty Earth accepted him from her to rear and nurture in broad Crete. (Tr. M.L. West)

In the Theogony, Gaia received Zeus from Rhea, nurturing him for the purpose of his ultimate de-throning of Cronus (468-74). I propose that, at Theogony 480, these two, verbs signify the nurture of potential challengers to paternal sovereignty ${ }^{45}$ Therefore, in the context of Iliad 24, the subtext of Hera's raising of Thetis provides another marker of Hera's veiled intention: it also provides another important reference which ought to be added to our core of traditional material concerning succession-myth.

A fragment of the Cypria, paralleled in Hesiod (Kyp. fr. 2 PEG and Hes. fr. $210 \mathrm{M}-\mathrm{W}$ ), offers a truncated version of the story of the marriage between Thetis and Zeus:

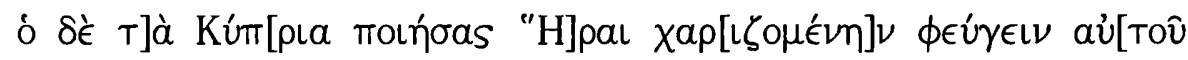

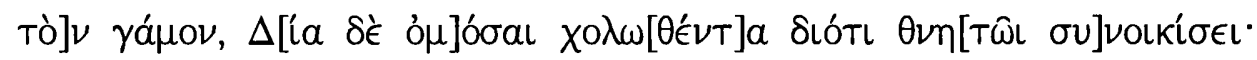

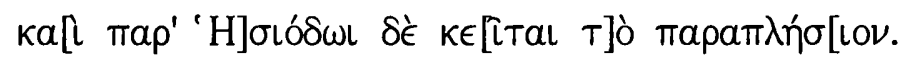

(Kyp. fr. $2 P E G$ and Hes. fr. $210 \mathrm{M}-\mathrm{W}$ )

\footnotetext{
${ }^{44}$ Willcock (1984) ad loc.

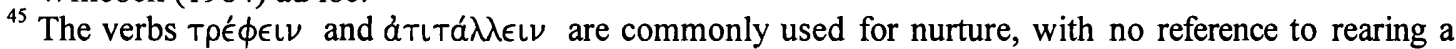
possible challenger, as in Il. 2. 548; 5. 271; Od. 7. 12; Od. 19. 354; Hy. Aphr. 115. However, in some passages we have examples where the word $\tau \rho \epsilon ́ \phi \epsilon l \nu$ clearly denotes rearing a possible

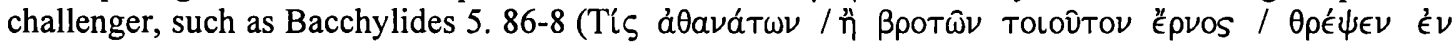

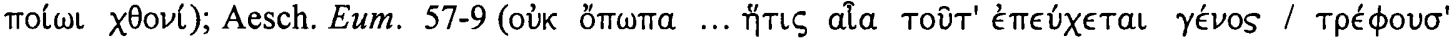

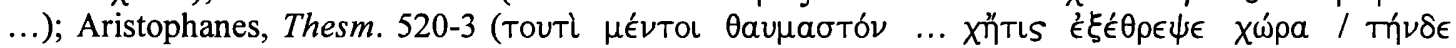

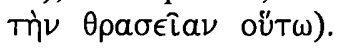


The author of the Cypria says that Thetis, as a favour to Hera, refused marriage with Zeus; he was angry and swore that she would marry a mortal. A similar story is found in Hesiod. (My translation)

It is significant that this account makes no mention of Themis or Prometheus, but

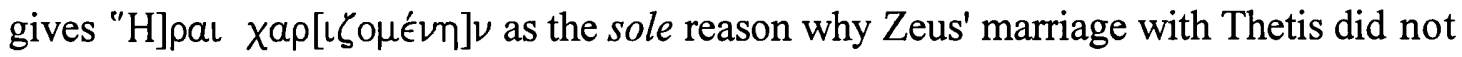
proceed. I contend that the "favour to Hera" alludes to the story of Thetis' upbringing by Hera.

This account raises several issues. First, why should the unwillingness of Thetis (because she wished to do Hera a favour) be the real reason why the marriage was prevented? Had Zeus truly desired to marry Thetis, would not her willingness or unwillingness have been irrelevant for the almighty Zeus? ${ }^{46}$ Indeed, the circumstances surrounding the marriage of Peleus and Thetis demonstrate that her rejection of the marriage is not considered an issue, nor was it the reason why it was prevented. ${ }^{47}$ Secondly, one might expect that it would be Hera who raised an objection to their marriage - for Hera's primary role in Greek myth is that of the 'jealous wife' harassing the unwilling lovers of Zeus. ${ }^{48}$ On the contrary, Hera keeps silent, raising no objections.

\footnotetext{
${ }^{46}$ Theogony 886-929 gives a list of the unions between Zeus and goddesses, some of which openly imply Zeus' compulsion. In other versions, his relations with Metis, Nemesis, Europa, Io and Leda involve deception and/or force. In addition, he allows Peleus to subdue Thetis, and Hades to snatch Persephone at Hy. Dem. 3.

${ }^{47}$ The story of Nemesis (Athen. 334 B and Kyp. fr. 9 PEG) supports my argument: Nemesis transforms herself to avoid marriage with Zeus. The motif of unwilling marriage and transformation is similar to Thetis' story: in both cases they mate under compulsion.

${ }^{48}$ Gantz (1993) 61.
} 
Admittedly, this is a truncated version of the story, with few details: but to clarify the matter, let us turn to the version in Apollonius Rhodius (4.790-804), which supplies further illumination:

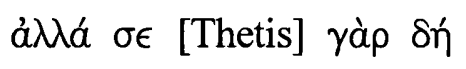

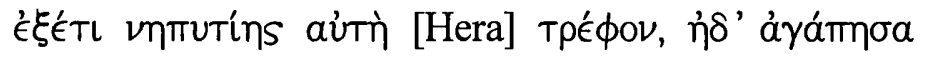

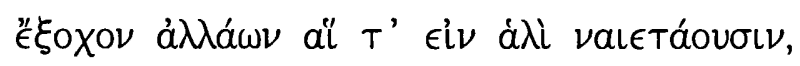

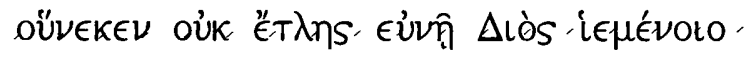

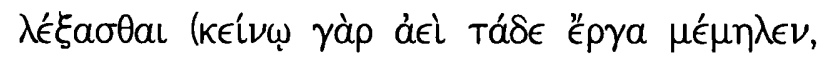

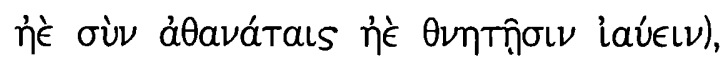

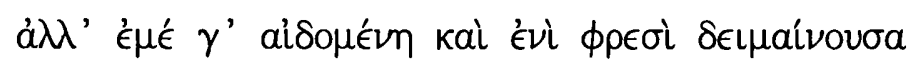

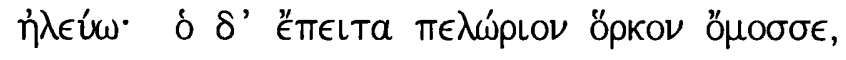

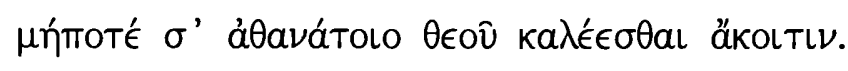

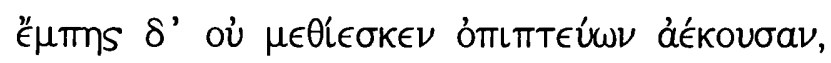

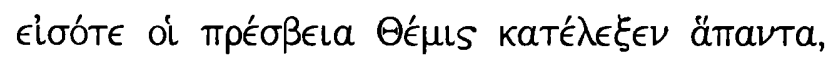

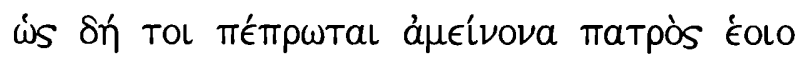

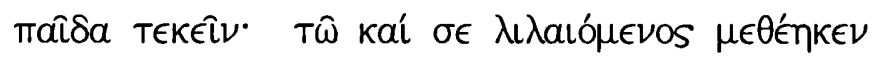

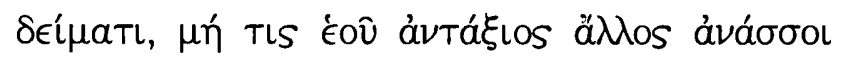

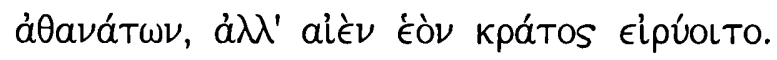

(Argonautica, 4.790-804)

Come - ever since you [Thetis] were a baby I [Hera] have brought you up and cherished you beyond all other goddesses who dwell in the sea, because you were not wanton enough to lie in Zeus' bed though he desired you -his mind is always on such things, whether it be immortals or mortals he wants to sleep with! - but out of respect for me and because your heart was afraid, you rejected him. He then swore a mighty oath that no immortal god would ever call you his wife. Despite this, and though you were unwilling, he kept his eyes on you, until the revered Themis told him in detail how you were fated to bear a son greater than his father; though he was still keen, he left you alone out of fear that some rival would rule over the immortals and so that he could preserve his power for ever. (Tr. R. Hunter) 
Apollonius, too, narrates that Hera raised Thetis from a baby, and loved her (791). Two reasons are offered as to why the marriage between Zeus and Thetis did not occur: (a) Thetis first refused the marriage, as a favour to Hera (796); (b) Zeus, fearing that Thetis might bear a son mightier than himself, subsequently reneged because of Themis' prophecy (800-2). These two reasons are interrelated and, as such, highlight the same message - that of Thetis' potentiality: Thetis was favourably disposed towards Hera who had raised her; Hera, in the knowledge that Thetis could bear a son mightier than his father, reared her willingly. For this reason, Zeus refused the marriage. We discover that Hera's strategy was to create a god, since she herself was incapable of bearing a son mightier than Zeus: and even if this son was born from another goddess, he would at least be capable of usurping the Olympian.

In Apollonius' account, Hera's rhetoric is shrewd, as Hunter points out. ${ }^{49}$ According to Hera, although Thetis refused marriage with Zeus, he did not stop attempting to seduce her against her will, until Themis announced the prophecy (799800). Hera's speech makes clear that Themis' prophecy was the true reason for the marriage's prevention, seeing as Thetis' private emotions meant nothing to Zeus prior to it. ${ }^{50}$

Apollodorus (3.13.5) gives three explanations for the abortive marriage: (a) Zeus (and Poseidon) withdrew as a result of Themis' prophecy; (b) Prometheus declared that the son born to Zeus by Thetis would be lord of heaven; (c) Thetis

\footnotetext{
${ }^{49}$ Hunter (1993) 97.

${ }^{50}$ Green (1997) 327; Hunter (1993) 100 remarks that this scene is a powerful manifestation of the gulf between frightened anger [of Zeus and of Hera] and silent suffering [of Thetis].
} 
would not marry Zeus because she had been brought up by Hera. We see that Apollodorus differs from Apollonius Rhodius only by adding Prometheus' prophecy: $:^{51}$

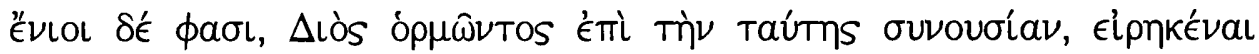

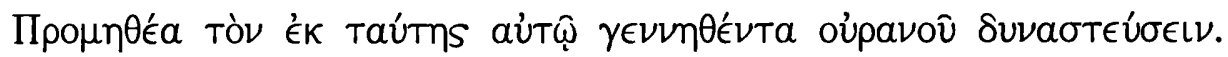

(Biblio. 3.13.5)

But some say that when Zeus was bent on gratifying his passion for her, Prometheus declared that the son borne to him by her would be lord of heaven. (Tr. J.G. Frazer)

These examples demonstrate that the story of Thetis' upbringing is associated with her potential marriage to Zeus; both accounts are closely related, and the common denominator is Hera's scheme to usurp Zeus' sovereignty: Hera's hatred of Zeus would lead her to raise Thetis in order that the sea-goddess might marry Zeus and have a son mightier than he. ${ }^{52}$ Although the Cypria, Apollonius Rhodius and Apollodorus offer Thetis' objections as the reason why the marriage did not take place, another alternative lies in the prophecies of Themis or Prometheus. ${ }^{53}$ Of course, Hera's plan for the marriage was ultimately unsuccessful, since Zeus was informed of the prophecy. However, had he not been informed, Thetis could have served Hera by marrying him. We may conclude, therefore, that although Cypria and

\footnotetext{
${ }^{51}$ Apollodorus probably took the story from Aeschylean Prometheus plays.

${ }^{52}$ The traditional role of Hera is, of course, the jealous wife who prevents and puts obstacles in the way of Zeus' various love affairs (as was mentioned earlier in this chapter). Nevertheless, so great is her hatred of Zeus that, in spite of the implications it might hold for herself, she might risk promoting such an affair if it resulted in his downfall. Compare her great hatred of Troy in Il. 4. 20-49.

${ }^{53}$ The identification of Themis and Prometheus could be traditional. Gantz (1993) 52 suggests that the prophecy was originally given by Themis, and that Aeschylus (P.D. 209-10) invented the story to give Prometheus some leverage over Zeus.
} 
later writers suggest that Thetis refused to marry Zeus as a favour to $\mathrm{Hera}^{54}$, she might actually have wanted to marry him, also as a favour to Hera. This interpretation also helps to illuminate why Thetis tried to refuse Peleus' hand.

In the Homeric Hymn to Apollo (321), Hera mentions Thetis in a conspicuous way. After speaking of Hephaestus, whom she threw from heaven down to the ocean because he was lame, she suddenly speaks of Thetis:

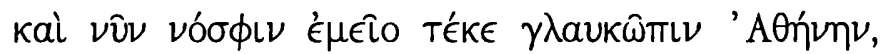

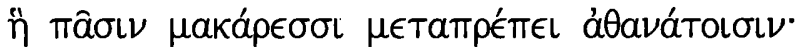

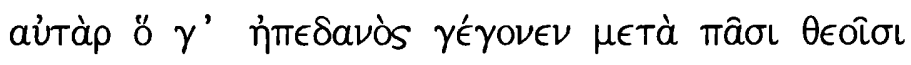

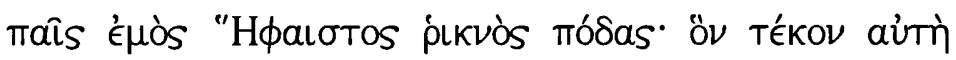

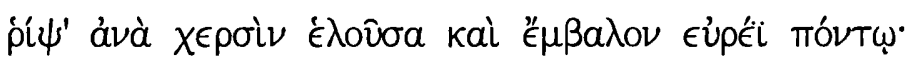

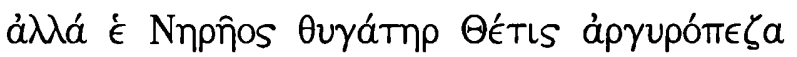

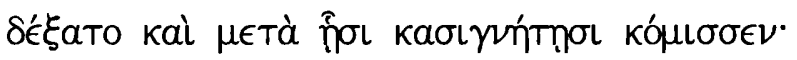

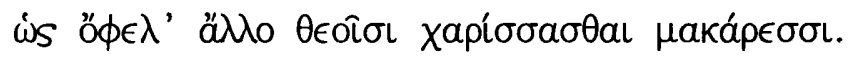

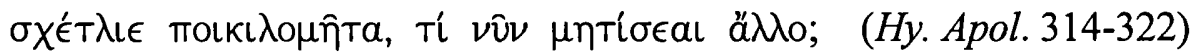

....and now apart from me gave birth to gray-eyed Athena, who excels among all the blessed immortals. But my son, Hephaestus, whom I myself bore has grown to be weak-legged and lame among the blessed gods. I took him with my own hands and cast him into the broad sea. But Thetis, the silver-footed daughter of Nereus, received him and with her sisters took him in her care. I wish she had done the blessed gods some other favour! O stubborn and wily one! What else will you now devise? (Tr. A. Athanassakis)

\footnotetext{
${ }^{54}$ Note that Apollodorus offers the different versions as alternatives without opting for a 'real reason'.
} 
The disjointedness of the narrative is not without its problems: some editors assume a lacuna between 317 and $318 .^{55}$ In addition, Hera leaves the meaning of a $a \lambda \lambda_{0}$ open, and does not specify what she would have preferred Thetis to do; immediately following this oblique comment, she changes the topic to Zeus and her fear of some new contrivance. It is clear that Thetis' act - saving Hephaestus in the ocean - was not what Hera wanted. In this sense, one interpretation of åd $\lambda$ o would be 'leaving Hephaestus to perish instead of saving him.. However this partial interpretation-does not explain why destroying Hephaestus would be a favour for the gods (321).

I propose that Hera's words imply that her intention was cosmic in scale. What was it that could have been helpful not only for Hera herself, but also for the other gods? Let us re-examine the context in detail: Zeus alone begat Athena, and she is most excellent by far among "all the blessed gods" (314-5), whereas Hephaestus was born lame among "all the gods" (316). The narrative concentrates on child-birth and its ramifications for the gods. Thus, when Hera wishes that Thetis had done

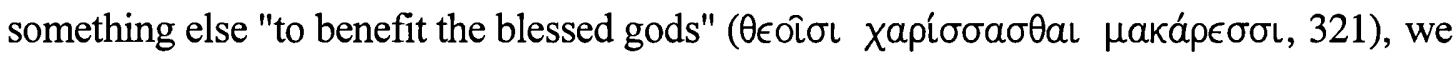
may read this to denote, again, the potentiality that underscores Thetis' characterisation as a child-bearer in the Iliad: her potential ability to give birth to a son who is mightier than his father. In sum, had Thetis married Zeus, and her son overthrown him, this is what would have been beneficial to the blessed gods who are themselves subject to Zeus.

\footnotetext{
${ }^{55}$ Cf. Chapter V, n. 26 below.
} 
Since Hera's own son, Hephaestus, is handicapped, she would wish for a powerful child from Thetis. If only Thetis could have fulfilled her potentiality, and given birth to a child by Zeus, Hera could have avenged herself on her adversary. On this reading, Hera's å $\lambda \lambda$ o would carry the implication, 'Instead of saving Hephaestus, if she had given birth to a child who was far mightier than Zeus'. ${ }^{56}$ Any precise

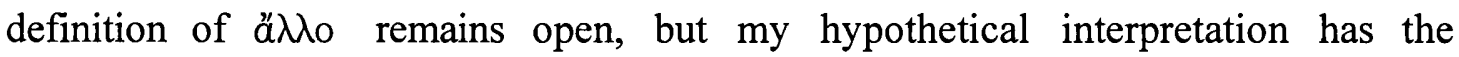
advantages of complementing both immediate and intertextual contexts. That is, we can certainly conjecture that an ancient audience, familiar with the stories surrounding Thetis, would have been reminded of other references to Thetis' essential potentiality by this pointed å $\lambda \lambda$ o.

Hera is always conscious of the other gods and regards her situation not as a personal problem between divine husband and wife, but as a problem for the whole divine world. ${ }^{57}$ Note, for instance, the clear antagonism in Iliad 15 between Zeus, on the one side, and Hera and the rest of the gods, on the other. After quarrelling with Zeus (15.14-46), Hera returns to Olympus to join the gathering of the gods

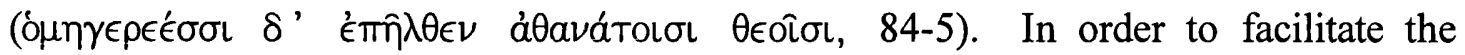
involvement of the other gods in the quarrel, she emphasises her own inclusion among them (92-148); this explains why she uses the plural pronoun 'we' (not the singular 'I') when speaking of the quarrel, although it was, in fact, between her and Zeus: "how foolish we are, thoughtless to storm against Zeus..." (104). The word vńmเos is also

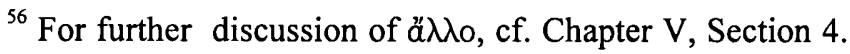


significant. She appears to regret having resisted Zeus, but actually she is irritated by their past failure, and is still seeking a way to conspire against him. As Janko rightly remarks, ${ }^{58}$ 'Hera overtly advises submission, but covertly stirs up revolt'. If Hera intervenes in the succession of the supreme god, the cosmic order will change - and inevitably all the gods will be involved. This is what Hera intends, and, for this purpose, we see, again, that Hera has a vested interest in the upbringing of Thetis.

To substantiate Hera's purpose, other remarks in the Homeric Hymn to Apollo are worth examining. Before the passage concerning Thetis, Hera speaks about Hephaestus in comparison with Athena at 314-322, as cited above. Hera is dissatisfied because her disabled Hephaestus cannot compare to Athena. She must have previously desired a powerful child: hence, on this occasion, she speaks about Thetis' rescue of Hephaestus. Let us note, too, that the contrast between Athena's ability and Hephaestus' disability corresponds with Zeus' capability and Hera's incapability. It is not surprising, therefore, that Hera is prompted to consider using the prophecy about Thetis as her revenge on Zeus.

It is also significant that Hera thinks of Zeus just after mentioning Thetis (322). The two epithets in this verse, $\sigma \chi \chi^{\prime} \epsilon \top \lambda_{\iota} \epsilon$ and $\pi \circ\llcorner\kappa \iota \lambda o \mu \hat{\eta} \tau \alpha$, are appropriate expressions in this context for Hera to describe Zeus. ${ }^{59}$ She is anxious that Zeus might contrive 'something else' (ä $\lambda \lambda \mathrm{o}, 322)$; in order to compete with Zeus, Hera

\footnotetext{
${ }^{57}$ Nilsson (1932) 221ff., followed by Griffin (1980) 186, suggests that the concept of a unified divine society is a creation of the epic, which is influenced by the religious ideas current in the second millennium B.C.

${ }^{58}$ Janko (1992) ad 15. 104-12.
} 
needs to contrive 'something else' (ä $\lambda$ o, 321), which might, as suggested above, be to procure a god (born from Thetis) who will be mightier than Zeus. There is a strong case for suggesting that Hera's hostility to Zeus underlies the passage describing her upbringing of Thetis (Iliad 24. 61). This is supported by the Homeric Hymn to Apollo and later sources, such as Apollonius Rhodius and Apollodorus. After Hera has given birth to her crippled child Hephaestus, and rejected him, any hope for revenge must reside in her plan for Thetis.

The marriage of Peleus and Thetis is twice mentioned by Achilles in the Iliad at 18. 79-93 and 24. 534-7. Let us consider the first passage: Achilles is bemoaning

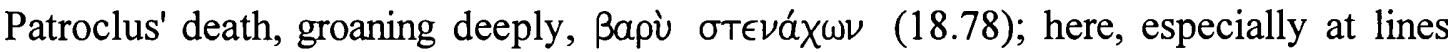
84-87, Achilles explictly says that it is a marriage with an unfortunate outcome:

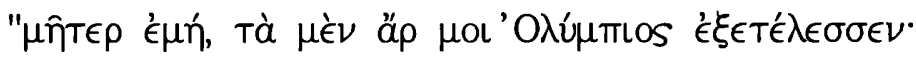

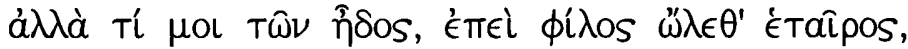

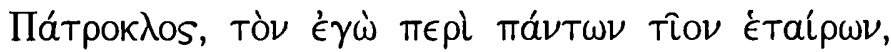

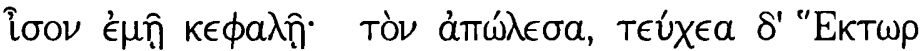

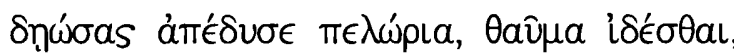

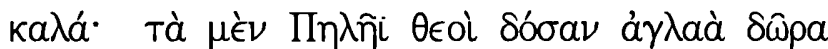

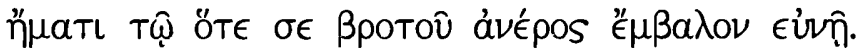

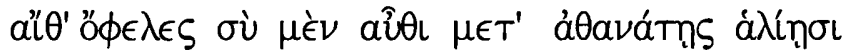

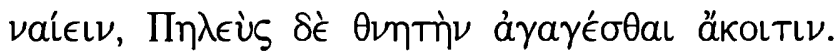

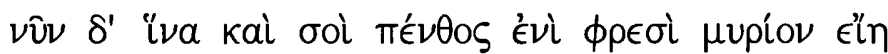

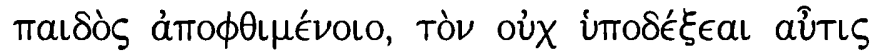

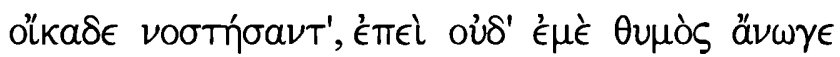

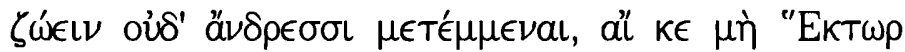

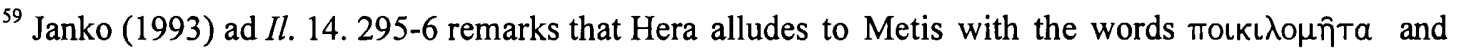

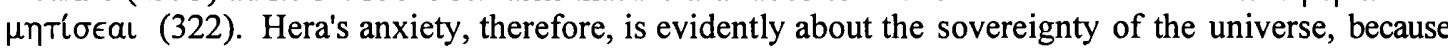




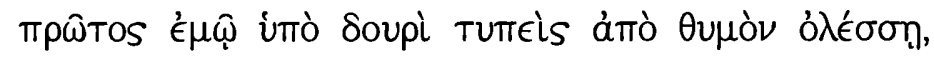

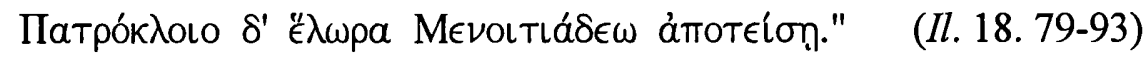

"Mother, yes, the Olympian has done all this for me. But what pleasure can I take in it, when my dear friend is killed, Patroklos, a man I honoured above all my companions, as much as my own life. I have lost him, and Hektor who killed him has stripped the huge armour from him, that lovely armour, wonderful to see, which the gods gave as a splendid gift to Peleus on the day when they brought you to a mortal man's bed. If only you had stayed in your home with the immortal goddesses of the sea, and Peleus had married a mortal wife! But as it is there must now be countless sorrow for your heart too, for the death of a son you will never welcome back to his home - since my heart has no wish for me to live or continue among men, unless first Hektor is struck down by my spear and loses his life, and pays me the price for taking Patroklos son of Menoitios. "

(Tr. M. Hammond)

Thetis had come out of the sea in order to ask Achilles why he was crying (18.65-77): he expresses profound grief at Patroclus' death (18.80-3), explaining its traumatic effect on him. However, his attention than shifts from the death of Patroclus to the marriage of his parents, with the divine armour functioning as the element which connects the two topics. At the news of Patroclus' death, Achilles immediately recognises his own identity and mortality, and thus his parents' marriage surfaces in his thought processes.

When Achilles says to Thetis that 'the gods brought ( of a mortal man' (85), it is implied that the choice was not hers. ${ }^{60}$ He bewails the fact that Thetis did not stay in her home with the immortal goddesses of the sea, leaving Peleus to marry a mortal wife (86-7). Despondent over the circumstances of his

\footnotetext{
swallowing Metis and begetting Athena were contrived by Zeus precisely for that purpose.

${ }^{60}$ Edwards (1991) ad loc. makes the point that $\ddot{E} \mu \beta a \lambda o \nu$ does not imply violence. However, the

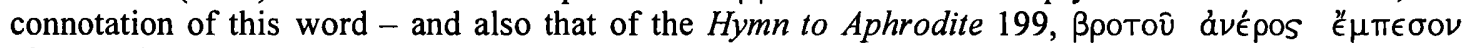
$\epsilon \cup \mathfrak{v}$, which Edwards himself cites - seems to be of an unwilling marriage.
} 
parents' marriage, his words can be read as a protest against the will of Zeus who had arranged it in order to deprive Thetis of her potentiality. Achilles' lament, therefore, can be read on two levels: it is not only for the death of Patroclus, but also for himself, since Patroclus' death recalls his parents' fateful marriage, and subsequently his own birth. ${ }^{61}$ His double lament is closely linked at last.

Although Achilles appears indifferent to his father in this passage, elsewhere he is very sympathetic to Peleus. Let us consider the second passage, from book 24 , where Achilles' attitude toward Peleus seems much milder. Significantly, the Iliad ends with the reconciliation of Achilles and Priam, to whom Achilles compares his own father. This scene is so familiar that a few specific comments will suffice in order to show the importance of Peleus. When Achilles first sees Priam, who has come to supplicate him with an enormous ransom, he is amazed. In this "most dramatic moment in the whole of the Iliad," ${ }^{12}$ a significant simile is deployed - that of a homicide who goes into exile and seeks refuge in the home of a rich man:

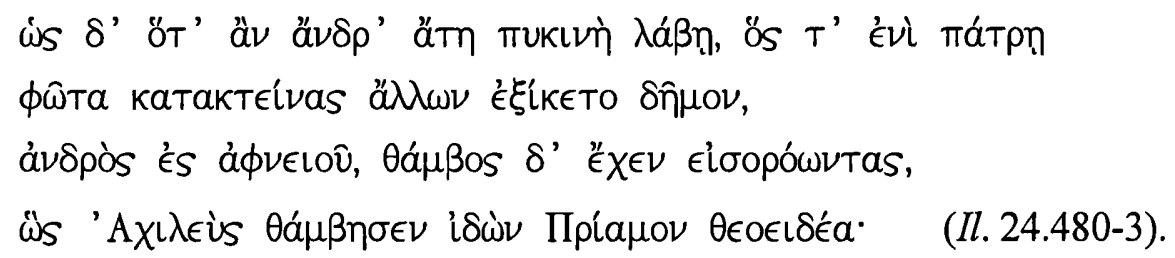

As when a man is held fast by blind folly - he kills a man in his own country, and then comes to another land, to a rich man's house, and amazement takes those who see his entry. So Achilles was amazed when he saw godlike Priam. (Tr. M. Hammond)

\footnotetext{
${ }^{61}$ I agree with the neoanalytic interpretation of Patroclus' death as paralleled by Achilles'; for example Whitman (1958) 199, Nagy (1979) 292-3, and Edwards (1991) 15.

${ }^{62}$ Richardson (1993) ad loc.
} 
This simile is variously interpreted as either expressing simple amazement at the unexpectedness of Priam's arrival, ${ }^{63}$ or representing the concept of pollution which attends bloodshed. ${ }^{64}$ These interpretations are valid, but Richardson is surely correct to point out that the use of this particular simile suggests that there is more at stake here than mere surprise or curiosity. ${ }^{65}$ Richardson does not specify what this might be, but I contend that it functions as a subtle reminder of Peleus, since it is he who frequently accepts suppliants in the Iliad. Further, I suggest that this effective encapsulation of Peleus' past behaviour foreshadows Achilles' acceptance of Priam's supplication. Priam's speech, which inspires the reconciliation, is an effective ringcomposition, beginning and ending with mention of Peleus: ${ }^{66}$

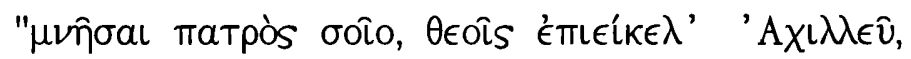

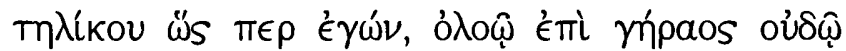

"Think of your father, godlike Achilles, an old man like I am, at the cruel edge of old age. (Tr. M. Hammond)

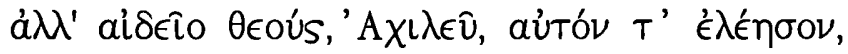

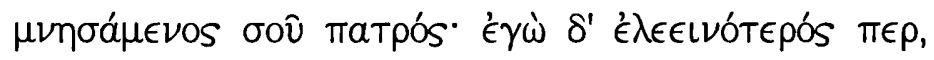
(Il. 24. 503-6)

\footnotetext{
${ }^{63}$ Macleod (1982) ad loc.

${ }^{64}$ Gould (1973) 96, n.111.

${ }^{65}$ Richardson (1993) ad loc. also notes "the reversal of roles": in the narrative it is the supplicated man who is the killer, and the suppliant who is the rich man.

${ }^{66}$ Richardson (1993) ad loc.
} 
Respect the gods, then, Achilles, and have pity on me, remembering your own father. But I am yet more pitiable than he. (Tr. M. Hammond)

This appeal emphasises Peleus' vital importance to Priam's supplication because it enables him to establish an empathetic bond with Achilles. ${ }^{67}$ Let us consider why Peleus plays such a decisive role in the grand finale of the epic. ${ }^{68}$ As Edwards rightly notes, ${ }^{69}$ on the level of narrative structure, there is a long sequence of father-and-son relationships: Zeus' loss of his son Sarpedon, and Patroclus' killing of Priam's sons, Lykaon and Polydoros. In addition, Peleus is characterised as a respectable host, and this, too, finds an echo in the simile of the rich man (24. 480-2). Further to these observations, I propose that, once again, a resonance of 'generational myth' is operating, and here it prefigures Priam's successful supplication.

As I have discussed, because of Thetis' potentiality, Achilles might have been mightier than his father. Achilles, however, could not fully develop his ability to intervene in the succession-myth, ${ }^{70}$ and although elsewhere he displays affection for his father, his frustration with his own mortal inadequacy causes him to lament his parents' marriage and his own genealogy. We remember that, at the very beginning of the poem, when Achilles asks Thetis to supplicate Zeus, his rationale was that Zeus

\footnotetext{
${ }^{67}$ Lynn-George (1988) 242 notes the language in Priam's statement, pointing out that 'Priam's discourse is constructed as the choice of a word; from among the possibilities recommended by the god, Priam selects one; this word, "father".'

${ }^{88}$ Kim (2000) 23-63, esp. p. 33, tries to answer this question by establishing Achilles' pity for Priam as a $\phi i$ i os. I agree, but my concern is rather what induces Achilles' pity for Priam.

${ }^{69}$ Edwards (1991) 10.

${ }^{70}$ Rutherford (1982) 146 also points out Achilles' inability as the archetypal tragic figure: for all his power and greatness, Achilles is unable to dictate or influence the course of future events.
} 
could have been his father, ${ }^{71}$ and that this was also germane to Thetis' claim. Upon Patroclus' death, he expressed his antagonism to the marriage of his parents, protesting against the will of Zeus; but now, faced with the aged Priam, Achilles realises that this generational strife should be peacefully resolved. In this scene, Achilles is reconciled not only with the father of his most hated enemy, but also with his own father, his own genealogy, and his own mortality. His recognition of his own mortal destiny articulates for us a new appreciation of this age-old generational strife: in this case, the younger and mightier son will not overcome, but venerate, his father.

Achilles' attitude towards Peleus provides many depictions of an ideal relationship between father and son: Achilles asks Patroclus if there is any news from Phthia to indicate whether Peleus is alive (16.15); Achilles laments his father, who cannot welcome his son home (18.331), and who may no longer be alive or may be suffering the pain of old age (19.334-7). Peleus, too, is affectionate toward his son. His thoughtful farewell messages for Achilles on his departure to Troy are reported by Odysseus (9.252-8), Phoenix (9.438-43), and Achilles himself (23.144-9). Achilles even wishes to live 'in enjoyment of the wealth that old Peleus has won' (9.400). As well as this ideal relationship, the personality of Peleus is carefully depicted as an exemplar of hospitality in the Iliad. He welcomes as many as four people to his palace: Nestor (11.772-9), Phoenix (9.480-4), Epeigeus (16.571-4), and Patroclus $(23.87-90)$. It is particularly significant that the last three all come to his house as

\footnotetext{
${ }^{71}$ O'Brien (1993) 79 explains that Achilles is reconciled with Priam in response to Zeus' new ethic of pity, retreating from Hera's hatred. While this is plausible, I would stress, in addition, Achilles' selfreintegration within his own genealogy.
} 
suppliants, expelled from their own lands because of a homicide or some domestic trouble. There seems to be a very careful attempt to introduce Peleus as a respectful host towards the suppliants who seek refuge in his house. ${ }^{72}$

Note especially the story of Phoenix: Peleus gladly welcomes him, and loves him like a son: ${ }^{73}$

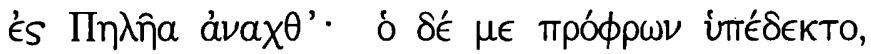

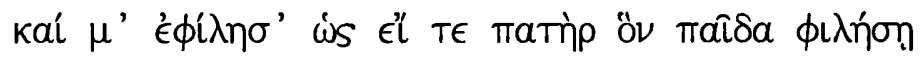

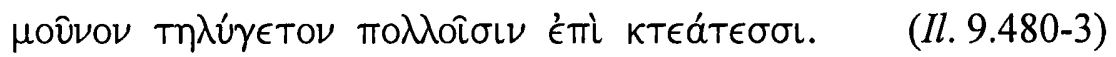

...to king Peleus' house. He welcomed me gladly, and loved me as a father loves his son who is an only child, late-born, the heir to many possessions.

\section{(Tr. M. Hammond)}

Phoenix is cherished and protected by this substitute-father, Peleus. This characterisation of Peleus as a good father foreshadows the reconciliation of Achilles and Priam. Looking at Priam, Achilles thinks of Peleus: in this sense, Priam is a substitute for Achilles' father. It seems that the stories of Peleus' welcome to

\footnotetext{
${ }^{72}$ Peleus held Thetis by force to win her: she tried to escape him by changing her shape into fire, water, wind, a tree, a bird, a lion, snake and cuttlefish (cf. Pindar N. 4.62ff; Pausanias 5.18.5; Apollod. 3.13.5). This myth suggests that Peleus raped Thetis: but this story also demonstrates the physical excellence required to win a divine bride. It is significant that the Iliad 's portrayal of the elderly Peleus emphasises his decency as a mediator in domestic problems and glosses over the fact that he married Thetis against her will.

is, however, that Peleus is deliberately portrayed as kind and respectable person.

${ }^{73}$ Phoenix became ómá $\omega \nu$ of Peleus. For the relationship of ơmá $\omega \nu$, see Hainsworth (1993) ad loc.
} 
suppliants are narrated in preparation for the final scene of the epic - the presentation of a new father-son relationship. ${ }^{74}$

While repeated rejection of supplication or prayer is conspicuous throughout the Iliad, $^{75}$ it is significant that the poem is framed by two acceptances of supplication: that of Thetis to Zeus, and Priam to Achilles. Slatkin observes that 'cosmic equilibrium is bought at the cost of human mortality'; 'the alternative would mean perpetual evolution, perpetual violent succession, perpetual disorder...'; she concludes that 'the wrath of Thetis...becomes absorbed in the actual wrath of her son. ${ }^{176}$ I would support this interpretation, but I further submit that the characterisation of Peleus is the key to resolving various problems: on the cosmic level, his marriage with Thetis secures Zeus' sovereignty; and on the human level, Achilles' anger evaporates at the recollection of him. Consequently, the suffering of Achilles and the sympathy which he feels for Priam can be more fully understood by recognising the significance of Peleus in the succession myth. ${ }^{77}$

The myth of generational strife resonates throughout the Iliad, and it has a profound effect on the poem. There was perhaps an early, lost myth in which Zeus had to fight not only giants and monsters but also his own son, ${ }^{78}$ possibly born of

\footnotetext{
${ }^{74}$ These images of Peleus imply a parallel with Thetis, who rescued Dionysus (6.132-7) and Hephaestus (18.395-405).

75 Alden (2000) 290 emphasises the rejection of $\lambda$ เTal, giving references such as Chryses to Agamemnon in book 1; the embassy in book 9; Priam and Hecuba to Hector in book 22; and Hector and Achilles in book 22.

${ }_{77}^{76}$ Slatkin (1991) 103.

${ }^{77}$ I agree with Rutherford (1982) 160 who comments that it is part of human nature to seek to comprehend the course of events even when they are beyond human understanding. The characterisation of Peleus here seems to be a good example of "the course of events".

${ }^{78}$ Caldwell (1989) 179.
} 
Thetis. From the very beginning of the Iliad, the motif of "the son mightier than his father" is clearly recognisable through Achilles' own words, and the poem ends not with the defeat of Hector or the death of Achilles, but, in the most ingenious way, with a peaceful reconciliation between Achilles and Priam, which achieves a completely new understanding of this generational strife. The extraordinarily wrought narrative of the wrath of Achilles progresses from initial desire for heroic $\tau \iota \mu \eta ́$ against Agamemnon and Hector, to a realisation of himself and his own mortality. Thus the $\Delta$ ıòs $\beta$ oùń will be fulfilled: Zeus has now successfully escaped the danger of Thetis' potentiality. ${ }^{79}$ As Lynn-George notes, ${ }^{80}$ the imperfect verb

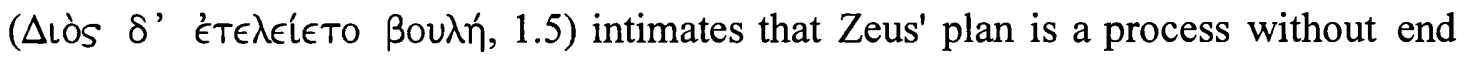
and, at the same time, without beginning; certainly, we are not informed when the plan was conceived and when it was fulfilled. Among the various possible interpretations of the plan, the reduction of the population of the earth is but one ${ }^{81}$, and in this chapter I have suggested that, in addition, the theme of 'overcoming the threat of a mightier son' must surely be recognised as a deep and subtle undercurrent through the Iliad.

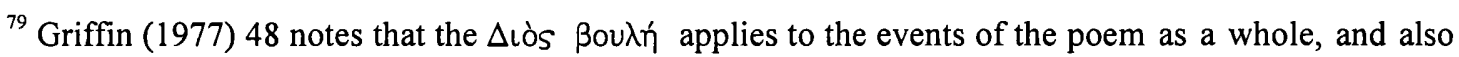
to the plan which Zeus devises with Thetis. I would emphasise the latter..

${ }^{80}$ Lynn-George (1988) 38-9.

${ }^{81}$ Cypria fr. 1; Schol. Il. 1.5.
} 


\section{Chapter II : The Golden Chain of Hera}

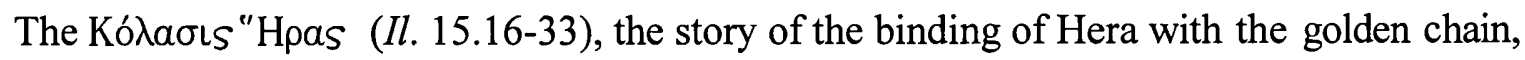
is unique in the Iliad: the highest goddess of Olympus is humiliated, bound up and hung by her husband. Its uniqueness might explain why Zenodotus athetised the passage (15.18-31). However, Hera's punishment has a deeper significance in the story than might first appear, and in this chapter, I view this passage from the perspective of cosmic strife. ${ }^{1}$ The story appears to derive from an earlier tradition of the battle of the gods. Behind Hera's punishment one can detect the vestiges of her challenge to Zeus. Throughout the Iliad there are suggestions of threats of rebellion in which Hera acts as a ringleader, and among these accounts, the story of her binding deserves special attention.

Hera's role in the Iliad is rather comical. Even when she becomes angry, her behaviour provokes laughter from the audience: for example, when she is jealous of Zeus and Thetis (1.531-67), or when she is furious at being scolded by Zeus (8.432-68). These scenes are amusing because the gods do not behave as one would expect them to: instead, they are involved in seemingly ordinary domestic troubles. ${ }^{2}$ It is understandable, in this respect, that Heracles should state of the gods in Euripides' Heracles (1341-4) that 'I do not think, have never believed, and will never be convinced that the gods have illicit love affairs or bind each other with chains, or that one can be master of another' (tr. David

\footnotetext{
${ }^{1}$ I agree with Janko (1992) ad 15.18-31, who comments that the story has latent cosmic implications.
} 
Kovacs). By depicting Hera's story in terms of a punishment by a husband within a family, and by telling it as a story of the remote past, the strategy of the poet of the Iliad seems to be to make the story laughable. However, as I will argue, behind the comic features of this story lies a dangerous tension between the gods, and one can trace a grim subtext of punishment as a consequence of divine conflict.

Hera, after all, is a significant and complex figure in the Iliad, as a recurrent obstacle to Zeus' plans, as O'Brien emphasises, ${ }^{3}$ even if she is ultimately unable to thwart him. She has great power among the Olympians and has many supporters, both overt and covert. Starting with the connotations of $\delta \epsilon \sigma \mu o ́ s$, I discuss the rebellion of Hera, her influence upon the other gods (especially Poseidon), and the role of Heracles in the rebellion, all of which are implied and hinted at in the lliad.

\section{The $\delta \epsilon \sigma \mu \delta s$ of the gods in the Iliad}

When Zeus awakes from Hera's side and finds the Trojans fleeing in confusion (Il. 15.47), he furiously threatens Hera, reminding her of a previous punishment which he inflicted, namely hanging her in the sky with anvils on her feet (15.18-9). This scene is often discussed in tandem with a similar story, that of the suspension of the Olympians in their tug-of-war with Zeus (8.19-27). ${ }^{4}$ Zeus, hanging a gold cord from heaven, boasts

\footnotetext{
${ }^{2}$ Griffin (1980) 146 points out that 'the gods of the Iliad are in fact the chief source of comedy in the poem; ...the gods of the Iliad belong to the conventional world of epic and were understood as such by the audience.'

${ }^{3}$ O'Brien (1993) 77.

${ }^{4}$ For example, Whitman (1971) 39.
} 
that all the gods and goddesses could not pull him down. Moreover, he proclaims that he will fasten the cord round a peak of Olympus, so that everything and everyone - earth, sea, and the gods - would be suspended in mid-air. Certainly, these stories have similarities: both contain the motif of hanging in the air; the material used for the hanging is gold; and Zeus himself tells both stories for the purpose of asserting his overwhelming power. There is, however, a significant difference, often neglected, between the two

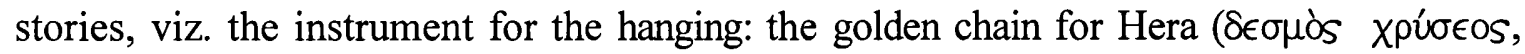

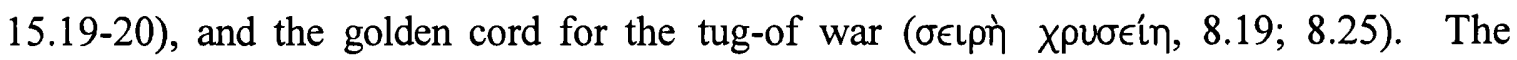
difference is significant because these two words convey the characteristic tone of these two stories. On the one hand, the cord signifies a mere sport, as the light-hearted tone of

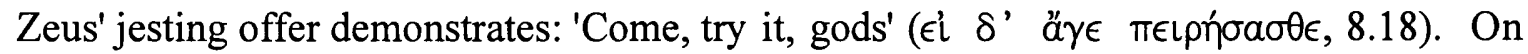
the other hand, the chain signifies severe punishment. I suggest that the poet of the Iliad makes a precise distinction between $\sigma \epsilon \iota p \eta ́$ and $\delta \epsilon \sigma \mu o ́ s:$ the grievous connotation of $\delta \epsilon \sigma \mu o ́ s$ effectively emphasises the great disgrace involved in this harshest of punishments suffered by Hera. ${ }^{5}$

The word $\delta \epsilon \sigma \mu o ́ s$ is used infrequently and with care in the Iliad. It occurs nine times, always with reference either to the Trojans or the gods, but never to the Greeks. When the word is applied to the Trojans (four times), it is a general term for 'fastening' with no implication of punishment: it signifies 'halter' in the two identical similes which denote Paris and Hector $(6.507=15.264)$; it also refers to the binding of Dolon $(10.443)$

\footnotetext{
${ }^{5}$ Eliade (1961) 123 offers an interesting suggestion: it is only among Indo-Europeans that the 'binding' complex is originally integrated into the structure of 'terrible' sovereignty, both divine and human. In the
} 
and the hair-band of Andromache (22.468). Although the use of the word in these accounts has interesting features, ${ }^{6}$ our concern at the moment is for its use in reference to the gods.

In the divine context, a $\delta \epsilon \sigma \mu o ́ s$ carries a more or less dangerous connotation, since binding is the supreme penalty for the gods who, by definition, can never die. The motif of binding on Olympus evokes the succession myth. ${ }^{7}$ For example, the binding of the Cyclopes (Theog. 501-2) and that of the Hekatoncheires (Theog. 617-8) are mentioned in the context of the struggle for sovereignty between the old gods and the new power under Zeus' control. $^{8}$ In the Theogony, the theme of binding is thus an integral part of the myth about sovereignty. In the Iliad, however, the connotations of $\delta \epsilon \sigma \mu$ ós have a wider range. There are five examples of divine $\delta \epsilon \sigma \mu o ́ s:$ Zeus bound (1.401); the fastenings (rivets) of Hephaestus (in the plural, 18.379); Ares bound $(5.391,386)$; and the golden chain of Hera (15.19). I will discuss the last four examples, leaving Zeus' binding to another chapter.

Hephaestus was forging the fastenings ( $\delta \in \sigma \mu o u ́ s, 18.379)$ for his twenty tripods, when Thetis came to his house, asking him to make Achilles' shield (18.368-379). The theme and diction of this account are telling, although it is the enjoyable side of this story which is usually emphasised; for example, Edwards comments that 'this scene comes as a

Enuma Elish 1.60-74, Ea binds the primordial monsters Mummû and Apsû with a magic incantation, and then kills them.

${ }^{6}$ All of these passages use the word $\delta \epsilon \sigma \mu$ ós with special significance, especially in the case of Andromache's hair-band: $\delta \epsilon \sigma \mu \delta ́ s$ signifies her peaceful domestic world, since it is used when women do

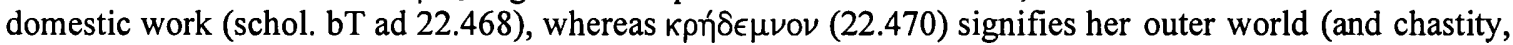
see Nagler [1967] 299), since it is used when women go outdoors. Accordingly when Andromache throws off both her $\delta \epsilon \sigma \mu o ́ s$ and $\kappa \rho \eta ́ \delta \epsilon \mu \nu \nu \nu$ at Hector's death, it signifies the destruction of her whole life, both internal and external, domestic and social.

${ }^{7}$ Slatkin (1991) 67 notes that binding is a primary way of asserting divine sovereignty over a potential or actual challenger. 
relief after the sorrows [of the death of Patroclus]'; ${ }^{\prime}$ Austin suggests that the five speeches between Thetis, Charis and Hephaestus repeat the theme of hospitality and past indebtedness, while slowly advancing toward the present need; ${ }^{10}$ a scholiast notes the sense of joy surrounding the half-finished work (schol. bT ad 18.379). I agree that part of the attraction of the story lies in its enjoyable aspect. However, I think that we can read further, behind the narrative, as is largely suggested by the weighty word $\delta \in \sigma \mu$ oús. Let us examine the account of the tripods:

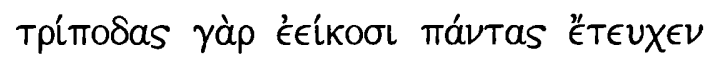

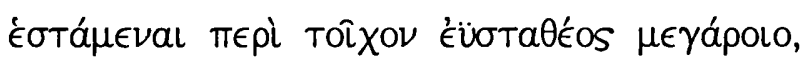

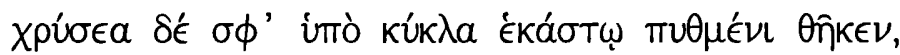

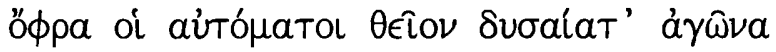

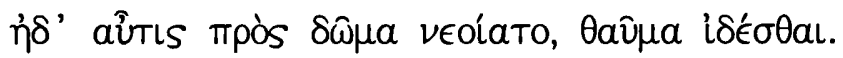

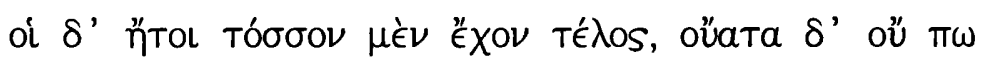

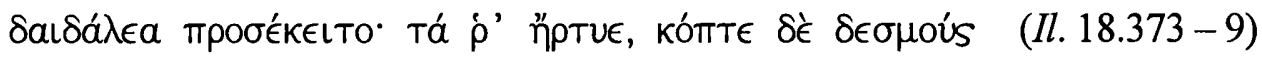

He was making a set of twenty tripods to stand along the wall of his strong-built house, and had fitted them with golden wheels under each leg, so he could have them moving of their own accord, running by themselves to where the gods were gathered and then returning again to his house - a miraculous sight. They were so far finished, but the worked handles had not yet been added: he was fitting these, and forging the rivets.

(Tr. M. Hammond)

\footnotetext{
${ }^{8}$ Détienne and Vernant (1978) 72-3 note that no mention of binding is offered as long as the story remains on the cosmological level of the relationship between Gaia and Uranus.

${ }^{9}$ Edwards (1991) 189.

${ }^{10}$ Austin (1966) 309.
} 
What is remarkable about this story is that Hephaestus has not finished the tripods, but is still at work forging the fastenings $(\delta \in \sigma \mu o \mathrm{l})$. It is a topos that when a person arrives, he interrupts some on-going activity: for example Achilles is singing when Phoenix, Odysseus and Ajax visit him (Il. 9. 189); Calypso is singing and working before the loom when Hermes visits her $(O d .5 .61-2)$. However, in the case of Thetis' visiting Hepahestus, let us note that the work which is interrupted is specifically mentioned as forging $\delta \epsilon \sigma \mu o$. $^{11}$ The significance of the unfinished work is that it reveals the $\delta \epsilon \sigma \mu o$, before they are fitted to the tripod. The passage thus characterises Hephaestus as the god of forging $\delta \epsilon \sigma \mu o^{12}{ }^{12}$ Abundant fastenings ( $\delta \epsilon \sigma \mu o$ ) are now prepared for the tripods, and this functions to emphasise Hephaestus' role in forging $\delta \epsilon \sigma \mu o$ for the gods.

Further, let us examine the two speeches of Zeus and Hera (354-67) preceding the tripod-making, which emphasise the danger of the situation :

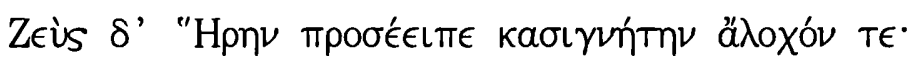

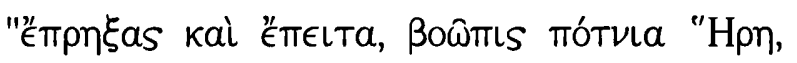

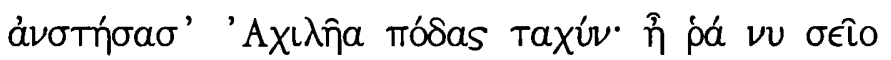

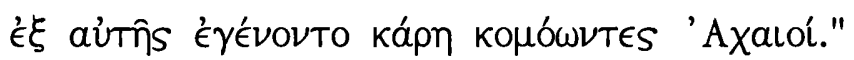

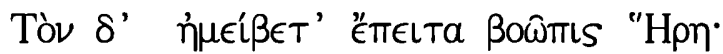

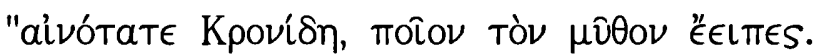

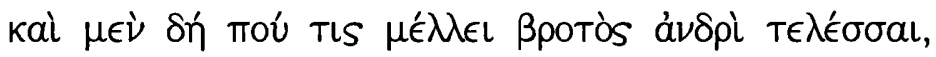

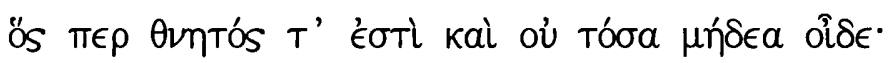

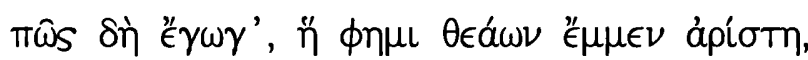

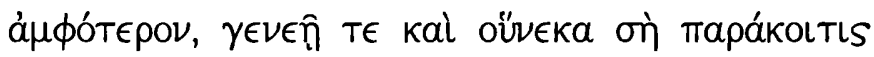

\footnotetext{
"Hephaestus' laying down his tools in the middle of his task may also signify the enormity of the debt he owes to Thetis, who rescued him.

${ }_{12}$ The scholiast is quite right to note the significance of the unfinished work, although the aspect emphasised is different from mine.
} 


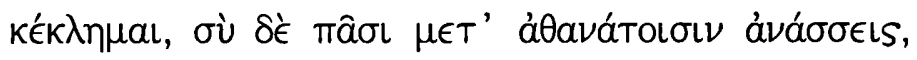

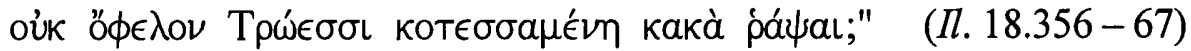

And Zeus spoke to Hera, his sister and wife: 'So you have achieved it in the end, ox-eyed Hera - you have stirred swift-footed Achilleus into action. It must be then that you are mother to all the long-haired Achaians, and they your children. ' Then the ox-eyed queen Hera answered him: 'Dread son of Kronos, what is this you are saying? Even men will achieve their purposes for other men, though they are mortal and without the knowledge that we have. How then, when my claim is to be the greatest of goddesses, for double reason, both by birth and because I am called your wife, and you are lord over all the immortals - how could I not weave trouble for the Trojans, when they have angered me?' (Tr. M. Hammond)

This short quarrel strikingly breaks off the lament for Patroclus and the work of washing, anointing and clothing his corpse (343-55). The sudden change from a detailed description of laying out a dead human being to a divine conversation is dramatic and surprising, and Hera's dignified proclamation that 'I claim to be the greatest of the goddesses' (364) intensifies the dangerous tension between the two gods. The antagonism in this scene, coupled with the immediate switch of setting to Hephaestus' forge where he is working on chains, provides a subtextual echo of the gods' quarrel - and Zeus' threat to Hera of the golden chains - in book 15 . We see that the reference to Hephaestus' forging of chains is therefore particularly apt.

In the second song of Demodocus (Od. 8.266-320), Hephaestus' famous trap for catching Aphrodite and Ares is also called $\delta \epsilon \sigma \mu o \mathfrak{l}$

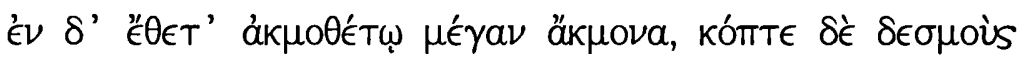

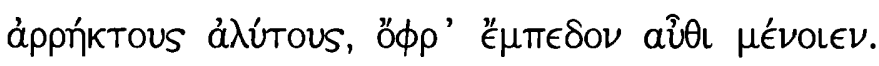

He laid the great anvil on its base and set himself to forge chains that could not be broken or torn asunder, being fashioned to bind the lovers fast. (Tr. W. Shewring) 


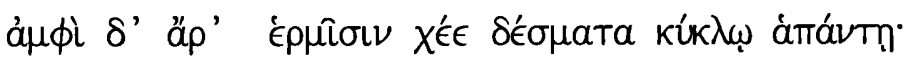

(Od. 8.278)

All round the bed-posts he dropped the chains (Tr. W. Shewring)

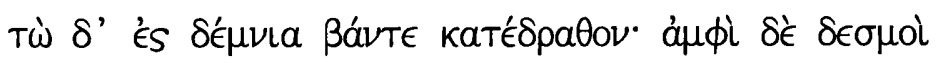

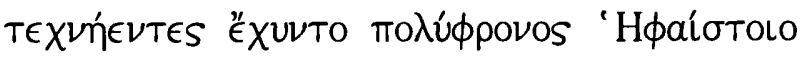

(Od. 8.296-7)

So they went to the bed and there lay down, but the cunning chains of crafty Hephaestus enveloped them.

(Tr. W. Shewring)

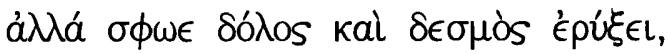

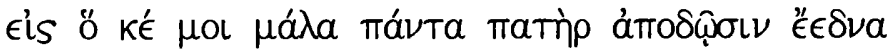

(Od. 8.317-8)

...but my cunning chains shall hold them both fast till her father Zeus has given me back all the betrothal gifts (Tr. W. Shewring)

His cunning contrivance is characterised by his bindings (or chains). We see, therefore, that Hephaestus is the god who forges impressive chains in both the Iliad and the Odyssey.

The binding of Ares (5.386 and 5.391) is one of three stories exemplifying gods who are damaged by mortals: Ares by Otos and Ephialtes (5.385-91), Hera by Heracles (5.392-4), and Hades (Aides) by Heracles (5.395-402). Together with the main narrative of Aphrodite wounded by Diomedes $(5.330-40),{ }^{13}$ Book 5 contains four similar types of

\footnotetext{
${ }^{13}$ West (2001a) 191-2 suspects 5. 338 for the following reasons: (a) Aphrodite's wound is in her hand, which would not be covered by her peplos; (b) 'through her robe' in 338 looks like an afterthought, coming as it does after mention of the wounding of her hand and the piercing of her skin; (c) the line interrupts the description of the flesh-wound; (d) neglect of digamma of the pronoun of. I hold reasons (a) to (c) as

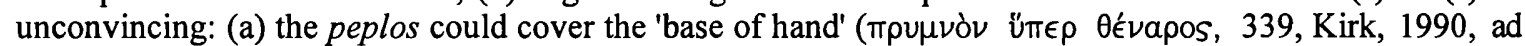
loc.), since it is nearer to the arm than to the fingers; (b) the description of the peplos (or a brief digression
} 
stories, but the story of Ares, in particular, exhibits distinctively different features. ${ }^{14}$ In the other three stories, the gods are wounded by a spear (Aphrodite) or an arrow (Hera

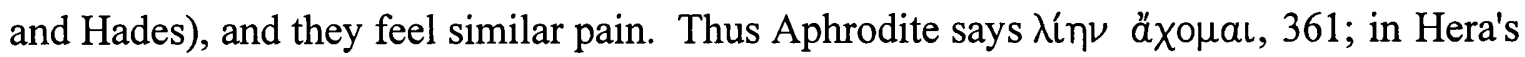

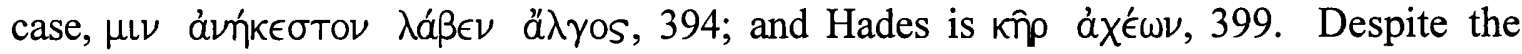
narration of their pains, they receive only grazes and soon recover. Bound by chains, however, Ares' suffering is quite different from theirs: his affliction is far more serious than 'pain'.

The battle between Ares and the twin Aloadai, Otos and Ephialtes, is presented at Odyssey 11.305-20. Although this story was athetised by Aristarchus, modern critics are disposed to accept it as genuine. ${ }^{15}$ It is significant that the scene bears some relation to the chaining of Hera. Otos and Ephialtes try to pile Pelion and Ossa on Olympus, threatening to attack the gods in the sky, but are killed by Apollo before they accomplish their endeavour. The twins are of monstrous size: about four metres across the shoulders

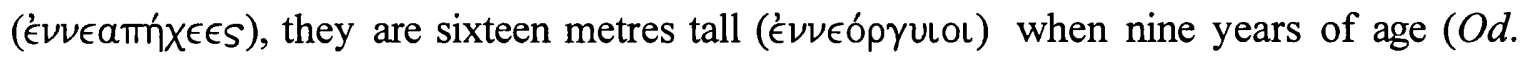
11.311-2). They might well be called 'Giants', though the poet of the Odyssey does not specify this. Like Typhon, to whom Earth gave birth (Theog. 821), the twins were

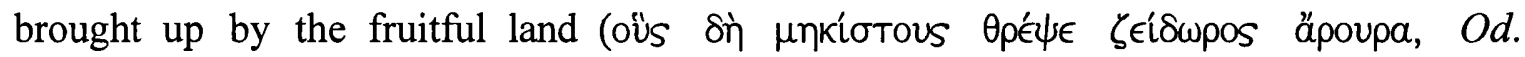

on peplos) is unlikely to be an 'afterthought'; (c) the effect of the digression is to intensify the significance of the event, although it seems to interrupt the account; cf. Austin (1966) 306.

${ }^{14}$ Willcock (1978) ad loc. suggests that this story is a Homeric invention; but I agree with Kirk (1990) ad loc. that it is unlikely. Kirk comments that this is too bizarre to be a plausible Homeric invention. I do not believe that whether or not a story is bizarre is a criterion. There are other stories of this sort: for example, Laomedon threatens to bind Poseidon and Apollo's feet and hands, and even to lop off their ears (Il. 21. 453-5).

${ }^{\text {is }}$ For example, van der Valk (1949) 189 argues that Aristarchus' athetesis is incorrect because of his 'prosaic mentality'; Hayman (1873) ad loc. suggests that the legend originated from a pre-Hellenic naturemyth; see also Heubeck and Hoekstra (1989) ad loc. 
11.309). Although it is sometimes suggested that Otos and Ephialtes are equivalent to Typhon and the Titans, ${ }^{16}$ they are similar only in their size and chthonic nature. In contrast with Typhon, a dreadful dragon with a dark, flickering tongue (Theog. 825-6), they are characterised as the most beautiful by far after Orion (Od. 11.310). These features fit well with many vase-paintings of archaic and classical date, which depict the Gigantes as fully human. ${ }^{17}$

The twins attempt to make a stairway to heaven, and in so doing they threaten revolution against the gods:

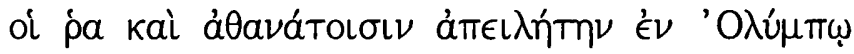

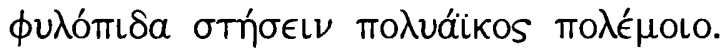

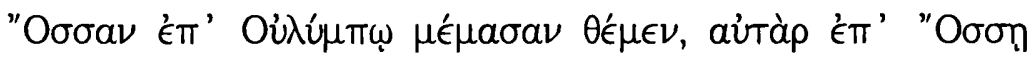

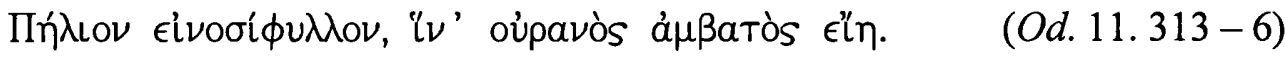

They threatened the deathless ones themselves - to embroil Olympus in all the fury and din of war. (Tr. W. Shewring)

They desired to pile Mount Ossa on Olympus, and wooded Pelion on Ossa, in order to make a stairway up to heaven. (My translation)

Their purpose in ascending to heaven is, of course, to occupy it, taking the place of the Olympian gods. Thus their threats (314) portend furious war against Zeus' sovereignty. It is tempting to guess that Otos and Ephialtes' unsuccessful assault would have featured

\footnotetext{
${ }^{16}$ Kirk (1990) ad Il. 5.385-7.

${ }^{17}$ However, Ap. $B .1 .6 .1-2$ narrates that the Gigantes are large and powerful with long hair and beards and scaly snakes for lower limbs. Gantz (1993) 477 notes that Hellenistic and later writers commonly confuse Titans and Gigantes. West (1966) ad Theog. 50 comments that, in Homer, the Gigantes occupy an intermediate position between men and gods, like the Laestrygonians $(O d .10 .120)$.
} 
as one of the scenes in the war of the Gigantes. This war receives only one mention in the

Odyssey, at 7.59:

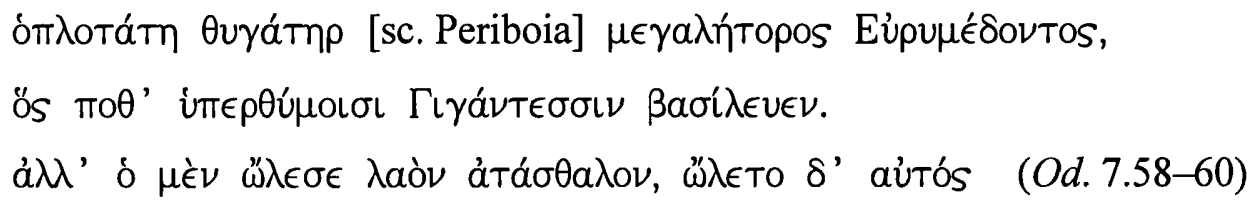

...the youngest daughter of bold Eurymedon, who once was king of the overbearing Giants, but then brought doom on his reckless people and on himself. (Tr. W. Shewring)

Eurymedon, king of the Gigantes, is defeated and killed in the war. There are several reasons for arguing for a combination of these two accounts, namely the threat to the gods from the Gigantic twins Otos and Ephialtes (Od. 11.305-20) and the defeat of the Gigantes led by king Eurymedon $(O d .7 .58-60) .{ }^{18}$ Although some sources treat these

\footnotetext{
${ }^{18}$ Although it is impossible to get rid of the speculative factors, the following are the possible reasons for assuming that these passages refer to a single event. First, both are characterised as transgressors of the moral, ritual and spiritual limits of their station. The race of Gigantes is called á $T a ́ \sigma \theta a \lambda o \nu$ in Book 7, and this is precisely how Otos and Ephialtes behave in Book 11: although they are mortal, they bind a god and attempt to ascend to heaven. Secondly, both accounts refer to the lineage of Poseidon: Otos and Ephialtes are sons of Poseidon (11.306-8), while Eurymedon is Poseidon's father-in-law (his daughter Periboia married Poseidon, 7.56-8). Thirdly, Apollo kills members of both groups: Otos and Ephialtes were killed by him (11.318-20), and Rhexenor, fourth generation after Eurymedon, was killed by Apollo (7. 63-4). Of course, as Apollo is involved in many human deaths, particularly untimely ones, this could also be a conventional expression for such a death. When we link these two stories (7. 58-60 and 11. 305-20) with the story of the binding of Ares (Il. 5. 385-91), a picture of the Gigantomachia could emerge. Eurymedon was the leader of the Gigantes; Otos and Ephialtes bound Ares; Otos and Ephialtes almost succeeded in ascending to heaven, but were too young to do so and were killed by Apollo; Eurymedon and his people were finally defeated by the gods.
} 
two events separately, ${ }^{19}$ if we could suppose that they are in some sense related to each other, the verses introductory to the story of the binding of Ares are worth looking at:

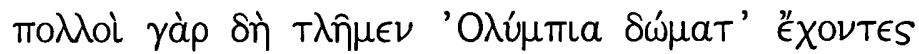

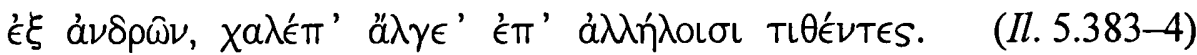

Many of us who have our homes on Olympus have suffered at men's hands, in the cruel pain that we bring on each other. (Tr. M. Hammond)

Dione makes this remark to Aphrodite in order to illustrate the general point that gods get into difficulties by involving themselves in mortal affairs. But the phrase '́m' à $\lambda \lambda \hat{n} \lambda$ oเ (384) may indicate that the war in which Ares was involved was not simply between Gigantes and gods; rather, the gods themselves fought against each other as well. ${ }^{20}$ As a Scholion (bT) elucidates, the gods injured each other and suffered cruel pain. ${ }^{21}$ The passage above implies for sure that when Ares was bound by Otos and Epialtes, he was involved in some quarrel that divided gods as well as men. This may or may not be the Gigantomachy, but at least we could say that it is this dangerous tension between the gods which, I suggest, is the key for understanding the myth of the golden chain of Hera.

\section{The golden chain of Hera}

\footnotetext{
${ }^{19}$ For example, in Pseudo-Nonnos (Or. 4), Ares' battle with them could be read as a separate expedition; in Stephanos (Ethnica 168) the battle is located in Crete; and Apollodorus 1. 55 locates their death on Naxos.

${ }^{20}$ Isocrates 10. 52 and Diodorus 4. 15. 1 regard all the Olympian gods as united on Zeus' side in the Gigantomachy. However, if we accept that the story of Ares' binding is an event from the Gigantomachy, then we might suggest that the gods fight with each other (as is narrated in general terms at $l l .5$. 383-4); the later writers might have ignored this passage of the Iliad.
} 
When Zeus awakens (15.4), he reasserts his invincible power. Hera's punishment is

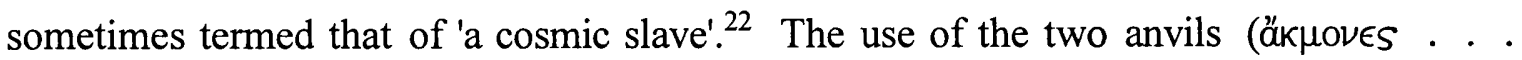
$\delta \dot{v} \omega, 15.19)$, tied to Hera's feet, surely in order to increase her pain, has intriguing implications: why is an anvil specified in this punishment? The anvil is an instrument for forging, from which we conclude that it must have belonged to Hephaestus. ${ }^{23}$ Moreover, when an anvil is mentioned, it is usually in conjunction with a chain, the two

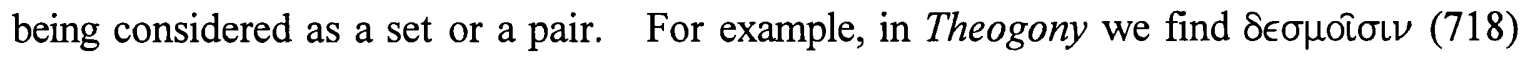
with äk $\mu \omega \nu$ (722); in the house of Hephaestus in the Iliad we read $\delta \epsilon \sigma \mu o u ́ s ~(18.379)$ with

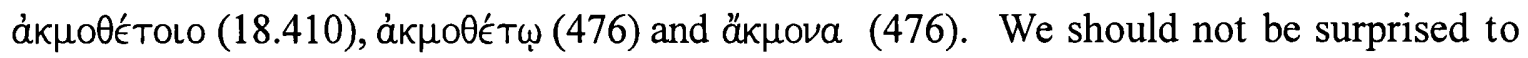
find that, when a chain is used by Zeus to punish Hera, an anvil is present as well.

As chains are exclusively manufactured by Hephaestus, the golden chain of Hera would also have been forged by him. Zeus could easily get a set of chains and anvil from the house of Hephaestus, even though Hephaestus might have forged them for another purpose. I suggest, then, that Hera was tied and suspended by a chain made by her own son. Zeus had hurled Hephaestus from heaven when Hephaestus tried to help Hera (Il. $1.590-1) .{ }^{24}$ The Iliad does not specify what kind of help Hephaestus offered; however,

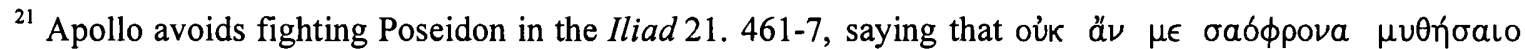

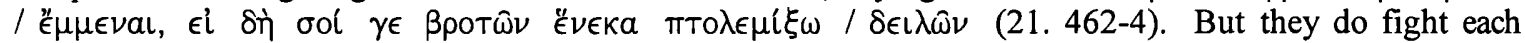
other in Il. 20. 54-74; 21. 342-520. Cf. Chapter III, Section 3 below.

${ }^{22}$ O'Brien (1993) 100. Also Willcock (1984) ad loc. comments that this is a similar form of punishment to that of the Roman slave, hung with heavy weights on his feet as in Plautus' Asinaria 301-5.

${ }^{23}$ West (1966) ad Theog. 722 suggests that åk $\mu \omega \nu$ is a meteorite. He points out that an åk $\mu \omega \nu$ is made of bronze, while meteorites are a compound of iron, nickel and stones, but at an earlier stage, they surely

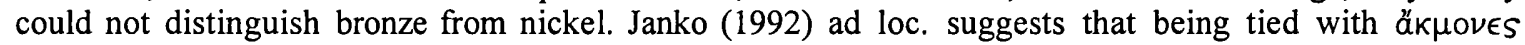
means that Hera is lashed by thunderbolts, which was what meteorites were thought to be.

${ }^{24}$ Or Hephaestus might have tried to stop Zeus from punishing Hera. In Book 18, Hera is responsible for the fall (18. 396). Braswell (1971) 20 suggests that the story in book 1 came from some pre-Homeric
} 
as he is the god of forging, we might suggest that he was forging a chain for the purpose of binding Zeus. If Zeus, instead, took Hephaestus' chain and bound Hera, fastening the anvils which lay beside the chain to add extra weight, this would certainly be both the most severe and most appropriate punishment for mother and son.

When gods are released from binding, it is their custom to present Zeus with valuable gifts. The Cyclopes showed their gratitude by presenting Zeus with the thunderbolt (Theog. 501-5) which became the indispensable instrument for his victory. The Hekatoncheires offered to fight against the Titans, rendering powerful assistance to Zeus (Theog. 652-63). Prometheus, in return for his liberty, revealed the secret of Thetis' son (Aeschylus P.D. 209-10). ${ }^{25}$ These rewards were crucial for securing Zeus' sovereignty.

According to Alcaeus (349 L.-P.), even Hera offered rewards. When she was trapped in the chair with hidden bonds inside it, sent by Hephaestus, Dionysus successfully brought Hephaestus to release her. ${ }^{26}$ In gratitude, Hera persuaded the other gods to admit Dionysus to Olympus as one of the Twelve. Hyginus (Fab. 166) records the tale that, for releasing Hera, Zeus awarded Hephaestus the hand of Athena. ${ }^{27}$

myth, and Homer invented (or modified) the story in Book 18 in order to make Thetis the rescuer, thus providing her with a claim on Hephaestus.

${ }^{25}$ The release of Prometheus is not made clear in the Theogony. Hesiod does not say that Heracles released Prometheus from chains, but only that he killed the eagle (527). Prometheus is still bound in 616. For further discussion see West (1966) ad 523-33.

${ }^{26}$ In this version of the myth, Hephaestus was crippled at birth. Hera was disgusted with him, and threw him down from heaven into the sea. After staying in the sea with the Nereids for years, and developing his skills, Hephaestus sent his mother a chair with hidden bonds. See further Pind. fr. 283; Paus. 1.20.3.

${ }^{27}$ As the picture on the François Krater (Florence, Mus. Arch. 4209) shows, Aphrodite might have been the reward, instead of Athena, because Aphrodite emerges at the centre of the composition in front of Zeus. See further Gantz (1993) 75-6. Hera also offers a chair, which was made by Hephaestus, as the reward to Hypnos (Il. 14.267-8) and, after his refusal, she persuades him by promising the hand of the Grace (Charis), Pasithea (Il. 14.267-8). This arrangement has interesting connotations, since the Charites are the 
A new restoration of the fragment of the Homeric Hymn to Dionysus ${ }^{28}$ has lately been proposed by M.L. West. ${ }^{29}$ This fragment offers the story of Hera's release from Hephaestus' chair. According to West's restoration, all 25 lines of the papyrus form a single speech, addressed by Zeus to the immobilised Hera. ${ }^{30}$ Lines $18-22$ are as follows:

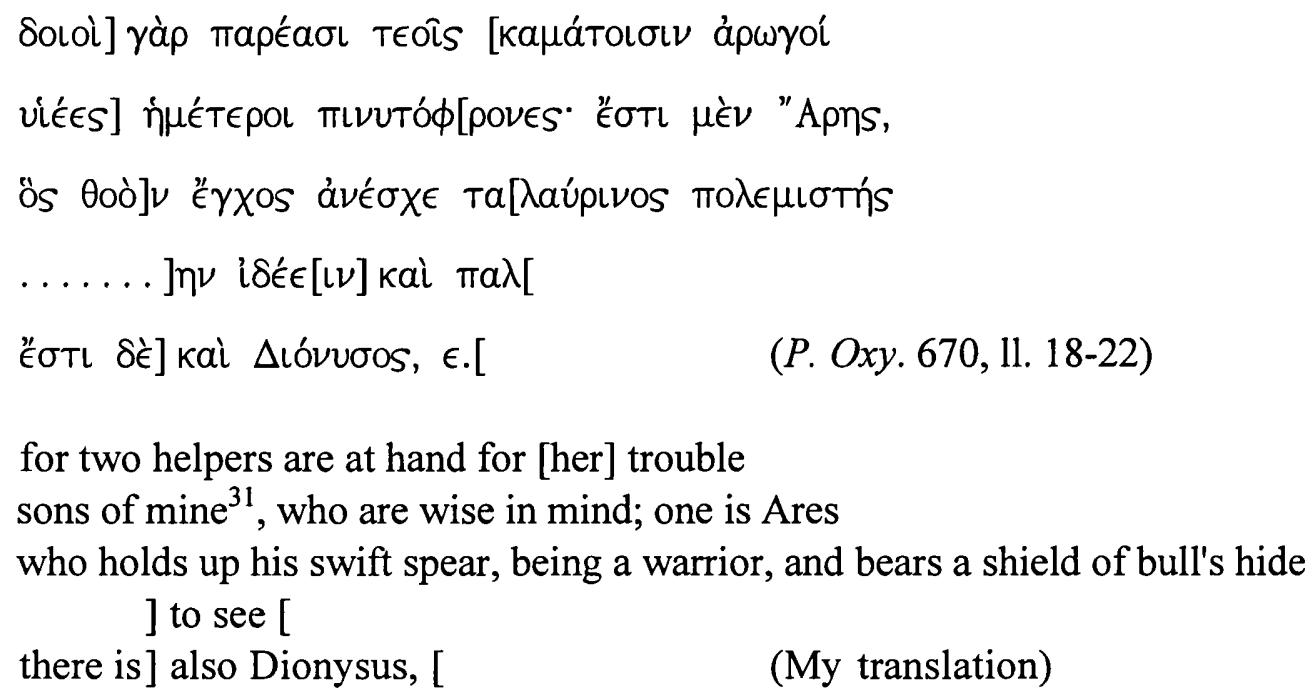

West suggests that mapéaol (18) refers to Ares and Dionysus as available helpers for Hera in her suffering, and Zeus encourages Hera, intimating that there are two able young gods at hand. ${ }^{32}$ This fragment corroborates Zeus' intervention in rewarding the release of Hera from Hephaestus' chair.

handmaidens of Aphrodite. For the interrelation between Hephaestus and Hypnos with a chair and the marriage to a goddess as the rewards, see Janko (1992) ad 14.256-61.

${ }_{28}$ P. Oxy. 670, ed. Grenfell and Hunt.

${ }^{29}$ West (2001b) 1-11.

${ }^{30}$ West (2001b) 5.

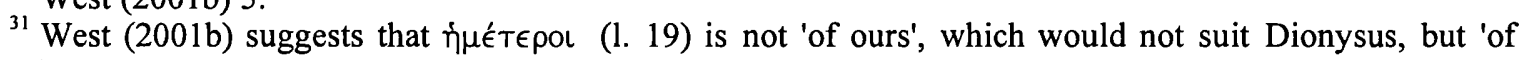
mine', which is a frequent Homeric use.

${ }^{32}$ West (2001b) 6. 
The Iliad does not explicitly mention the release of Hera from the golden chain, nor does it describe rewards for this deed. However, immediately following the account of the golden chain, the main narrative does hint at these events. I refer to Poseidon's obedience to Zeus:

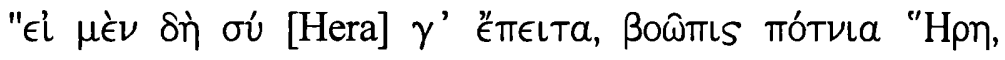

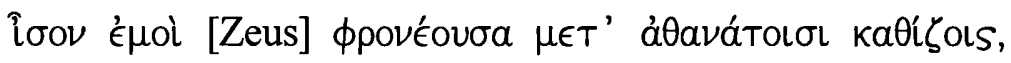

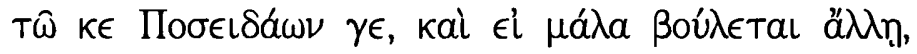

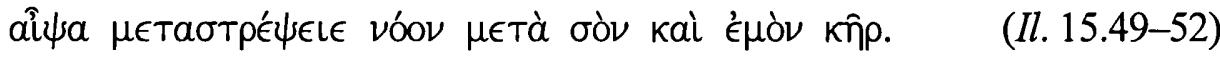

"Well, if from now on, ox-eyed queen Hera, you take your seat among the immortals with your thoughts the same as mine, then Poseidon, however contrary his wish, would quickly bend his purpose to follow your mind and my mind.

(Tr. M. Hammond)

This passage fits well with the context, because Poseidon's intervention to help the Achaeans was prominent from Book 13 onwards. If we look at the construction of the two narratives of the occasions when Zeus slept, in books 14 and 15 , we see that this passage functions as the conclusion for both accounts:

(a) The story told by Hypnos (14.242-62) and by Zeus (15.18-28) runs as follows:

1. The conquest of Troy by Heracles (14.250-1; also 5.638-42);

2. Zeus' sleep (14.252-3);

3. Hera's contrivance to drive Heracles to $\operatorname{Cos}(14.253-6 ; 15.26-8)$;

4. Zeus' punishment of the gods (14.256-7) and of Hera (15.18-20).

(b) The main narrative from book 14 onwards is: 
1. The defeat of the Greeks (14.1-152);

2. Zeus' sleep (14.346-51);

3. Hera's contrivance to defeat the Trojans (14.378--507);

4. Zeus' threat to Hera (15.14-33);

5. Hera's assurance to Zeus that she would advise Poseidon to be loyal in future (15.34-52).

Since the two stories (a) and (b) run quite similarly from 1 to 4 , the final part 5 can be read as the result not only of the main narrative (b), but also of the past story (a). If so, in return for being released from the chain, Hera may have sworn obedience to Zeus and, by her authority, made Poseidon loyal to Zeus. It would mean a great deal to Zeus to obtain Poseidon's loyalty - a direct clash with Poseidon would be perilous to Zeus' sovereignty.

The unique nature of Hera's binding is also worth noting. Zeus usually punishes gods by hurling them from Olympus: so Hephaestus (1.590-1), Hypnos (by implication: 14.258), an undefined number of gods (15.22-4), and Ate (19.130). Or, if Zeus had wanted to destroy Hera completely, he could have smitten her with his thunderbolt and thrown her into Tartaros, as he did to Typhon (Theog. 853-68). Hera's binding is different from these types of punishment. Hurling from Olympus is a momentary event (even if the fall might take a whole day because of Olympus' great height, as at $I l .1 .592$ ), whereas hanging in the sky persists over time: it exposes the miserable figure to the other gods for a considerable time. As often happened in the Middle Ages, public hanging acts as a deterrent by presenting the punishment to the watchers. This is Zeus' intention: to 
punish Hera and, at the same time, to threaten the other gods who see her suffer. Thus does he demonstrate his overwhelming power to all those who might attempt to challenge him.

The first target of Zeus' threat is, again, Poseidon. While Zeus sleeps, Poseidon intervenes in the war with extraordinary eagerness (14.361ff.). When he first receives from Sleep the news of Hera's success, the narrative tells us,

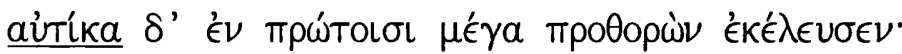

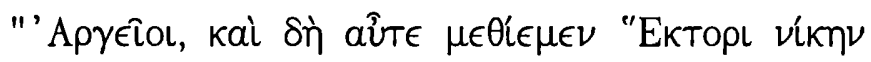

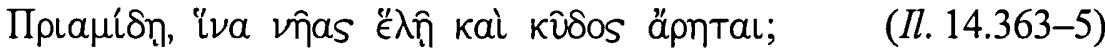

Immediately he leapt forward among the front-fighters and called loud to them: 'Argives, are we once more to yield the victory to Hector, son of Priam, so he can take our ships and win glory for himself? (Tr. M. Hammond)

The word aurika, at the beginning of the line, effectively presents his excitement. He knows that his leadership in the war will not last long - only, as Sleep suggested, 'for a

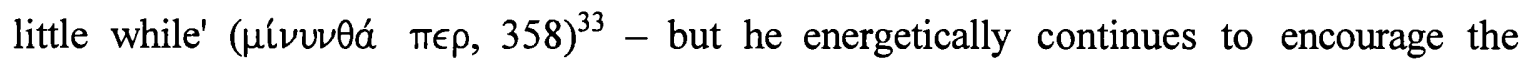
Achaeans until the end of book 14. Furthermore, Hera and Poseidon collaborate closely.

So it is quite natural that Zeus first sees Poseidon when he awakens from sleep (15.8). After mentioning the golden chain, the next thing that Zeus says concerns Poseidon:

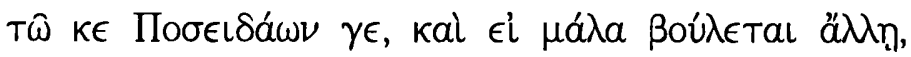




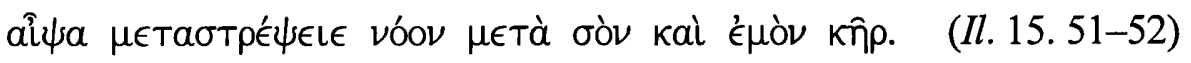

then Poseidon, however contrary his wish, would quickly bend his purpose to follow your mind and my mind. (Tr. M. Hammond)

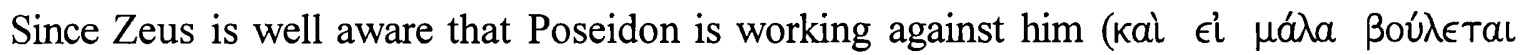

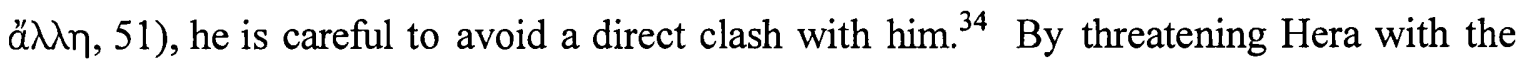
golden chain, he successfully manoeuvres her into appeasing Poseidon.

This dangerous tension between Zeus and Poseidon has been present in the narrative from the beginning of book 13. The juxtaposition of Zeus' perspective from Mount Ida (13.1-9) with that of Poseidon from the peak of Samothrace (13.10-6) brings into focus the serious tension between the two. ${ }^{35}$ Poseidon's frustrated inferiority is well represented:

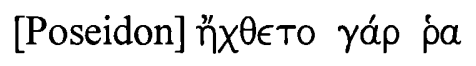

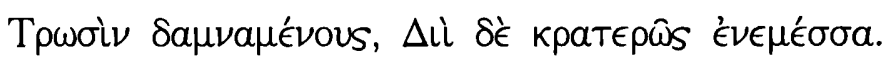

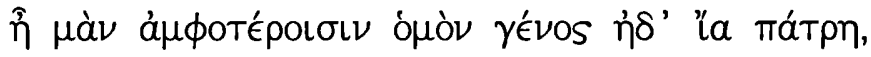

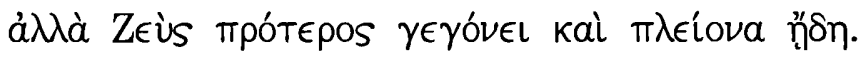

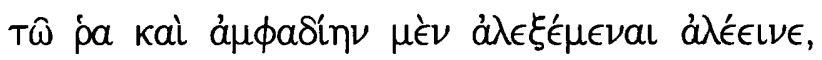

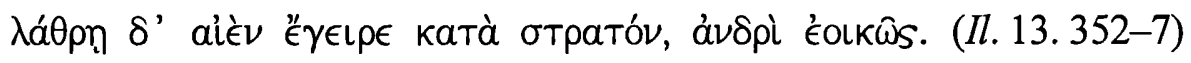

...he felt pain to see them broken by the Trojans, and furious anger at Zeus. Both these were indeed of the same descent and parentage, but Zeus was the older born and had wider knowledge. So Poseidon avoided giving open help, but went covertly up and down the army in man's shape, constantly rousing them to fight. (Tr. M. Hammond)

\footnotetext{
${ }^{33}$ I agree with Janko (1992) ad loc. that this phrase provokes suspense by making clear that his intervention cannot last.

${ }^{34}$ Janko (1992) ad loc.

${ }^{35}$ In the Titanomachy, too, the Titans are on high Othrys, and Zeus and other gods fight from Mount Olympus (Theog. 629-33).
} 
Although Poseidon is inferior to Zeus in age ${ }^{36}$ and knowledge (13.355), nevertheless, if he collaborates with Hera, he could cause serious problems for Zeus. Zeus' reference to the golden chain, therefore, effectively diminishes the threat offered by Hera and Poseidon.

The Iliad confines the antagonism between Zeus and Poseidon to the issue of which side they support in the human battle. However, this antagonism reflects a cosmic tension on a wider scale. Similarly, the golden chain of Hera, mentioned in order to check Hera's support for the Achaeans, reflects the broader cosmic struggle between the gods.

\section{Heracles: the motive for the golden chain}

We are told that Hera's punishment with the golden chain was provoked by the discovery that it was she who had contrived to send Heracles to Cos $(14.249-56 ; 15.18-30)$. According to later writers (Apollod. 2. 7. 1 and Plu. Mor. 304c-d), the story runs as follows: having sacked Troy, Heracles encountered a storm sent by Hera; driven to Cos, he was attacked, wounded and almost killed by the people there. From this crisis he escaped either because he was rescued by Zeus (Apollodorus), or because he hid in the house of a Thracian woman, in whose clothes he dressed himself and fled (Plutarch). Then, summoned by Athene, he went to Phlegra to fight against the Gigantes.

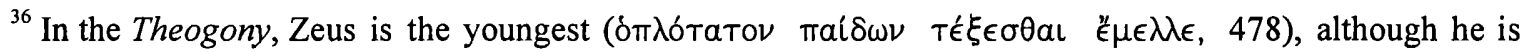
born first. The ambiguous relation between Zeus and Poseidon will be discussed in Chapter III.
} 
The Catalogue of Ships (Il. 2.676-79) records that Cos was the city of Euryalos. The fleet from Cos and the surrounding islands was led by Pheidippos and Antiphos, the sons of Thessalos, son of Heracles. ${ }^{37}$ In the Homeric Hymn to Apollo (42), Cos is described as the city of the people called Meropes. So, by the fifth century, the Meropes were regarded as the early inhabitants of Cos. The main settlement in the Mycenaean period was on the east coast of the island. ${ }^{38}$

A recently discovered papyrus fragment of the epic poem called the 'Meropis' ${ }^{39}$ has revealed more about Heracles' expedition to Cos. The papyrus, from the first century B.C., contains 24 lines of a local heroic epic with a commentary by the Hellenistic writer Apollodorus of Athens, the follower of Aristarchus, c. 150 - 125 B.C. A Hellenistic date has been suggested for the epic, ${ }^{40}$ but it seems more likely to date from the seventh or sixth century $\mathrm{BC} .^{41}$

In this poem, Heracles is nearly killed by Asteros, one of the Meropes (vv. 1-7);

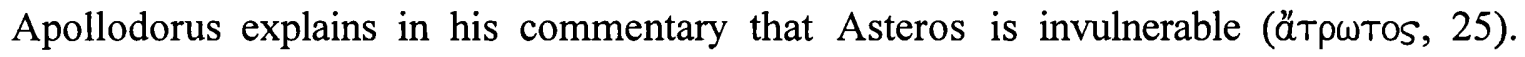
However, Athena comes to Heracles' aid and kills Asteros with her spear (vv. 8-17) and, after stripping and drying it, uses Asteros' strong skin for her aegis (vv. 18-24).

\footnotetext{
${ }^{37}$ These Homeric genealogies fit well with the legendary accounts of Heracles' activities: Heracles' son Tlepolemos of Rhodes and his grandsons Pheidippos and Antiphos of Cos fight against Laomedon's son Priam and grandson Hector. See further Craik (1980) 165.

${ }^{38}$ Sherwin-White (1978) 48.

${ }^{39}$ P.Köln III 126. Lloyd-Jones \& Parsons (1983) 406-7. The epic is quoted in a fragment of Apollodorus' $\Pi \epsilon \rho i \quad \theta \epsilon \hat{\omega} \nu$.

${ }^{40}$ Sherwin-White (1978) $48 \mathrm{n}$. 96 suggests the Hellenistic date because, first, in line 42 the ancient

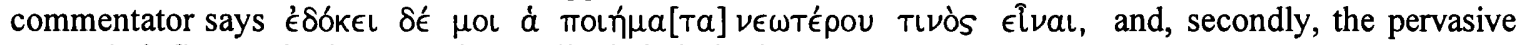
Homeric influence in the poem is a Hellenistic imitation.

${ }^{41}$ Janko (1992) ad 14.250-61. Lloyd-Jones (1984) 145-50 discusses the diction and style of the epic and concludes that it dates from the archaic period, pointing out that of $v \in \omega ́ \tau \epsilon \rho o l$ means, for ancient Homeric scholars, 'poets later than Homer'. Kramer et al. (1978) 24 suggest a date in the second half of the sixth century.
} 
According to Apollodorus, she considers that the skin will be useful for other dangerous situations (35).

As is suggested by the episode in which Asteros' skin forms Athene's aegis, the Meropes are not ordinary humans but are Gigantes. ${ }^{42}$ Philostratus (Heroicus 8.14)

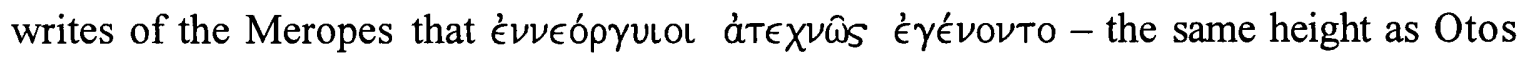
and Ephialtes (Od. 11.311-2). Fragment 637 of Aristotle (schol. to Aristides Panathenaicus 189.4) records that Asterios was a giant who was killed by Athena. ${ }^{43}$

The salient part of the Meropis fragment, for us, is its mention of Athena's intervention:

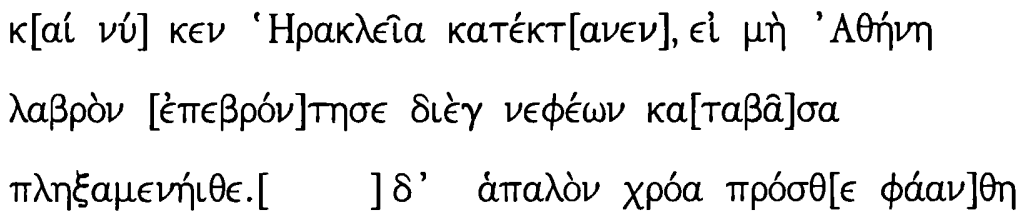
(903A L.-P. vv. 8-10)

he would have killed Heracles, if Athena had not thundered furiously, coming down through clouds, and struck [ ] tender skin ... she appeared in front (My translation)

Lloyd-Jones compares Il. 8.131-4, where Zeus helps the Trojans: ${ }^{44}$

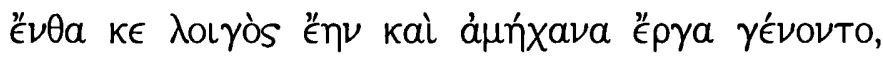

\footnotetext{
${ }^{42}$ For the Meropes as the Gigantes, see Janko (1992) ad 14.250-61.

${ }^{43}$ Janko (1992) ad 14.250-61 holds that Asteros must be the same as Asterios. Propertius 3.9 .48 also mentions that the people of Cos are giants: te duce vel lovis arma canam caeloque minantem/ Coeum et Phlegraeis Eurymedonta (Oromedonta, NFL) iugis. (Be thou my leader, then will I sing of the arms of Jove, of Coeus threatening heaven and Eurymedon: tr. H.E. Butler).

${ }^{44}$ Lloyd-Jones (1984) 144. He also refers to Il. 5.311-2, where Aphrodite protects Aeneas from the attack by Diomedes.
} 


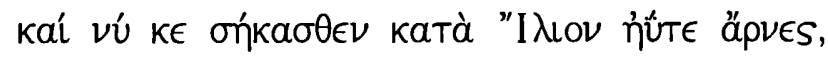

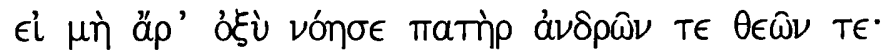

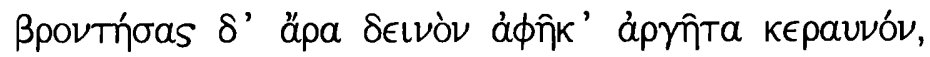

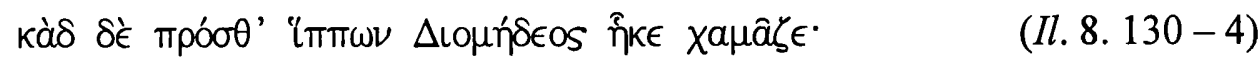

Then there would have been havoc and doings beyond all remedy, and the Trojans would have been penned back in Ilios like lambs, if the father of men and gods had not quickly seen it. He thundered fearfully, and let fly a vivid lightning-bolt, and hurled it to the ground in front of Diomedes' horses. (Tr. M. Hammond)

As Kirk points out, this passage is one example of an abrupt change of direction, characterised by vivid expression. ${ }^{45}$ The effect of this sophisticated narrative technique is to heighten a present moment and to shift the course of the narrative immediately. ${ }^{46}$ Similarly, the Meropis passage is impressive: Athena's fierce and dynamic movement is effectively depicted. Such an emphatic description seems to indicate that her intervention is the indispensable factor in this epic, just as is that of Zeus (Il. 8. 130-4) and Aphrodite (Il. 5. 311-7) in the Iliad. Athena intervenes in order to save Heracles and to gain her own fame in the war, which is supposed to be one of the main themes in the epic.

Heracles' subsequent expedition to Phlegra is not narrated in the extant fragment of the Meropis, but a fragment of the Catalogue of Women (fr. 43a M.-W.) offers further information. After narrating the genealogy of the rulers of Cos from Poseidon to Antagoras (55-60), the fragment states that Heracles sacked the city of Antagoras on his way home from Troy, and that he killed the arrogant Gigantes at Phlegra:

\footnotetext{
${ }^{45}$ Kirk (1990) ad loc.

${ }^{46}$ Louden (1993) 182-4 calls this type of Homeric narrative technique (i.e. 'and now X would have happened, had not $Y$ intervened') 'pivotal contrafactuals', and he analyses its advantages as (a) emphasising the change of direction of the plot; (b) heightening the narrative in various ways by additional means of emphasis; (c) making an editorial comment on a particular character.
} 


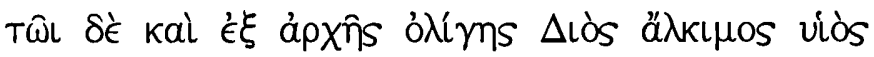

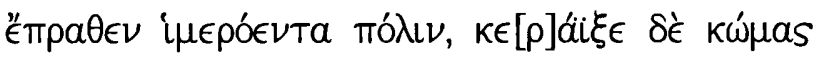

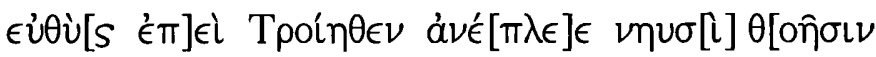

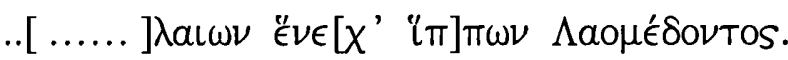

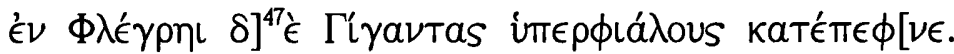

(Hes. fr. 43a M.-W., 1l. 61-5)

so from a small beginning the brave son of Zeus

destroyed the lovely city, and ravaged the villages

straight after he sailed away from Troy in his swift ships

] for the sake of the horses of Laomedon.

In Phlegra] he killed the overbearing Gigantes. (My translation)

If verse 65 is genuine ${ }^{48}$ it provides us with important information. After his exploits on Cos, Heracles went to Phlegra to fight the Gigantes. This explains why Athena intervened in the war with the Meropes: she (and the other gods) needed Heracles in the war against the Gigantes, so she had to save him when he was nearly defeated.

Pindar mentions Heracles' battle against the Gigantes several times, and in Nemean 4.25-7 and Isthmian 6.30-3, he mentions Heracles' role, in the same order, in his sack of Troy, his battle against the Meropes of Cos, and against the giant Alkyoneus: ${ }^{49}$

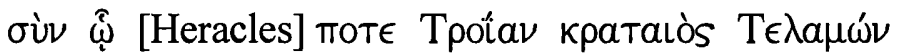

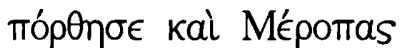

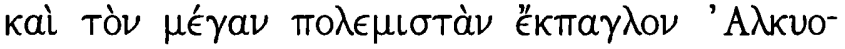

\footnotetext{
${ }^{47}$ The supplement of Merkelbach.

${ }^{48}$ After 65, the poem immediately changes the subject to Mestra and Sisyphos. Since there is no link to what precedes or follows, Gantz (1993) 446 suggests that the whole of line 65 might be an interpolation. However, the transition is not unacceptable.
} 
With him strong Telamon once spoiled Troy and the Meropes, And the huge warrior, horrible Alkyoneus (Tr. C.M. Bowra)

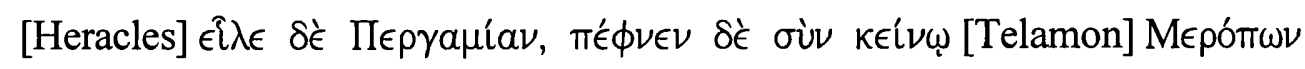

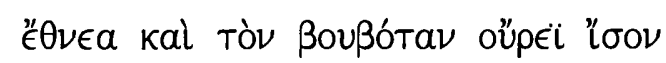

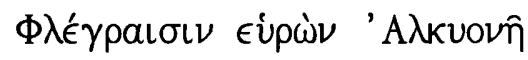
(Isth. 6.31-4)

He took Pergamos' city, and with Telamon killed The breed of Meropes, and the herdsman like a mountain, Alkyoneus, whom he found at Phlegrai (Tr. C.M. Bowra)

Nemean 4.25-7 does not mention the location of Heracles' battle with Alkyoneus; but Isthmian 6.31 explicitly states that the hero met Alkyoneus at Phlegra. Furthermore, Nemean 1.67-9 offers the information that the Gigantomachia in which Heracles joined with the gods was at Phlegra:

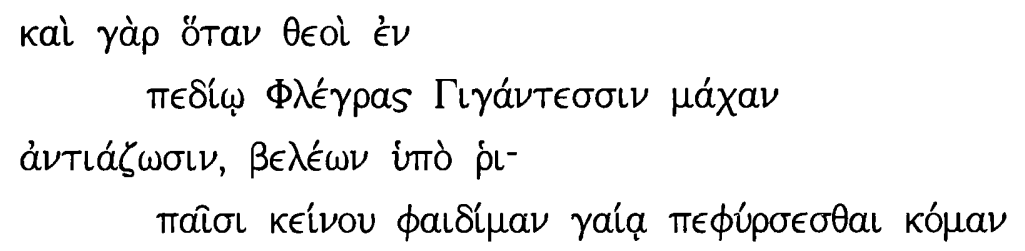

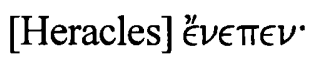

(Nem. 1.67-9)

For when on Phlegra's plain

The Gods meet the Giants in battle

Bright hair shall be fouled in the dust

Under the gale of his arrows, '

He told: $\quad$ (Tr. C.M. Bowra)

${ }^{49}$ Janko (1992) ad 14.250-61. Pindar also mentions that Heracles conquered the Gigantes (Nem. 7.90). 
The repetition of the same information, in the same sequence - Heracles' expeditions to Troy, to Cos (fighting against the Meropes), and then to Phlegra (fighting against the Gigantes with gods) - proves that these events were a well-established part of Heracles' legend.

Apollodorus offers a similar story in the final part of his account of Heracles' campaign on Cos (Bibl. 2.7.1): Heracles came to Phlegra, where he fought with the gods against the Gigantes. These accounts offer us the outline of the story of Heracles on Cos and after Cos: he was sent to Cos by Hera, where he fought the Meropes; almost defeated, but saved by Athena, he went to Phlegra to fight the Gigantes.

We must now recall the curious role of Heracles in the war against the Gigantes. A scholion to Pindar's Nemean 1.101 informs us of his contribution to the war:

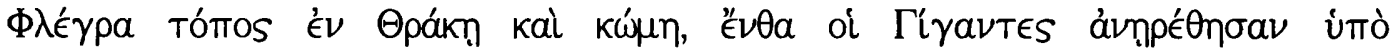

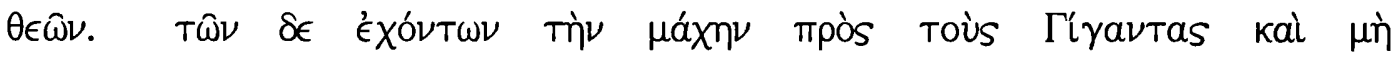

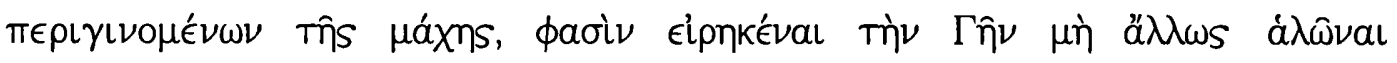

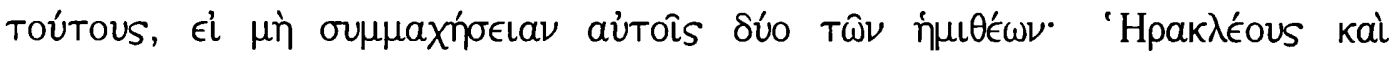

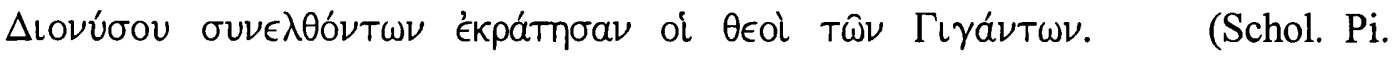
Nem. 1.101)

Phlegra is a place and a village in Thrace, where the Gigantes were defeated by the gods. When the gods were engaged in battle with them, and could not prevail over the Gigantes, they say that Gaia announced that the Gigantes would not be conquered unless two of the hemitheoi should fight as the gods' allies. Heracles and Dionysus therefore joined the battle, and the gods were victorious.

(Tr. T. Gantz) 
Apollodorus (Bibl. 1. 6. 1) offers a similar story: the gods received an oracle stating that none of the Gigantes could perish at the hands of the gods, but they would be destroyed with the help of a mortal. So, Zeus summoned Heracles by means of Athena:

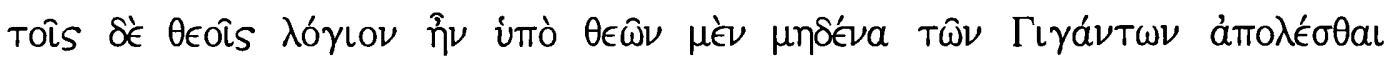

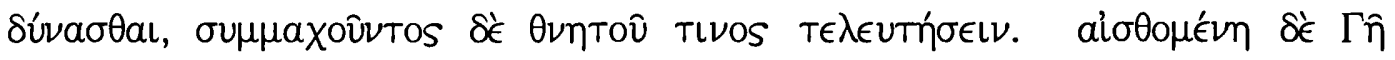

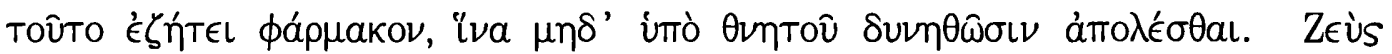

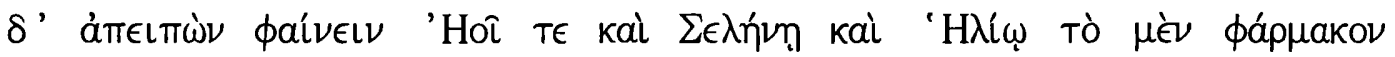

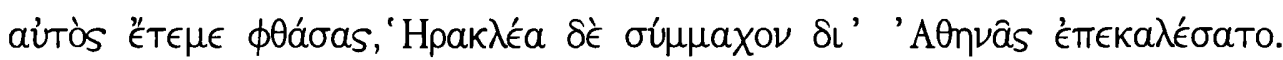

(Bibl. 1.6.1)

Now the gods had an oracle that none of the giants could perish at the hand of gods, but that with the help of a mortal they would be made an end of. Learning of this, Earth sought for a simple to prevent the giants from being destroyed even by a mortal. But Zeus forbade the Dawn and the Moon and the Sun to shine, before anybody else could get it, he culled the simple himself, and by means of Athena summoned Heracles to his help.

(Tr. J.G. Frazer)

It is clear from these accounts that Heracles' intervention in the war against the Gigantes was crucial. This is why he was helped by Athena on Cos, and was taken to the battle against the Gigantes. This explains why it was to Cos that Hera sent Heracles: Hera attempted to render him unable to join the war. The traditional story pattern holds that Hera persecuted Heracles out of jealousy; but another story can perhaps be seen behind Hera's hostility to Heracles, if we read this story in the light of the Gigantomachy. Had her plan been successful, Zeus would have been defeated by the Gigantes, and it could be for this treachery that Zeus punished her by binding her with the golden chain.

The Iliad states that Hera's plot against Heracles resulted in the harsh punishment of binding. Heracles' status as the beloved son of Zeus is offered as a reason for the 
severity of the punishment. We can, however, suggest further cause for a punishment which appears overly stringent merely for diverting a mortal off his course -- even though Zeus' punishments were sometimes disproportionate to the crimes. I suggest that this harsh punishment would be appropriate for an attempt to overthrow Zeus' sovereignty. Therefore, I conclude that Hera's dispatch of Heracles to Cos could have been intended to hinder him from joining the Gigantomachia, which, had it been successful, would have seriously endangered the sovereignty of Zeus. This is why Hera received that most grave and shameful punishment.

Gaia gives birth to the Gigantes because of her anger over the treatment of the Titans (Apollod. Bibl. 1.6. 1). When we think about the relationship between Hera and Gaia, we conclude that Hera would favour the side of Gaia and the Gigantes in the war. The close link between Hera and the Gigantes is confirmed by a scholion:

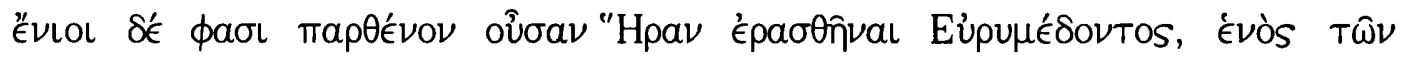

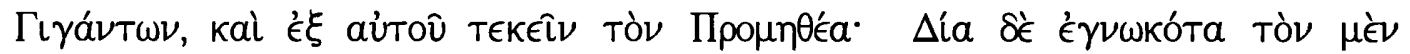

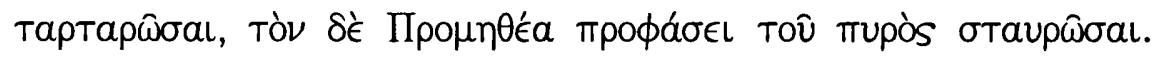

(Schol. T ad Il. 14. 296)

Some say that Hera, when she was a maiden, fell in love with Eurymedon, one of the Gigantes, and by him bore Prometheus. Zeus, knowing this, hurled Eurymedon into Tartaros, and on the pretext of the stolen fire, chained up Prometheus.

(My translation) 
It is true that a variant version makes Eurymedon a rapist, ${ }^{50}$ but we cannot be certain that the virgin Hera would be a maidenly victim in the manner of human virgins. We see that Hera has three reasons for supporting the Gigantes: (a) the Gigantes originate from Gaia, with whom Hera is closely linked; (b) one of the Gigantes was Hera's lover in one version of the myth; and (c) the Gigantes could overthrow Zeus if only Heracles were prevented from joining the war. Hence Hera, aware of the future role of Heracles in the war, attempted her unsuccessful plot against him.

Apollodorus (Bibl. 1. 6. 2) gives a list of the gods who fight against the Gigantes; for example, Ephialtes is killed by Apollo, Eurytus by Dionysus, and Clytius by Hecate. Poseidon is mentioned close to the end of the list, where he is said to chase Polybotes through the sea to Cos, and then to throw a massive piece of the island onto him, which became another island, Nisyros. ${ }^{51}$ There is no account of the Gigantomachia that makes him fight against the gods. However, in view of what seems to have been a long history of his rivalry with Zeus, he would not have been an implausible accomplice of Hera.

One episode in the lliad shows that he is an ambiguous figure. In spite of his frequent support of the Achaeans, we recall that he once built the walls of Troy (Il. 7.452-3; Il. 21.441-57). ${ }^{52}$ The Iliad gives no reason for this ambiguity, but a scholion reports that Poseidon was forced to build the Trojan wall as a punishment from Zeus:

\footnotetext{
${ }^{50}$ Dindorf (1875) ad 14.295 (MS A) records this variant: Eurymedon raped Hera while she was still being

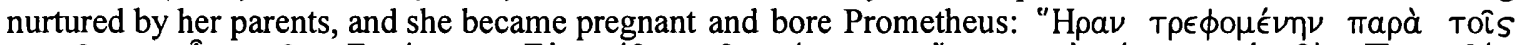

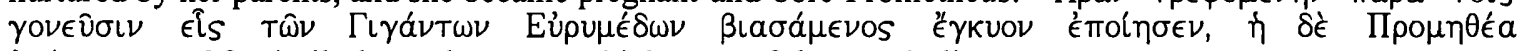
$\epsilon^{\prime} \gamma \gamma \epsilon \dot{\epsilon} \nu \eta \sigma \epsilon \nu$. Cf., similarly, Helmut van Thiel's text of the D-scholia.

${ }_{52}^{51}$ Strabo (10.5.16) offers two versions of the death of Polybotes: he lies beneath either Nisyros or Cos.

${ }^{52}$ At 7.452-3, Poseidon says that he and Apollo built the Trojan wall, while at 21.448-9 Apollo tended Laomedon's herds. Kirk (1990) ad 7.443-63 comments that 7.443-63 is an addition, developed not by
} 


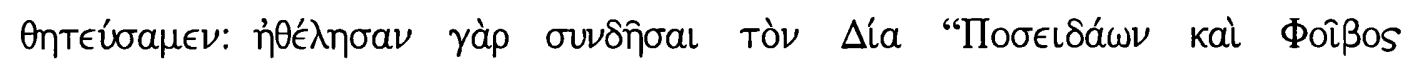

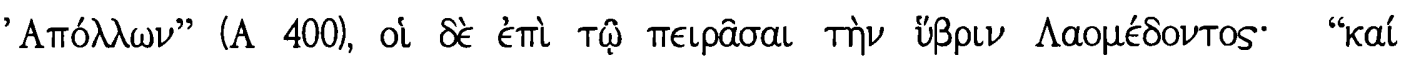

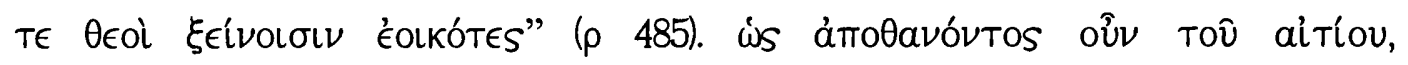

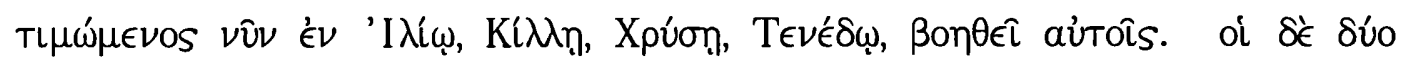

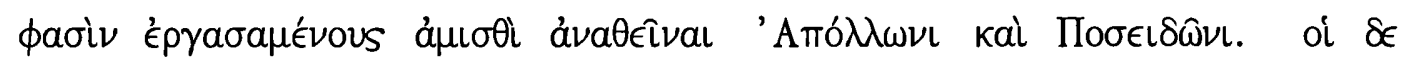

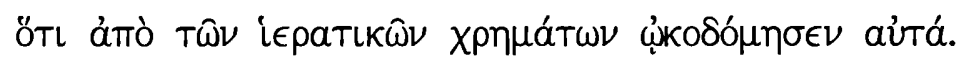

(Schol. T ad Il. 21. 444)

"We laboured": for Poseidon and Phoebus Apollo (Il. 1. 400) wanted to bind Zeus, but some say, [they laboured] in order to test the insolence of Laomedon; "and the gods pretend to be strangers" (Od. 17. 485). As the guilty party was dead, Apollo, now being honoured in Ilios, Killa, Chryse and Tenedos, helps them. Some say that "two working without a pay" refers to Apollo and Poseidon, but others say that [Laomedon] built these [walls] from sacred funds.

(My translation)

The scholiast, who gives no source, explains Poseidon's work by reference to the story of Zeus' binding at Iliad 1. 400, where Poseidon is one of the three gods who tries to bind him. Although the attempt to bind Zeus was unsuccessful, the reference provides important evidence of Poseidon's antagonism toward him.

The chthonic nature of Poseidon's offspring in the Theogony, the Homeric Hymns and the scholia to the Iliad may also assist in explaining his antagonistic attitude to Zeus. According to the Theogony, Poseidon married Medusa, who bore him two sons Pegasus and Chrysaor (278-81). The scholia offer the story of Poseidon's mating, in the form of a horse, with a Harpuia (schol. T ad Il. 23.347) or with an Erinys (schol. Ab ad Il. 23.346

Homer but by another doofós. However, I agree with Richardson (1993) ad 21.441-57 who suggests that it is hardly a serious contradiction. 
and schol. T ad Il. 23.347). The Erinys is named Tilphossa or Telphusa, ${ }^{53}$ whose spring is buried beneath stones by Apollo in the Hymn to Apollo (375-87). The fleet horse Areion is born from the spring Telphusa - so the myth of Poseidon-Telphusa-Areion repeats the myth of Poseidon-Medusa-Pegasus. ${ }^{54}$ The Hymn to Apollo (231-8) and the Hymn to Hermes (186) mention Poseidon's sanctuary at Onchestus, which had a specific association with horses. ${ }^{55}$ Polyphemos is his son by Thoösa (Od. 1.68-73), and Otos and Ephialtes are his sons by Iphimedeia. Poseidon, who has such chthonic offspring, has another reason for opposing the power of Zeus. ${ }^{56}$

The story of the golden chain of Hera (15.16-28) and that of Hephaestus' hurling from Olympus (1.590-3) clearly describe the same incident. ${ }^{57}$ If we take this incident together with the war when Ares was bound by the monstrous twins (Otos and Ephialtes), we can construct a hypothetical outline of the Gigantomachia. ${ }^{58}$ The war takes place at Phlegra, Eurymedon being the king of the Gigantes (Od. 7.58-9). Otos and Ephialtes bind Ares (Il. 5.385), and almost succeed in ascending to Olympus (Od. 11.3136). Hera, knowing Gaia's prophecy about Heracles' role in the fighting (schol. P. Nem.

\footnotetext{
${ }^{53}$ Fontenrose (1959) 367 n.3 gives several forms of Telphousa's name: Telphus(s)a, Tilphus(s)a, Tilphos(s)a, Telphusia, Thelpusa, Tilphos(s)ia.

${ }_{54}^{54}$ Fontenrose (1959) 395: Heracles used this horse, Areion, in his race with Kyknos.

${ }^{55}$ The custom at Onchestus is unclear. AHS (1936) ad Hy. Apol. 231-8 gives several explanations such as the custom of 'a rule of the road' or the horse-race. Janko (1986) 43 refers to the scholion to Aspis 105, which explains Poseidon's epithet taúpeos from the sacrifice of bulls in Onchestus.

${ }^{56}$ Other evidence of Poseidon's chthonic nature: Ge (Chthonia) and Poseidon once held the oracle in partnership in Delphi; and, beside the altar of Poseidon in Apollo's temple in Delphi, is the hearth altar, called eschara or hestia, which is associated with the worship of heroes and chthonic powers. See further Fontenrose (1959) 394, 397.

${ }_{58}^{57}$ Whitman (1970) 37-9, followed by Richardson (1975) 70-1; and O'Brien (1993) 101.

${ }^{58}$ O'Brien (1993) 101-3 suggests that the battle in which Hera and Hephaestus formed an alliance was against a river god (21.331-41). However, her interpretation does not fit - the account in the Iliad is that Hera was punished for her contrivance against Heracles. Moreover, it is unthinkable that Hera and Hephaestus would have received such punishment after a battle against a river god who does not seem to concern Zeus seriously.
} 
1.101), sends him to Cos in order to prevent him from joining the war (Il. 14.249-56, 15.18-30). On Cos, Athena saves him when he is nearly killed by the Meropes ('Meropis' vv. 8-9) and takes him to Phlegra (Hes. fr. 43a M.-W. 1. 65). With the decisive help of Heracles, the gods win the war and Eurymedon and the Gigantes are destroyed (Od. 7.60). As a punishment for her dispatch of Heracles, Zeus binds and hangs Hera (Il. 15.16-28), probably with the chain that Hephaestus forged, and hurls Hephaestus from Olympus (Il. 1.590-3).

Some scholars doubt whether Homer knew the legend of the battle of the Gigantes against the gods, and claim that the whole tale of the Gigantomachia was invented. ${ }^{59}$ However, the poet's mentions of the war, scattered and scanty as they are, undoubtedly indicate that the legend was pre-Homeric and known to the poet. Moreover, the consistency of these accounts clearly shows that they belong to a lost work of the epic tradition, the Gigantomachy; as Janko remarked, 'the poet in fact draws on an early gigantomachy or Heracleid. ${ }^{60}$

The existence of such a story is attested by two early witnesses. The first is Theogony 50-2:

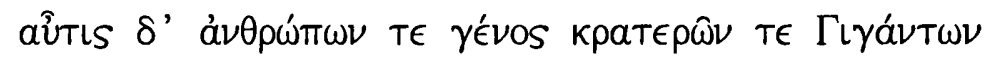

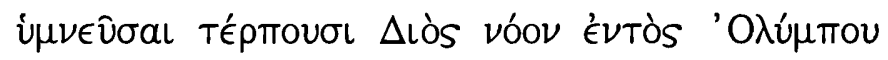

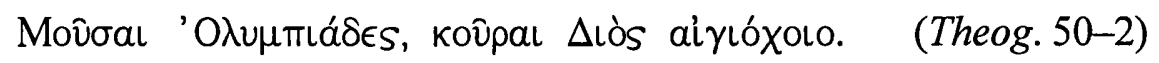

\footnotetext{
${ }^{59}$ For example, Stanford (1947) ad 7.59. Erbse (1986) 18-21 notes that the role of Hypnos in the Heraclean story (Il. 14.242-68) is an invention of the poet, but offers no conclusions as to the existence of the Gigantomachia.

${ }^{60}$ Janko (1992) ad 14.250-61.
} 
And again, they chant the race of men and strong Giants, and gladden the heart of Zeus within Olympus, - the Olympian Muses, daughters of Zeus the aegis-holder.

(Tr. H.G. Evelyn-White)

The second is fragment 1 of Xenophanes:

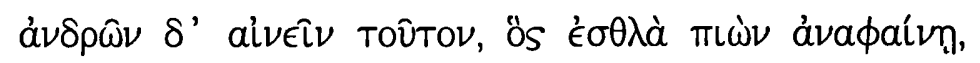

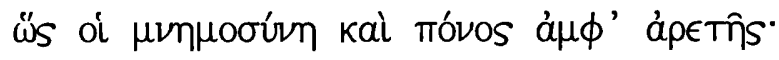

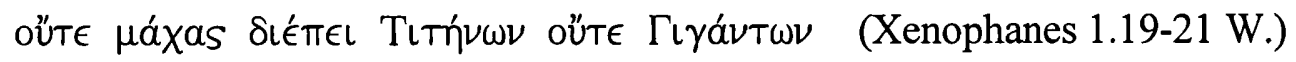

Praise the man who when he has taken drink brings noble deeds to light as memory and a striving for virtue bring to him. He deals neither with the battle of Titans nor Giants (Tr. J.H. Lesher)

The verses in the proem to the Theogony tell us that the Muses delight the mind of Zeus by singing of the race of men and the powerful Gigantes. This could be taken to suggest that such an epic did exist. ${ }^{61}$ In the fragment of Xenophanes, the poet includes the battle of the Gigantes as one of the topics which a noble man should avoid. This suggests that there was some sort of poem in existence at least by the time of Xenophanes in the latter half of the sixth century BC. The discovery of the fragment of the Meropis also confirms that such poems existed.

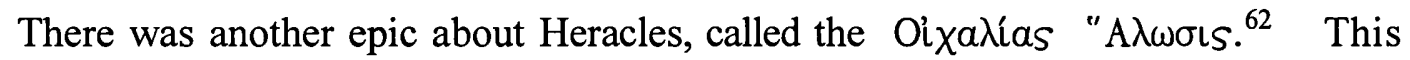
epic probably offered themes of suffering and labour. ${ }^{63}$ Nagy discusses a parallel

\footnotetext{
${ }^{61}$ West (1966) ad loc. leaves the problem open, noting that Hesiod may be imagining something like his own Myth of the Ages (109 ff.), where the bronze generation possess several characteristics shared with the Gigantes; but this view does not seem convincing.

62 ed. Allen (1912) 144-7.

${ }^{63}$ Huxley (1969) 105-6 gives a summary of this epic: Heracles defeats Eurytos, king of Oichalia, in an archery contest; he therefore claimed the promised prize, the king's daughter, Iole or Ioleia; when Eurytos refused to hand her over, Heracles sacked the city, slew Eurytos, and took Iole captive. Kreophylos of Samos was believed to be the composer of this epic, but his date is unknown.
} 
between this epic and the Iliad, namely the emphasis on mortality. ${ }^{64}$ If we did not know of the existence of the epics about Heracles - the Gigantomachia as well as the Meropis and the Oichalias Halosis, or the earlier versions of these epics - the expressive potential of Achilleus' words 'even Heracles could not escape death' (Il. 18. 119) would hardly be understandable. If this famous phrase could console the speaker as well as the listener, ${ }^{65}$ it seems that these Heraclean epics not only existed but also enjoyed wide currency in the Homeric period.

To conclude, behind the account of the golden chain of Hera lies, I have argued, the battle against the Gigantes. Heracles secured Zeus' sovereignty, and Hera was punished for her role as the ringleader of Zeus' challengers, among whom might have been Poseidon, as he is always a potential rival of Zeus, given the history of the division of domains between them. ${ }^{66}$ Having suppressed the story of Zeus's crisis in the Gigantomachia, the Iliad, instead, presents the story of the golden chain of Hera as a comical punishment for mischief. However, if Hera's treachery had succeeded, it would have posed a real threat to Zeus, as the grievous punishment of binding proves.

In failing, Hera falls under the control of Zeus, and he upholds the cosmic equilibrium. As O'Brien remarks, from a Panhellenic point of view, the lliad has more need of her than of others, since Panhellenism was not conceivable without subordination and hierarchy. ${ }^{67}$ Through this process, Hera has been degraded, and so too has the

\footnotetext{
${ }^{64}$ Nagy (1979) 165.

${ }^{65}$ Edwards (1991) ad loc.

${ }^{66}$ For the further discussion on the antagonism between Zeus and Poseidon, see Chapter III.

${ }^{67}$ O'Brien (1993) 174.
} 
impact of her rebellion. After the Iliad, we see Hera much less frequently. ${ }^{68}$ However, as I have demonstrated, the Iliad nevertheless preserves traces which suggest that Hera had once been a truly powerful goddess.

${ }^{68}$ Gantz (1993) 61. 


\section{Chapter III : The Reordering of the Universe}

This chapter provides a conceivable reconstruction of events which are, I suggest, merely glossed in the Iliad. Of course, my interpretation is only one among the plethora of alternatives that a close reading of such a complex work offers. Furthermore, I do not deny that my exploration will pressurize the text in the absence of adequate narrative closure to present one version of cosmic mythological interrelations.

Throughout the battles against the Titans (678-82, 695-705) and Typhoeus (83952), the image of cosmic disorder is emphasised. These battles are decided by the power of Zeus' thunderbolt, and his victory, therefore, symbolises a reordering of the universe. After the conclusion of this cosmic strife, Zeus' rule in the Iliad seems unassailable. However, the antagonism between the gods still resurfaces occasionally, intimating the rebellion which had existed in the recent past.

In the Iliad, hostility between the gods is characteristically expressed through the motif of protection: in the Achaean and Trojan armies, their various favourites act as their surrogates as they vie with each other on behalf of their benefactors. ${ }^{1}$ It is sometimes held that the myths of the battles between the gods serve as background to the human battle. Certainly the divine battles function as exemplars -- cautionary or rallying -- for their human counterparts; ${ }^{2}$ while these battles are individually contained, and recounted for their own sake, the partisanship and characterisation of the gods are consistent enough

\footnotetext{
${ }^{1}$ The Odyssey is quite different: harmony prevails in the council of the gods. Procedure in the council is quiet and orderly; however, they decide on Odysseus' return in the absence of Poseidon (Od. 1.22).
} 
to suggest that the poet of the Iliad refers to a particular rebellion such as the Gigantomachia.

Following the narration of the attempt to bind Zeus (1.396ff.), tension between him and the other gods becomes conspicuous, although it is sometimes set forth comically. In this chapter, I delineate the vestiges of an earlier epic of the gods' battle. Among the divine oppositions to Zeus, the alliance of Hera and Poseidon is the most often addressed (as I discussed in Chapter II). As Poseidon is the only male deity who explicitly challenges the power of Zeus in the Iliad, I will focus on him as (a) the ringleader in attempted coups against Zeus and (b) as the last obstacle to Zeus' reordering of the universe.

\section{The 'tug of war' between Zeus and Poseidon (Iliad 13.1-360)}

In book 13 of the Iliad, Zeus and Poseidon stretch the "rope of war" and pull alternately:

Toì $\delta$ '

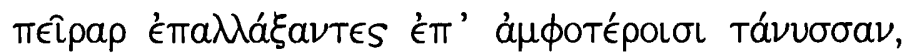

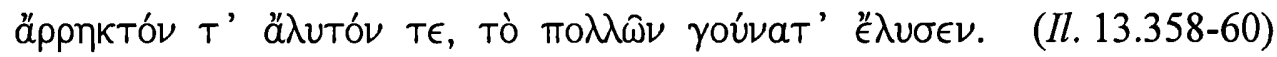

So those gods crossed and tied the ropes of hard conflict and levelling war over both armies, and stretched them taut, not to be slipped or broken - but they broke the strength of many men. (Tr. M. Hammond)

\footnotetext{
${ }^{2}$ For example, Nilsson (1925) 175-6 notes that the contests are consistently presented as deterrent examples.
} 
This rope metaphor symbolises that the human battle, as well as that of the two gods, is locked in stalemate. ${ }^{3}$ Behind this episode, I wish to propose that there were other stories in which Zeus and Poseidon tested each other's physical strength in single combat. Since binding represents the ultimate defeat for a god, this 'crossing and tying the ropes' carries great significance. I contend that this tug-of-war summons up a (serious) previous battle between these gods, and is not necessarily to be read merely as an entertainment for the human audience. An examination of the structure of the first half of book 13 of the Iliad will demonstrate the plausibility of this hypothesis.

The commencement of Book 13 emphasises the increasing tension between Zeus and Poseidon: the two gods sit on opposite mountain-tops, their mutual, exclusive loftiness suggesting a mounting and dangerous pressure. Zeus looks away from the battlefield (3-4), but Poseidon maintains an intense interest in the battle (où $\delta$ ' $\dot{\alpha} \lambda a 0 \sigma \kappa o \pi เ \eta े \nu, 10)$, which is emphasised by the double negative in this phrase; we read,

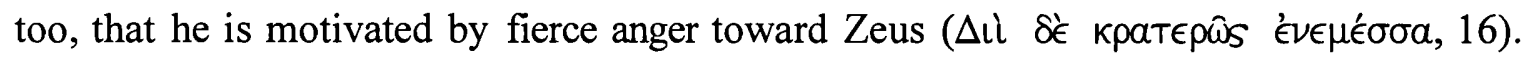
The narrative suggests that Poseidon will surely - stealthily and behind Zeus' back - join the war, which would provoke a direct clash. Although Zeus looks far over the land of the Thracians and Mysians, never suspecting that any of the gods would intervene in the human battle (3-9), attention is twice drawn to his shining eyes (ő $\sigma \sigma \epsilon \phi a \epsilon \iota \omega \omega ́, 3$ and 7). The repeated reference to his 'shining eyes' within a short interval implies that Zeus, too,

\footnotetext{
${ }^{3}$ Janko (1992) ad loc.
} 
feels the danger and anticipates a clash. ${ }^{4}$ These signifiers of antagonism cast ominous shadows over the beginning of book 13.

The following passages describe Poseidon's prodigious journey (17-22) and his majestic armour and horse (23-31)..$^{5}$ When he pities the Achaeans, Poseidon departs from his mountain-top on Samothrace to arm at Aegae at once (aủTíka, 17): aủTíka $\delta^{\prime}$ '̇ $\xi$

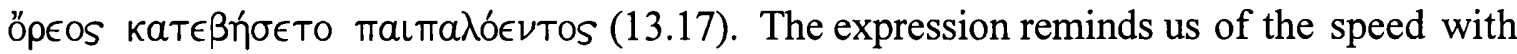
which he races to encourage the Achaeans while Hera seduces Zeus: aủtíka $\delta^{\prime} \epsilon^{\prime} \nu$

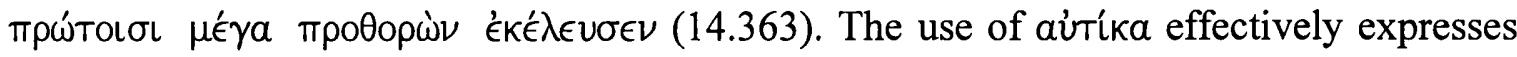
Poseidon's haste: whenever he desires to carry out his own plans, his time is short and limited. He can work only while Zeus looks away from the battlefield, ${ }^{6}$ because he knows that he is no match for Zeus, whose superior strength is repeatedly emphasised by Poseidon's own words (8.210) and by the narrative (13.355). What is significant is that, in spite of this recognition, Poseidon -- like Hera -- does not yield but persists in his attempts to challenge Zeus.

Poseidon's arming is described with care: the horse (23-4), armour (25) and whip (25-6). The same arming combination is repeated, later, in Achilles' preparation for joining the war: armour (19.369-86), horse (19.392-5), whip (19.395-6). ${ }^{7}$ The elaborate

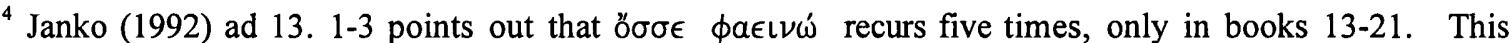
proves that the dangerous tension among the gods is increasing towards the theomachy in books 20-21. Cf. Section 2 and 3 of this chapter.

${ }^{5}$ I agree with Janko (1992) ad 13. 10-38 that the description emphasises Poseidon's purpose and the importance of his arrival, and expresses his three main attributes: earth-shaker, horse-god and sea-god.

${ }^{6}$ Cf. Chapter II, Section 2, n. 34.

${ }^{7}$ Compare the description of Athena's preparations at Il. 5.733-42 and 8.384-391. In both passages, armour, car (horses), and spear are mentioned. As these examples demonstrate, these description of arming can be regarded, on the one hand, as formulaic; but on the other hand, each episode has, in itself, a coherent artistic function. Janko (1992) ad 13.21-2 comments that here Poseidon's preparation stresses the
} 
description of Achilles' arming precisely fits the context: his rejoining the war is the point on which the whole plot of the Iliad turns. On the other hand, the overt grandiloquence which describes Poseidon's overly impressive arming appears ironic, since Poseidon does not actually fight in the war, but only encourages the Achaeans with words (at 47-58, to the two Aiantes; and, at 95-128, to Teucer and others). We might suspect that Poseidon's elaborate equipment would be more suitable for an individual battle against Zeus than for encouraging the human battle. In this we find another parallel with Achilles, who sets out for single combat with Hector. Reinhardt is correct to suggest that Poseidon arms like a hero for his aristeia. ${ }^{8}$

Poseidon's speeches to the Achaeans are constructed in such a way that, while they are aware of their own inferiority, they are nevertheless encouraged to fight and overthrow their enemy who has the advantage. His message is, of course, appropriate to their desperate situation, but it is also analogous to Poseidon's own circumstances: ${ }^{9}$ that is, while he admits his inferiority to Zeus, he still does not give up his challenge. Let us examine Poseidon's words to Teucer and others:

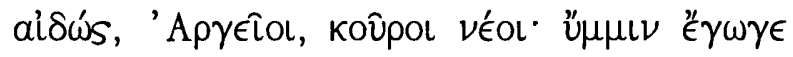

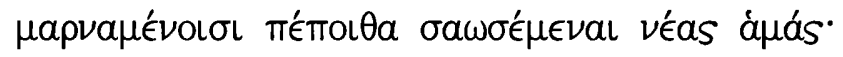

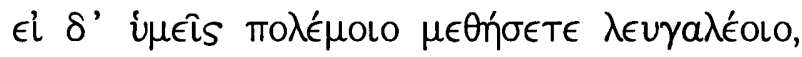

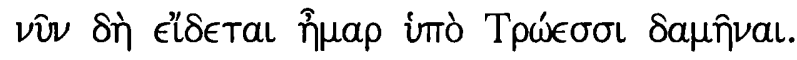

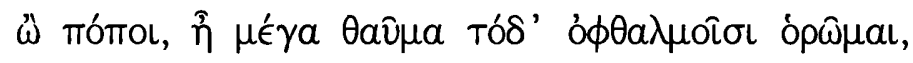

idea of imperishability; it also makes the scene glitter. I examine the significance of Athena's preparation in Chapter IV, Section 3.

${ }^{8}$ Reinhardt (1961) 279: "der Gebieter rüstet sich zu seinem Unternehmen wie ein Held zu seinen Aristie." 


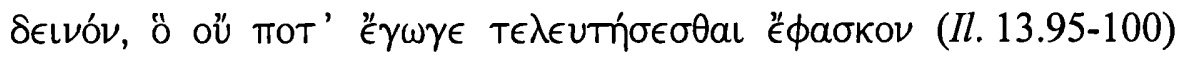

Shame, you Argives, mere boys! You are the ones I trust in to save our ships, if you will fight. But if you men hang back from the misery of battle, then the day of our crushing by the Trojans is now here to be seen. Oh, this is a great astonishment for my eyes, a fearful thing that I never thought would come about. (Tr. M. Hammond)

For Poseidon, the phrase kov̂pol véol (95) is particularly appropriate: he is considered an elderly deity among the Olympians; for example, he is older than Apollo, as he states in book 21:

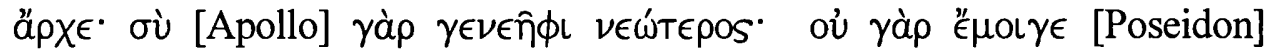

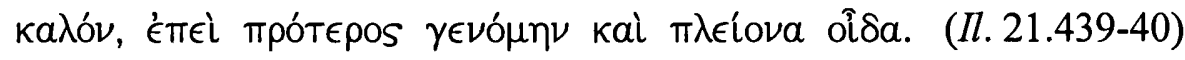

Begin, then, since you are the younger - it would not be fair for me to start, as I was born older than you and have greater knowledge. (Tr. M. Hammond)

Although Poseidon addresses himself to the younger Achaeans in book 13, such encouragement would be similarly appropriate for Poseidon to use in addressing the younger gods in the divine war: since Zeus is far mightier than Poseidon, we would expect, in a parallel to the Achaean situation, that the divine faction of Poseidon would also have contended in a desperate fight.

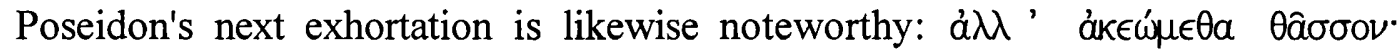

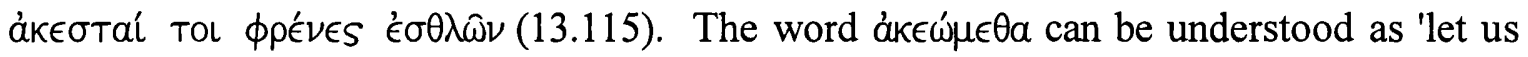

\footnotetext{
${ }^{9}$ Leaf (1902) ad loc. denounces this speech as too long, tautological and ill-suited to its position. I consider that this speech becomes significant when viewed from the perspective of Poseidon's antagonism toward Zeus, and is appropriate to the sub-textual context (the war of the gods).
} 
correct our slackness' ${ }^{10}$ or, by implication, 'let us forget our dissatisfaction with Agamemnon and fight hard for the common cause.'11 'Correction' or 'change' is especially appropriate to Poseidon's character, since he is the deity who challenges the stability of Zeus' sovereignty. So, the latter half of verse 115 - 'the minds of good men can be curable' - could be understood not only as a palliative addressed to the distressed Achaeans, but also to himself. That is, although Poseidon may have been defeated once by his mightier brother Zeus, he neverthless tries to soothe his own mind and to set out for another duel with Zeus.

A comparable reference to Poseidon's vacillation occurs in 15.203 , where he is

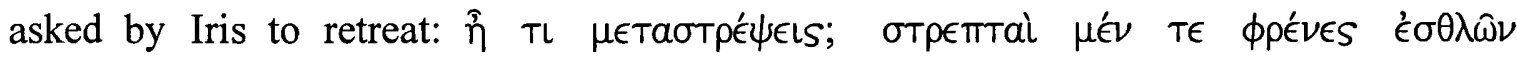
(15.203). This time, his change of mind is negative: he must retreat and yield to Zeus. Poseidon's 'changing mind' is, thus, a notable part of his characterisation in the Iliad, and can be seen as a signifier of his tragic destiny - to be second best among the gods.

Poseidon's next speech to Idomeneus (231-8) is also curious, but can be explained if we view Poseidon as always being relegated to 'second best':

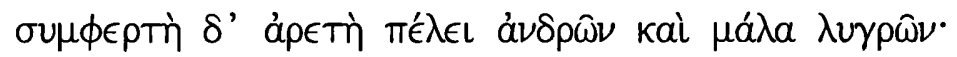

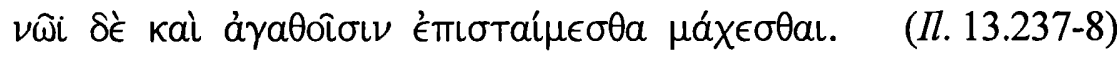

Combination brings courage even in the poorest of fighters, and we two are men who could fight with the best. (Tr. M. Hammond)

\footnotetext{
${ }^{10}$ Janko (1992) ad loc. comments that this verb is used for 'thirst' in 22. 2; 'ship' in 14. 383; and 'error' in Hdt. 1. 167. Leaf (1902) ad loc., following the suggestion of Schol. bT ad loc., suggests that 'the obvious reference of this line is to Achilles'. Leaf's interpretation ignores an essential logic: Poseidon encourages the Achaeans to fight bravely even if Achilles is absent.

${ }^{11}$ Willcock (1984) ad loc.
} 
Poseidon says that 'even if we are poor fighters, together we too can fight the brave.' This might be a pre-fabricated maxim, ${ }^{12}$ but it is significant that it is ascribed to Poseidon. Certainly it is appropriate to Thoas, whose guise Poseidon has assumed, but it is also appropriate to Poseidon himself, who must rely on an alliance with the other gods in order to overcome Zeus.

The speech of Idomeneus concludes the discourse between Poseidon and the Achaeans, and occurs just before the 'rope of war' image. It is significant that Idomeneus compares Ajax with Achilles:

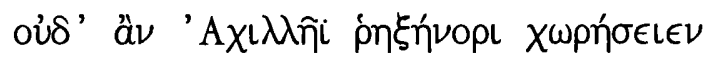

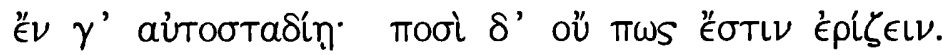

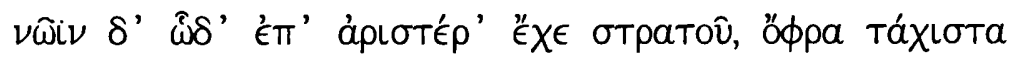

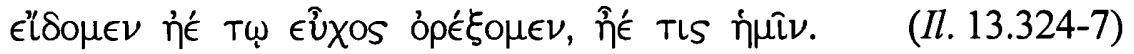

He [Ajax] would not even give way to Achilleus, breaker of men, in a standing fight - but at the run there is no competing with Achilleus. So keep on as we are for the left of the army, so we can know soon whether we shall give his triumph to another man, or he to us. (Tr. M. Hammond)

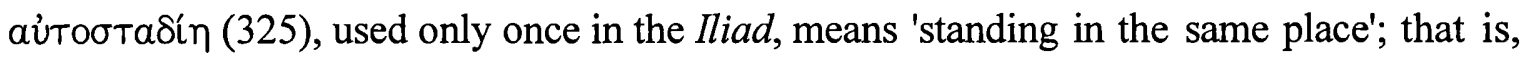
in close combat. ${ }^{13}$ When the Achaeans are reluctant to respond to Hector's challenges in book 7, it is Ajax who is recognised as the second best of the Achaeans (after Achilles) when he fights with Hector (7.181-90). Given that the chief point of Idomeneus' speech

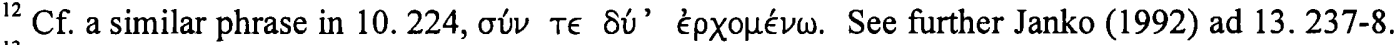

${ }^{13}$ Willcock (1984) ad loc. explains the two Homeric methods of fighting: close combat, in which the necessary qualities were physical strength, mental endurance and good weapon skill; and, more open fighting, with some fleeing and others pursuing, in which foot-speed was the foremost requirement.
} 
is the anticipation of Ajax's victory, it is pertinent to note the mention of Ajax's disadvantage in open fighting. Ajax - second best - is appropriately analogous to Poseidon: although Ajax is not mightier than Achilles, there is at least some hope of victory in close combat. Consequently, this passage could be interpreted as underscoring the 'rope-of-war' "metaphor" which we take to represent a duel of sorts between Zeus and Poseidon. It is apt that, immediately after Idomeneus' speech, Poseidon attempts a

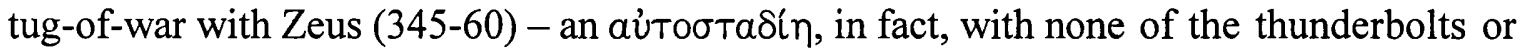
lightning which typify divine open air combat.

The opening of the 'rope-of-war' passage focuses attention back on the two gods:

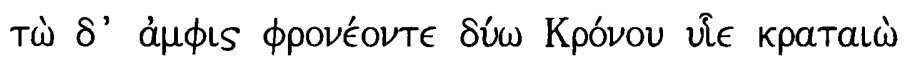

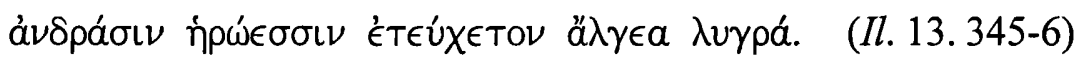

And the two powerful sons of Kronos, their purposes opposed, caused grim suffering for the human warriors. (Tr. M. Hammond)

The tension operates on two levels: on the surface, the passage alludes to the human battle and the sides to which the two gods lend their support; the sub-text, however, is the serious conflict between Zeus and Poseidon, as the sentence construction clearly

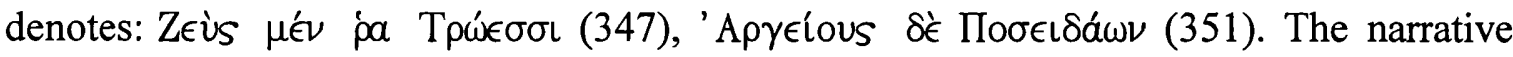
then offers an intensely focused account of Poseidon's subordination:

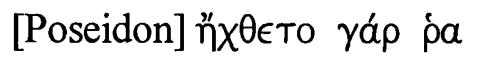

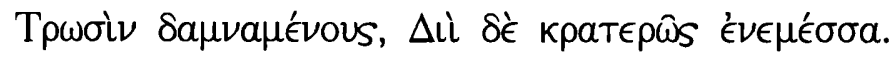

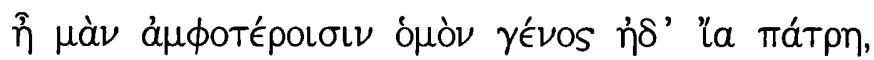

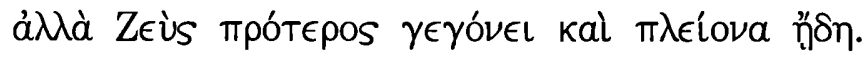

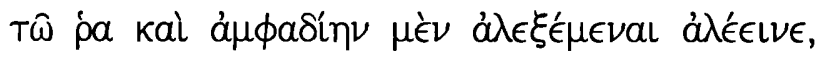




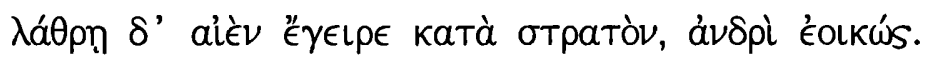

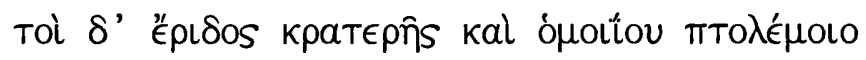

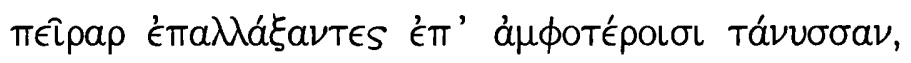

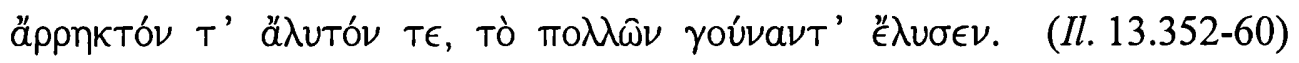

...he [Poseidon] felt pain to see them broken by the Trojans, and furious anger at Zeus. Both these were indeed of the same descent and parentage, but Zeus was the older born and had wider knowledge. So Poseidon avoided giving open help, but went covertly up and down the army in man's shape, constantly rousing them to fight. So those gods crossed and tied the ropes of hard conflict and levelling war over both armies, and stretched them taut, not to be slipped or broken - but they broke the strength of many men. (Tr. M. Hammond)

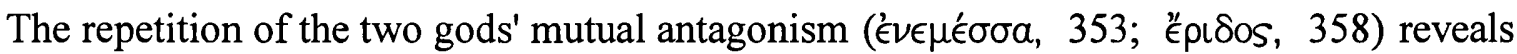
that there is more at stake here than merely a playful allusion to the humans' war; rather, the passage raises the spectre of cosmic war. Consequently, we should consider that the poet is drawing the motif from an older epic of the battle between the gods. Just as Ajax is subordinate to Achilles, so is Poseidon to Zeus (355): Poseidon is younger in age and inferior in knowledge. The scholiast condemns Poseidon's tactics as lacking in dignity (Schol. bT) - but what alternative does he have if he is to persist in challenging the mightier Zeus?

As the Iliad narrates it, the result of the human battle depends on the outcome of this combat between the two gods. While we cannot know for certain the outcome of the $U r$-battle between the gods, we can postulate that their combat might have settled the cosmic war. In terms of military strategy, the duel would occur early in the cosmic 
conflict: $^{14}$ a duel being preferable to a clash of entire armies. For instance, when Paris agrees to fight a duel with Menelaos, both armies are delighted (3.111); after this duel is unsuccessful - inconclusive in settling the war - another is suggested, this time between Hector and Ajax (7.67-302). Likewise, in the divine sphere, we might expect that the gods would rejoice at the opportunity for a timely duel between Zeus and Poseidon, thus putting an end to their conflict.

The rope-of-war image in 13.358-60 is appropriate for such a duel. The apparently too grand arming of Poseidon (13.23-8) is best viewed from this perspective, for now this scene becomes neither superfluous nor grandiose, but appropriate to the preparation for a duel of such magnitude and significance. Poseidon, we might suggest, represents, as the mightiest among his followers, his entire faction. In Iliad 13.1-360, I suggest that we can trace an earlier stage in the battle of the gods which begins with the increasing tension between Poseidon and Zeus, and culminates in a duel between the two leaders.

The result of the tug-of-war contest remains ambiguous: it appears to be a tie. However, if we link this episode with the tug-of-war in $8.19-27,{ }^{15}$ Zeus must emerge victorious. In book 8, Zeus boasts that all of the gods and goddesses could not pull him down (8.18-27); this suggests that Poseidon would lose such a confrontation. Zeus'

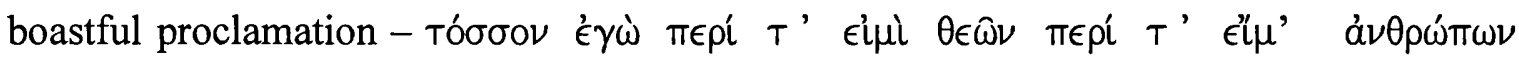

\footnotetext{
${ }^{14}$ Edwards (1991) 31-74 and 67-74 discusses the usual structure of battle. Although he believes that no 'proper' duel occurs in the battle of gods, I propose that this rope-of-war/tug-of-war between Zeus and Poseidon functions as a duel in the first stage of the war between the gods.

${ }^{15}$ The cord / rope receives different descriptions: in the tug-of-war in book 8, the rope is $\sigma \epsilon \iota p \eta$ (8. 19 and

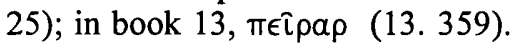


(8.27) - could thus be interpreted as a triumphant declaration of his comprehensive victory over all his opponents.

\section{The wrath of Zeus and Poseidon (Iliad 15. 47-235)}

The disastrous wrath of Achilles is the theme of the Iliad, evinced by the poet's commencement of the epic with the word $\mu \hat{\eta} \nu s^{16}{ }^{16}$ The narrative technique of book 15 correlates Achilles' wrath with that between Zeus and Poseidon. Poseidon's wrath in particular receives sympathetic treatment, and appears most analogous with that of Achilles.

While Poseidon is the focus of book 13, book 15 commences with a description of Zeus' supporters. Following Hera's deception in book 14, Zeus' fury is emphasised in

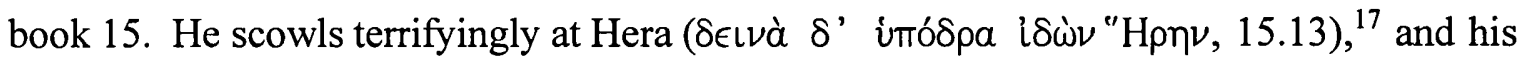

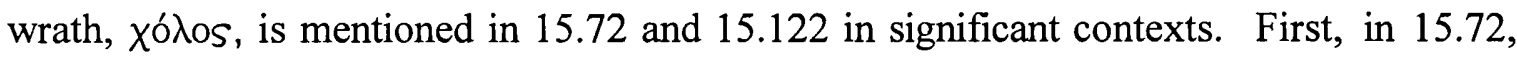
his wrath is associated with that of Achilles; that is, Zeus' wrath will subside when Achilles renounces his own:

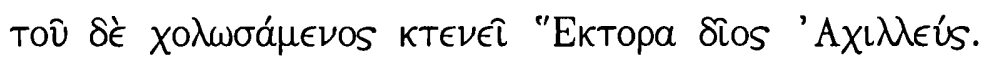

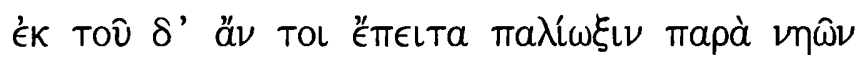

\footnotetext{
${ }^{16}$ In the variants of the proem of the Iliad, Apellicon's version does not mention the wrath of Achilles

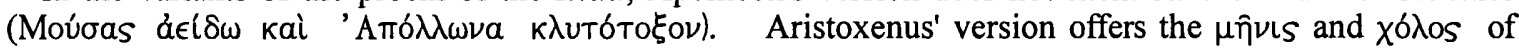
Achilles, but more emphasis is given to Apollo than to Zeus. Cf. Kirk (1985) ad 1.1, who comments that a proem could easily be varied from occasion to occasion to suit the audience or in accord with the length of the version to be presented.

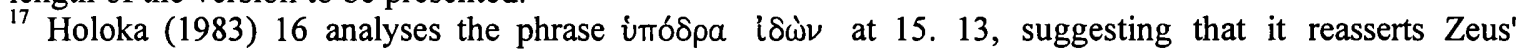
superiority and his entitlement to deference from Hera.
} 


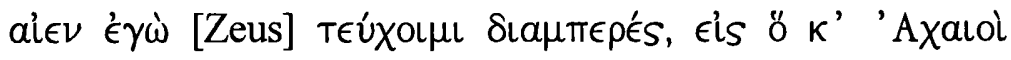

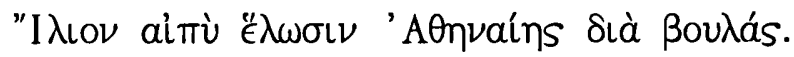

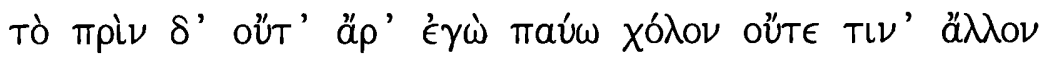

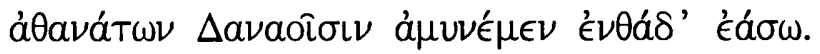

In anger for his friend godlike Achilleus will kill Hektor. And from that time on I [Zeus] shall make a turn in the battle, driving it constantly back from the ships, until the Achaians capture steep Ilios through the designs of Athene. But I shall not cease my anger or allow any other of the immortals to give help here to the Danaans, until the son of Peleus' desire has been fulfilled. (Tr. M. Hammond)

Achilles' wrath against Agamemnon, and then Hector, is paralleled with that of Zeus against Hera, Poseidon and other gods. ${ }^{18}$ The wrath of the two mightiest of the gods and the heroes is amalgamated into one, and functions as the major motivation for the plot.

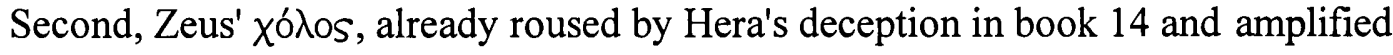
in the tense aftermath, is renewed in 15.122 by Ares' challenge to Zeus' will through his desire to avenge the death of his son Askalaphos (115-8). This time, Athena checks Ares' recklessness:

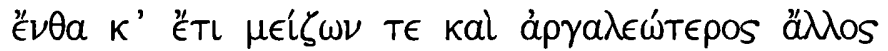

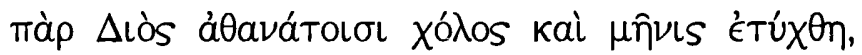

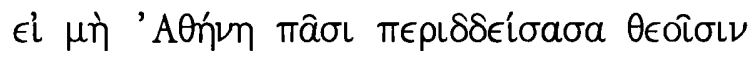

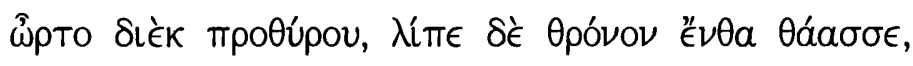

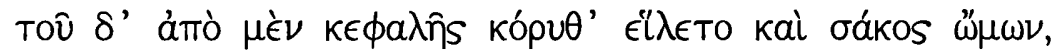

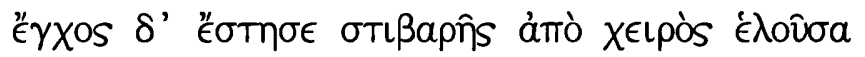

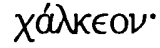
(Il. 15.121-7)

\footnotetext{
${ }^{18}$ Janko (1992) ad 15. 72-3: 'the hero's wrath and the god's are brought back into parallel.' For close discussion of the passages athetised by Aristophanes and Aristarchus (56-77) and Zenodotus (64-77), see Janko (1992) ad 15. 56-77.
} 
And now there would have been caused yet greater and more dangerous anger and fury in Zeus against the immortals, if Athene, in fear for all the gods, had not left the seat where she was sitting and gone out after him through the gate way, and taken the helmet from his head and the shield from his shoulders, and seized the bronze spear out of his massive hand and put it away. (Tr. M. Hammond)

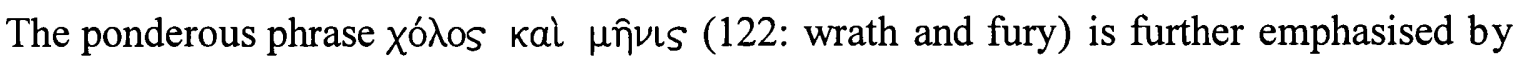
the unreal conditional sentence. ${ }^{19}$ What is also notable is that Zeus' wrath is directed not

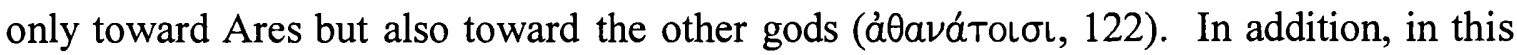
book, this antagonism between Zeus and a divine alliance is heightened by Zeus' position of emphatic aloofness. Zeus is now on top of Mount Ida (15.5), whereas Hera goes back

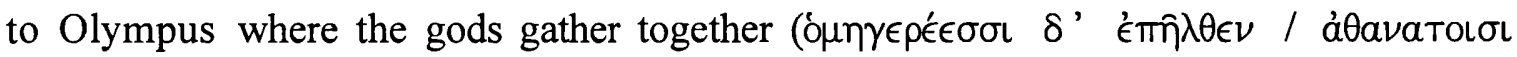
$\theta \epsilon o \hat{\sigma}$ l $\Delta$ iòs $\delta o ́ \mu \omega, 84-5)$. She speaks with the gods, making clear her objectionable mood

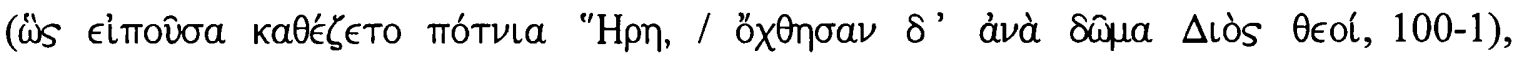

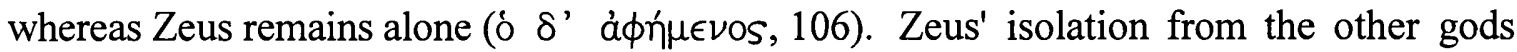
is also implied in the conversation between Hera and Poseidon in book 8.207-11. Hera urges Poseidon to help the Achaeans, wishing that 'Zeus would be annoyed, all alone on

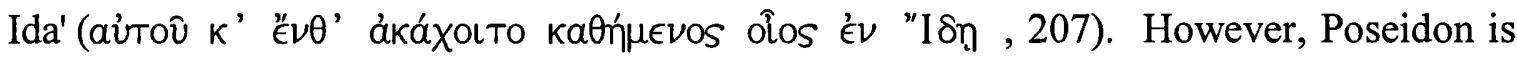
not persuaded:

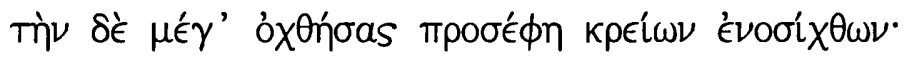

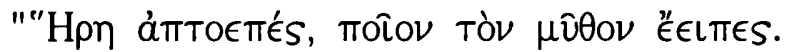

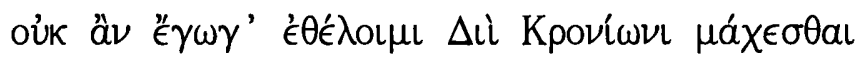

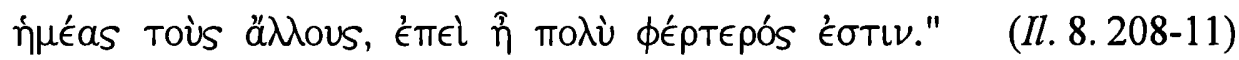

\footnotetext{
${ }^{19}$ Janko (1992) ad loc.: 'the contrafactual conditional emphasises the gravity of the crisis.' He also notes the excitement that is so effectively expressed by hysteron proteron in 124 .
} 
The Earth shaker, powerful lord, answered her in vexation: "Hera, what is this you are saying? This is reckless talk. I would not want the rest of us to fight against Zeus son of Kronos, since his power is far greater than ours."

(Tr. M. Hammond)

Poseidon's answer redirects the focus of Hera's question: although her request is directed to him, he understands it as a problem for all the gods, himself included (inuéas toìs ällovs, 211); perhaps he knows that if he protests against Zeus it will involve the other

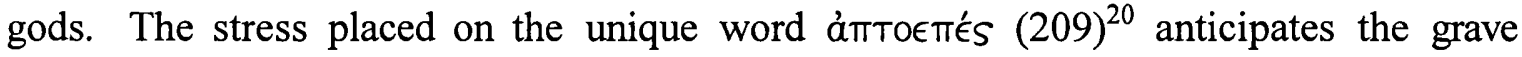
situation that would arise if the gods really went to war against Zeus.

In book 15, the narrative reveals an increased tension between Zeus and the other gods. Zeus asserts that he is pre-eminently the best of the immortal gods in power and strength:

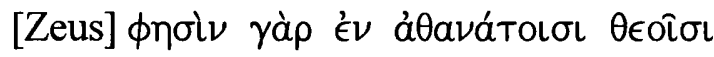

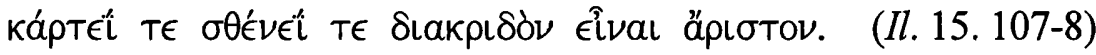

... [Zeus] saying that he is preeminently the best of the immortal gods in power and strength. (Tr. M. Hammond)

Athena predicts that challenging such a powerful figure will bring catastrophe:

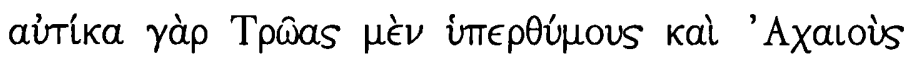

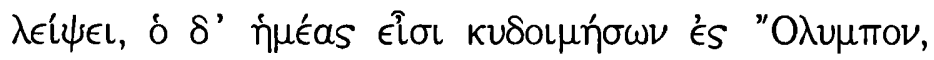

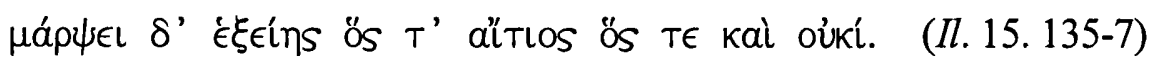

\footnotetext{
${ }^{20}$ Kirk (1990) ad loc. gives the etymology of this word: $* \dot{a}^{-} F \epsilon \pi \tau 0^{-} F \epsilon \pi n / S$, 'speaking a word that should not be spoken'.
} 
Because Zeus will immediately leave the proud Trojans and the Achaians, and come back to Olympos to beat us about, and he will lay hands on each of us in turn, guilty and innocent alike. (Tr. M. Hammond)

Ares and Poseidon are the only gods who venture to protest against Zeus, and once Ares is persuaded to renounce his fight to the death (he acknowledges that he will be destroyed by Zeus' thunderbolt, 117-8), Poseidon remains the final contender to challenge the lordship of Zeus.

A direct clash is ingeniously avoided by Zeus' employment of the messenger Iris. Her function mirrors that of Athena when the latter intervenes in the quarrel between Agamemnon and Achilles (1.194-214). When Iris speaks to Poseidon, she repeats Zeus' words, but adds a further threat of her own devising:

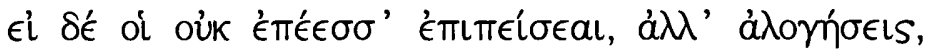

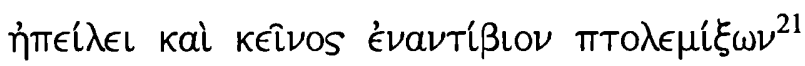

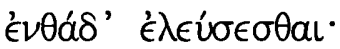

And if you will not obey his orders but intend to ignore them, he threatens to come here himself to fight you face to face. (Tr. M. Hammond)

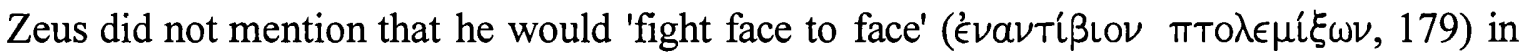
his speech to Iris (158-67). The implication of a duel is extremely effective because, as discussed above, Zeus' superiority in strength has already been emphasised, and Poseidon himself admits that 'Zeus is far mightier than I' (8. 211; 15.195).

\footnotetext{
${ }^{21}$ There are several variants ( $\{\zeta \omega \nu$ Zenodotus; $\{\xi \omega \nu$ Aristarchus). I follow West's new edition (2000) and Janko (1992) ad loc., who comments that the future is more minatory.
} 
Poseidon's appeal for the equal division of the universe $(187-95)^{22}$ is quite logical. Of the two aspects of superiority which Zeus claims - strength and greater age Poseidon only challenges Zeus on the issue of birth; he already admits Zeus' superior power. Consider Zeus' words:

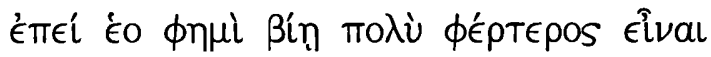

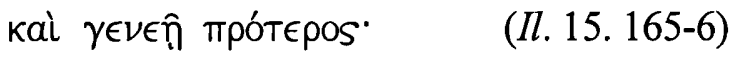
since I say that I am far his superior in strength and his senior by birth. (Tr. M. Hammond)

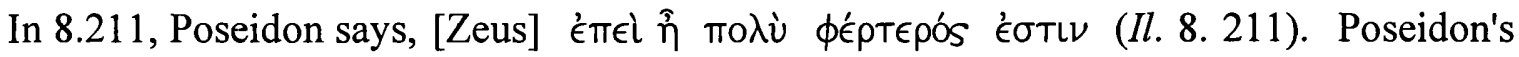
equal portion is assured by his birthright as one of the three children of Cronus. On this basis he attempts to protest against the authority of Zeus' rule.

The division of the universe involved the sharing of $\tau \iota \mu$ ('

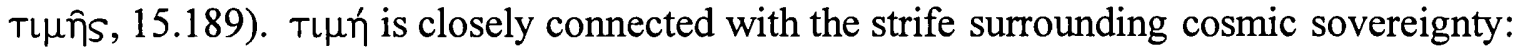

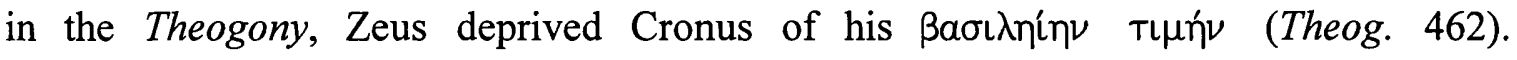
Poseidon's bid for the equal division of portion or honour directly confronts the notion of a hierarchical order. ${ }^{23}$ Since possessions are inseparable from honour, Poseidon could duly demand equal honour with Zeus - and deny the supreme domination of Zeus.

\footnotetext{
${ }^{22}$ Burkert (1992) 90-1 discusses Babylonian influence (Atrahasis 43) on the Iliadic division of the cosmos. The obvious similarities between the Iliad and Atrahasis lie in (1) the division into heaven, sea and underworld (whereas in other old epics, the division is between heaven, earth and underworld, or heaven, sea and earth); and (2) the division is made by drawing lots.

${ }^{23}$ Clay (1989) 12. For the idea of man's will and his lot, see Nilsson (1925) 169-70; Janko (1992) 4-7.
} 
The dangers of this dual system are echoed in the quarrel between Agamemnon and Achilles. In a much-cited passage, Achilles, robbed of a prize and dishonoured by Agamemnon, appeals to Thetis:

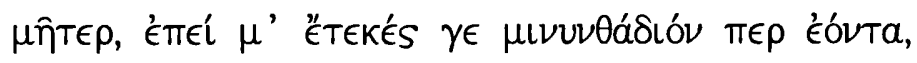

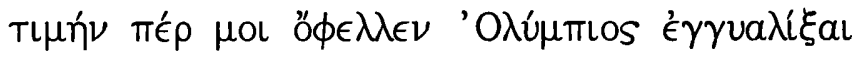

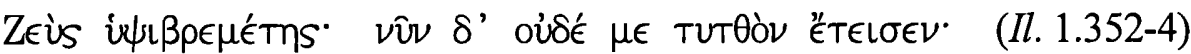

Mother, since it was you that bore me, if only to a life doomed to shortness, surely honour should have been granted to me by Olympian Zeus, the highthunderer. But now he has shown me not even the slightest honour.

(Tr. M. Hammond)

The claim for $\tau \iota \mu \eta$ encapsulated in Achilles' appeal is also thematically central to the poem as a whole. Achilles asserts that honour is due to him on the basis of his birth as a

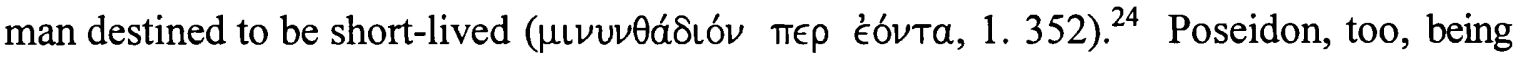

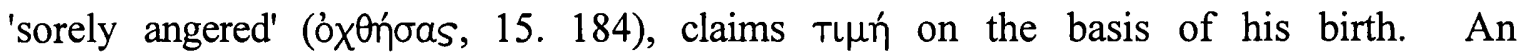
extraordinarily similar logic ('insult $\rightarrow$ wrath $\rightarrow$ claim of $\tau \iota \mu$ ' on the basis of birth') is used in both cases.

Poseidon asserts in 209 that he and Zeus hold equal shares and were granted the

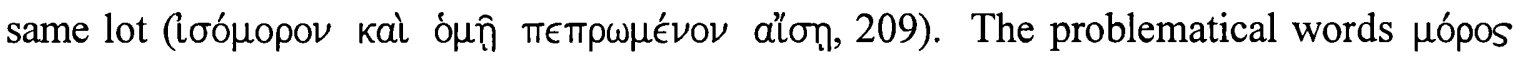
and $\alpha \hat{\imath} \sigma \alpha$ are usually understood in the original sense of 'portion', without any connotation

\footnotetext{
${ }^{24}$ Cf. Chapter I, Section 1.
} 
of death or fate. ${ }^{25}$ Achilles uses the word $\mu$ oipa similarly, meaning portion, and links it

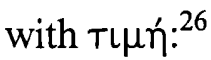

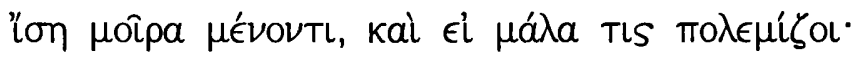

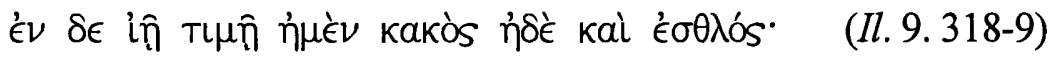

Stay at home or fight your hardest - your share will be the same. Coward and hero are honoured alike. (Tr. M. Hammond)

Achilles complains that men who fight under Agamemnon receive an equal share, regardless of whether they remain in their tents or fight on the field of battle. Poseidon and Achilles express the same idea, but from different perspectives: Poseidon demands an equal portion by reason of his birth, whereas Achilles demands an equal portion in accordance with his work. They each claim a proper portion of honour, and, as the Homeric concept of sharing already inculcates the idea of limit and justice, ${ }^{27}$ they are angry at the unjust treatment they receive from their respective rulers, Agamemnon and Zeus, and, similarly, protest against the legitimacy of their rulers' sovereign rights.

On the basis of these similarities, it is significant that Poseidon levels a reproach at Agamemnon for his behaviour toward Achilles:

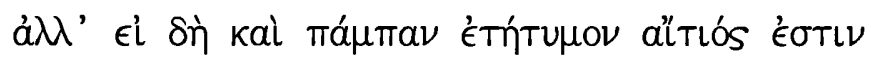

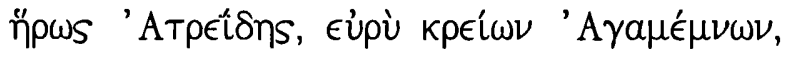

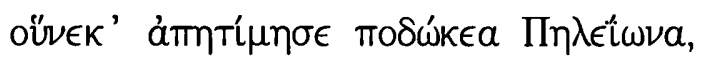

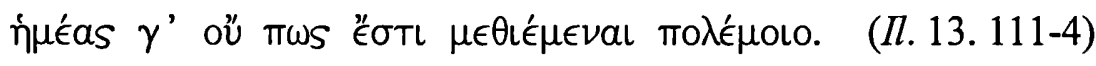

\footnotetext{
${ }^{25}$ Leaf (1902) ad loc.; Janko (1992) ad loc.

${ }^{26}$ Dietrich (1965) 209 suggests that Moira in 9.318 is equivalent to 'honour'.

${ }^{27}$ Dietrich (1965) 208.
} 
But even if all the blame truly belongs to the hero son of Atreus, wide-ruling Agamemnon, for his slighting of the swift-footed son of Peleus, yet we cannot possibly hold back from fighting. (Tr. M. Hammond)

Although Poseidon supports the Achaeans, this reproach is severe: he even speaks of the

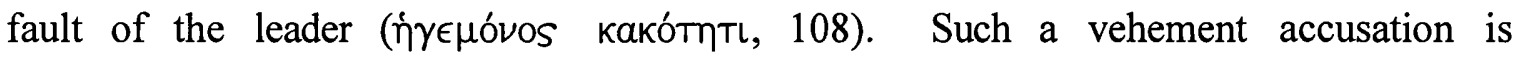
appropriately expressed by Poseidon, because he and Achilles are counterparts in sharing a common wrath against their leaders.

Poseidon and Achilles share another trait: both must yield to the lash. Through Iris' persuasion, Poseidon finally decides to yield to Zeus:

" 'I

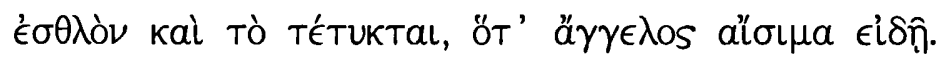

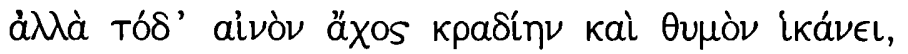

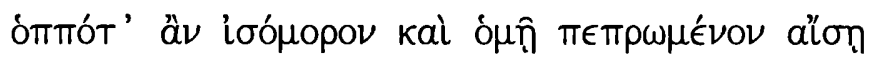

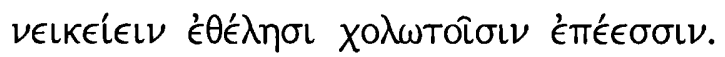

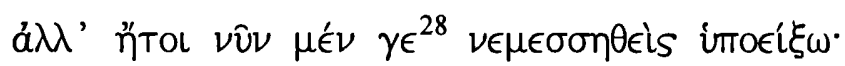

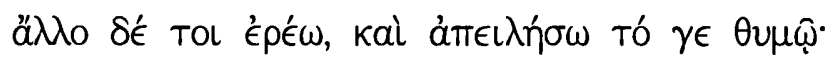

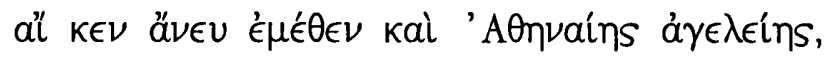

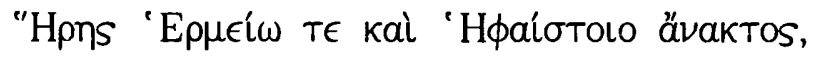

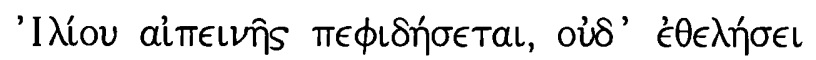

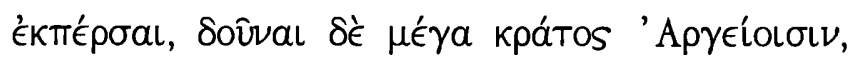

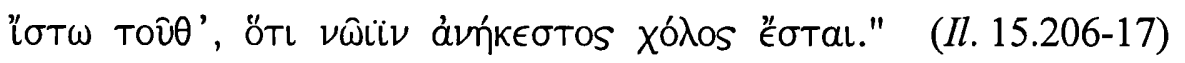

"Divine Iris, what you have said is quite right and true: and it is an excellent thing when a messenger is possessed of good sense. But this is a grievous thing that touches my heart and spirit with pain, when he is ready to abuse with angry words one who has an equal share with him and is destined with the same endowment. Well, for this time I shall hold myself back and give in to him. But I

\footnotetext{
${ }^{28}$ I follow the reading of West (2000): $\gamma \epsilon$ Ar D; $\kappa \epsilon$ vulg.
} 
tell you something else, a threat I make in my heart. If in spite of me and Athene, goddess of spoil, and Hera and Hermes and Lord Hephaistos, Zeus spares steep Ilios, and will not sack it and grant a great victory to the Argives, let him be sure of this, that there will be anger without healing between us. " (Tr. M. Hammond)

Janko notes the similarity between this speech of Poseidon and that of Achilles in 16. 49$63:{ }^{29}$ that is, (1) acknowledgement of what was said (15. 206-7 / 16. 49-51); (2) restating the grievance (15. 208-10/16. 52-9); and (3) yielding with a threat (15. 211-7/ 16. 60-3). Although the sorrow of Poseidon overshadows that of Achilles, the two speeches are similar in diction. Verses 15. 208 and 16. 52 are exactly the same, and the following verses (15. 209 and 16. 53) express similar wrath against the ruler. Both Poseidon and Achilles share 'bitter sorrow' (aìòv äxos, 15. 208 and 16. 52), ${ }^{30}$ and both think that

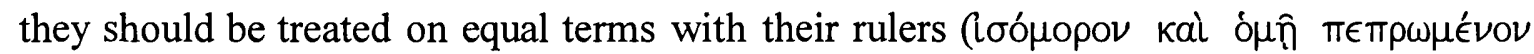

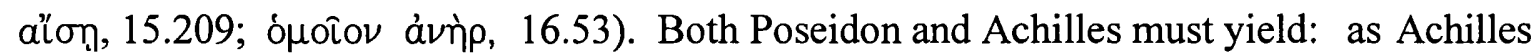
recognises Agamemnon's greater power (16.54), so, too, must Poseidon admit Zeus' power and seniority in age $(15.165-6) .{ }^{31}$

If Poseidon had not yielded, a great war might have erupted; note Zeus' words:

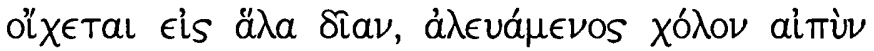

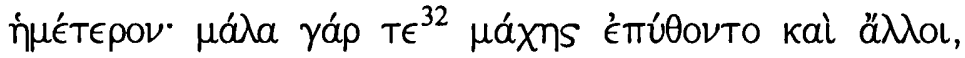

\footnotetext{
${ }^{29}$ Janko (1992) ad 15. 206-8 and ad 16. 49-63, following Lohmann (1970) 274, comments that Achilles' speech to Aias (9.644-55) follows the same pattern.

${ }_{30}$ Aphrodite also feels aivòv äxos (Hy. Aphr. 198-9). It is worth noting that both Poseidon and Aphrodite surrender to Zeus' power, and both express the same emotion. See Chapter VI, Section 1.

${ }^{31}$ Zeus is the eldest in the Iliad, but the youngest in the Theogony (478). This shows the different usage of motifs between the two poems: for the poet of the Iliad, Zeus' seniority is an indispensable justification for Poseidon's surrender to him; for Hesiod, Zeus must be the youngest to fit with the Hesiodic logic of succession in which the youngest son overthrows his father.

${ }_{32}$ Allen (1902) and West (2000) read $\kappa \epsilon$, meaning 'would have heard'. I follow Janko (1992) ad loc., with Sch. D and most early codices, in reading $\tau \epsilon$, 'have experienced'.
} 


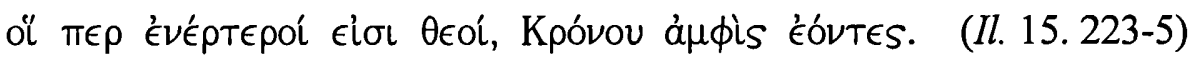

[Poseidon] has left now and gone into the holy sea, to avoid the stark fury I would have shown - for even the gods below with Kronos have experienced battle (with me). (Tr. M. Hammond, adapted)

Zeus knows that a divine conflict would involve all the gods, even the Titans ('lower gods'), and that his lordship is secured by undermining Poseidon. The moment when Poseidon decides to retreat, therefore, is pivotal to Zeus' sovereignty. The critical significance of this moment is akin to that in which Athena caught Achilles by his yellow hair (1. 197): Achilles then goes to his own huts (1.306) and retreats from the war. Similarly, we see that, after his withdrawal from the burgeoning conflict, Poseidon also retreats physically, going down into the sea (Il. 15.223).

Poseidon's final threat as he yields (Il. 15.211-7) is a reflection of his self-respect or pride and desire for honour. Iliadic heroes are also motivated to risk their lives to defend their pride. For instance, Sarpedon, facing his inevitable death, says, 'if we were to live forever, ageless and immortal, I would not be fighting in the front ranks' (Il. 12.322-4). Unlike Sarpedon, Poseidon is immortal, but his pride remains of great significance, and he cannot tolerate humiliation. As Nilsson notes, the anthropomorphism of the Iliadic gods shows their human traits; and gods, too, must be measured by the same moral standards as mankind. ${ }^{33}$ Just as the heroes in the Iliad are not morally unfettered princes or

\footnotetext{
${ }^{33}$ Nilsson (1925) 159.
} 
supermen, so too the gods, especially Poseidon, are constrained; Poseidon's life is not easy: he yields and suffers. ${ }^{34}$

Gods are said to be 'blessed' and to 'live at ease'. Achilles tells Priam that humans live in misery but 'gods are free from care' (Il. 24. 525). Indeed, the delightful circumstances of the gods are often emphasised. ${ }^{35}$ However, Homeric gods are not uncomplicated; they are not infallible, and even the heroes recognise that there are limits on divine power. For example, Nature goes her own way (Il. 6. 146-8), and the gods cannot protect their favourites against death. ${ }^{36}$ As Odysseus says, even Poseidon cannot restore the Cyclops' eye (Od. 9. 525).

One's portion is one's due and regular share, and the final inevitable portion for humans is death. If death for humans signifies the change from the brightness of life to the dark and meaningless existence of death, ${ }^{37}$ exactly the same picture is offered to those gods hurled into Tartaros. According to Détienne and Vernant, ${ }^{38}$ to strike a god with Zeus' thunderbolt is to deprive him of the vital force that previously animated him, and to relegate him, forever paralysed, to the limits of the world, far from the dwelling of the gods where he formerly exercised power. The thunderbolt is the ultimate source of Zeus' authority, as we see from the fates of the Titans and Typhoeus - defeated, banished to a meaningless existence, never to emerge. Even gods abhor the dark place beneath (20.65).

\footnotetext{
${ }^{34}$ I agree with Nilsson (1925) 177, who writes that the legacy bequeathed by Homer to tragedy is the humanisation of the gods and the increasing relevance of myth to men.

${ }^{35}$ For example, Griffin (1980) 167, 189.

${ }^{36}$ Zeus cannot alter the aløa of Sarpedon (16. 441), nor can Hera change the aîa of Achilles (20. 1278). The day of one's death is determined at the day of birth (Il. 23. 79), regardless of the gods' will. For the metaphor of 'spinning the destiny', see Dietrich (1965) 290.

${ }^{37}$ Griffin (1980) 143.

${ }^{38}$ Détienne and Vernant (1978) 75.
} 
By definition, there is no death for gods. However, Zeus' threat of a duel with Poseidon (15. 179) implies that, in defeat, Poseidon too would suffer the fate of descending into this dark and meaningless existence. Before he yields, Poseidon faces a crisis equal to that of human death. When he yields, however, he still clings to the shreds of his pride and self-respect.

We have noted that the characterisation of Poseidon is remarkably analogous to that of Achilles. In the light of my suggestion that the poet of the Iliad drew inspiration from an earlier story of the battle of the gods, we might propose that his focus on Achilles' heroic wrath and striving for honour derives from this stratum of material, or, at the very least, was a deliberately developed doublet to make the wrath of Achilles run parallel to that of Poseidon. The poem is built around attitudes which reflect fundamental questions of heroic wrath, heroic shame, and the acceptance of death. ${ }^{39}$ Both human characters and Poseidon are delineated through their responses to these questions. As the fate of Achilles is tragic, so, in a sense, is that of Poseidon. By using the motif of Poseidon's wrath as the basis for his poem, the poet makes the dispute surrounding Achilles' wrath clearer and more profound. Thus the motifs of wrath -- of Zeus and Achilles, Poseidon and Achilles -- work together to develop a more coherent artistic product.

3. The Reordering of the Universe (Iliad 20. 54-74; 21. 385-520) 
In the opening scene of book 20 , the gods make preparations for the fight, suggesting a conflict on a cosmic scale (20.54-74). The combat pairing of the gods is listed (20.6774 ) and the actual fighting is described (21. 385-520). Overall, the gods are divided into two camps, and those who favour the Greeks stand on the Greek side with Poseidon. This sub-plot is so well integrated that it seems a natural consequence for the gods to join the human war. But why, as Apollo complains at 21.462-3, do the gods fight with each other on behalf of the humans? I suggest that reading an earlier cosmic battle underlying this text makes possible a fuller appreciation of the poet's subtle intertextualities. On such an interpretation, in some pre-Iliadic stories, the gods could have been antagonistic to each other; and in this text they may retain their original spirit of partisanship, which operates aside from the human battle. ${ }^{40}$ That is, the human battle does not motivate the gods to fight in partisan formation; rather, they fight in the human battle because of their original, partisan nature. This might explain their apparent preoccupation at fighting and shouting at each other (21.385-6).

Some scholars criticise the imbalance of the two accounts of the Theomachy: the solemn proclamation (20.54-74), then the 'anticlimax' of this major divine battle (21. 385520 ) in which some gods are reluctant to fight. ${ }^{41}$ I will focus on the passages concerning

\footnotetext{
${ }^{39}$ Griffin (1980) 80.

${ }^{40}$ I agree with Nilsson (1925) 155, who suggests that the spirit of partisanship affects all the gods, and that they pursue their ends by every means, including cunning and deceit.

${ }^{41}$ Leaf (1902) 382 comments that the Theomachy passage in book 21 is 'the anticlimax' and 'poetically bad'. Edwards (1991) ad 20. 67-74 suspects that the passage [20. 67-74] was 'added to the monumental poem at a later date', on the grounds of structure (there is no parallel to the listing of combatants in

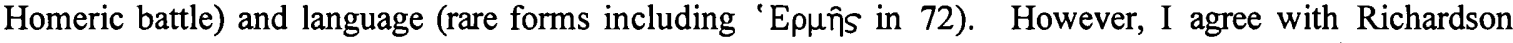
(1993) ad 21. 383-513, who suggests that the account in 20. 54-74 provides a frame for the battle in 21. 383-513.
} 
Poseidon and Zeus to determine the interrelation of these two apparently imbalanced accounts, and to consider why some change of mood occurs.

When Zeus calls the gods to assembly at the beginning of book $20(1-12)$, talk is sustained only between Poseidon and Zeus (13-30). Poseidon sits in the middle of the

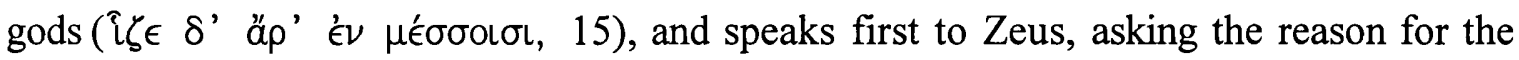
assembly (16-8). This should remind us of how Achilles opens the debate in book 1. 5967. Zeus answers, 'you know, Earth-shaker, the decision in my mind' (20). The tension between the two is overt and double-edged, for this discourse seems to function as a declaration of war.

In terms of the structure of battle, we have already recognised the preliminary stage, namely the duel between the mightiest of the two sides - as we interpreted the rope-of-war incident between Zeus and Poseidon (13.358-60). Now, we see the meeting of the leaders of both sides, and anticipate that the war will soon be fought. The description of the shaking, from above and below, of the valleys and mountains (20. 5474) sets the scene for a huge conflict, and is highly appropriate to a war on the cosmic scale. At this stage, Zeus is present:

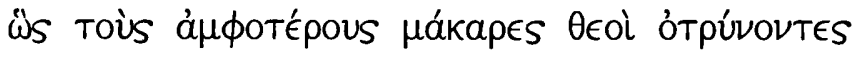

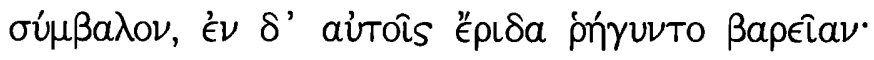

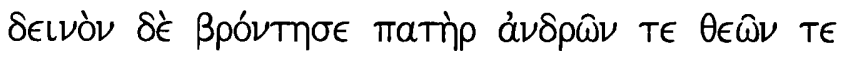

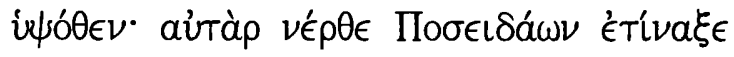

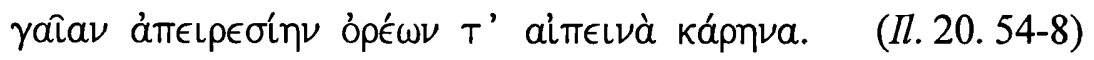

So the blessed gods drove on both sides and brought them to the clash: and they broke out bitter conflict among themselves. The father of men and gods thundered 
fearfully from on high, and beneath them Poseidon shook the limitless earth and the high peaks of the mountains. (Tr. M. Hammond)

The tension which was foreshadowed in book 13. 1-16 is now reaching its climax. As is proper procedure, the leaders of both sides are honoured with introductions. It appears that a fierce clash will now begin. However, Zeus does not participate in the war; this is mentioned twice, both in book 20 and book 21 :

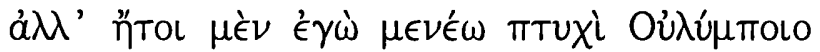

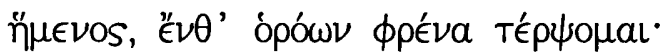

But now I shall stay here, sitting in a fold of Olympos where I can look on and delight my heart (Tr. M. Hammond)

ăi $\delta$ dé Zeìs

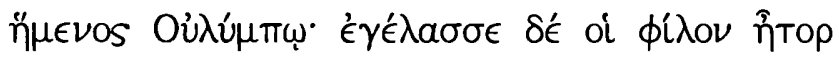

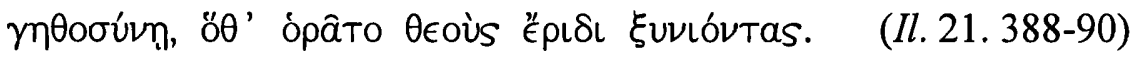

Zeus heard it where he sat on Olympos: and his heart within him laughed for joy, when he saw the gods joining in conflict. (Tr. M. Hammond)

These passages - Zeus' prediction and Zeus' action - make it clear that the Theomachy is put on for Zeus' amusement. Perhaps the earlier myth of the battle of the gods to some extent conditions the way the story is told here. What we are now given is essentially mock fighting, and Zeus is a superior bystander and (no longer) a participant. This change of direction away from the anticipated, serious theomachy is a sharp deviation by the poet which completes -- and demonstrates the completion of -- the reordering of the universe by Zeus. 
The laughter of Zeus (21. 389) can be compared with that of Agamemnon (Od. 8.78), who rejoices at a quarrel between Odysseus and Achilles. ${ }^{42}$ But I would also suggest that Zeus' laughter here is analogous to that in the Hymn to Hermes (389) which decisively - and mysteriously - settles the dispute between Apollo and Hermes. ${ }^{43}$ In the Theomachy, Zeus is not the leader of a combatant side, but the judge who respects the claims of all parties.

As the result of this change, his attitude to the battle of the gods becomes similar to his attitude to the human battle. In contrast to book 13 , Zeus now watches the battles of gods as well as humans. Like Achilles at the funeral games for Patroclos (Il. 23.262897), Zeus is superintendent and no longer a participant. Although he stirs up the battle

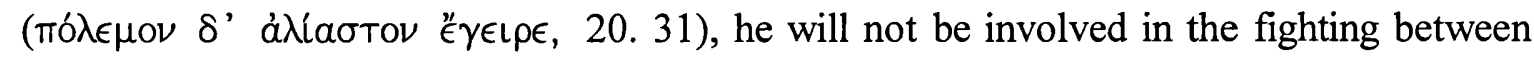
the gods. This might cause cosmic disorder, but his supremacy will remain secure.

We see that Poseidon is especially respected among the gods; for example, Apollo refuses to fight with Poseidon (21. 472-3). Artemis' accusation about Apollo's refusal (21. 474-7) implies that there had been antagonism between Poseidon and Apollo even before this incident: ${ }^{44}$

\footnotetext{
${ }^{42}$ Schol. BE ad Od. 8.77 comments that the quarrel is about the tactics to be used in sacking Troy: Achilles demands brave fighting $(\alpha \nu \delta \rho \in(\alpha)$, and Odysseus supports contrivance ( $\mu \eta \chi \alpha \nu \eta \hat{)})$. See Griffin (1980) 183-4, who writes that Zeus is like one who enjoys the spectacle of others struggling and being humiliated for his own pleasure.

${ }^{43}$ When Apollo accuses Hermes of the theft of his cattle, it is Zeus' laughter, not the scales of justice, which resolves the quarrel (Hy. Herm. 324).

${ }^{44}$ Aristarchus athetised 475-7 as being inconsistent with the character of Apollo at 468-9. Willcock (1977) 49-50 regards this passage as 'ad hoc invention', asserting that, 'nothing at all makes it probable that Apollo should have made a practice of boasting in this way.' However, in view of the partisanship of the gods, it is highly probable that Apollo might have spoken thus.
} 


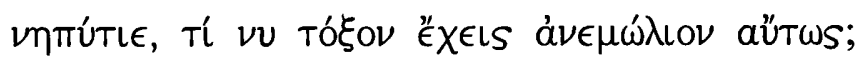

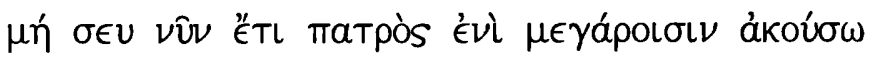

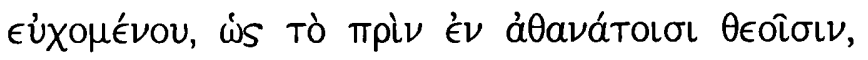

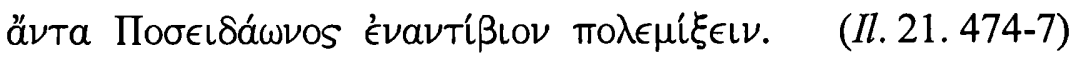

You poor fool, why then do you carry a bow which is nothing more than wind? May I never now hear you boasting in our father's house among the immortal gods, as you have before, that you could fight face to face with Poseidon.

(Tr. M. Hammond)

Artemis' specific mention of previous occasions when Apollo declared his boastful decision to defeat Poseidon is significant: these occurred in their father's megaron, among the immortal gods (475-6). That is, Apollo made his boastful claim in front of Zeus, in assemblies of the gods. Were these assemblies similar to the one to which Zeus called the gods in 20. 4-5 (that is, preceding the outbreak of war)? On such an occasion the young Apollo might have uttered, perhaps with Zeus' favour, ${ }^{45}$ such an appropriately threatening proclamation against the leader of the 'enemy'.

Hera's response to Artemis' reproach calls for attention. Hera perceives Artemis' condemnation as hostile toward herself:

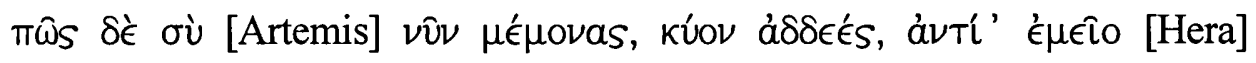
$\sigma T \hat{\sigma} \sigma \in \sigma \theta a l ; \quad$ (Il. 21.481-2)

And how do you now dare, you shameless bitch, to stand against me? (Tr. M. Hammond)

\footnotetext{
${ }^{45}$ For the good terms existing between Zeus and Apollo, see Chapter V on the Hymn to Apollo, esp. Section 4. In the Iliad, too, Zeus and Apollo collaborate several times: for example, in 15. 220-62, Apollo is sent by Zeus to rouse Hector's strength (232); and Hector is revived by Zeus' will (242); in 17. 582-96, Apollo encourages Hector (582), and Zeus shakes the aegis to threaten the Achaeans (593-6). Significantly, Apollo shares the aegis with Zeus (15. 229-30, 318-22; 24. 20).
} 
For Hera, an insult to Poseidon is an insult to herself; the alliance between Hera and Poseidon is thus consistent throughout the epic.

The story of Apollo's ceding victory to Poseidon without a fight finds a parallel in the episode of the spear-throwing contest in which Achilles awards Agamemnon the prize without a contest (23.884-97). The nobility of Achilles is particularly marked in the funeral games in book 23 , because it differs so greatly from his cruel treatment of Hector's body in the preceding account. Achilles' behaviour is now perfectly under control in the games, and he renders fair judgement to all. His decision with regard to Agamemnon admitting that Agamemnon is 'supreme in power' (891) - marks their final reconciliation. Likewise, Poseidon's victory without a battle implies a peaceful close to the battle of the gods.

Just as Achilles watches and presides over the funeral games, so too does Zeus preside at the battle of the gods. The centripetal progress of Zeus in this scene is conspicuous in several ways. First, it is out of respect for Zeus that Apollo and Hermes refuse to fight: Apollo avoids the fight with his uncle out of respect (21. 468); Hermes says it is dangerous to fight with the wives of Zeus (498-9). Second, all of the gods gather round Zeus after their fight: Artemis comes to Olympus and sits in tears on Zeus' lap (505-6), and the other gods also take their seats beside him (520). ${ }^{46}$

\footnotetext{
${ }^{46}$ Hades goes back to Zeus' house after his fight with Heracles (5. 398); Ares sits beside Zeus after he is hurt by Diomedes (5. 869).
} 
Verses 518-20 function as the closing section of the Theomachy, symbolising that all disputes and conflicts are settled, and Zeus has achieved his supremacy over the Olympian cosmos:

oi $\delta$ ' äh

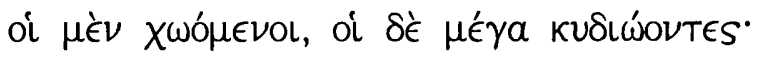

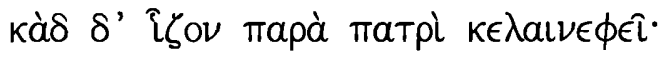

But the rest of the ever-living gods went back to Olympos, some angry and others exulting, and they took their seats beside the Father, the lord of the dark clouds. (Tr. M. Hammond)

Even those who are angry (oi $\mu \grave{\epsilon}$ $\chi \omega o ́ \mu \epsilon \nu o l, 519)$ come to sit beside Zeus. A problematic aspect of the Olympians' interrelationship has been settled and they seem to become systematised into an ordered divine community. The prominent deities are described, emphatically, as 'brother of Zeus' (Poseidon, 468) or 'the wife of Zeus' (Hera, 499). ${ }^{47}$ This is a quite different picture from the stories of Uranus and Cronus, where the father seems to be 'a stranger who is nothing to do with the mother and the children'. ${ }^{48}$ In Zeus' cosmos, the family now enjoy a relationship with him. The existence of challengers implied disorder, but with their defeat the Olympian regime has been set on a new footing.

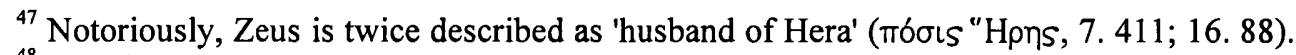

${ }^{48}$ Otto (1955) 31; see also Caldwell (1989) 161. Cf. Chapter IV, Section 2.
} 
The plan of Zeus is, at the last, a mystery. ${ }^{49}$ We do not know exactly how Zeus finally subdued Poseidon and his alliance. But, in the poet's hands, under the plan of Zeus, not only humans but also gods suffer or rejoice. As Poseidon says (Od. 1. 338), both gods and men accomplish mighty deeds that will become epic song. Griffin's words about the humans - 'from suffering comes song, and song gives pleasure ${ }^{150}-$ are applicable even to the gods. The function of the Homeric gods is sometimes relegated to that of mere background to human deeds, but the stories of the gods have their own internal logic and consistency.

It is generally admitted that, even if Homer created an original poem, he drew upon a rich earlier epic tradition. I believe that the poet of the Iliad composed his poem by exploiting and repeatedly referring to an earlier epic of the battle of the gods, probably the Gigantomachia. The consistency in the portrayal of the characters of the Iliadic gods reflects the aristeia of the gods of the distant past. When Achilles says 'even the mighty Heracles could not escape death' (18.17), it might echo the suffering of Poseidon, as 'even Poseidon could not escape suffering'.

\footnotetext{
${ }^{49}$ Griffin (1980) 169-70 remarks that the complex plan of Zeus, which involves helping Troy but not actually routing the Achaeans, leads to ambiguity.

${ }^{\text {so }}$ Griffin (1980) 102.
} 


\section{Chapter IV : The Birth of Athena}

Hesiod's Theogony celebrates, thematically and structurally, the supremacy of Zeus. Hesiod's grand theme is Zeus' sovereignty and its meaning: in spite of the various challenges to his power, Zeus obtains both supremacy and the means to secure it. Although some scholars claim that it did not occur to Hesiod to question why Zeus' sovereignty would survive, ${ }^{1}$ I assume that one of the main purposes of the Theogony is to clarify the reasons for Zeus' success and ultimate victory. My interpretation is that the stories of Uranus and Cronus' generational strife are intended as lessons for Zeus aids to his own survival - which influence Zeus' ingenious way of eliminating this perpetual cycle of internecine conflict by giving birth to Athena. To demonstrate this, I will start with Near Eastern influences on Hesiod's succession myth. ${ }^{2}$

\section{Near Eastern succession myth and Hesiod's Theogony}

Archaeological evidence demonstrates that the representation of the thunderbolt, usually conceived as a typically Greek image of Zeus, is clearly dependent on an eastern model. ${ }^{3}$ In the realm of epic, too, oriental myths undoubtedly provided Hesiod with raw material

\footnotetext{
${ }^{1}$ Solmsen (1949) 164.

${ }^{2}$ It is widely accepted that there are clear similarities between Near Eastern and Greek theologies. See Walcot (1966) 1-54; Caldwell (1989) 80-1; Burkert (1992) passim; Graf (1993) 92-3; West (1997) 279-83.

${ }^{3}$ Burkert (1992) 16-9 is persuasive in his discussion of 'orientalising works'; in particular, the bronze shields from the Idaean cave on Crete, some of which have an overtly Assyrian appearance.
} 
which he arranged in new patterns. It is widely accepted that the succession of Greek heavenly rulers, Uranus, Cronus and Zeus, has an obvious parallel in Hurrian myth. ${ }^{4}$ Alalu, the first king, is defeated by Anu (the Sky-god), and goes down to the dark earth. Anu takes the throne, but nine years later is castrated by Kumarbi, who swallows Anu's sexual organs. Kumarbi is impregnated and spits out three 'dreadful' gods: the Storm-god, the river Aranzahas, and Tasmisus. Anu advises the Storm-god, while he is still inside Kumarbi, of the places from which the Storm-god may emerge from Kumarbi; he also plots to destroy Kumarbi with the help of the Storm-god. The Storm-god defeats Kumarbi and takes over the kingship in heaven. The succession is as follows:

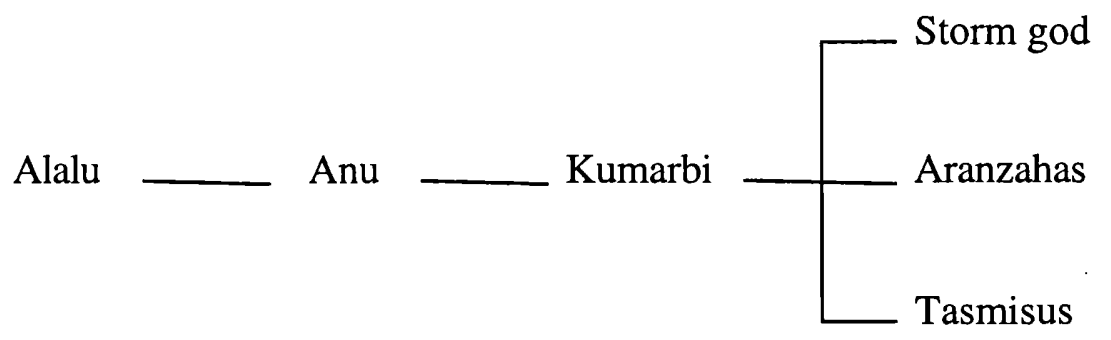

Burkert posits the correspondence of the Storm-god to Zeus. ${ }^{5}$ Certainly, several features of their succession myths are analogous: first, the motif of swallowing; second, Kumarbi (identifiable with Cronus) castrates the previous ruler Anu (identifiable with Uranus); third, the Storm-god (= Zeus) is one of three brothers; and, fourth, Anu helps the Stormgod against Kumarbi by giving advice even before the Storm-god is born - just as Uranus

\footnotetext{
${ }^{4}$ The Hurrians were active from shortly after 2500 B.C. until the early centuries of the first millennium B.C. The kinship in Heaven text is Hurrian, either translated straight into Hittite or freely adapted. Some of the divine names, such as Kumarbi, are Hurrian, while Alalu and Anu are Babylonian gods. See further Walcot (1966) 19-20. I use the translation of A. Goetze: ANET (1969) 120-1.

${ }^{5}$ Burkert (1992) 94 also offers an interesting discussion on the collective idea of 'gods': in Hurrian myth, the Storm-god banishes Kumarbi and other 'ancient gods', which corresponds to Zeus' defeat of Cronus and the Titans as a collective. West (1997) 280 lists the similarities between the Hesiodic Theogony and the
} 
(with Gaia) ensures Zeus' survival by giving advice to Rhea before Zeus' birth (Theog. 474-6).

There are also differences, not only in details but also in the main structure of the plot. ${ }^{6}$ The most conspicuous is that Zeus (the third god) halts the cycle of sovereign strife; in the Hurrian myth the Storm-god (the fourth god) does not seek to stop the cycle of strife, nor to rule over Heaven eternally. The Hurrian myth seems to emphasise continuous change of sovereignty; in contrast, the significant element of the Theogony is Zeus' final victory. Clearly Hesiod puts great emphasis on the cessation of generational strife that resulted from Zeus' triumph.

The myths also differ in that, in the Hurrian myth, succession to sovereignty is effected by violence in battle - not as a consequence of a blood relationship between father-son. These battles are repeated between Alalu and Anu, Anu and Kumarbi, and Kumarbi and the Storm-god, and in each case we see that the previous ruler is overcome by the physical strength of his successor. The simplest principle works here: the strongest wins and rules the universe. In Hesiod's Theogony, physical strength is less of a motivating force in succession than is generational strife, in the sense that a female figure, either a wife or a mother, always interferes in the process of succession. Although the physical strength of Zeus is often mentioned in the Theogony, ${ }^{7}$ in fact it is Gaia who is the dominant figure in plotting the succession and who plays the decisive, i.e. motivating,

\footnotetext{
Song of Kumarbi, including that the deity named KA.ZAL issues from Kumarbi's skull, as Athena does from that of Zeus.

${ }^{6}$ Solmsen (1989) 413 admits that there are differences, but thinks that they are only 'details' which are, according to him, due to the large number of intermediate stages.

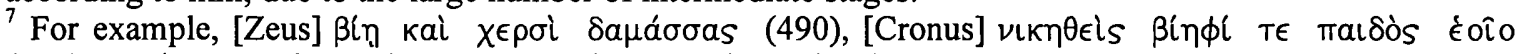
(495), Tıт⿰亻弋
} 
role. In terms of succession myth, we will see that the Theogony puts into the foreground the inter-generational problems between father(s) and son(s), which, as I discuss, are narrated in terms of the theme of the mightier son who overcomes his own father.

The Hesiodic theogony can be characterised, and differentiated from its Hurrian ancestor, by two basic distinctions: (a) Zeus, the third god, stops the cycle of succession; and, (b) succession transpires from generational strife. The reasons for these divergences cannot easily be determined, ${ }^{8}$ but I will view these differences, and the concepts embodied in them, as significant in themselves for examining the Theogony. The Theogony constructs a different mythological pattern from that presented in Hurrian myth, in order to aid the author's own teleology: that is, in order to demonstrate how and why Zeus could act preventatively to overcome the foreseeable crisis of constant generational strife by halting the perpetual process of violent succession.

Hesiod's divergence from traditional mythic structures is also in evidence when we compare his Theogony with the Babylonian myth presented in the Enuma Elish, composed around 1000 B.C. at the latest, ${ }^{9}$ and based on Sumerian cosmology. ${ }^{10}$ The dominant figure is the god Marduk. ${ }^{11}$ Tiâmat prepared an assault against Ea who had killed her husband Apsu. Ea was frightened and sought aid from her grandfather Anshar.

\footnotetext{
${ }^{8}$ Do they result from the influence of other myths, Hesiodic invention, or other factors? West (1966) ad 453-506 discusses the Near Eastern elements in the story of the birth of Zeus, and concludes that it is impossible to determine a direct relationship between the versions, and hard to say which is the original.

${ }^{9}$ Heidel (1951) 14 dates the original poem, in approximately its present form, to the First Babylonian Dynasty, 1894-1595 B.C. But Walcot (1966) 33-9 re-examines the date of the tablets of the Enuma Elish, assigning it to 1100 B.C. Pointing to the original 'loose end' of the epic, he suggests that Marduk, as the supreme god, might be a later development. Graf (1987) 90 dates the epic around 1100 B.C. West (1997) 282 points out that the Enuma Elish is not a theogony in the sense that it attempts a complete genealogy of the gods, as Hesiod does, but rather it is the story of how Marduk came to power.

${ }^{10}$ How much of the Enuma Elish can be traced to Sumerian sources cannot to be ascertained, but some gods such as Apsu, Anu and Enlil are Sumerian. See further Heidel (1951) 12.
} 
Anshar planned first to send Anu to Tiâmat, but Anu returned in terror; then he ordered Marduk to go into battle. The battle between the gods ended with the victory of Marduk, who divided Tiâmat's body into two parts to create the universe. ${ }^{12}$ Thus the succession is:

Apsu

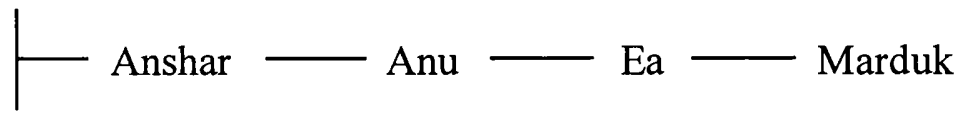

Tiâmat

The chief object of this epic seems to be to honour Marduk as the champion of the gods and creator of heaven (Tablets VI-VII), offering cosmological reasons for his supremacy. ${ }^{13}$ The design of this story is quite similar to that of the Theogony: ${ }^{14}$ the battles for sovereignty take place between gods who are related by blood, and one of the battles by which Marduk obtains supreme regal power is analogous to the Titanomachy of the Theogony. Some details correspond remarkably well: before the battle, sweet wine is served at the Court of Assembly of the gods, then their spirit is exalted (Tablet III, 1. 1367); this reminds us of Theogony 639-41, where Zeus gives nectar and ambrosia to the Hecatoncheires before the Titanomachy; then their courage is also exalted:

\footnotetext{
"I use the translation of Heidel (1951) 1-60.

${ }^{12}$ During the battle, Marduk and Tiâmat meet in single combat (Tablet IV, 1.94). As Tiâmat is a goddess of salt-sea ocean, the description of Marduk's fight against Tiâmat (flood) reminds us of Achilles' fight against the river god Xanthos (Il. 21. 233-327). Thalmann (1984) 40 emphasises the parallel between the Theogony and the Enuma Elish in Marduk's ordering of the natural elements. For other comparisons between Iliadic cosmology and the Enuma Elish, see Burkert (1992) 92-4.

${ }_{13}^{13}$ Walcot (1966) 33.

${ }^{14}$ Cornford (1952) 248 offers the strongest argument for the similarity, concluding that Hesiod's cosmological myth is derived ultimately from the Babylonian -- and the discrepancies are less striking than
} 


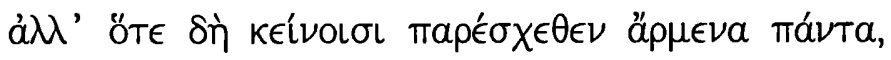

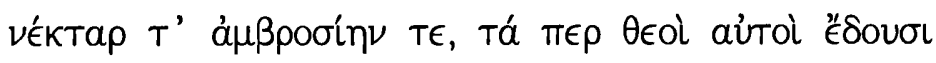

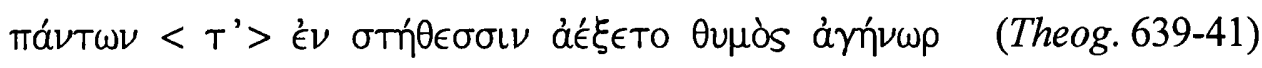

But when Zeus provided those allies with full sustenance, nectar and ambrosia, such as the gods themselves eat, and the proud spirit waxed in all their breasts (Tr. M.L. West)

Again, however, there are conspicuous differences between the Enuma Elish and the Theogony. Most notably, the succession in the Enuma Elish is not as straightforward as that of the Theogony (i.e., grandfather-father-son); in the Enuma Elish Tiâmat is the opponent of the final conqueror Marduk. She is the female ocean god, and four generations older than Marduk. The antagonism presented in the Enuma Elish exists between the first generation of gods (Apsu and Tiâmat) and an alliance of gods of the second, third and fourth generations: that is, the Enuma Elish does not present a picture of generational strife in which, as in the Theogony, a son overcomes his father.

We see that Hesiod's Theogony, for all its similarities with Near Eastern myth, offers elements unique to its own narrative. As Solmsen points out, ${ }^{15}$ there are passages which, while neither wholly traditional nor wholly original, nevertheless exhibit an old mythical manifestation in a new light, with a new interpretation. As Herodotus says, Hesiod systematised the [Greek] gods (2. 53. 2). The narrative structures of his epic highlight the value systems of his own society: to paraphrase Nagy, Hesiod, like Homer,

the coincidences; whereas West (1997) 282 thinks that the parallelism with the Hesiodic narrative is not as close as in the case of the Hurro-Hittite account. 
recreates for his listeners the inherited values that serve as the foundation for their society. ${ }^{16}$

By emphasising how Hesiod's arrangement of traditional elements differs from that of the Near Eastern sources which influenced him or his predecessors, I will demonstrate that it is these unique features - the differences - which indicate Hesiod's specific purpose. A brief comparison between the Hurrian myth and the Babylonian Enuma Elish clarifies the two main, unique, characteristics of the Theogony, which I have elaborated: (a) succession occurs through "generational strife" - specifically, that between son and father, in which the son overcomes the father; and (b) Zeus, a god of the third generation, halts the cycle of strife. I would suggest that these thematic differences reveal Hesiod's ultimate objective: to show the ascent of Zeus to permanent sovereignty in the world as an inevitable and unchallengeable fact.

This idea was undoubtedly developed by Hesiod in response to the cultural and social conditions of his age. Greek culture was emerging from the Dark Age into a period of historical awareness and maturity. It is a time of pan-Hellenisation: strong centralising forces are present in all aspects of Greek life. Local and regional myths and rites were transformed by the Panhellenic Homer and Hesiod who created a Panhellenic Olympian

\footnotetext{
${ }^{15}$ Solmsen (1949) 57. I also agree with Caldwell (1964) 186 who writes that 'Hesiod did not invent something entirely new'; cf. Walcot (1966) 31: 'Hesiod was a master and not the slave of the material at his command.'

${ }^{16}$ Nagy (1990) 42.
} 
religion. ${ }^{17}$ In response to this trend, in his Theogony Hesiod represents the powerful, unchallengeable sovereignty of Zeus.

\section{The Hesiodic accounts: the route to Zeus' victory}

In order to investigate Hesiod's logic, let us look closely at some passages in the Theogony. Hesiod presents us with several determinants which effect Zeus' final victory, such as his conspicuous physical power and wisdom. In these passages, the utmost significance is given to the method by which he rids himself of the challenge of usurpation by a son mightier than himself. The fates of his predecessors, Uranus and Cronus, can be read as lessons from which Zeus derives his strategy.

According to the text, Uranus hides his children in a hiding place within Gaia ${ }^{18}$ because he hates them:

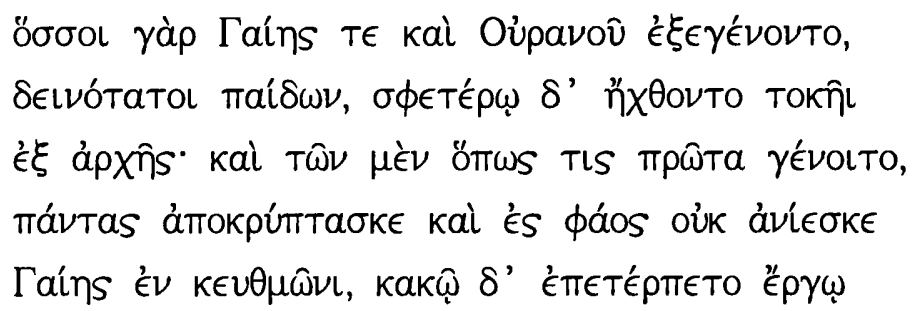

Oủpavós.

(Theog. 154-9)

For those that were born of Earth and Heaven were the most fearsome of children, and their own father loathed them from the beginning. As soon as each of them was born, he hid them all away in a cavern of Earth, and would not lead them into the light; and he took pleasure in the wicked work, did Heaven. (Tr. M.L. West)

\footnotetext{
${ }^{17}$ Clay (1989) 9; Nagy (1979) 7; O'Brien (1993) 5. The earliest attestation of the word Mavé $\lambda \lambda \eta \nu \in S$ in the sense of 'all Greeks' is in Hesiod, W.D. 528. West (1978) ad loc. comments that Homeric use of 'EMAás (Il. 2. 538) denotes only the northern Greeks.

${ }_{18}$ Solmsen (1949) 59 suggests that the word $\kappa \epsilon \cup \theta \mu \omega \dot{\nu}$ of Gaia, could be cosmological rather than physiological: Hesiodic Gaia is both the goddess and the earth as part of the cosmos.
} 


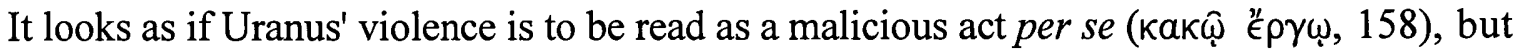
the description of his children offers a tangible reason for his hatred: Uranus fears them

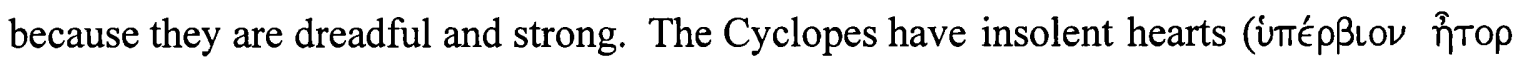
ÉXovTas, 139), and the Hecatoncheires are presumptuous children, not to be touched

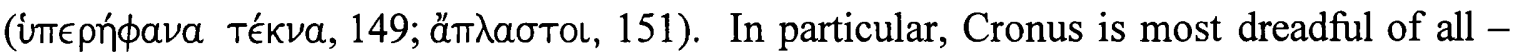
and he also hates his father:

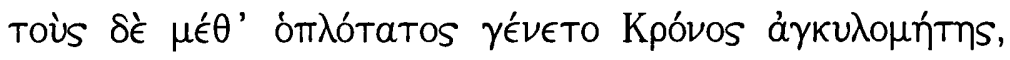

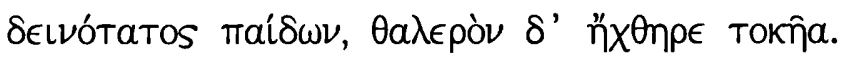
(Theog. 137-8)

After them the youngest was born, crooked-schemer Kronos, most fearsome of children, who loathed his lusty father. (Tr. M.L. West)

The connotation of these passages is that Uranus feels threatened by his sons' presumptive power. Significantly, this is almost the same implication we receive from the prophecies given to Cronus and Zeus. Unlike them, Uranus does not receive an explicit prophecy that he will be displaced by his own son, but the reasoning underlying the actions by which Cronus and Zeus avoid their children can be extended, by implication, to their predecessor: the threat of defeat at the hands of one's son. ${ }^{19}$

Uranus' precaution is unsuccessful; he is defeated by Gaia's contrivance (Soגinv

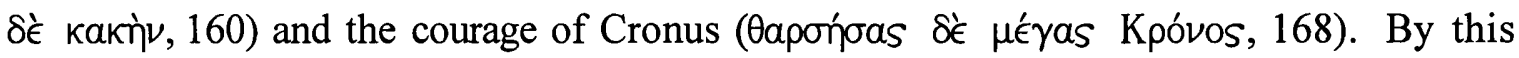
example, Hesiod offers a first lesson, demonstrating that imprisoning the children in the

\footnotetext{
${ }^{19}$ I do not agree with Détienne and Vernant (1978) 61-2, who hold that Uranus is not considered to be a king, and that the theme of the competition for sovereignty is introduced from Cronus onwards.
} 
mother's hiding place is of no use - and it is contrivance and courage with physical power which become the decisive factors for securing sovereignty.

Gaia's oracle forewarns Cronus that he will be overcome by his own son. From this point, Gaia's knowledge functions as a force driving the succession story:

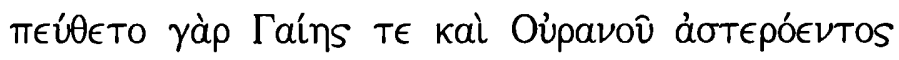

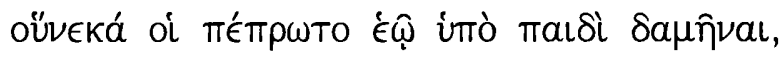

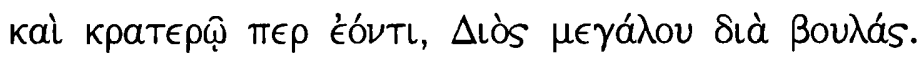

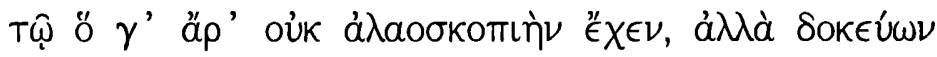

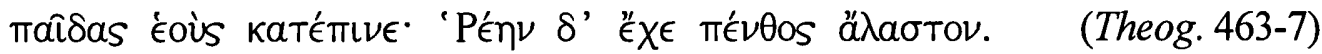

For he learned from Earth and starry Heaven that it was fated for him to be defeated by his own child, powerful though he was, through the designs of great Zeus. So he kept no blind man's watch, but observed and swallowed his children. (Tr. M.L. West)

It is not surprising that Gaia has an oracular capacity - she is said to have been the first occupant of the Delphic oracular seat. ${ }^{20}$ Hence, at the very beginning of Aeschylus' Eumenides, Gaia is honoured as the first prophet at Delphi:

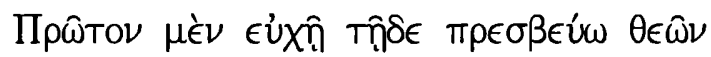

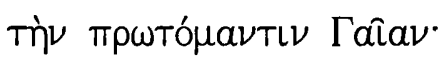

(Aesch. Eum. 1-2) ${ }^{21}$

First among the gods in this prayer I honour the first prophet, Earth. (Tr. H. Lloyd-Jones)

\footnotetext{
${ }^{20}$ West (1966) ad 463 comments that Uranus in this oracular passage appears merely as a complement to Gaia.

${ }^{21}$ Lloyd-Jones (1970) ad loc. observes that the Delphic oracle had belonged to the great goddess who played an important part in Minoan and Mycenaean religions. Sommerstein (1989) ad loc. suggests reading 'the first oracular deity (at Delphi)' rather than 'the first to prophesy (anywhere)'. Paus. 10.5.5 also writes that Earth was the first possessor of Delphi.
} 
The oracle given to Cronus does not, however, specify the name of the child who will overthrow him and, as a consequence, although the threat (from a child) is less opaque than in Uranus' case, Cronus still cannot identify his real enemy with certainty. Both Cronus and Zeus know that it is their destiny to be dethroned by one of their own sons, and both are faced with having to avert the decree of destiny by trickery. However, since Cronus does not know his actual opponent, his precautions have to be extended to all of his children - and, as a result, he misses the most important one.

Cronus has learned from the fate of Uranus that he should hide his children on his own, without his wife's involvement, because his wife could choose to support her children against her husband. As Caldwell remarks, Cronus understands that it is the mother as much as the son who is his enemy. ${ }^{22}$ His children must be separated from their mother, but, despite this knowledge, he still cannot avoid the inevitable alliance between mother (Rhea) and son (Zeus).

There are several formulaic correspondences between the story of Cronus' attempt to swallow Zeus, and Zeus' swallowing of Metis: ${ }^{23}$

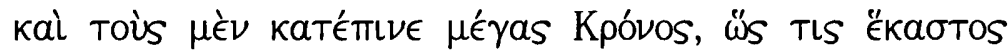

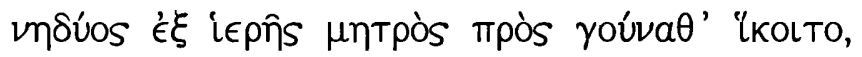

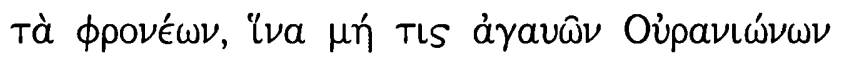

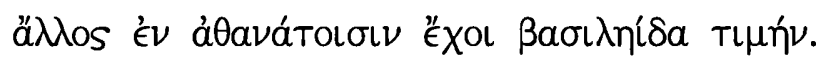

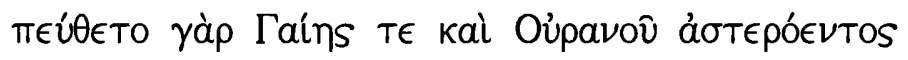

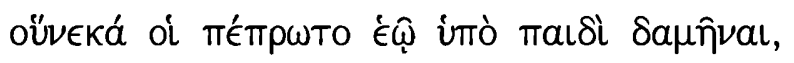

\footnotetext{
${ }^{22}$ Caldwell (1989) 161.

${ }^{23}$ Angier [Sowa] (1964) 340 notes the similarities and explains that they indicate oral variants of one typescene. Thalmann (1984) 43-4 also points out the similar pattern of Gaia's role in the two passages, stressing the creation of expectation by the repeated motifs.
} 


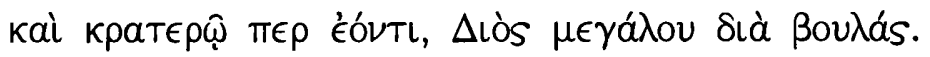

(Theog. 459-65)

The others great Kronos swallowed, as each of them reached their mother's knees from her holy womb. His purpose was that none but he of the lordly Celestials should have the royal station among the immortals. For he learned from Earth and starry Heaven that it was fated for him to be defeated by his own child, powerful though he was, through the designs of great Zeus.

(Tr. M.L. West)

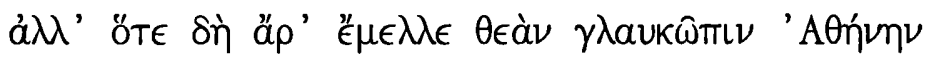

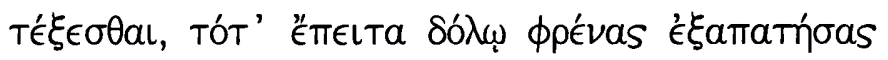

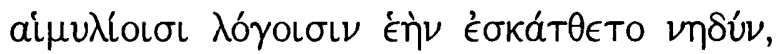

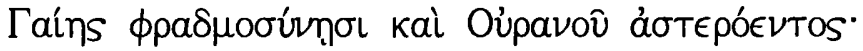

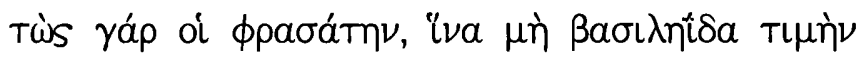

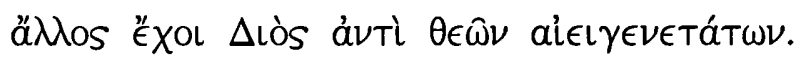

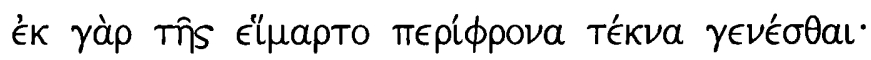

But when she was about to give birth to the pale-eyed goddess Athene, he tricked her deceitfully with cunning words and put her away in his belly on the advice of Earth and starry Heaven. They advised him in this way so that no other of the gods, the eternal fathers, should have the royal station instead of Zeus. For from Metis it was destined that clever children should be born. (Tr. M.L. West)

First, in both cases Uranus and Gaia represent their kingship through the same phrase

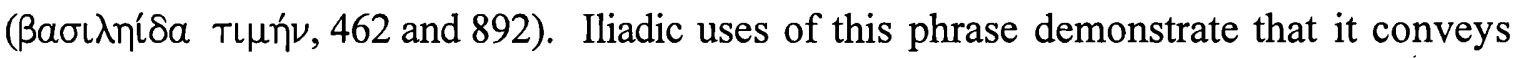
not only the idea of sovereignty in the abstract, but also the concrete meaning of 'estate':

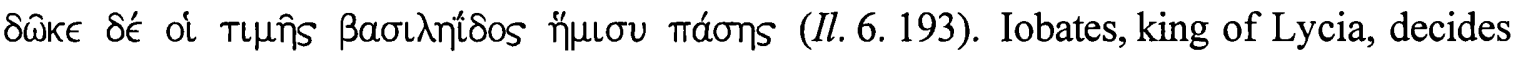
to give half of his estate to Bellerophontes as reward for Bellerophontes' heroic exploits in killing the Chimaera (6. 173-83), defeating the Solymoi (6. 184-5), destroying the Amazons (6. 186) and, finally, fighting against the best warriors of Lycia (188-90). Like Bellerophontes' fame, Uranus' kingship is primarily based on his physical strength, as the

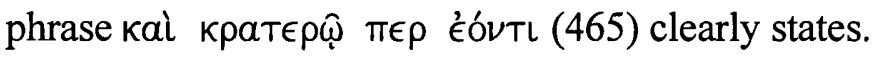


Second, the act of swallowing is expressed by the same phrase: 'put it/her in his

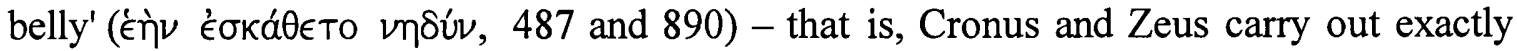
the same action in order to solve their problem. I suggest, however, that the duplicate phrasing effectively emphasises the difference in what follows: Cronus spares the mother (leaving her free to aid her son), while Zeus eliminates the threat of the mother for good and at the same time appropriates her intelligence. ${ }^{24}$

In the account of Zeus' swallowing of Metis, a decisive factor in his success is

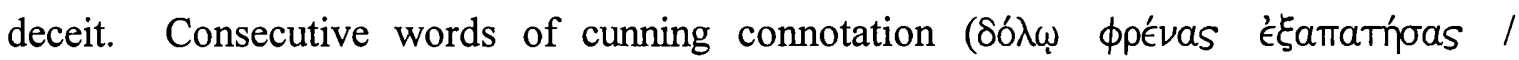

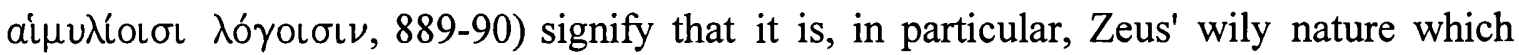
will enable his successful acquisition (and maintenance) of power. Of course, Cronus too

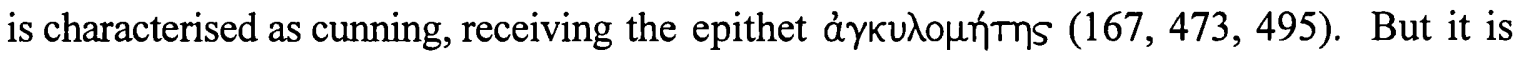
Zeus who receives the epithet $\mu$ †тเoєis (the counsellor, 457). With these two epithets, Hesiod differentiates the nature of Cronus and Zeus' intelligence. ${ }^{25}$ The difference is, apparently, not based on moral grounds: as far as the account of the swallowing of Metis is concerned, Zeus' metis has nothing to do with any ethical idea such as justice. ${ }^{26}$ The

\footnotetext{
${ }^{24}$ Zeitlin (1995) 61 and 67 thinks that Cronus' swallowing his children imitates pregnancy; consequently Zeus' triumph over Cronus represents the victory of the son over the father, and also the triumph of the father over the mother as a higher form of reproduction. Zeus' swallowing of Metis is a doubly significant event: Zeus also gains intelligence by swallowing her, as will be discussed in the next section of this chapter.

${ }^{25}$ Thalmann (1984) 42 admits that epithets are mostly conventional expressions, but also notes that 'the recurrence of these phrases (sc. epithets of $\mu \eta^{\prime} \tau \mathrm{s}$ ) in the Theogony is so persistent and patterned that Hesiod must surely be manipulating their sounds and meanings'.

${ }^{26}$ In W.D. 257, Hesiod, with the introduction of Dike as a new goddess, proclaims that Zeus' rule is one of justice. However, in the Theogony, Zeus' justice is not emphasized. For example, the story of Prometheus (535-69) shows that Prometheus, not Zeus, seems to have justice on his side. I do not follow Lloyd-Jones (1983) 35 who suggests that 'Cronus gave Zeus provocation, so Zeus overthrew Cronus; since then justice has sat beside his throne.' In the Theogony, the Hesiodic idea of justice seems to be expressed in the vengeance of Gaia. Gaia is also related to the Erinyes who ensure that no evil deed goes unpunished. Janko (1992) ad 16. 384-93 comments that the idea of the justice of Zeus is already found in the Iliad (16.
} 
significance is that Zeus' cunning is realised in an innovation which escaped Cronus; namely, producing a child by parthenogenesis. But the swallowing of Metis gives him the scope to create stability and order, as is discussed later in this section.

Throughout the Theogony, Gaia is the figure predominantly characterised by

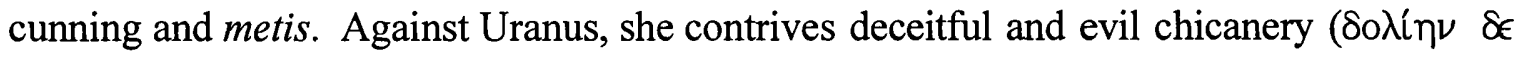

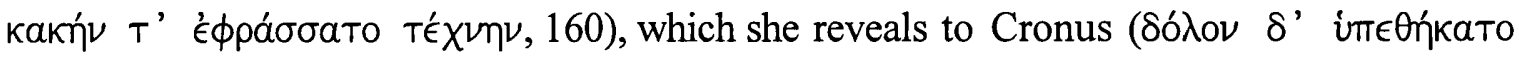

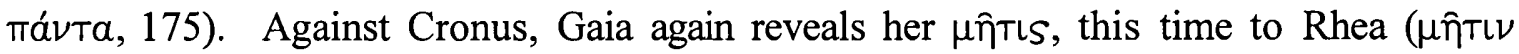

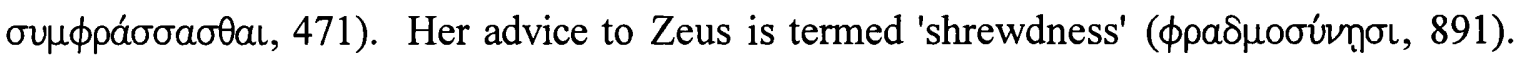
Gaia is undoubtedly a king-maker, but her actions do not extend beyond words: the recipient needs the courage and. cunning required to carrying the deeds through. Interpreting her words and finding the means to overcome the difficulty involved in putting them into action are decisive factors in obtaining sovereignty. ${ }^{27}$

The prophecy given to Zeus is somewhat ambiguous: the precise implication of what Gaia and Uranus said to Zeus is unclear. I cite the passage again:

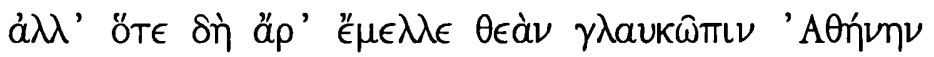

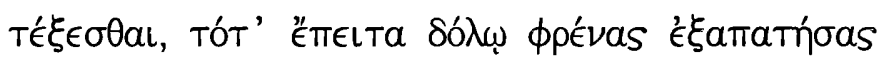

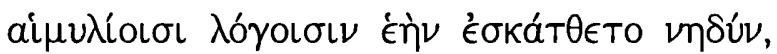

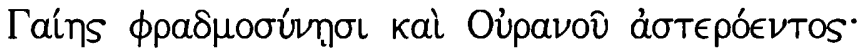

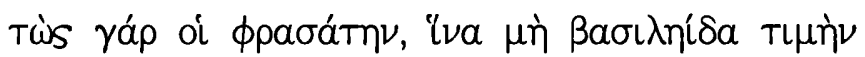

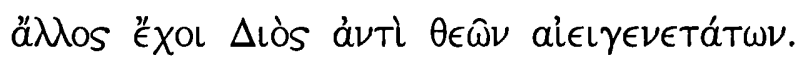

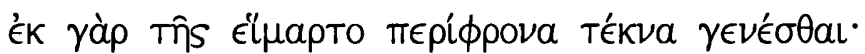

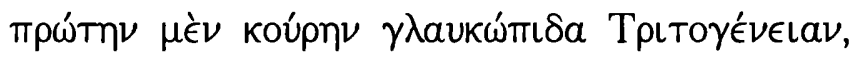

384-93. Solmsen (1949) 26 offers the unique and unconvincing idea that a curse runs through the family of Zeus; see also Solmsen (1982) 4, n. 8.

${ }^{27}$ According to the analysis of folktale by Propp (1968) 79-80, Gaia could be classified as 'the helper' who gives the solution to difficult tasks and helps the hero to move on to the next step in the narrative. 


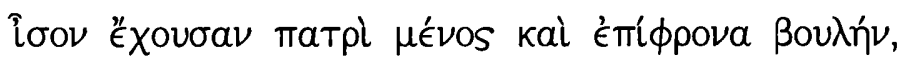

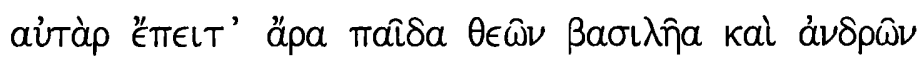

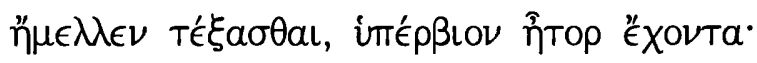

(Theog. 888-898)

But when she was about to give birth to the pale-eyed goddess Athene, he tricked her deceitfully with cunning words and put her away in his belly on the advice of Earth and starry Heaven. They advised him in this way so that no other of the gods, the eternal fathers, should have the royal station instead of Zeus. For from Metis it was destined that clever children should be born: first a pale-eyed daughter, Tritogeneia, with courage and sound counsel equal to her father's, and then a son she was to bear, king of gods and men, one proud of heart.

(Tr. M.L. West)

We remember that Zeus is not necessarily Gaia's choice for eternal king of heaven. After Zeus destroys the Titans, Gaia gives birth to Typhoeus, her youngest child in the Hesiodic version (821). ${ }^{28}$ We note that the youngest son is always the greatest threat to paternal sovereignty, as in the case of Uranus and Cronus. Thus, Typhoeus should have continued the chain of succession by overthrowing Zeus' rule. As the promoter of succession (and attempts to change the world order), this particular succession could be read as Gaia's original plan. Indeed, Hesiod mentions the possibility of Typhoeus' overthrowing Zeus - though it is narrated in an unreal conditional sentence:

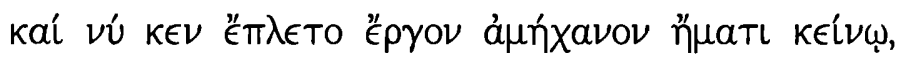

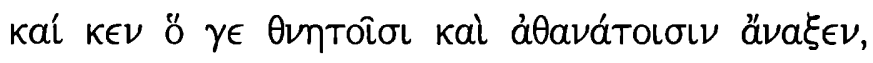

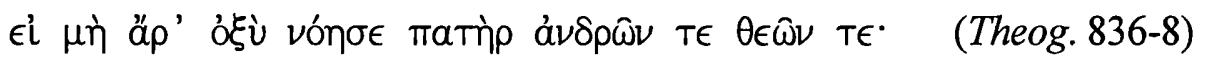

A thing past help would have come to pass that day, and he would have become king of mortals and immortals, had the father of gods and men not taken sharp notice.

(Tr. M.L. West)

\footnotetext{
${ }^{28}$ Typhon is a son of Hera in the Homeric Hymn to Apollo (349-52).
} 
This further reference to a son overthrowing his father and ruling over gods and men (837) emphasises the Hesiodic logic of succession, and the phrase $\eta_{\mu a \tau L} \kappa \in i \nu \omega$ (836) makes palpable the crisis facing Zeus. The long account of Typhoeus' strength (823-35) and his battle with Zeus (839-68) emphasises how strong an enemy Typhoeus is for Zeus. Typhoeus' lack of success in a battle based purely on violence and physical power also anticipates the introduction of the motif of successful intellectual deception.

After Zeus' strength and courage are proved in the battles against Typhoeus and the Titans, Gaia tests another of Zeus' abilities. ${ }^{29}$ In the passage about Metis, which immediately follows the battles (886-900), Gaia examines whether Zeus is as well qualified in cunning and deceit as he is in physical strength. ${ }^{30}$ As the example of Uranus shows - destroyed by the contrivance of Gaia (160) and the courage of Cronus (168) Zeus must prove himself wily enough to avert the next danger that Gaia sends.

Gaia sets tests and Zeus takes the most resourceful decisions in the light of the advice given him, which implies that he is in danger of becoming the father of a son who will be 'proud of heart'. Gaia reveals the future to Zeus, just as she did to Cronus, then observes how Zeus reacts. She judges Zeus' cunning: how will he deal with this exigency?

Zeus passes the test, and Hesiod shows that Zeus, unlike his predecessors, possesses all the assets needed for successful sovereignty. He has learned the lesson/s from his predecessors' failures: from Uranus' case he learns that the son must be separated

\footnotetext{
${ }^{29}$ Stevenson (1992) 432 points out that, where superiority is established by force, its maintenance tends subsequently to become a matter of emphasising morality, legality, etc. I agree with Stevenson in general, but I do not think that Zeus' morality is emphasised here.

${ }^{30}$ Clay (1989) 13 suggests that, after Zeus' victory over Typhoeus, Gaia finally admits defeat and renounces her opposition by advising Zeus of the danger involved in marriage to Metis. I think that Gaia's
} 
from his mother, and from Cronus' case he learns that separation is not enough - the existence of the mother herself is also dangerous. It is no solution to put his dangerous children inside either his wife's body or his own; rather, as his wife is the more dangerous enemy, he has no choice but to swallow his wife.

In spite of conspicuous similarities between the prophecies given to Zeus and Cronus, a slight but explicit difference in phrasing is noticeable:

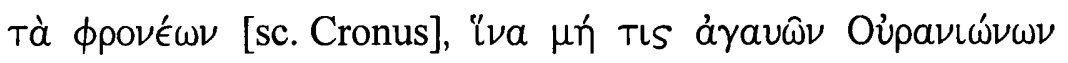

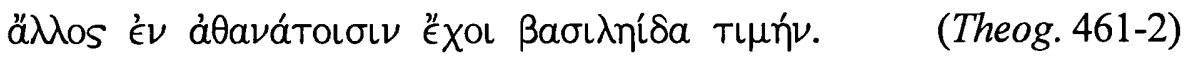

His purpose was that none but he of the lordly Celestials should have the royal station among the immortals. (Tr. M.L. West)

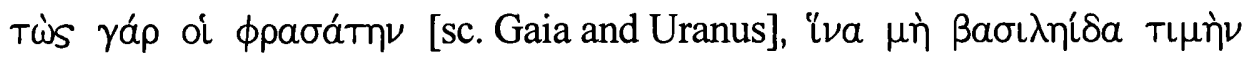

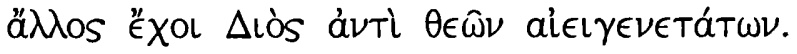

(Theog. 892-3)

They advised him in this way so that no other of the gods, the eternal fathers, should have the royal station instead of Zeus.

(Tr. M.L. West)

In Cronus' case, the threat that someone might usurp his kingship is narrated as Cronus' own notion; but in Zeus' case, it is the concern of Gaia and Uranus. The phrasing suggests that Zeus's security is now Gaia's care: but why has Gaia changed her policy? We remember that the overthrow of the kingship was motivated by revenge. Gaia

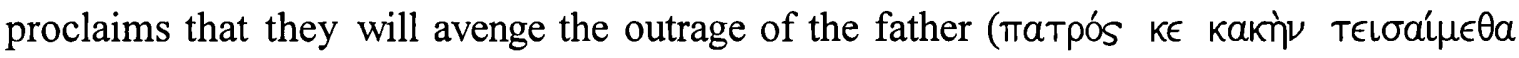

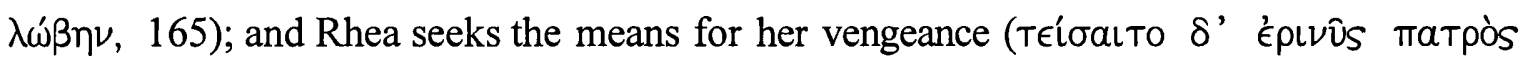
she offered Cronus. 


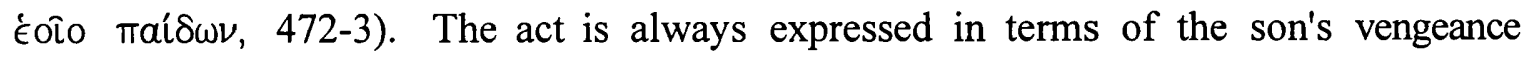
against the father, not the wife's vengeance against her husband/father; this implies that, although vengeance is primarily motivated by the mother, she needs her son to realise it. Having lost her last son (Typhoeus) in battle, Gaia has no other son to challenge Zeus' power. Thus she begins to change her attitude toward Zeus, and he responds properly to her prophecy.

Once a mighty child were born, ${ }^{31}$ Zeus would meet the same fate as Uranus and Cronus. The stories of Uranus and Cronus are intended to focus attention on Zeus' victory against the odds. Zeus terminates Metis, the potential architect of his downfall, by swallowing her and putting her inside his own body. In swallowing Metis, Zeus takes over Metis' function as a mother, and, as Austin suggests, ${ }^{32}$ takes control of the reproductive process. Zeus proves himself the superior god by devising this plan and carrying it through by beguiling 'intelligent' Metis with his deceitful words (889-90). The myth of Metis narrates the final resolution of the age-old struggle between the father and an alliance of mother-with-son: Zeus' success signifies that the cosmic evolutionary process and the Hesiodic narrative process are reaching their similar goals.

\section{The Birth of Athena}

\footnotetext{
${ }^{31}$ Zeus already has two children, Ares and Hephaestus, but the one is mentally immature and dangerously violent, the other is lame. Ares is despised by the other gods in the Iliad: e.g., 5. 385-91, 5. 846-898, 21.

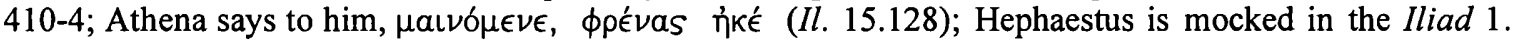
597-9.

${ }^{32}$ Austin (1989) 81 .
} 
The integrity of Theogony 886-900, the passage about the swallowing of Metis and the birth of Athena, has been rejected by many scholars. ${ }^{33}$ But there is much support for judging the passage authentic. ${ }^{34}$ I suggest that the passage is genuine because it touches on one of the most important themes of the poem, namely, the threat from a son who is mightier than his father, and Zeus' avoidance of this threat. ${ }^{35}$ My close reading of this passage aims to demonstrate that this theme runs through, and weaves together, the structure of the poem as a whole. ${ }^{36}$

Integral to this unity ${ }^{37}$ is the narration of the delivery of Athena. Structurally, we notice a tripartite ring composition:

(a) swallowing of Metis; mention of the birth of Athena (888-91);

(b) prophecy surrounding Metis; mention of the birth of a mighty son (891-4);

(a) swallowing of Metis, mention of the birth of Athena and a son (895-900).

The prophecy - that is, the warning of the birth of a mighty son from Metis - forms the core of this ring composition. Significantly, we note that Athena is not mentioned in the prophecy; rather, the prophecy emphasises - a central idea - the potentiality of Metis,

\footnotetext{
${ }^{33}$ Jacoby (1930) 41-2 marks lines 886-900 as an interpolation; Solmsen (1949) 67-8 rejects the passage because (a) Themis is Zeus' first wife in Pindar, (b) Zeus' giving birth to Athena from his head is inconsistent with Metis as her mother, and (c) Athena as daughter of Zeus and Wisdom appears to be later allegorical or semi-allegorical theology. West (1966) ad 886-900 suggests the possibility of interpolation, but leaves the question of authenticity open.

${ }^{34}$ Schmid-Stählin (1929) 1.1.281; Cook (1940) 3. 343-4; Brown (1952) 131. Thalmann (1984) 198 n. 22 persuasively refutes Solmsen's argument, pointing out that Solmsen is dependent on Pindar's account, but Pindar might have changed this traditional story to suit his own purposes.

${ }^{35}$ In antiquity, the head is not the seat of cognition, so we must reject the Stoic interpretation of Athena's birth from the head of Zeus to signify that she is connected with intellect. Athena's intellect should be linked with Metis. See Pope (1960) 114.

${ }^{36}$ Brown (1952) 142 concludes that the peculiar birth of Athena is a Hesiodic innovation. I admit that Athena's birth from Zeus' head is especially important for his rule, but it seems difficult to infer this story to be Hesiodic invention only for that reason. The story of the birth of Athena should be considered together with two other peculiar births in the Theogony: Aphrodite, born from the sexual organs of Uranus, and Hephaestus, born from Hera without sexual union.
} 
who can bear a child stronger than Zeus. The purpose of swallowing Metis is, primarily, to get rid of this unnamed potential son. ${ }^{38}$

In myth, Zeus overcomes two similar threats to his power - the birth of sons from Thetis and from Metis. The existence of duplicate oracles in the mythic material indicates the seriousness and significance of the apparently inescapable danger facing Zeus. Hesiod truncates the potentiality of Thetis, mentioning only briefly that she gives birth to Achilles (1006-7); but there are conspicuous similarities between Metis and Thetis: both goddesses are sea-powers; both change their shapes; both are destined to bear a son who will overcome his father; and, in both cases, this danger is averted by an oracular warning and divine guile. It is intriguing that, while Hesiod places the story of Metis at the centre of his poem and ignores Thetis' potentiality, Homer, on the other hand, remains silent about Metis' potentiality and the birth of Athena from Zeus' head. This does not appear simply coincidental. As I argue, it is the choices - the variations in treatment of their material - which the poets make that are significant for a teleological understanding of their poems. ${ }^{39}$ That is, Homer and Hesiod adapt this material to fit their themes and structures, so that, in the case of the epic, Homer develops the potentiality of Thetis because his theme is the heroic destiny of Achilles; similarly, Hesiod puts in the

\footnotetext{
${ }^{37}$ I agree with West (1966) ad 886-900, who regards this passage as 'a composite myth'.

${ }^{38}$ Brown (1952) 134 suggests that the unnamed brother of Athena would be considered by Hesiod as a culture-hero type of god. I do not see any reason why the unborn son should be such, although, as Brown claims, in later myth the culture-hero types - Hephaestus, Hermes or Prometheus - attend Zeus' delivery with their axes.

${ }^{39}$ One reason for the Iliad's silence about the story of Metis could be, of course, the physically abnormal event of Athena's birth from Zeus' head. Cf. Griffin (1977) 40-41 who suggests that bizarre features are not tolerated in Homer. Many scholars think that Homer knew the myth of Athena's birth (for example, Wilamowitz 1955: 1. 333; Cook 1940: 3. 737; Gantz 1993: 83), on the grounds that, when Ares reproaches Zeus for letting Athena do as she pleases, it is implied that Zeus does so because he bore her
} 
foreground the story of Metis in order to connect it with the birth of Athena - an important thematic focus.

The variant form of the story cited by Chrysippus (Hes. fr. dub. 343 M.-W., Theogony lines 929a-t in Evelyn-White's edition) is generally deemed inauthentic. ${ }^{40}$ The purpose of Chrysippus' citation is to discuss the place of wisdom, and, although the variant may not be genuine, it does provide us with some interesting, supplementary, information:

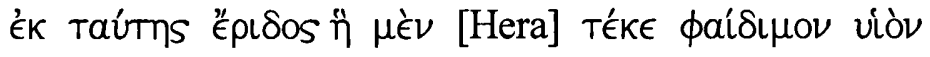

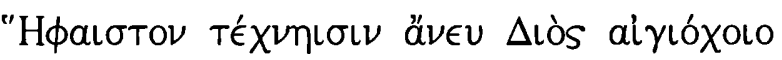

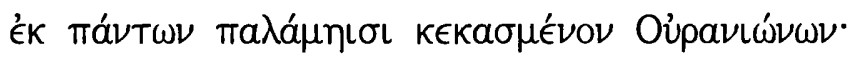

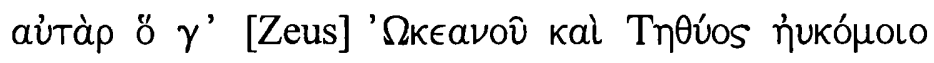

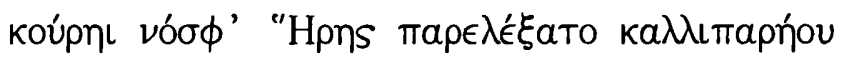

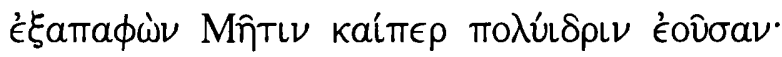

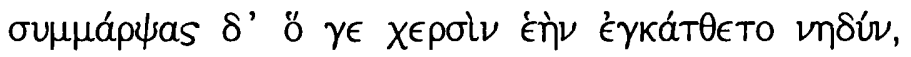

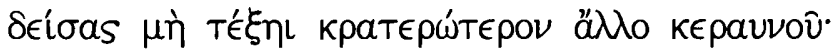

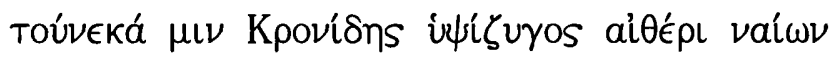

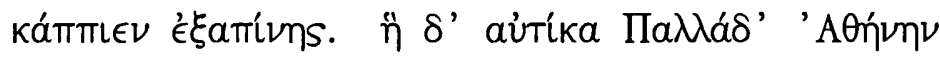

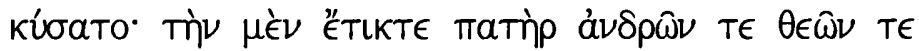

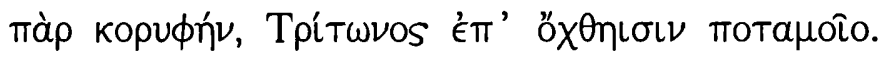

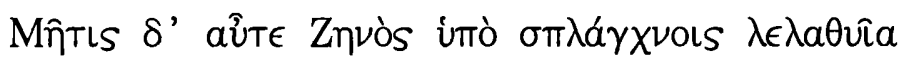

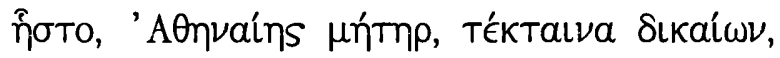

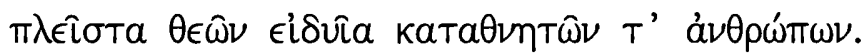

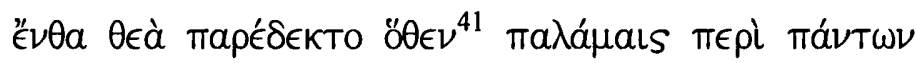

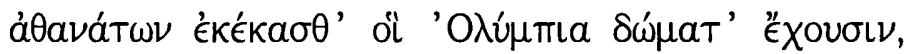

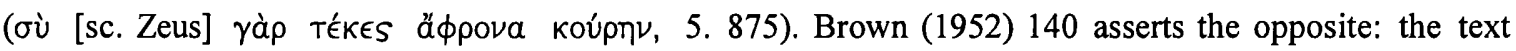
(5.875) only implies Zeus' paternal relationship to mankind.

${ }^{40}$ Solmsen (1949) 68, n. 225; Brown (1952) 131, n. 3. The source of Chrysippus' fragment is not known with any certainty. In the introduction to the fragment, which is added by the second hand in the manuscript, the passage ( $\tau \iota \nu \omega \hat{\omega} \nu \mu \dot{\epsilon} \nu \ldots . T \omega \nu \omega \hat{\nu} \delta \dot{\epsilon})$ could be understood as referring to several copies of the Theogony. Solmsen (1982) 20, n. 65 suggests the possibility that these words refer to different "editions." It is difficult to date this version. See also West (1966) ad 886-900.

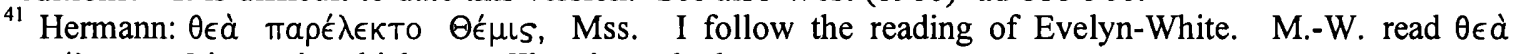
паре́ $\epsilon \epsilon \kappa$ To $\Theta \dot{\mu} \mu \mathrm{s}$, in which case, Themis made the aegis. 


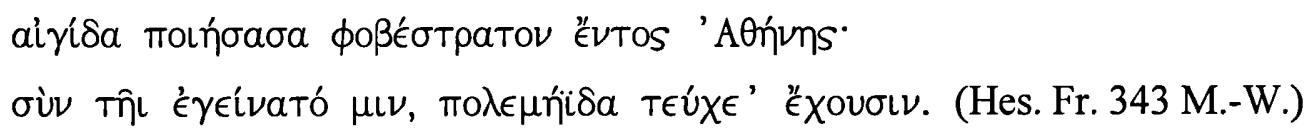

But Hera was very angry and quarrelled with her mate. And because of this strife she bare without union with Zeus who holds the aegis a glorious son, Hephaestus, who excelled all the sons of Heaven in crafts. But Zeus lay with the fair-cheeked daughter of Ocean and Tethys apart from Hera ... deceiving Metis (Thought) although she was full wise. But he seized her with his hands and put her in his belly, for fear that she might bring forth something stronger than his thunderbolt: therefore did Zeus, who sits on high and dwells in the aether, swallow her down suddenly. But she straightway conceived Pallas Athene: and the father of men and gods gave her birth by way of his head on the banks of the river Trito. And she remained hidden beneath the inward parts of Zeus, even Metis, Athena's mother, worker of righteousness, who was wiser than gods and mortal men. There the goddess (Athena) received that whereby she excelled in strength all the deathless ones who dwell in Olympus, she who made the host-scaring weapon of Athena. And with it (Zeus) gave her birth, arrayed in arms of war.

(Tr. H. Evelyn-White)

Kauer, who attempts a close comparison of this fragment with the Theogony, concludes that Chrysippus' quotation is a fragment of a lost epic poem on the theme of Metis and the birth of Athena, and it has parallels with Hesiod's work, but can be viewed as independent from it. ${ }^{42}$

Kauer is correct to emphasise that Hesiod innovates in the order of Hephaestus and Athena's births. ${ }^{43}$ Although it is difficult to say which text (the Theogony or the fragment) is older, ${ }^{44}$ the fragment seems to draw on an older tradition, namely the

\footnotetext{
${ }^{42}$ Kauer (1959) 42-3. I agree with Kauer's conclusion, although I do not follow some of her argument, as is discussed below.

${ }^{43}$ Kauer (1959) 34-5.

${ }^{44}$ Kauer (1959) 35 leaves it open as to which text is older. According to her, there are two possibilities: (a) both texts were composed by Hesiod; or (b) the fragment was composed by a minor rhapsode. Solmsen (1949) 68, n. 225 rejects the idea that Chrysippus quoted from a pre-Hesiodic epos. But the concept of 'interpolation' does not necessarily mean only that the interpolation is newer than the main text.
} 
narration of events in the following order: (a) the quarrel between Zeus and Hera; ${ }^{45}$ (b) the birth of Hephaestus; (c) the birth of Athena. In the Theogony, the birth of Hephaestus (927-8) is the result of the quarrel between Zeus and Hera, and the birth of Athena (9246) is treated as a separate event, which is narrated before the birth of Hephaestus. Kauer is surely right to juxtapose the similar qualities of Hephaestus and Athena, for they present complementary features: the former is a son born from the mother without a father, the latter is a daughter born from the father without a mother. What is distinctive about fr. 343 is that it says little about the connection between their births, and links Athena's birth with the prophecy about Metis.

The prophecy surrounding Metis is mentioned in the fragment, but is not integrated with the birth of Athena. Two reasons are given for Athena's birth - the quarrel with Hera (v. 5) and the prophecy of Metis (v. 8) - but the latter appears to be additional and less important. The significance of Hesiod's account is that it involves separating the birth of Hephaestus from that of Athena: he strips away other material to place emphasis on the prophecy about Metis' potentiality, the swallowing of Metis, and the birth of Athena. ${ }^{46}$

\footnotetext{
${ }^{45}$ The quarrel is related in the Melampodia (fr. 275): Zeus and Hera had an argument about whether the man or the woman derived most pleasure from sexual intercourse. Teiresias judged that woman did: Hera was so angry that she struck him blind, and Zeus so pleased that he gave him the gift of prophecy. See West (1966) ad 886-900.

${ }^{46}$ I do not follow Kauer (1959) 35, who suggests that the main purpose of Hesiod's changing the order (putting Athena's birth earlier than Hephaestus' birth from Hera) is to put more emphasis on Zeus' genealogy rather than on that of Hera. Caldwell (1989) 187 suggests that there is another significant Hesiodic innovation: making the threat to Zeus come not from his son but from the monster Typhoeus. Cf. Chapter V, Section 3. However, I consider that the threat of an ambitious son prevails through Hesiod, and that the challenge of Typhoeus can also be read as an example of generational strife, since he is, in the Theogony, a son of Gaia - the grandmother of Zeus.
} 
In contrast, in the Homeric Hymn to Apollo the quarrel between Zeus and Hera receives the emphasis (307-30): Hera gives birth to Hephaestus, and then Typhon, because Zeus produced Athena:

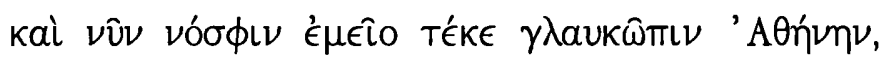

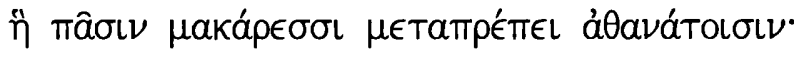

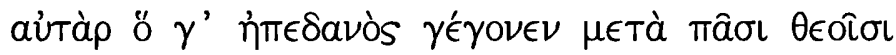

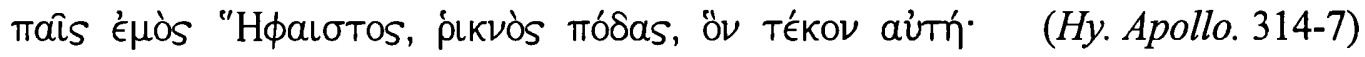

And now apart from me gave birth to gray-eyed Athena, who excels among all the blessed immortals. But my son, Hephaestus, whom I myself bore has grown to be weak-legged and lame among the blessed gods.

(Tr. A. Athanassakis)

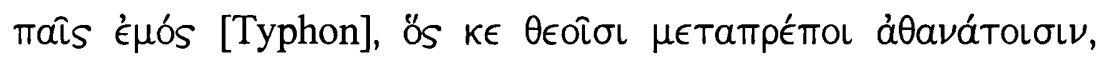

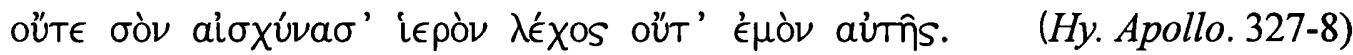
And now, I shall contrive to have born to me a child who will excel among the immortals.

And to our sacred wedlock I shall bring no shame (Tr. A. Athanassakis)

In this version there is no mention of Metis' potentiality; rather, anger is the main motif. ${ }^{47}$ Comparison with these two stories (Chrysippus' fragment and the Hymn to Apollo) demonstrates that the Hesiodic account is designed to focus - structurally and thematically - on the significance of the prophecy about Metis, to the exclusion of other mythic variants which might lessen the impact and centrality of his theme.

According to a scholion (bT ad $M .8 .39$ ) of unknown data and origin, Metis is already pregnant with Athena by the Cyclops Brontes when Zeus swallows her: 


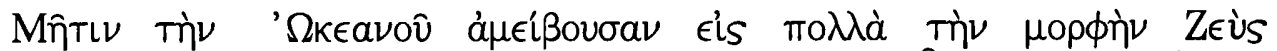

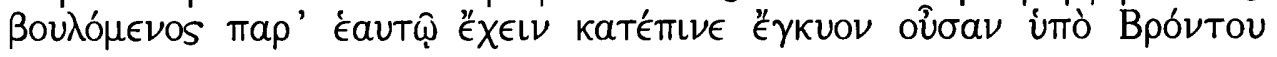

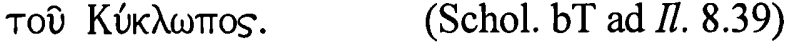

Zeus, wishing to keep her by himself, swallowed Metis, daughter of Oceanus, who changed into various shapes, and who was pregnant by the Cyclops Brontes. (My translation)

Brontes is one of the three Cyclopes, the children of Uranus and Gaia (Theog. 140), who gave thunder and the thunderbolt to Zeus (Theog. 141). Brontes is particularly associated with thunder ( $\dot{\eta} \beta \rho \circ \nu T \eta \dot{)})$, as his name indicates. If we link this account with verse 929i of the variant cited by Chrysippus (Hes. fr. 343 M.-W.), a remarkable analogy between Thetis and Metis becomes overt, and clarifies the ambiguous accounts of Hesiod about Metis. Verse 929i states,

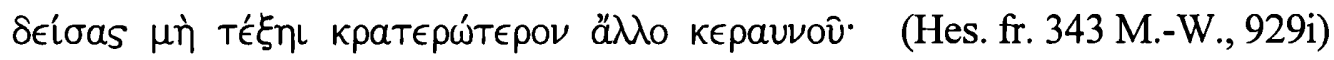

for fear that she might bring forth something stronger than his thunderbolt (Tr. H. Evelyn-White)

Zeus fears that Metis will give birth to somebody mightier than the thunderbolt. So, Metis, as well as Thetis, has the potential to bear a son mightier than his father.

In Thetis' case, Zeus avoids the danger of begetting a son mightier than himself by making Peleus, a human, her husband. But in Metis' case, her impregnator is a Cyclops who provided Zeus with his strongest weapon, the thunderbolt. Once Metis gives birth to a son who is mightier than his father (that is, mightier than the thunderbolt), Zeus will

\footnotetext{
${ }^{47}$ Cf. Chapter V, Section 4.
} 
surely be defeated. Therefore he must swallow Metis, and thereby swallow the thunderbolt, too, with which his supremacy might otherwise have been challenged.

This explains the ambiguities in the Hesiodic account of Metis. First, the father of the unnamed son of Metis is not apparent in Hesiod. Although Hesiod seems to imply that the father is Zeus, a more subtle reading which draws on variants in the mythic corpus, could imply that Brontes - Thunder - is the father of this unnamed son. Second, it is unclear in Hesiod how mighty the son is. Hesiod says that the son is to have an

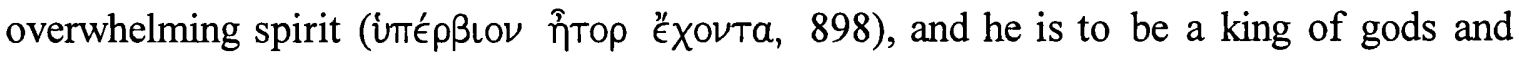
men (896). Is he to be mightier than Zeus?

Hesiod's primary concern is his intention to emphasise the birth of Athena and the importance of the relationship between Athena and Zeus. That is, if he had mentioned that Brontes was the father of the unnamed mighty son, this would weaken the link between Athena and Zeus. Athena's genealogy is the indispensable factor for Hesiod, ${ }^{48}$ and the blood connection between Zeus and Athena is of primary, vital significance for Zeus' solution to the problem of generational strife. ${ }^{49}$

\footnotetext{
${ }^{48}$ I agree with Zeitlin (1995) 69 that genealogy is an effective means by which myth can posit a coherent scheme of relations and affinities.

${ }^{49}$ The story of her unusual delivery was accepted by later poets: for example, Pindar (Ol. 7. 33-9) and Aeschylus (Eum. 736-8). The importance of the father-daughter relationship of Zeus and Athena seems to have been widely recognised. In the earliest artistic representation of Athena's birth (a relief amphora from Tenos, dating to the first half of the seventh century), Zeus is attended by Eileithuia: the implication is that Zeus' own labour produces the birth. In Attic black figure painting, the motif of Hephaestus' role became popular: Athena is released from the head of Zeus by the blow of an axe held by Hephaestus (or, sometimes, by Prometheus or Hermes). It is unclear how old the motif of Hephaestus' cleaving Zeus' head is. These paintings presuppose that the birth of Hephaestus is prior to that of Athena. Cf. LIMC, Athena 346, 347. For the Hurrian parallel (Kumarbi gives birth to KA.ZAL from his head), cf. n. 5 above. Cook (1940) 733 links this myth and artistic representation with the ritual of the Dipolieia where, in order to safeguard the fertilising power of the sky-god, old kings were killed, honoured as embodiments of Zeus, and Zeus was thus believed to be born afresh. Burkert (2001) 91-2 notes the ritual of 'yoking the oxen' in which the plough-ox is unhitched from the plough and dies, felled by the blow of an axe in the sanctuary
} 
As Brown suggests, ${ }^{50}$ if Athena had been born from her mother in the normal way, she, as well as her (potential) brother, would have represented a threat to Zeus' sovereignty. Since it is crucial for Zeus to subordinate his children to himself, his cunning contrivance to give birth to her himself provides the precise response that will safeguard his supremacy: ${ }^{51}$ in this way, Zeus eliminates Athena's connection with her (potentially dangerous) mother Metis, and recruits her to his cause. The image of the unnatural birth of Athena reflects the ambivalent nature of the relationship between Zeus (now father and mother?) and his daughter.

The swallowing of Metis, and her advice from inside Zeus, justifies Zeus' epithet $\mu \eta т \iota \iota_{\epsilon} s:$ Zeus is, quite literally, filled with metis. As Caldwell writes, ${ }^{52}$ we are aware of Hesiod's progressive endeavour to elevate Zeus from god of brute force to deity of wisdom. One way in which this essential aspect of Zeus' rule is conveyed can be seen in Hesiod's choice of names for Zeus' wives and children: the Muses and Horae, Dike and Eirene characterise Zeus' new world order. Metis, we see, is likewise meaningful on various levels: in the apparently crude myth of the swallowing of Metis-the-mother, we see Zeus acquiring metis-intelligence. ${ }^{53}$

The logic can be traced back, once again, to the prophecy in which Hesiod elucidates why the swallowing of Metis renders Zeus' rule invincible:

of Zeus and Pallas. According to Burkert, this ritual, which ends with the return of the procession from the sea, shows the transit from an act of violence to the community of law.

${ }^{50}$ Brown (1952) 134.

${ }^{51}$ I do not agree with Caldwell (1989) 186-7 who writes that Zeus is victorious because he is, in the Theogony, not so much the archetypal father who suppresses his sons (as are Uranus and Cronus). That is, Zeus does not destroy Apollo, Ares or Hephaestus. Zeus, however, eliminates his mighty son by swallowing Metis, which undoubtedly shows the archetypal aspect of his nature.

${ }^{52}$ Caldwell (1989) 179. 


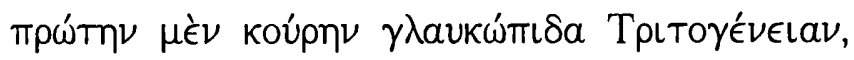

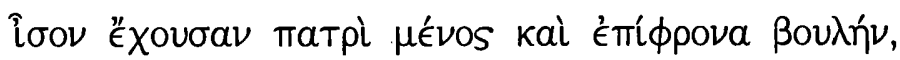

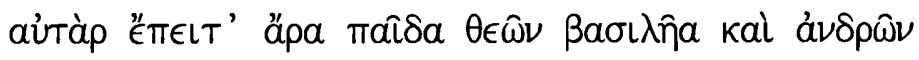

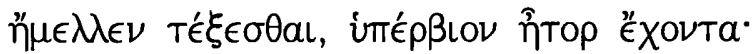

(Theog. 895-8)

first a pale-eyed daughter, Tritogeneia, with courage and sound counsel equal to her father's, and then a son she was to bear, king of gods and men, one proud of heart. (Tr. M.L. West)

The birth of an unnamed son who would be mightier than Zeus is transformed into 'the birth of a daughter equal to her father in power and wisdom' (895-6). The juxtaposition of Athena and an unnamed son is pivotal for expressing the mechanics of this decisive transformation of the threat of generational strife: the repeated threat from a mighty son has been thwarted, and a new relationship between father and daughter has begun. As Arthur points out, ${ }^{54}$ the father-daughter unity of Zeus' rule presents a moment of dynamic stasis. Zeus cuts the old, original bond between mother and child, and constructs a new bond between father and daughter. To put it another way, Zeus averts the danger of a mighty but combative son by producing a daughter equal to him in ability and loyalty. This is the ultimate reason for Zeus' success. ${ }^{55}$

In this new relationship the mother - catalyst of previous usurpations - is excluded. Athena, born without a mother, is deprived of her own potential motherhood her female nature - and will never bear a child. In addition, she has to be a virgin, and we

\footnotetext{
${ }^{53} \mathrm{Cf}$. Solmsen (1949) 67, who writes that the tale of Metis is the vehicle for a profound idea, inasmuch as Metis stands for wisdom.

${ }_{55}^{54}$ Arthur (1983) 99.

55 Of course there are other important reasons for Zeus' success, for example his incorporation of intelligence by swallowing Metis: see Jeanmaire (1956) 18; Clay (1989) 13 and others. Also, Zeus' good
} 
note that she is listed in the Homeric Hymn to Aphrodite as the first of three goddesses whom Aphrodite's power of love cannot affect $(7-8) .{ }^{56}$ Athena's sterility through virginity is vital because it frees Zeus from the cycle of usurpation.

The motherless goddess Athena is more like a man than a woman; or, as Harrison suggested, she is rather a sexless thing, neither man nor woman. ${ }^{57}$ She appears a compeer to Zeus, and shares several qualities with him, including intelligence. The most telling, and curious, correlation is their sharing of the aegis. ${ }^{58}$ The phrase 'aegis-bearing' (aíróxos) is one of Zeus' most common epithets, and the aegis itself is made by Hephaestus for Zeus in the Iliad (15. 309-10). However, Zeus' use of the aegis is mentioned only twice in the Iliad: when he frightens the Achaeans (17. 593-6); and in the reference to its use as foretold on the day of Troy's destruction (4. 166-8).

Yet, in the Chrysippus' fragment cited above (Hes. fr. 343 M.-W.), Metis makes the aegis for Athena:

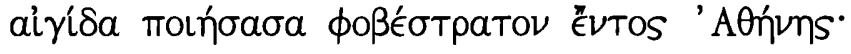

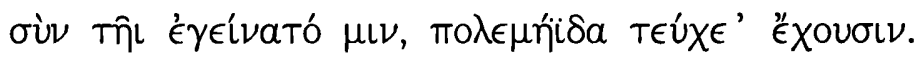

(Hes. Fr. 343 M.-W., vv. 18-9)

she [Metis] who made the host-scaring weapon of Athena. And with it

\footnotetext{
relationship with the gods of the preceding generation: see Caldwell (1989) 181. However, from the thematic point of view, Athena's birth is one of the most important factors in his triumph.

${ }^{56}$ Cf. Chapter VI, Section 2.

${ }_{58}^{57}$ Harrison (1903) 303.

${ }^{58}$ The form and use of the aegis is unclear. It has one hundred golden tassels (Il. 2. 488-9) and is decorated with a Gorgon head (Il. 5. 74-2). Kirk (1985) ad 2. 446-51 comments that, from its etymology, it is probably a goat skin in some form. Fowler (1988) 112 suggests the association of rain-magic, because Zeus produces rain by shaking his aegis (Il. 17. 593-6). Janko (1992) ad 15. 308-11 points out that the word also means 'squall', and, also in its obvious sense, 'goatskin'; in the bards' imagination it is a primitive shield with a shaggy fringe. Gantz (1993) 84 submits that its primary use would not be as something worn for defense, but that, rather, it was held in the hands and shaken to terrify the enemy - as in Il. 15. 229-30, 318-22, Od. 22. 297-8.
} 
(Zeus) gave her birth, arrayed in arms of war.

(Tr. H. Evelyn-White)

The aegis is prepared for Athena even before her birth. In the fragment of the Meropis discussed in Chapter II, the aegis is made by Athena herself from the skin of the Giant Asteros whom she killed in the Gigantomachy. In the Odyssey, there is one reference to the word (22. 297-8): Athena holds up the aegis to terrify the suitors. In the Iliad, Athena wears the aegis to encourage the Achaeans (2.450-2 and 5. 738-42) and to fight with Ares (21. 400-414); she also casts it over Achilles' shoulder (18. 203-4). ${ }^{59}$ Two of these passages, 5.738-42 and 21.400-414, in particular merit our attention for their connection with Zeus.

In the first passage, Athena prepares to join the war, to fight against Ares in order to prevent his support for the Trojans:

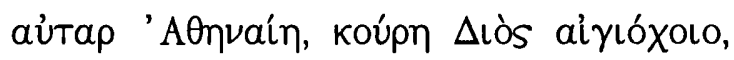

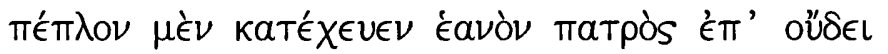

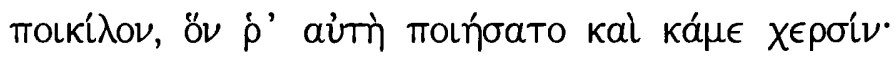

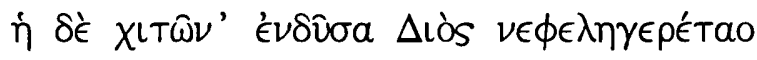

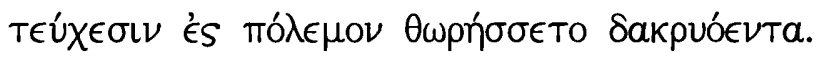

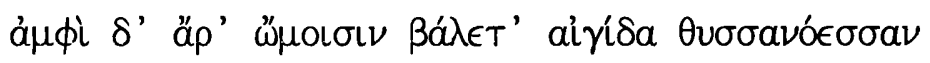

$\delta \in L \nu \eta \dot{\nu}$,

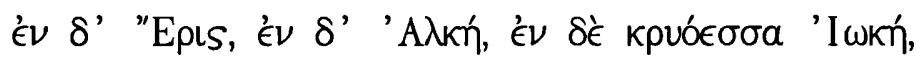

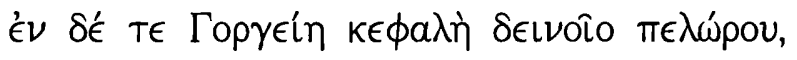

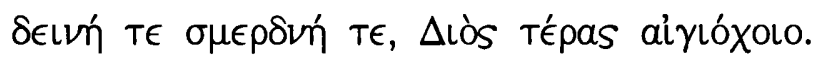

And Athene, daughter of Zeus who holds the aegis, let slip to the floor of her father's house her soft embroidered robe, which she herself had made and worked with her hands. And she put on Zeus the cloud-gatherer's own tunic in its place,

\footnotetext{
${ }^{59}$ Apollo is also associated with the aegis: on Zeus' suggestion Apollo uses it to frighten the Achaeans (15. 229-30, 318-22) and to guard Hector's corpse when Achilles drags him (24. 20).
} 
then dressed in her armour for the misery of war. Round her shoulders she hung the tasselled aegis, a fearful weapon, set with Panic all round it in a circle: and on it there is Strife, and Power, and chilling Rout, and set there too is the head of the fearful monster Gorgon, a thing of fright and terror, a potent sign from Zeus who holds the aegis. (Tr. M. Hammond)

Athena takes off her embroidered robe - a reference which, of course, emphasises the feminine nature of the clothing - and puts on, surprisingly, Zeus' tunic in Zeus' house (734-6). ${ }^{60}$ Then she hangs the aegis round her shoulders (738). It is no coincidence that the phrase $\Delta$ lòs aiylóxolo is used twice in this passage (733 and 742): it effectively signifies that Zeus owns the aegis, and that all of Athena's arms are furnished from Zeus' property. Athena, going out to war, is emphatically identified with Zeus.

In the scene following Athena's arming, Hera asks Zeus' permission to defeat Ares. Zeus answers,

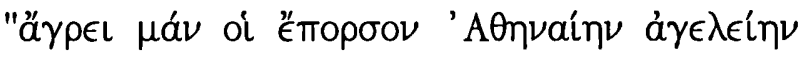

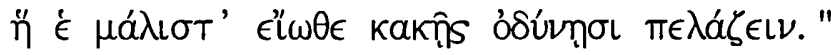

"To your work, then. Set Athene at him, the goddess of spoil - she is the one who most often brings him to inglorious pain. " (Tr. M. Hammond)

As Ares destroys many Greek warriors on the battlefield, this is a good reason for opposing Ares in the context. But as for the subtext, some different features may emerge. In the light of the importance given to the motif of generational strife, it is significant that Athena's target is Ares, the son of Zeus and Hera, and, as such, a potential candidate for

\footnotetext{
${ }^{60}$ Kirk (1990) ad 5. 734-7 notes that this passage accords with $1 l .8 .374-6$ where Athena enters Zeus' house to arm for war. Ch. Chapter III, Section 1, n. 8.
} 
the role of father-usurper. In the Iliad, Zeus' supremacy looks secure, but the motif of the threat of a son seems present in this passage; it gives Zeus reason to dislike Ares. Zeus might be expected to be wary of his sons lest he should experience the same calamity as Uranus and Cronus, even after he attained the sovereignty. Ares is not actually challenging the power of Zeus, but his insubordinate role in the liad seems to reflect the motif of potential father-usurper as a subtext. In this context, it is understandable that Zeus consents to Ares' defeat at Athena's hands. ${ }^{61}$ The symbolism is profound: it is as if Zeus himself defeats Ares when he sends forth Athena - born from Zeus, armed by Zeus, dressed in Zeus' tunic, and equipped with Zeus' aegis.

At 21.400-414, Athena, wearing the aegis, fights Ares:

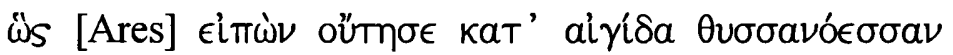

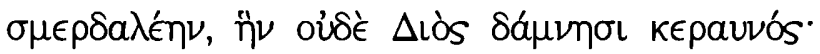

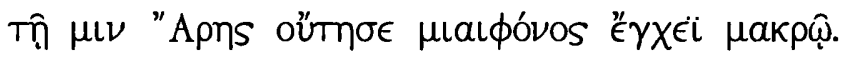

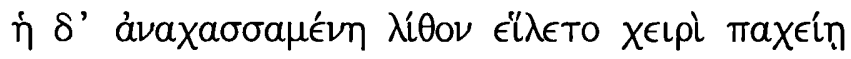

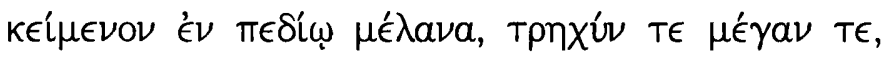

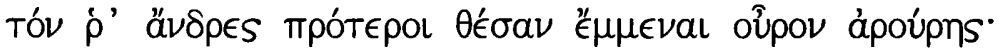

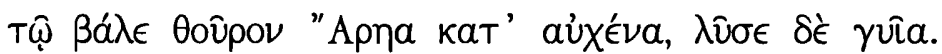

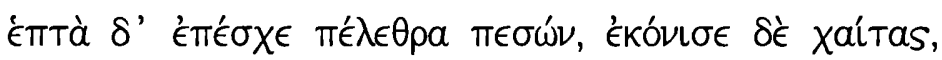

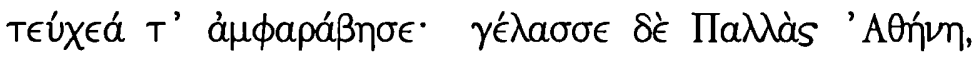

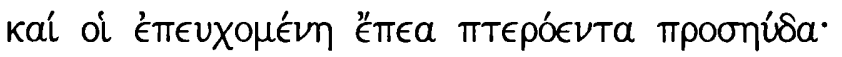

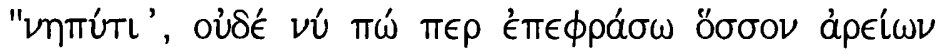

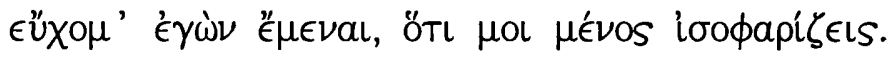

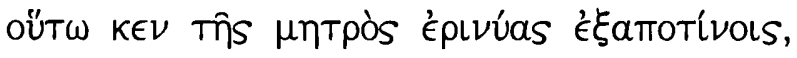

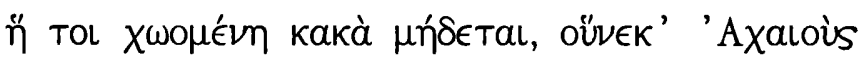

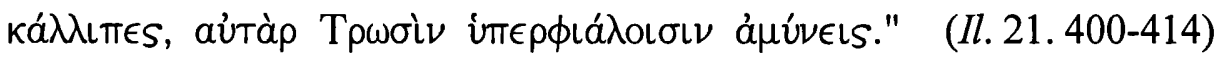

\footnotetext{
${ }^{61}$ Athena also restrains Ares when he intends to join the war against Zeus' will (Il. 15. 119-41).
} 
So speaking he thrust at the tasselled aegis, that fearful thing which not even Zeus' thunderbolt can break: and Ares the murderer struck there with his long spear. Athene stepped back and picked up in her massive hand a stone that was lying on the plain, a black stone, huge and jagged, which men of an earlier time had set there to mark the boundary of a field. With this she hit furious Ares on the neck, and collapsed his strength. He covered seven acres where he fell, and sullied his hair in the dust, and his armour clattered about him. Pallas Athene laughed and spoke winged words in triumph over him: 'You poor fool, you cannot have thought at all how much greater strength I can claim than you, if you try to match your power against me. So this can be payment for your mother's curses - she is angry and wishes you ill, because you have deserted the Achaians and give your help to the proud Trojans. '

(Tr. M. Hammond)

Even Zeus' thunderbolt cannot break the aegis (401): this indicates its extraordinary power, since Zeus' thunderbolt is his ultimate weapon, used to destroy his most dreadful enemy, Typhoeus (Theog. 853-8). Ares tries to strikes at the aegis with his long spear (Il. 21. 402): this could be interpreted as symbolising Ares' challenge to Zeus, even though it is worn by Athena at that moment. If Ares succeeded in piercing the aegis, he could overwhelm even Zeus' thunderbolt, and could conquer the defenceless Zeus.

However, Ares' challenge is quite easily beaten off by Athena, and we note her words after she strikes him with a large, rough black stone (404): ${ }^{62}$ you have not yet recognised how much stronger I am' (410-11). The triumphant claim reminds us, again, of the theme of (inter-)generational strife, as Athena reiterates - backed up by Zeus' aegis that the son cannot defeat his father.

Zeus' strategy is to 'divide and rule'. By giving birth to Athena, he acquires a counterpart who fights on his side and as his deputy, defeating his son who might prove a

\footnotetext{
${ }^{62}$ Richardson (1993) ad loc. notes the resemblance of this passage with 7. 264-5, where Hector hits Ajax with a similar stone. Kirk (1990) ad 7. 264-5 suggests that the stone might be meteoritic, because of its
} 
challenger to his power. When Athena claims her victory, she laughs ( $\gamma \in \dot{\epsilon} \lambda a \sigma \sigma \epsilon, 408)$; only nineteen verses earlier, Zeus, too, laughed with joy ('́\}'㇒́ $\lambda a \sigma \sigma \epsilon, 389)$ to see the gods joined, separately, in conflict, while he maintained his supremacy. This reminds us of Zeus' laughter in delight at the appearance of Athena in the Homeric Hymn to Athena

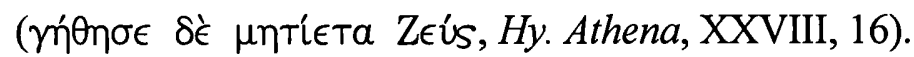

It is a marker of Athena's functional affinity to Zeus that, as Zeus becomes more remote from human beings, she eventually replaces him as the chief guardian of the state and people. ${ }^{63}$ In the Iliad, Zeus cares for particular mortals (for example, Sarpedon: 16.

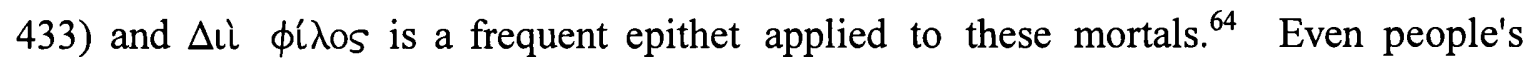

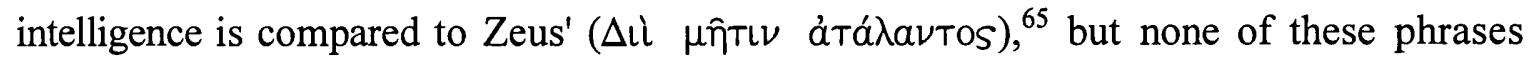
appear in the Odyssey - instead, Athena becomes the dominant figure.

When Athena emerges from the head of Zeus in the Theogony, she is purely a warrior and guardian of the state:

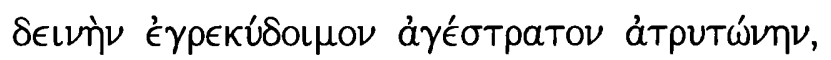

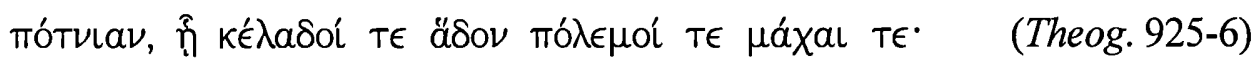

the fearsome rouser of the fray, leader of armies, the lady Atrytone, whose pleasure is in war and the clamour of battle (Tr. M.L. West)

colour and shape. Such stones, which may have been what were later understood to be meteorites, might have been thought of as thunderbolts. See Chapter II, n. 27 on äk $\mu \omega \nu$, and also Janko (1992) ad 15.18-31. ${ }^{63}$ Pope (1960) 125 notes that Zeus becomes far more impartial, dignified and remote, just as his dwellingplace on Olympus is no longer regarded as an earthly mountain.

${ }^{64}$ Achilles: five times $(1.74 ; 16.169 ; 18.203 ; 22.216 ; 24.472)$; Hector: four times $(6.318 ; 10.49 ; 13.674)$; Odysseus: three times $(10.527 ; 11.419 ; 11.473)$; once for Phuleus $(2.628)$, Phoenix $(9.168)$ and Patroclus $(11.610)$.

${ }^{65}$ Odysseus: thrice $(2.169 ; 2.407 ; 2.636)$; Hector: twice $(7.47=11.200)$. 
There is no mention of her patronage of craftsmanship. She is a new leader, but will not displace her father; rather, she will carry out his will as his deputy. In the Iliad, Athena is expected to participate in war (5.430), which contrasts with Aphrodite's stated domains of marriage and love. At 6.492, war is said to be man's concern:

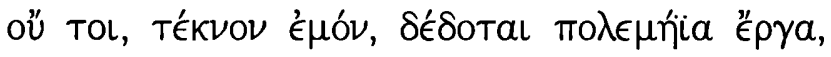

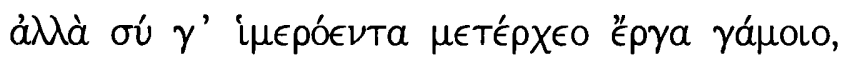

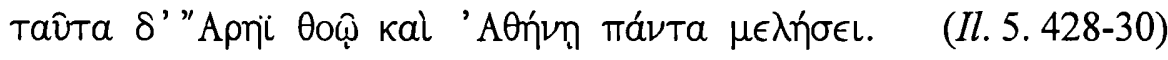

War's work, my child, is not your province. No, you busy yourself with marriage and the work of love, while all this will be for quick Ares and Athene to see to. (Tr. M. Hammond)

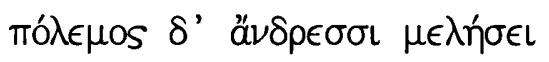

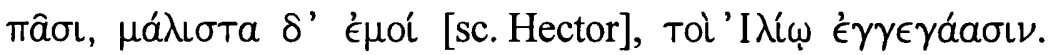
(Il. 6. 492-3)

War will be the men's concern, all the men whose homeland is Ilios, and mine above all. (Tr. M. Hammond)

These passages imply that the goddess Athena functions like a male god. A deity could do everything, but in the case of Athena, the boundary between male and female remains ambiguous. The creation of such a deity, a weaker doublet of Zeus himself, is the ultimate resolution to the internecine conflict, and it is in this creation that we view the culmination of Hesiod's logic. The inevitable replacement of father by son - elder generation by younger - is by-passed with the creation of this co-operative daughter. 
Athena is the symbolic representation of the rule of Zeus; as Brown comments, she is the symbol of a new kind of state, or of the cultural renewal of Zeus' world. ${ }^{66}$

In classical times, Athena becomes a champion of human skill and intelligence. ${ }^{67}$ In Plato's discussion of Athenian education, boys and girls are encouraged to imitate Athena (Leges 796c). ${ }^{68}$ Athena is 'the incarnation of their life and being', ${ }^{69}$ and she constantly works 'to redress the balance of power between Olympus and the human race' $^{70}$ The relation between Zeus and Athena is intensified; thus in Aeschylus' Eumenides, Athena says

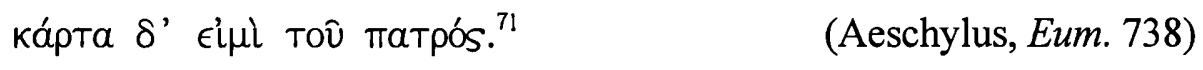

Athena knows the will of Zeus, and effects it as he wishes. ${ }^{72}$

In both Homer and Hesiod Athena is a daughter of Zeus, younger and subordinate. However, it is generally acknowledged that Athena had a long history of her own, probably as a pre-Greek goddess. ${ }^{73}$ Pausanias reports a tale of Athena's origin which differs from that of Homer and Hesiod: she is the daughter of Poseidon and Lake Tritonis (1.14.6). ${ }^{74}$ We note Campbell's point that, at the earliest stages of Greek civilisation,

\footnotetext{
${ }_{67}^{66}$ Brown (1952) 135.

${ }^{67}$ Jeanmaire (1956) 30-3 illustrates the genealogy of the royal family of Athens, which is strongly connected with professional craftsmen.

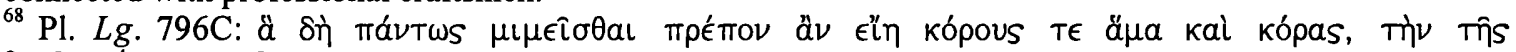

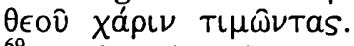

${ }^{69}$ Harrison (1903) 302.

${ }^{70}$ Shearer (1966) 16.

${ }^{71}$ Sommerstein (1989) ad loc. offers three possible interpretations: (a) 'I am wholly my father's child; (b) 'I am wholly on the side of the father'; (c) 'I am a faithful follower of my father'.

${ }^{72}$ Neils (2001) 229-31 discusses the vase paintings and the relief on the Parthenon which represent Athena and Zeus side by side in similar poses.

${ }^{73}$ Cook (1940) 3.189 suggests that Athena might be a snake-goddess of the early Cretans and - in 3. 7489 - the pre-Greek mountain mother. He discusses (3. 201-3) the presentation of Hephaestus and Athena as husband and wife in prehistoric times - local equivalents of Cronus and Rhea.

${ }^{74}$ The epithet Tritogeneia may indicate the existence of an old tradition of the birth of Athena from the sea, like the miraculous birth of Aphrodite. See Brown (1952) 143.
} 
'wherever the Greeks came, in every valley, every isle and every cave, there was a local manifestation of the mother-goddess of the world whom Zeus, as the great god of the patriarchal order, had to master in a patriarchal way. ${ }^{.75}$ The story of Athena's motherless birth from Zeus' head is a product of this context.

Through marriage Zeus overcomes and integrates the problems posed by many of these goddesses. ${ }^{76}$ Athena alone, however, is chosen to be his daughter, perhaps because she is too strong and dangerous to be a wife. By making Athena a maiden daughter, he not only succeeds in removing the threat of a potentially powerful son as challenger, but also establishes a new, protective and preventative relationship between father and daughter. Uranus and Cronus were doomed by the cyclic predictability of the father-toson relationship; Zeus, however, ensures his survival by transforming the relationship into one of father-to-daughter.

A daughter, however strong, will never usurp her father. For the ancient Greeks,

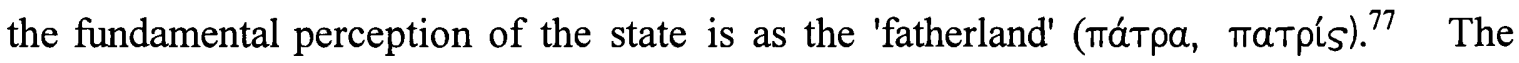
state is a family and the image of the ruler is one of a 'father'. Such ideology leaves no place for the daughter as sovereign heir; the daughter cannot be a threat. ${ }^{78}$ In Hesiod, Zeus' innovation is to construct a new relationship which will not displace him. ${ }^{79}$ The creation of a new type of deity - feminine akin to masculine - is the greatest factor

\footnotetext{
${ }^{75}$ Campbell (1964) 149.

${ }^{76}$ Slatkin (1968) 129 points out that Zeus' marital dominance is his major achievement. Cf. Thalmann (1984) 40, who writes that the marriages and children of Zeus characterise his rule.

${ }^{77}$ Stevenson (1992) 429. He explains the typically political relationship among the Greeks (and Romans) as that of benefactor-beneficiary.

${ }^{78}$ As Arthur (1983) 64 suggests, achieving the patriarchal form of the family is the teleological goal of the Theogony.
} 
actuating Zeus' success. The concept of a strong alliance between Zeus and Athena fits perfectly both with Panhellenic ideals and Greek societal and moral norms, ${ }^{80}$ thus ensuring the continued popularity and success of Homer and Hesiod.

${ }^{79}$ In Sophocles' O.T. and O.C., blind Oedipus is led by his daughter Antigone. This also seems to show that the ancient Greeks found their solution and consolation for the conflict between father (Laius) and son (Oedipus) in the relation between father and daughter.

${ }^{80}$ Brown (1952) 138 links the creation of the myth of the birth of Athena particularly with the Panathenaic festival in 566/5 B.C., but this date seems to be too late. 


\section{Chapter V : Typhon, the Son of Hera}

The composition and unity of the Hymn to Apollo are controversial problems. Since David Ruhnken suggested that the Hymn to Apollo consists of two originally independent poems, most scholars have divided the hymn into a 'Delian' and a 'Pythian' part.' Recent scholarly work, however, tends to harmonise the differing views, admitting, on the one hand, the separate authorship of the Delian and Pythian sections, but recognising, on the other hand, a certain unity between the two. ${ }^{2}$

I align myself with these recent scholars: although differences in outlook, style, language and metrical technique cannot be ignored, I contend that the combination is not accidental. I do not, however, take the purely Unitarian view of Penglase, who writes that 'the unity of construction by one poet seems to be the only reasonable conclusion'. ${ }^{3}$ Rather, as many scholars point out, the differences between the two parts are readily observable. Nevertheless, they are also connected by many similarities, and the whole poem seems to have a coherent design. The comic poet Aristophanes probably knew the hymn as a unity, since he seems to

\footnotetext{
${ }^{1}$ Many German critics have argued the separatist view. The earlier history of criticism of the hymn is in Drerup (1937) 81-99; a thorough account of the views on this problem is in Förstel (1979) 2059.

${ }^{2}$ For example, West (1975) 161-5 argues that the poets of D. and P. are different, because of their different geographical outlook and stylistic differences, such as neglect of initial digamma, but that there is a "conspicuous parallelism" between their opening sections. According to Janko (1982) 103104, dividing the hymn at line 178 commands general acknowledgement, because lines 177-8 are a normal conclusion to a complete hymn, and the geographical outlook and religious interests of the two sections differ profoundly; however, the two parts of the hymn came to be coupled together by Kynaithos who was responsible for the epic performance at Polykrates' grand Delian and Pythian festival. In his review of Clay in $C R 41$ (1991) 12-3, he adopts a more unitarian position. Sowa (1984) 173 and 183 admits religious, linguistic and formulaic differences, but from the point of view of thematic analysis: that is, the poem presents a continuous unity. Burkert (1979) 61 notes that the Delian-Pythian festival of Polycrates at Delos in 522 B.C. presented an appropriate situation for a combined Delian-Pythian hymn to Apollo, and suggests that a Homerid from Chios in fact composed or arranged the text.

3 Penglase (1994) 117, following Miller (1986) xi.
} 
quote from both the Delian and the Pythian parts. ${ }^{4}$ With this rationale in mind, I shall treat the text that we have before us as one composition.

The digression of the Typhon episode (305-355) has often been regarded as an interpolation. Some even hold that the hymn has been pieced together from three different sources: the Delian, Pythian and Typhon episodes. ${ }^{5}$ The main reason for regarding the Typhon episode as an interpolation is that its connection to the main narrative seems awkwardly contrived. ${ }^{6}$ However, the details of connection are worth investigating more closely: how does the linkage - if any - work? I suggest that there is a design in the arrangement of the motifs, and that this design contributes logically to the structural and thematic effectiveness and persuasiveness of this digression. It is the aim of this chapter, therefore, to examine the details of the digression and, from this examination, to elucidate the logical connection between the digression and the narrative as a whole. One significant consequence of my analysis is the demonstration that increased emphasis ought to be placed on the issue of cosmic strife - in this case, between Typhon and Zeus, and, also, between Apollo and Zeus - as an important constructional motif in the hymn.

\section{The dragon}

I now turn to the episode of the dragon, essential because it functions as the

\footnotetext{
${ }^{4}$ Allen \& Sikes (1904) 82 and 113 note that line 114 is perhaps echoed at $A v .575$, and line 443 at Eq. 1016.

${ }^{5}$ For arguments re interpolation see Allen \& Sikes (1904) 65; cf. Clay (1989) 64.

${ }^{6}$ For example, Janko (1982) 116 describes it as 'clumsy'.
} 
framework of the digression. With his strong arrow, Apollo kills the female dragon who lives by the fair-flowing spring (300-301). The digression of the Typhon episode begins five lines after the killing of this dragon. Both the story of the dragon and the digression begin very abruptly (300ff.). At line 282, Apollo comes to Krisa and peacefully builds his temple there (285-289). Apollo speaks to Krisa with the same words that he employed towards Telphousa $(247-253=287-293)$, but the narrative then differs sharply: no objection is raised, nor is there any mention of the existence either of the dragon or of anything that might become an obstacle to his building a temple. Then, immediately, the killing of the female dragon is narrated. The only word linking Krisa and the dragon is à $\gamma \chi 0 \hat{v}$ (300); the location of the dragon is 'near' the 'fair-flowing stream', with which Krisa herself is identified. There are no sinister words from the dragon, nor any direct speech between Apollo and the dragon; unexpectedly, the first mention of the dragon is its killing. In the next three

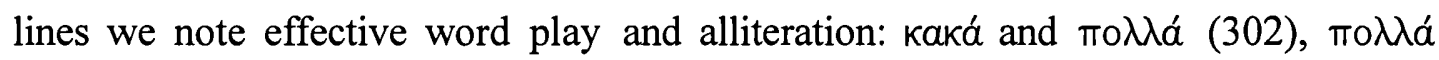

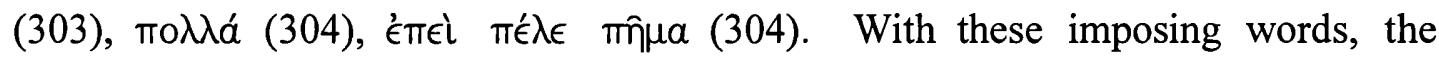
character of the dragon is emphatically expressed: notably, they can also be interpreted as providing Apollo with a motive for slaying her.

The epithet which introduces Apollo in this episode should also be noted: he is called ävak $\Delta$ iòs viòs (301) - the lord the son of Zeus. It is crucial that the relationship between Apollo and Zeus is emphasised at this point. Not only in the digression, but also throughout the entire hymn, Apollo's strong kinship with Zeus is the leitmotif which pervades and 'colours' the action and the narrative. 


\section{The Arrangement of the motifs of the dragon and Typhon}

The episode which tells the story of Hera's generation of Typhon is introduced as abruptly as that of the killing of the dragon. The phrase кai потє starts the digression, and in this unexpected way 'the past intrudes into the present'. ${ }^{7}$ In the parallel created between the dragon and Typhon, it is curious that only the birth of Typhon and the death of the dragon are narrated. I suggest that there was some reason advantageous to the composer for this complicated arrangement, and some special motive for omitting mention (a) of a detailed account of the dragon, and (b) of the death of Typhon. In order to trace the design of the digression, let me begin by postulating why there is no detailed account of the dragon.

Had the story of the dragon's birth been part of the narrative, we might expect it to have mentioned the place that she occupied: however, this would then imply that oracles had been given there before the advent of Apollo. Certainly, there are other versions of the myth in which either Themis or Gaia give oracles, and the dragon is the protector of that place. ${ }^{8}$ However, the hymn declares that Apollo's oracle is a new foundation: this, therefore, would strongly resist any notion of his having a predecessor. The defeat of the monster would obviously signify the usurpation of the ancient shrine by a new god, yet the narrative is carefully designed

\footnotetext{
${ }^{7}$ Austin (1966) 303 remarks that 'a past occurrence is used not merely as an edifying example but as positive proof of a present possibility.'

${ }^{8}$ For example, Aeschylus Eum. 1-8 (the transfer of the oracle's ownership from Gaia to Themis to Phoibe to Apollo); Euripides I.T. 234-1282 (Themis protected by the dragon). Sommerstein (1989) ad A. Eum. 1-2 comments that the first oracular deity at Delphi is Gaia. Cf. Chapter IV, n. 21.
} 
to avoid any mention of this. ${ }^{9}$ That is, the poet's strategy is to conceal any detailed account of the dragon, in order to stress that Apollo's first oracular installation was without precedent.

Folk-etymology suggests another reason why any detailed account of the dragon is suppressed. Although Simonides, quoted in a letter of the Emperor Julian, gives the name of the dragon as Python (fr. 573 Page; Jul. Ep. 24. 395D), this is not mentioned in the hymn. ${ }^{10}$ Had a detailed account of the dragon been offered, one might reasonably expect it to have been named. Therefore, the names of both the dragon and the location must be carefully concealed before it is killed, since the hymn

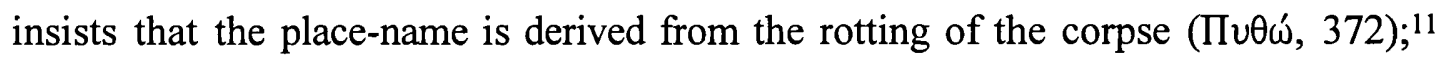
logically, the location could not have a name before Apollo came, because it was uninhabited. When the account of Apollo's advent is narrated, the place is very carefully called 'Krisa, under snowy Parnassus' (269), suggesting the poet's attempt to avoid calling it Delphi or Pytho. For encomiastic purposes, it is of great importance that Apollo should found his oracular temple in a place previously unoccupied. It is this special concern for etymology and for the sacred identification of the place with Apollo which provides us with a second reason - namely, the aetiological design of this hymn - why the dragon is unnamed and its birth and life

\footnotetext{
${ }^{9}$ Sourvinou-Inwood (1991) 231 remarks that this is the model of a violent take-over leading to a higher order. Clay (1989) 62 also points out that 'by ignoring Delphic tradition and denying any continuity or connection between Apollo's establishment and a prior prophetic seat on the same spot, the hymn proclaims Apollo's oracle to be a uniquely Olympian institution and an essential component of the Olympian dispensation.' Conversely, Alkaios' Hymn to Apollo presents Apollo as the first owner of the Delphic oracle. Paus. 10. 5. 6-8 gives both versions.

${ }^{10}$ The composer of this hymn must have had knowledge of the name of the dragon, considering his

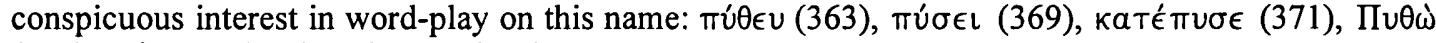

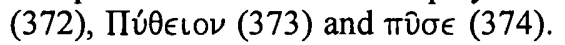

11 'The rotting' indicates the attribute of Apollo as the 'sun god', since it is narrated in 374 that 'at

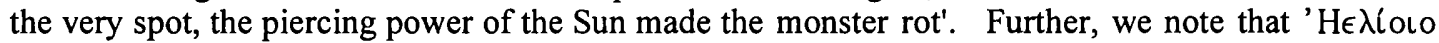
is emphatically placed as the final word in the closing line. Miller (1986) 89 remarks that 'rotting'
} 
remain untold. ${ }^{12}$

A third reason why the dragon's story is curtailed is to afford a connection with Typhon. One of the few bits of information given about the dragon in this hymn is that it is female. This differs from other versions, where the dragon is male. ${ }^{13}$ This one detail has a special significance: being female, the dragon is able to become nurse to Typhon. According to the text (354), it is the only factor which connects the dragon with Typhon. Since few particulars of the dragon are given, and her other attributes remain mysterious, the revelation of her gender becomes all the more pointed and deliberate.

\section{Typhon}

The treatment of Typhon in this hymn is unique. He is introduced in connection with the dragon, yet he is not the central figure of the digression. Only his birth is narrated: there is no mention of his appearance, his fight with Zeus, or his death. The parallel between Typhon and the female dragon is clear: Typhon is $\pi \hat{\eta} \mu a$

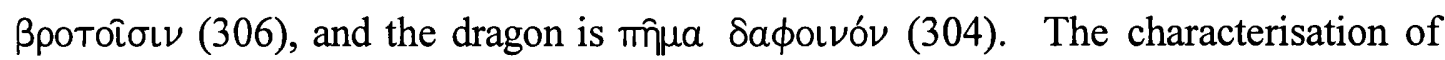
the monsters at the start of the digression is echoed by the same words in line 354 :

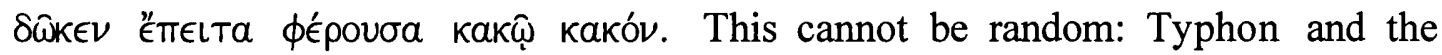

means that the victim's body is not buried but left on the spot to be devoured by birds and dogs, a typical threat in heroic contests.

12 The claim that Thebes was uninhabited when Apollo was journeying to his oracular place (226) is made for the same encomiastic reason.

13 Further to this, being female, the dragon must be unnamed, since Python - if the composer knew that name - is a male name. Fontenrose (1959) 13-21 gives five versions of the myth of Apollo's combat with a dragon, among which only the version elaborated in this hymn features a female dragon. (The female dragon is called Delphyne by later writers, which seems to be a variant of 
dragon are thus consciously paralleled as 'kindred spirits'. ${ }^{14}$

The poet's deliberate choice of these two episodes - the female dragon as Apollo's opponent, and the Typhon episode as a digression - is significant, since, in myth, the dragon is not the only enemy whom Apollo fought. Indeed scholars have suggested that the dragon and Typhon are variants of the same monster in combat myth; moreover, the names Typhon and Python are possibly variants of a single name. $^{15}$

The only reference to Typhon in the Iliad occurs in the explanation of earthquakes:

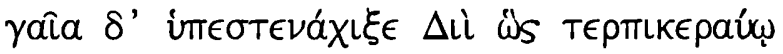

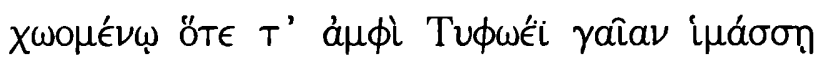

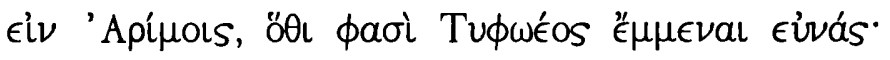

The earth groaned under them as it does under the anger of Zeus who delights in thunder, when he lashes the ground over Typhoeus, in Arima, which they say is the place where Typhoeus lies.

(Tr. M. Hammond)

The myth of Typhon who lives underground at (or among the) Arimoi was already known, ${ }^{16}$ but a detailed account of the fight between Zeus and Typhon is

Telphousa. See ibid., 14, n. 4). The version featuring the male dragon predominates: for example, Euripides I.T. 1245, Apollodoros 1.39, and Pausanias 10.65.

14 Miller (1986) 84.

15 Fontenrose (1959) 91 defines the process of change: dental - vowel - labial to labial - vowel dental, with the initial consonant becoming unaspirated, the final remaining aspirated, i.e., TY $\Phi$ $\Pi \Upsilon \Theta$. Although this interchange cannot be fully attested, Buck (1933) 129 gives the example of the word group, $\theta \epsilon \hat{f} \nu \omega-\epsilon \in \pi \epsilon \nu \circ \nu$, and remarks that the Greeks were unconscious of the actual relation

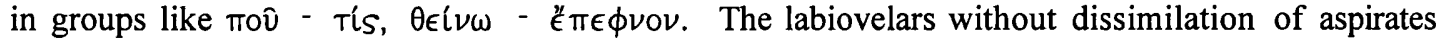
would have been *ghwughw-. Sihler (1995) 162-3 gives several examples demonstrating that *gw becomes both $t$ and $p$ : this change may partly explain how the two names, Typhon and Python, come from the same root. Cf. also Beekes (1995) 128.

${ }^{16}$ Even in antiquity, there was uncertainty whether Arimoi referred to a tribe or a place. Pindar $P y$. 1.15 places Typhon under Mt. Etna. Kirk (1985) ad loc. suggests various locations; according to 
suppressed in the Iliad. However, the details - the thunderbolt and the anger of

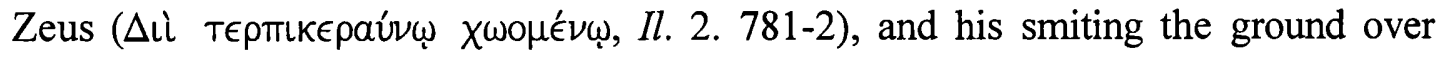

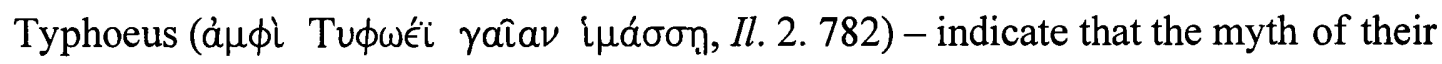
combat was known to the composer.

The Theogony (820-868) gives the detailed story: Typhon is the last threat to Zeus' power. ${ }^{17}$ The Hesiodic account of Typhon's attributes (character and appearance) and power is precise and detailed. The fight with Zeus is vividly described: the land, sea, heaven, rivers, and even the underground regions are affected. These details emphasise both Typhon's awesome strength and the superior might of Zeus who must destroy him. On the other hand, in the hymn, all these stories are suppressed, although the composer seems to be well-acquainted with the Hesiodic version. ${ }^{18}$ The only references to Typhon's character is that he is not like humans or gods (351), and that he is baneful to humans (352). This is a remarkably compact version of his 'history'.

Interestingly, similar depictions are ascribed (a) to Echidna in the Theogony (295-6), who resembles neither gods nor men, and (b) to the Nemean Lion who is baneful to humans (329). These two monsters are closely related to Typhon in the Hesiodic genealogy: Echidna is the wife of Typhon, and the Nemean Lion is his grandson. Moreover, the Nemean Lion is reared by Hera (328) and killed by Herakles, the son of Zeus (332).

Strabo 13. 626: near Sardis, in Mysia, in Cilicia, Syria, Mt. Etna, or in Pithekoussai. On Arimoi see West (1966) 250.

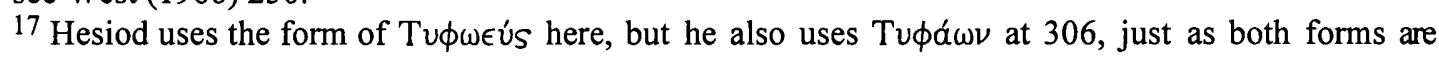

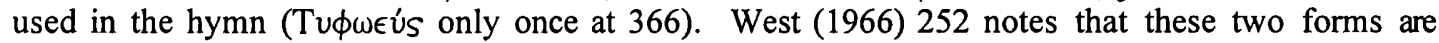

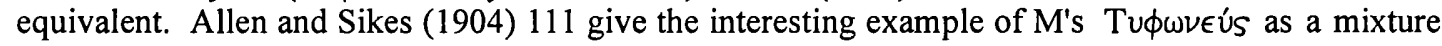

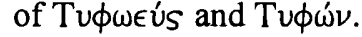

18 Janko (1982) 119; Clay (1989) 66; O’Brien (1993) 16. 
In the Theogony is another monster who has strong links with the hymnic Typhon: the serpentine Hydra of Lerna, who is the daughter of Typhon. She is reared by Hera out of malice towards Herakles (314-5) and subsequently destroyed by him (316):

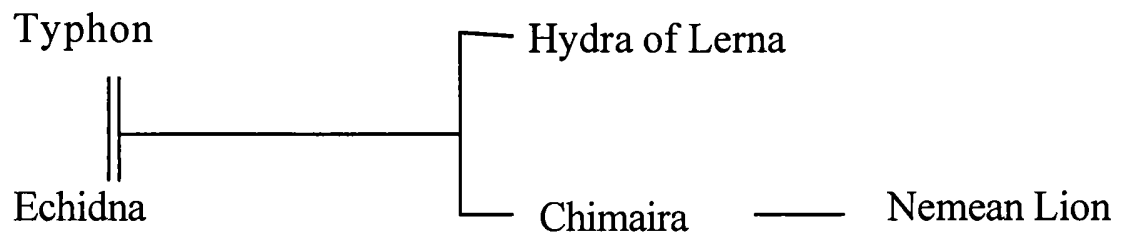

Our Hymnic Typhon is closely connected with that in Hesiodic genealogy; all of his family members except the Chimaira either have a similar nature to the Hymnic Typhon or show Hera's strong influence. Thus the description of Typhon in the hymn reminds us of the many other monsters antagonistic towards Zeus in the Hesiodic version. Thus the shadow of Hera's rivalry with Zeus is never far in the background.

The most significant reason for the omission of Typhon's full history is that he is not, in fact, treated as the main figure of the digression. The second reason is thematic: this is a hymn to Apollo, not to Zeus, and therefore the encomiastic purpose of the hymn would be distorted and weakened if full details of Typhon and his fight with Zeus were given. ${ }^{19}$ A third reason is that the hymn presupposes the audience's knowledge of the Typhon myth, so it could be summarised quite briefly.

At the start of the digression, the identity of the central figure is ambiguous -in the first line (305), Hera is mentioned but, in the second line, so is Typhon:

\footnotetext{
${ }^{19}$ Miller (1986) 87-8.
} 


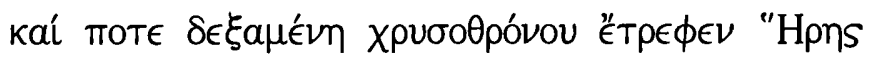

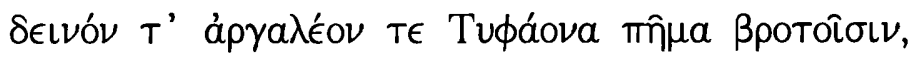

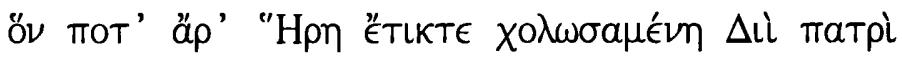

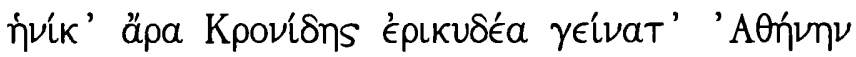

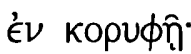

(Hy. Apollo 305-9)

And once from golden-throned Hera she received and reared

Dreadful and baneful Typhaon, a scourge to mortals.

Hera once bore him in anger at father Zeus,

When indeed Kronides gave birth to glorious Athena

From his head; (Tr. A. Athanassakis)

One might think that the central figure in the digression will be Typhon, given the connection with the dragon, and given that Typhon's birth is narrated immediately (307-8). However, it is noticeable that the emphasis gradually begins shifting to Hera, and when her speech starts (311), it becomes clear that it is she who plays the most important role in the digression. ${ }^{20}$ In the Theogony, Typhon's death, and not his birth, is narrated in detail, because it emphasises Zeus' victory over Typhon: here the hymn narrates only Typhon's birth in order to focus on Hera who gave birth to him.

Instead of the myth of combat with Zeus, the hymn illustrates a different aspect of Typhon which can be paralleled with Hephaestus (316-21). Differing from the Hesiodic version, Hephaestus here is the son of Zeus and Hera. ${ }^{21}$ Hera's anger at Hephaestus' deformity, coupled with her rage at the birth of Athena, brings

\footnotetext{
20 This shifting of emphasis may be characteristic of this hymn: similar examples are observed by Clay (1989) 33 who notes the geographical catalogue of Leto's journey when Hera prevents Apollo's birth (30-49) as 'the instance of the peculiar gliding transitions favoured by the poet'.

21 öv Tékov aủTì (317) is ambiguous. Following Allen \& Sikes (1904) 106, Miller (1986) 85, and Clay (1989) 68, I understand this to be 'my very own son'. In Theog. 927, Hera is his sole parent. Concerning Hephaestus' parentage, this hymn adopts the Homeric account (Iliad 14.338, Od. 8.312).
} 
about her creation of Typhon.22 The similarity of Hephaestus to Typhon is conspicuous: both are not the favourites of their mother ${ }^{23}$, Hera, and both are protected by nurses (Hephaestus by Thetis, and Typhon by the dragon). In addition, I propose another parallel: their imminent doom. The Iliad gives two versions of the fall of Hephaestus: at 1.590 he is thrown from heaven by Zeus; at 18. 395 this is carried out by Hera - this latter version being followed in the hymn. The former version, however, indicates that there existed a myth concerning Hephaestus' insubordination against Zeus and his subsequent punishment. ${ }^{24}$ Thus, both Typhon and Hephaestus share the same function as challengers of Zeus' power. The coincidence cannot be accidental: in this context, the mere mentioning of their names together is significant, although the threat to Zeus is never fully delineated.

\section{Hera}

Hera's major function in the digression is suggested by the mention of her name in the first line (305). The composer's preference for the version in which Hera is the mother of Typhon is relevant. In the Theogony, Typhon is a son of Gaia and Tartaros (821-822); but in this presentation of the myth, Hera becomes the central figure in the Typhon episode, and her speech constitutes the main part of the digression.

An elaborate example of the technique of ring-composition is observed in the hymn:

\footnotetext{
22 Janko (1992) 199.

${ }^{23}$ Hephaestus is disliked by Hera and thrown down by her (Il. 18. 395; Hy. Apol. 318), and for Typhon's case, see note 32 below.
} 


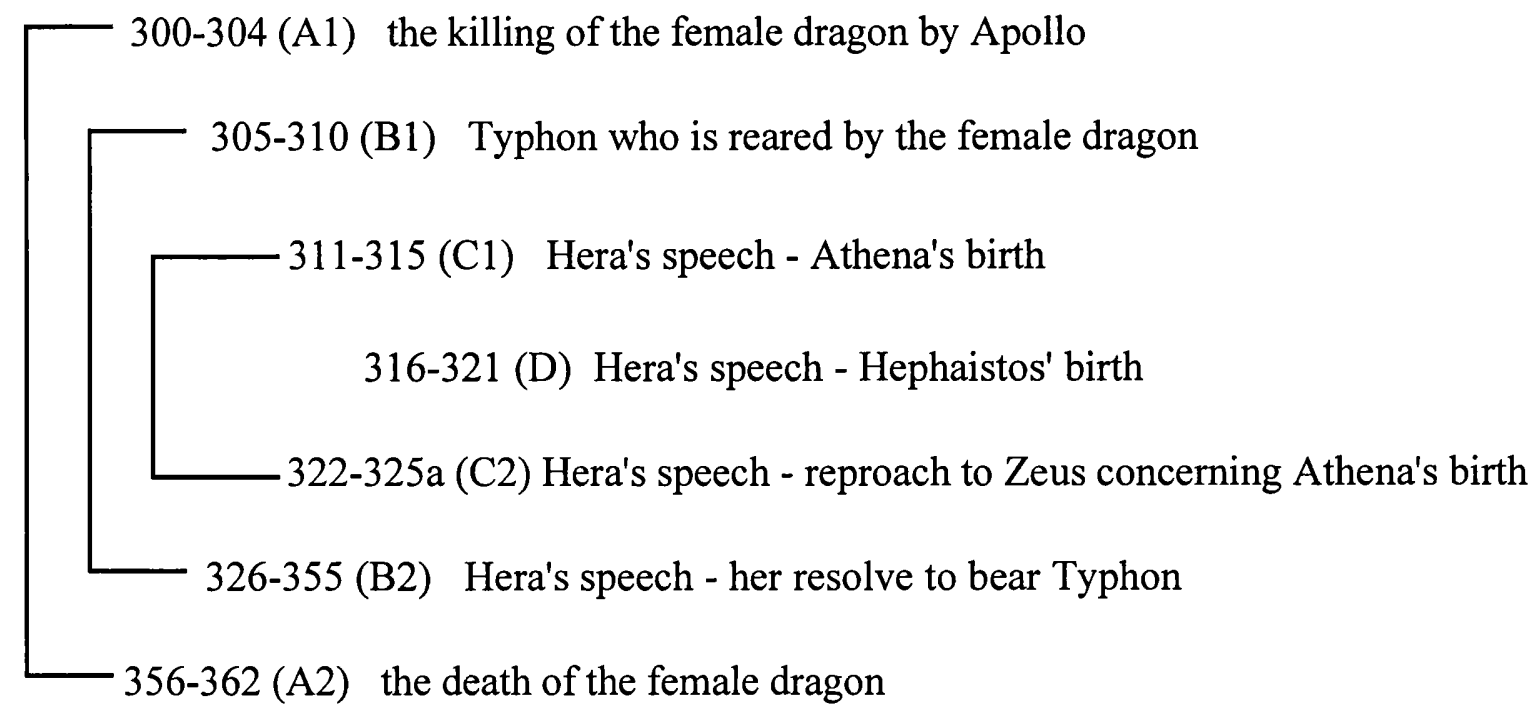

The earlier part of the Typhon story (B1), that of the nurse-baby relationship, functions as the link between the female dragon and Typhon; the latter part (B2) narrates the detailed story of Typhon's birth. The birth is contrived by Hera as a challenge to Zeus, while Athena's birth is Zeus' contrivance to secure his own power in Olympus. In this neatly structured composition, Hephaestus' birth is, literally and metaphorically, surrounded by contrivances and by challenges between Zeus and Hera. This arrangement, with his birth in the center of the ring, ${ }^{25}$ emphasises the significance of Hephaestus' birth as a challenge to Zeus. In other words, the detailed story of Typhon's birth, on the one hand, reveals Hera's contrivance against Zeus, and, on the other, vividly contributes to the background of rivalry that underlies the episode of Hephaestus' birth.

A similarly grounded motif at the heart of this ring composition is Hera's

24 O'Brien (1993) 101-2. Cf. Chapter II, Section 3, esp. n. 60. For a discussion on rebellion and challenge, see Introduction.

${ }^{25}$ Stanley (1993) 8 points out that emphasis falls on the central element in the ring-composition. For the significance of this central element, see also Lohmann (1970) 25. 
abrupt lament for Thetis' actions: this lacks preliminaries or any detailed explanation ${ }^{26}$ :

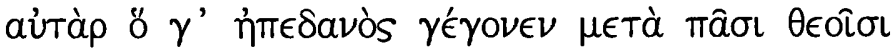

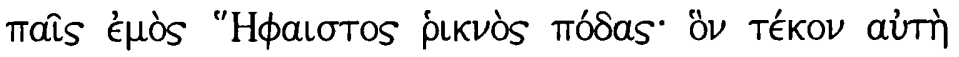

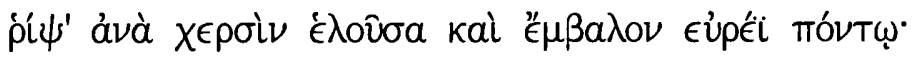

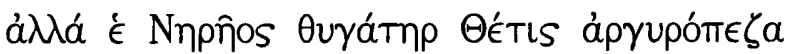

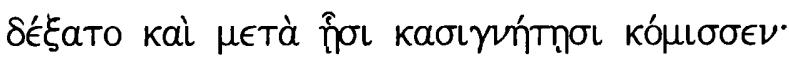

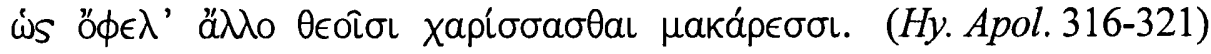

But my son, Hephastus, whom I myself bore

has grown to be weak-legged and lame among the blessed gods.

I took him with my own hands and cast him into the broad sea.

But Thetis, the silver-footed daughter of Nereus, received him and with her sisters took him in her care.

I wish she had done the blessed gods some other favour!

(Tr. A. Athanassakis)

What does Hera means by saying that 'I wish she had done the blessed gods some

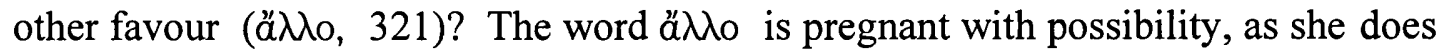
not specify her meaning. I contend that it refers to Thetis' power to beget a child mightier than his father. ${ }^{27}$ That is, Hera is referring to Thetis' potentiality: she regrets that Thetis has not realised this, thus missing a rare chance to usurp Zeus' throne. Since Hera's own son, Hephaestus, is incapable of challenging the power of Zeus, Hera would wish for a mighty child, even one born of Thetis. The core of the ring composition, therefore, is Hera's ultimate desire for a mighty child, one capable of defeating Zeus. Hera gives birth to Hephaestus, but is deprived of any hope of

\footnotetext{
${ }^{26}$ Allen-Sikes-Halliday (1936)ad loc. follow earlier editors in assuming a lacuna between 317-318,

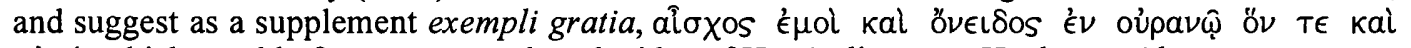
airtí, which would of course strengthen the idea of Hera's disgust at Hephaestus' lameness.

27 Cf. Chapter I, Sections 1 and 3.
} 
activating Thetis' potentiality; accordingly, as she strikes the ground with her hand

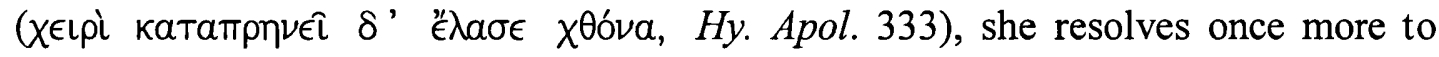
have a child, this time with the aid of the chthonic power of Gaia.

The narration gives full details of Hera's generation of a child, and this presents a clear contrast with Leto's maternal experiences. In the account concerning Leto, there is great emphasis on her happiness as a mother, although she has to search for a place where she can give birth:

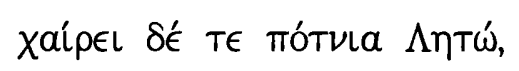

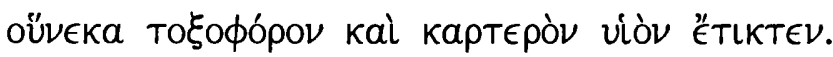

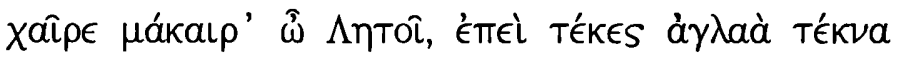

...mighty Leto rejoices,

because she bore a valiant son who carries the bow.

Hail, O blessed Leto, because you bore illustrious children

(Tr. A. Athanassakis)

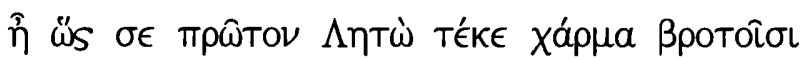

Shall I sing how first Leto bore you, a joy to mortals

(Tr. A. Athanassakis)

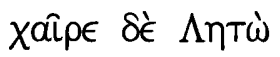

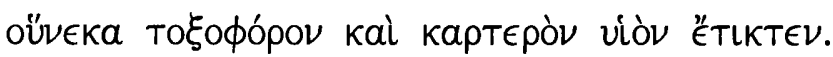

Leto rejoiced

For giving birth to a mighty son who carries the bow.

(Tr. A. Athanassakis)

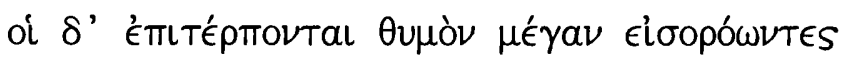

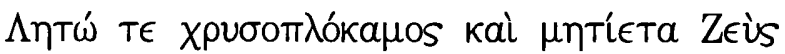

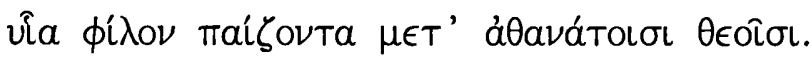

(204-206) 
And Leto of the golden tresses and Zeus the counselor rejoice in their great souls as they look upon their dear son playing among the immortals. (Tr. A. Athanassakis)

In lines 204-206, Leto shares her happiness with Zeus: many gods gather, singing and dancing (188-201), and Apollo plays the lyre among them (201-203) while Zeus and Leto rejoice to look at him.

In contrast, Hera is angry and solitary. Her anger and resentment are emphatically repeated: she gives birth to Typhon, being angry ( $\chi \circ \lambda \omega \sigma \alpha \mu \epsilon ́ v \eta)$ at Zeus

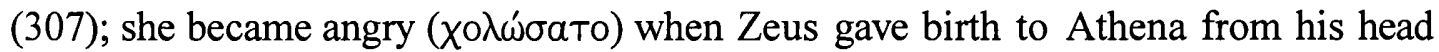
(309); she remained aloof from the gods, being angry ( $\left.\chi \omega о \mu \epsilon^{\prime} \eta, 331\right)$; and she

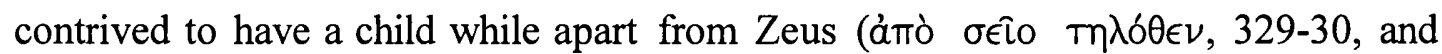

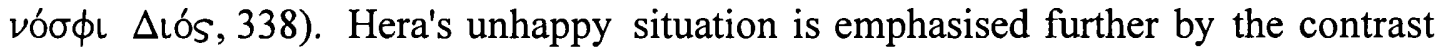
between their sons: the outstanding Apollo on the one hand, and the crippled Hephaistos or monstrous Typhon on the other. Moreover, it serves to echo the jealous rivalry that inspired Hera to keep Eileithuia away from Leto (99-101); similarly, it is designed to show that she is condemned and punished for her malice concerning Leto's travail. ${ }^{28}$ Finally, her rebellion against Zeus is accentuated: Hera is now going to punish him. In response to Zeus' contrivance ( $\mu \eta \operatorname{li} \sigma \in a \iota 322)$, she, too, will engineer something ( child who is stronger than Zeus in proportion to the strength that Zeus has over

\footnotetext{
${ }^{28}$ Fontenrose (1959) 18 gives another version of the myth: Hera put Earth under oath not to let Leto bear her children, but Poseidon gave Leto refuge on Delos when the dragon was pursuing her (Hyg. $F a b$. 140). This may be connected with the mysterious account of the temple of Poseidon at Onchestos, 230-238. Janko (1986) 55 notes the power relations between Poseidon and Apollo: Poseidon's shrine is central to Boeotian patriotism, and Telphousa's overthrow by Apollo is the key to the control of the road between Thebes (Poseidon's domain) and Delphi (Apollo's domain).
} 
Kronos (339). ${ }^{29}$ So far as the narrative of the hymn reveals, the result is uncertain:

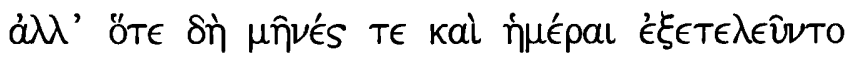

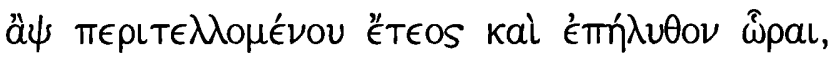

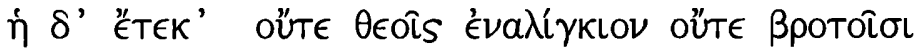

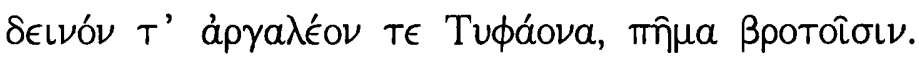

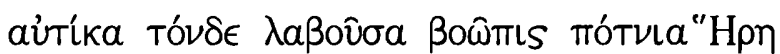

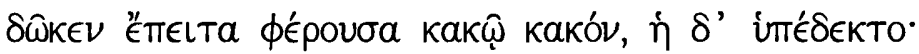

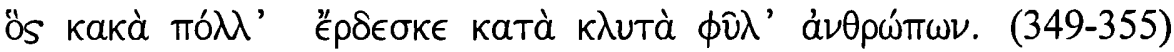

But when the months and the days reached their destined goal, and the seasons arrived as the year revolved, she bore dreadful and baneful Typhaon, a scourge to mortals, whose aspect resembled neither god's nor man's.

Forthwith cow-eyed, mighty Hera took him and, piling evil upon evil, she commended him to the care of the she-dragon.

He worked many evils on the glorious races of men. (Tr. A. Athanassakis)

It is emphatically reiterated that Typhon's advent is a calamity for human beings $(352,355)$; but to what extent is he also harmful towards the gods? It is curious that Typhon's threat to the gods is not mentioned at all -- although it must have been well known to the audience -- whereas the consequences of his nature for humans are stressed: this is not mentioned in the Hesiodic version. According to this hymn, Hera's only intention is to have a child who is mightier than Zeus (338), and she does not care whether the child is beneficent towards humankind or not. Although the details are ambiguous, we may read this intricate treatment of the motif as an implication that Hera is contriving something sinister for Zeus, and that this involves

\footnotetext{
29 Janko (1992), in his commentary on Il. 14. 295-6, suggests the existence of a tale of threat to Zeus' rule in which Zeus secretly seduces Metis, since, in Hesiodic fragment 343, Metis' child is greater than Zeus. Cf. Chapter IV, Section 3.
} 


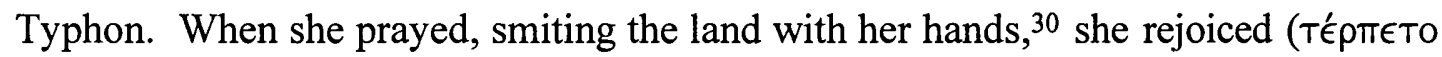

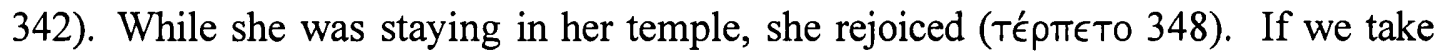

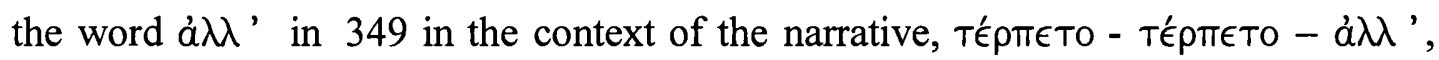
the result is disappointment for Hera: her child does not fulfil her expectations. ${ }^{31}$

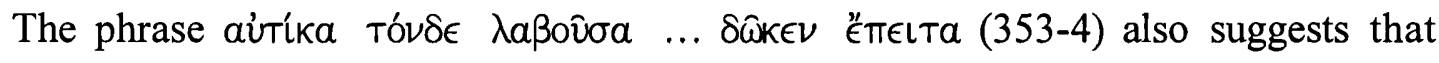
Hera does not like this child, since it is not stronger than Zeus. Although it was customary for the children of good families to be reared by nurses, and Hera could simply be handing her child over to a nurse, something more can be inferred at line 353-4; aùtíka (at once) is stressed due to its emphatic position as the first word of the line ${ }^{32}$ and it can support several interpretations here: first, the nature of the creature is so alarming - since it is not like the gods nor humans $(351)^{33}$ - that Hera is prompted to hand the creature over at once; second, Typhon should at once be protected and shielded from attack by Zeus, just as Zeus himself was shielded in the cave on Mount Ida in Crete; third, Hera may not have a deep affection for Typhon. Since nothing more is said about Typhon, the exact consequences of Hera's contrivance are equivocal: but the implication is that the 'dreadful' child might - as Hera wished - do something truly 'dreadful'. To this I would add that his dreadful

\footnotetext{
${ }^{30}$ Beating the ground always expresses a desire for revenge. In the Meleagros story, Althaia beats the ground in a similar way (Il. 9. 568-9). The chthonic character of Hera also appears in Il. 14. 271$279,15.34-38$.

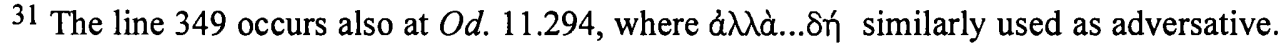

$32 \mathrm{~A}$ child is handed over for nurture in mythic stories; for example, Zeus is nurtured by Gaia (Theog. 479-80); Achilles is fed and educated by Phoenix in the Iliad (9.485-95), and by Chiron in other version; Aristaeus, the son of Apollo and Cyrene, is brought by Hermes to Horae and Gaia to be nurtured (Pindar, Py. 9.59-63). These stories show that it was a common custom for a child to be reared not by his/her mother, but by a nurse (or nurses). The phrase aủTíкa ... ढ̈ $\pi \epsilon \iota T a$ (353-4) in the present text makes a strong focus on Hera's hurried action, 'taking him (the child) at once, she then gave him to...', which seems to convey an atmosphere somewhat different from the ordinary.

${ }^{33}$ Theog. 295-6 gives similar verses with 351-2 on Callirhoe's giving birth to Echidna: î $\delta$ ' 'ै

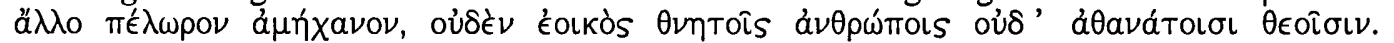

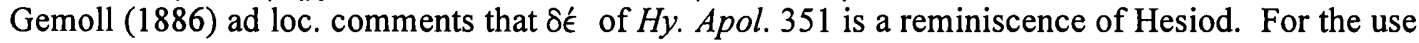
of apodotic $\delta \dot{\epsilon}$, see Denniston (1954) 177-181.
} 
nature is further heightened by the nurse, as the phrase кaḳ̂ кakóv (354) shows.

This passage forms the last part of the digression, after which the hymn returns to the main narrative: the transition is as abrupt as the initial switch at the beginning of the digression:

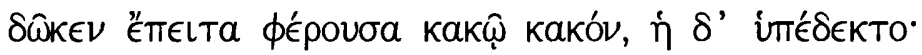

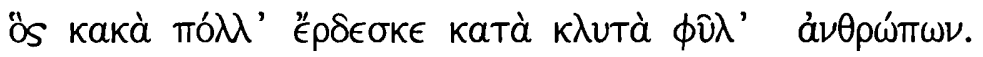

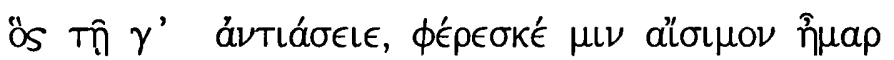

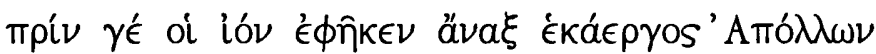
картєрóv. (354-358)

Forthwith [Hera] took him and, piling evil upon evil, she commended him to the care of the she-dragon. He worked many evils on the glorious races of men, and she brought their day of doom to those who met her, until the lord far-shooting Apollon shot her with a mighty arrow; (Tr. A. Athanassakis)

The main narrative begins with ôs at 356 , then we have ôs twice in the same position in the two consecutive lines. Curiously enough, however, these denote two different objects: the former ôs (355) is Typhon, the latter (356) is somebody unspecified (whoever) ${ }^{34}$; and, the subject changes in the apodosis ('Whoever might meet her, the day of doom would carry him away'). of (357) refers to Ṭ̂ (356), and this $T \hat{n}$ refers to $\dot{\eta}$ (354). These pronouns denote the dragon, and are straightforward, but, at the same time, they give the impression that something linguistically intricate is happening: I contend that this repetition of pronouns is an

\footnotetext{
${ }^{34}$ In order to avoid the abruptness at 355 , scholars used to propose emending the text; the most popular suggestion was Wolf's $\ddot{~}$ (to denote the female dragon), but edition are now more inclined to accept the text as it stands. See Càssola (1975) ad loc.
} 
effective device to give special emphasis to the dragon. ${ }^{35}$ Moreover, the abrupt transition caused by the asyndeton at 356 also attracts our attention. The cumulative effect of these somewhat unusual narrative features is twofold: (a) a truncation for dramatic effect on the audience; ${ }^{36}$ (b) the style of narrative might also be identified with oracular diction. The Delphic oracle was renowned, as we are informed by Heraclitus, ${ }^{37}$ for its ambiguous utterances. The messages were sometimes astonishingly compact and abrupt, (and could lack both explanation and understandable context) and are thus analogous to the abruptness of this hymn. Omission of the subject or object in the oracles, which led to the terrible mistakes of Kroisos (Herod. 1. 53, 71), and Nero (Suet. Nero, 38$),{ }^{38}$ clearly recalls this hymn's narrative technique. The use of such a conspicuous style in the final part of the digression would seem to communicate some unexpressed, or inexpressible, message. Is the implication that Hera succeeds, however temporarily? Since this hymn is to Apollo, the digression must be stopped before that account is rendered.

Typhon plays an important role in other mythic versions as a challenger to Zeus. According to Apollodorus (1.6.3), Typhon overpowered Zeus and rendered him impotent by removing his sinews. He hid the sinews in the Corycian cave, where they were guarded by the Spákaıva Delphyne. In the Theogony, the defeat of Zeus is omitted (naturally, in view of the purpose of the poem), but his great difficulty in achieving victory is implied. Only after endless clamour and fearful

\footnotetext{
35 The repetition of the pronouns, at the same time, makes a strong contrast with the word play that begins with $\pi u ́ \theta \in U$ (363), as was mentioned above, n.10.

${ }^{36}$ Some other examples of an abrupt transition from a digression to the main story are Il. 9.564-5; Pi. Py. II 37-8.

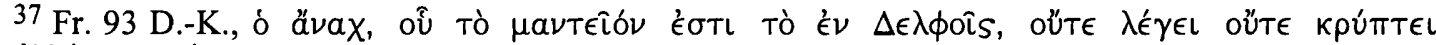

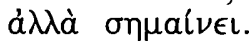


fighting does Zeus raise himself up (851-853). ${ }^{39}$ These versions may imply that

Typhon was almost as strong as Hera wished, and that Zeus was actually in danger of being overthrown. ${ }^{40}$

In the hymn, despite his brief mention, Typhon is a threat to the maintenance of Zeus' power. Since Gaia has ceased to challenge Zeus, Hera may now attempt to destroy Zeus' order by initiating a cycle of succession instrumented by her son Typhon's rebellion. ${ }^{41}$ Indeed it may be Apollo's connection with the Typhon tradition that motivates the inclusion of the digression here. If we consider the killing of the dragon in the context of succession myth, the close association between Apollo and Typhon becomes clear.

It is crucial in the hymn that the dragon is the nurse of Typhon. In the succession myth, Gaia is the nurse of Zeus, who is entrusted to her by Rhea. It is possible to regard the relationship between Gaia and the dragon as analogous; in this case, Typhon is the figure who might have overthrown Zeus, helped by the dragon, just as Zeus overthrew Kronos, aided by Gaia.42 Without Gaia's contrivance (Theog. 485-6; 494), Kronos would have continued to control the universe. Thus, Gaia, the nurse, played the decisive role in the succession myth. A new significance,

38 When the Delphic oracle told him to 'beware of seventy three', Nero supposed that he was to reign till he reached that year; however the oracle alluded to the age of his successor, Galba.

${ }^{39}$ Aeschylus Pr. 353-74, Sept. 511-7 and Pindar Pyth. 1.15-20, 8.16, Ol. 4.7 follow the version in which Zeus has no great difficulty in overcoming Typhon.

${ }^{40}$ Scholia b to Il. 2.783 give a different version, where Hera is in league with Kronos: once, in a rage against Zeus, Hera approached Kronos for help. He obliged by giving her two eggs smeared with his semen which he told her to bury underground: the daimon born from them would dethrone Zeus. After she buried them under Mount Arimoi, Typhon came forth.

41 So in Clay (1989) 68, O’Brien (1993) 96 and Förstel (1979) 262-3. Thalmann (1984) 44 suggests that 'Gaia should turn against Zeus and contrive the birth and survival of the son according to the precedent she has set. Instead, she remains on Zeus' side, for he swallows Metis.' Cf. Chapter IV, Section 3.

42 A large-scale parallel might be implied in the relationship of mother (opposing the ruler)-sonnurse: Rhea (opposing Kronos)-Zeus-Gaia, and Hera (opposing Zeus)-Typhon-the dragon. Clay (1989) 71 notes the parallel between Zeus and Typhon, but goes no further. 
therefore, can be given to the killing of the dragon by Apollo. The dragon (the nurse), by helping Typhon, could have played the decisive role in the usurpation of Zeus, if Apollo had not killed her. Indeed, Typhon is explicitly said to be the presumptive king over mortal and immortal (Theog. 857). By killing the dragon, Apollo inflicts the ultimate injury on Typhon. The killing of the dragon is, therefore, not merely evidence of Apollo's aristeia, but contributes a much deeper significance: Apollo intervenes in the succession myth, alleviating a potential crisis for Zeus.

In short, Hera might have accomplished her goal if Apollo had not come to the aid of Zeus - this seems to be the implication of the hymn. According to Fontenrose, following Otto Gruppe, a story of Apollo's victory lies behind the hymn. ${ }^{43}$ While Apollo's assistance to Zeus is not explicitly narrated, we may read the opening scene of the hymn as the celebration of this victory. ${ }^{44}$

In this opening scene, an assembly of gods is held at the palace of Zeus (2). Apollo, the young heroic god, enters the palace, and when he approaches, bending his shining bow (2-4), the gods tremble and stand up from their seats. The impact is startling: the hymn begins with a scene that appears to imply a potential threat to Zeus' sovereignty. Does it suggest that Apollo has just returned from the battle with the dragon, and is demonstrating his authority among the gods? The next nine lines are significant:

\footnotetext{
43 Fontenrose (1959) 252.

44 Clay (1989) 74 interprets this scene as 'the violent eruption of the usurping son destined to depose his father'. Apollo appears as a threatening figure, as Clay remarks, but it is only when he enters the palace in lines 2-4. The predominant atmosphere of this scene is obviously not fear of violence, but celebration. See also Fontenrose (1959) 252.
} 


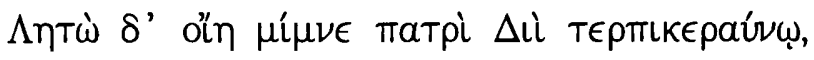

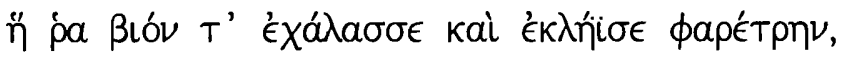

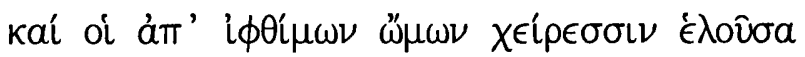

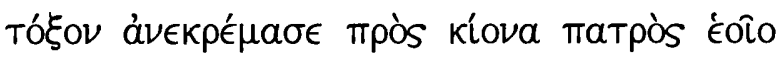

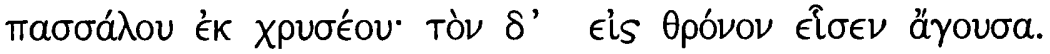

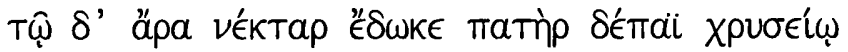

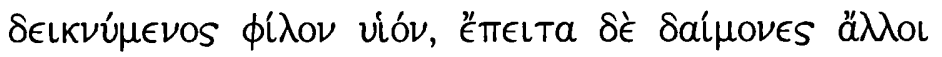

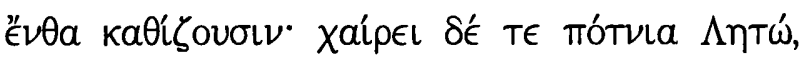

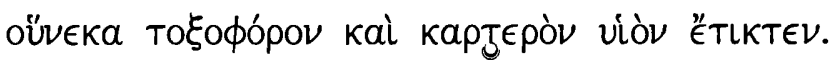

Leto alone remains by Zeus who delights in thunder and she is the one to unstring Apollon's bow and close the quiver; from his mighty shoulders with her hands she takes the bow and hangs it up on a golden peg on her father's pillar, and after that she leads him to a seat. Then his father offers him nectar in a golden goblet and drinks a toast to his dear son; and then the other gods sit down as mighty Leto rejoices, because she bore a valiant son who carries the bow. (Tr. A. Athanassakis)

When Leto puts the bow down and closes Apollo's quiver (6), she indicates that she welcomes Apollo's return; she also makes clear to him that the battle has finished and that these gods are not his enemies. It is she herself who disarms Apollo, taking the bow from his shoulder with her own hands, and hanging it up on the golden peg on the pillar next to his father's seat (7-9). ${ }^{45}$ This elaborate narrative effectively presents Apollo's might, and emphasises the importance of his disarming, which is intensified by Leto's careful handling of his arms. The place where the bow is hung is also meaningful: it is the pillar just behind where Zeus sits. This has three implications: first, that Apollo cannot use the bow without the consent of Zeus (thus Apollo is subject to his power); second, that great honour is given to Apollo's

\footnotetext{
45 Càssola (1975) 486 points out that Apollo's action (v.4) contradicts Leto's disarmament (vv. 6-8),
} but offers no further discussion. 
bow (and to Apollo himself); third, that the pillar symbolises Zeus' power and, therefore, implies that his house stands firm. Next, Leto takes him to his seat (9), signifying that no more fighting should be done. By her action, she instructs Apollo that he should surrender to Zeus. Zeus welcomes his son and himself offers him nectar in a golden cup (10-11). This may be read as a celebration of Apollo's victory over the female dragon at Delphi - but it is also a demonstration of Zeus' gratitude to Apollo, a recognition of his dignity, and also a celebration of an overall peace

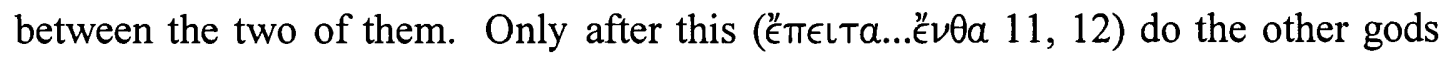
take their seats with relief, and Leto rejoices that she has borne a bow-bearing mighty son (13). Significantly, it is Leto who organises everything. There is a marked contrast between her and Hera: Hera attempts (albeit temporarily) to overthrow Zeus by using Typhon; in contrast, Leto assists Zeus, and acts as a king-maker by influencing Apollo: significantly, Hera is absent from the assembly of gods in the opening scene. The opening scene of this hymn and the digression of the Typhon episode are thus interrelated, and illustrative of the wider struggle for cosmic power.

\section{Telphousa}

The digression has manifold effects, among which is undoubtedly the accumulation of similar motifs that emphasise the importance of the dragon. ${ }^{46}$ Thus three episodes about monsters are presented: Typhon, the dragon (Python), and

\footnotetext{
${ }^{46}$ As Segal (1971) 5-6 suggests, 'the repetitions allow the parallels or divergences of situation to clarify and develop.'
} 
Telphousa. ${ }^{47}$ Let us now consider the Telphousa episode in relation to that of Typhon-Python.

The Telphousa episode is closely related to the Typhon-Python episode. There are obvious similarities, yet conspicuous contrasts as well. Two kinds of similarities - external and internal - occur. Externally, the beautiful spring is

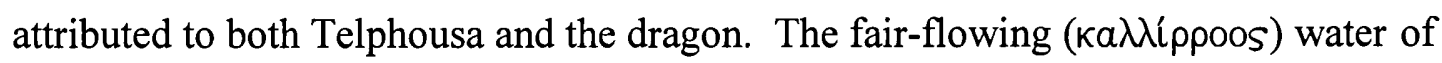
her spring is thrice mentioned $(376,380,388)$, just as the abode of the dragon is also

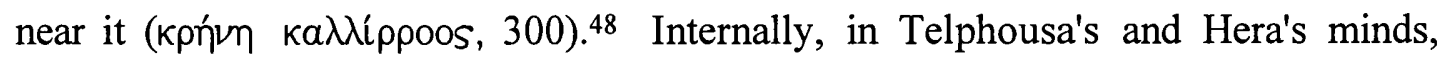

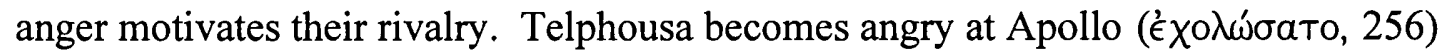
when Apollo begins to build his temple. As was discussed above, in the TyphonPython episode, Hera is also characterised as being angry at Zeus.

Differences between the motifs are noteworthy in several ways: Telphousa seems to have been on good terms with humankind, since humans water horses and mules there (263); however, the dragon and Typhon are both baneful to men (304, 306, 352). Telphousa recognises that Apollo is stronger and mightier than herself (267), but the dragon and Typhon are overweeningly violent monsters. In the light of their opposing characters, it is significant that Telphousa uses the power of persuasion against Apollo, unlike the violence we see in the dragon and Typhon. Her arguments are as follows: she gives sufficient reasons for denying Apollo's offer (262-266), and suggests an alternative that would suit Apollo's intent (268-271).

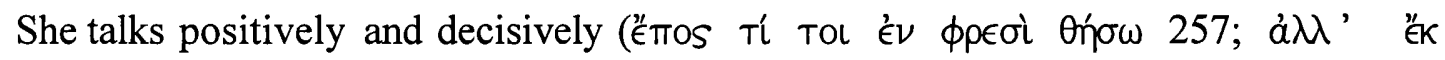

\footnotetext{
47 Fontenrose (1959) 468 writes that 'the Telphousa of the Homeric Hymn to Apollo is a double of the dragoness.'

48 Clay (1989) 60: 'the spot he (Apollo) finally elects for his sanctuary has no natural attraction',

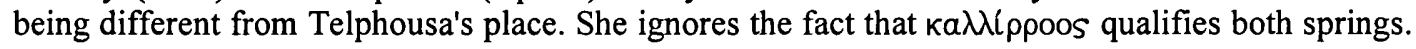




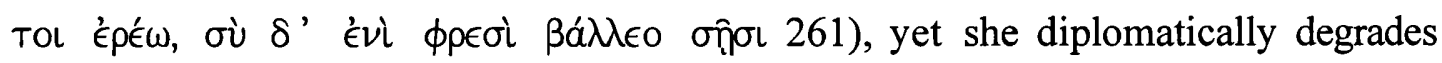

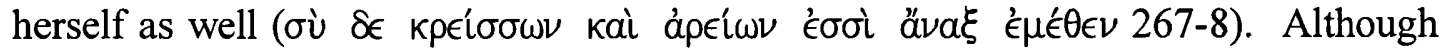
she does not recommend violence, her speech is somewhat deceptive and forceful, since contrivance ( $\delta$ ó $\lambda \circ s$ ) is, in a sense, close to violence ( $\beta i ́ \alpha)$. Her persuasion is effective enough to succeed in changing Apollo's mind for a time. As a result of her deceit, she is punished by Apollo (379); however, although she is not utterly

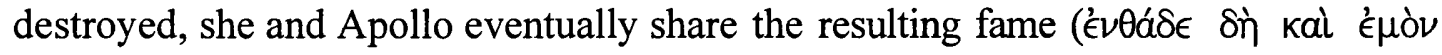

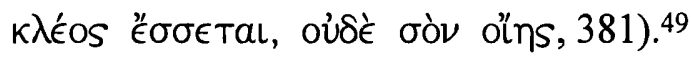

The most conspicuous feature of the Telphousa episode is that words are directly exchanged by Telphousa and Apollo. As mentioned before, Apollo proclaims his intentions to Telphousa and Krisa using the same words, but only Telphousa answers verbally (257-274). Therefore, when Apollo discovers that he has been deceived, and returns in anger to punish Telphousa, he still talks with her (379-381). In the hymn, this Telphousa episode obviously casts light on Apollo as

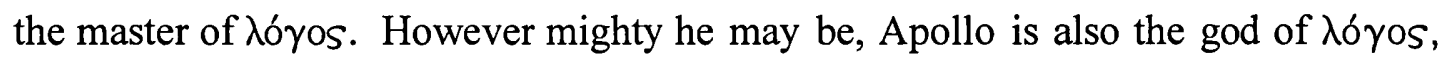
who gives oracles in verbal form - in clear contrast with the oracles of Zeus. ${ }^{50}$ Thus Apollo's dual nature - his mental and physical aspects - enables him to overwhelm both types of opponents. By giving these two extreme examples, the hymn further suggests the full range of Apollo's powers. ${ }^{51}$

\footnotetext{
49 Schol. D ad Iliad 23. 346 gives the story that Poseidon was married to Erinys in the shape of a horse by the spring of Telphousa. Janko (1986) 54-5 suggests that Telphousa was once Erinys in the Boeotian version of the myth, and Apollo's treatment of Telphousa symbolises, first, the antagonism between Apollo and Poseidon, and, second, the religious and political depreciation of Thebes.

50 Strab. Fr. 1a Meineke: 'The oracle of Zeus at Dodona answered by signs rather than by inspired speech.'

51 Thalmann (1984) 1 aptly points to a similar all-encompassing dualism (that of barbarism versus civilisation) in the Odyssey: 'each (the two extremes of the Phaiekes and the Kuklops) seems
} 
In my analysis and argument so far, I have dealt with some characteristics which are peculiar to the digression in this hymn. To sum up, the digression about the dragon demonstrates the compositional technique of a 'story-within-a-story', and this technique increases the importance of the dragon. The abrupt transition back to the main narrative emphasises the doublet of the dragon and Typhon, and also functions as a deliberative device which develops the broader perspective, but leaves the exact linking inexplicit.

The repetition of motifs is another aspect of the digression. The retelling of these two similar stories of violent creatures gives the effect of emphasising their aggressive natures: if Typhon is powerful and harmful, the dragon is more powerful and harmful. The motif of Telphousa also functions to emphasise the dragon's violence. The repetition of motifs is a constant not only in the digression, but also in the whole composition of this hymn. The travels of Leto in search of a favourable place (30-50) are repeated by the similar travels of Apollo (216-228), and the motif of the assembly of gods recurs as well $(2-4,187-206) .{ }^{52}$ The latter assembly of gods is also juxtaposed with the assembly of the Ionian people at Delos (146-164): the people sing about the gods (158-159), and the gods sing of the sufferings of men (190-193). The songs of the Delian girls can be delineated as a further example of this embedding technique, the story-within-a-story, since they are singing the hymn to Apollo, Leto, and Artemis (158-159) within the Hymn to Apollo itself. Structurally and thematically the hymn can indeed be described as a unity, the digression about the dragon being linked to the narrative by the devices of repetition may give shape to what lies between them.' 
and nesting or embedding.

One of the poet's main purposes in selecting the story of the dragon and Typhon was to sing about Hera. By means of Hera's entrance into the narrative, the encomiastic aim of this hymn is fully achieved. Apollo degrades Hera by destroying the dragon and the end result is the winning of great esteem, not only for himself, but also for Leto. The killing of the dragon is, consequently, the most critical moment in the process of establishing Apollo's dignity and position on Olympus. The comment of Austin on the digressions of Homer can be aptly applied to this hymn: 'where the drama is most intense, the digressions are the longest and the details the fullest.' 53 The digression of the dragon, in short, achieves its greatest effect through the development and colouring of the motifs and their arrangement within the structure of the embedded narrative.

52 Miller (1986) 69, 72.

53 Austin (1966) 306. 


\section{Chapter VI : The Bitter Sorrow of Aphrodite}

The Hymn to Aphrodite portrays the problems of love and death caused by excessive intimacy between gods and mortals. The love of Aphrodite and Anchises is mentioned in both the Iliad (2.819-21) and the Theogony (1008-10), but without any detail. The Hymn to Aphrodite develops the theme most ingeniously and dramatically, illustrating the sombre gulf between mortality and immortality.

The date of the hymn would seem to be around the seventh century, ${ }^{1}$ although other dating opinions range from the time of Homer to the Hellenistic period. ${ }^{2}$ It is widely believed that this hymn was composed in honour of noble patrons in the Troad who claimed descent from Aeneas. ${ }^{3}$ As regards the characteristics of this hymn's diction, the use of frequent repetition might be understood as the product of oral composition, ${ }^{4}$ but the possibility of a written composition cannot be totally excluded. ${ }^{5}$ Also detectable are a number of modifications to the verses which are

\footnotetext{
' Allen, Halliday and Sikes (1936) 351 date after Homer and before 700 BC. Janko (1982) 180 is more precise on linguistic grounds, he places the composition of the Hy.Aphr. within Hesiod's own time, between Hesiod's Theogony and Hy. Dem.

${ }^{2}$ On the divergent datings of the Hymn see Janko (1982) 151. Although Bentman (1955) 154-5 dates this hymn to the Alexandrian period on the basis of the poetic technique of its delicate interworkings (such as the use of repetitive patterns), and Càssola (1975) 249 suggests the possibility of a later date because of the hymn's simple and clear structure, but I am persuaded by Janko's arguments (cf. $n .1$ above).

${ }^{3}$ For example, Wilamowitz (1920) 83; Càssola (1975) 244-5. This belief is reviewed by Smith (1981a) 4 and (1981b) 17-8, who claims that there is no historical evidence for the existence of Aeneadae in the Troad; his argument is not convincing enough.

${ }^{4}$ Preziosi (1966) 194. Porter (1949) 254-64 discusses the range of repetitious characteristics of this hymn, such as themes, metre, sound (assonance, consonance), and concludes (p.272) that the technique of repetition in the Hymn to Aphrodite is much more elaborately developed than in the Iliad.

${ }^{5}$ Janko (1982) 19 gives the markers of an oral style, but says (p.180) that, unless new technical criteria are discovered, it is difficult to decide whether an oral poet could have created such a masterpiece.
} 
thought to represent a later stage of development in epic diction relative to that of Homer; ${ }^{6}$ the numerous similarities with the Hymn to Demeter are also noteworthy. ${ }^{7}$

The theme of this hymn - the love affair between a goddess and a mortal - is romantically appealing, and indeed the hymn starts in a happy mood. Some have argued that the dominant tone of this hymn is humorous. ${ }^{8}$ I submit, however, that, while there are some elements of humour, there is nevertheless a poignant recognition of mortality which resonates throughout the whole hymn. ${ }^{9}$ Rutherford's comment on Sophoclean tragedies is appropriate to this hymn: ${ }^{10}$ the optimistic tone signalled at the beginning creates a clear contrast with the result of the affair which follows. In the case of this hymn, the dramatic function of the opening 'joy' is deliberately designed to emphasise the pessimistic outcome of its latter half.

At the end of the hymn there is a passage praising the nymphs (256-80), which does offer some joy and consolation, but the predominant tone is tragic, since even the nymphs die eventually (269-72). Unlike other hymns, which end with the triumph of the gods, Aphrodite is here defeated by Zeus. ${ }^{11}$ It seems that the poet's strategy is to subordinate Aphrodite to Zeus' power, and that this occurs as a

\footnotetext{
${ }^{6}$ Hoekstra (1969) 46.

${ }^{7}$ As the result of discussion of the similarities between Hy. Aphr. and Hy. Dem., Janko (1982) 163-5 concludes that Hy. Dem. is secondary.

${ }^{8}$ Walcot (1991) 141.

${ }^{9}$ The brevity of mortal life as a theme of this hymn is noted by many scholars. See, for example, Gemoll (1886) 258; Porter (1949) 259; Boedeker (1974) 79; Smith (1981a) 5; Sowa (1984) 40; Parry (1986) 263-4; Clay (1989) 158. Among these, I favour primarily the assessment of Smith.

${ }^{10}$ Rutherford (1982) 146.

${ }^{11}$ Heitsch (1965) 12 emphasises the defeat of Aphrodite. As the hymn celebrates neither the birth of the goddess nor the founding of her cult, Matthiae (1800) 66 even doubted whether this hymn should be considered a hymn (Sed mihi quidem valde dubium est, an carmen illud in hymnorum numerum omnino referendum sit). Clay (1989) 170 posits that this hymn conveys an epoch-making event similar to the themes of the other three long hymns: the last union of a god with a mortal to produce
} 
response to generational strife. The message of this hymn is tragic, and I suggest that it operates on two levels: on the one hand, through the recognition of human limitation, effectively emphasised by the perceptible use of ironical or ambiguous words; on the other hand, through the recognition of the limitation of Aphrodite's power, which is explicitly and implicitly evident in her subjection to Zeus. I discuss these two levels, emphasising, in particular, how they are related to the encomiastic purpose of the hymn. I also suggest that the phrase 'bitter sorrow' (aivòv ä aos, 1989) which characterises this hymn, serves to unify the two levels of its message.

\section{Human limitation and irony}

When the poet narrates the love affair between Aphrodite and Anchises (53-167), he uses ironic and paradoxical words. Such diction fits well with the hymn's cautionary tone: dangerous consequences are inevitable if the distinction between mortal and immortal is blurred. In the deceptive speech of Aphrodite, the boundary between truth and falsehood is also equivocal, and the ironical words effectively emphasise the fluctuation of this boundary.

The opening scene of their encounter is sharply marked by the prominent mention of Anchises in 53, and tóte in 54 draws attention to his way of life and physical beauty at that time when he was tending his father's cattle:

the last hero. Fränkel (1975) 248 also mentions that the conclusion implied in this hymn is that man and goddess must now part for ever. 


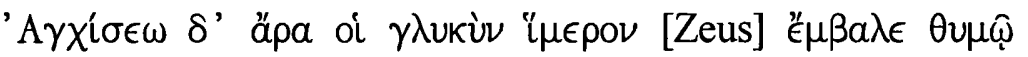

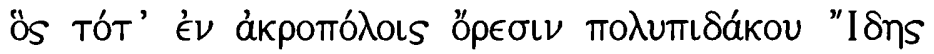

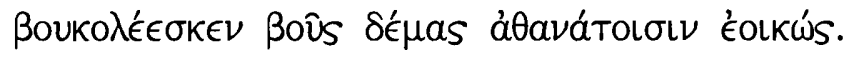

(Hy. Aphr. 53-5)

And so he placed in her heart sweet longing for Anchises

who then, looking like an immortal in body,

tended cattle on the towering mountains of Ida, rich in springs.

(Tr. A. Athanassakis)

After their love affair, when the narrative returns to the mundane world with a description of Anchises' fellow herdsmen, we read:

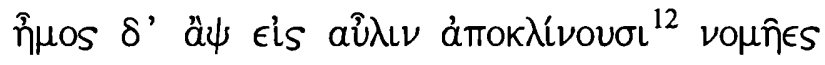

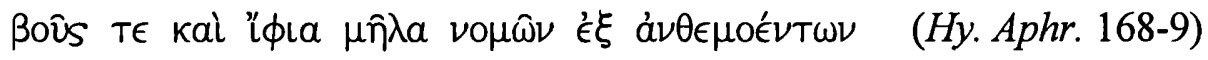

And at the hour shepherds turn their oxen and goodly sheep back to the stalls from the flowering pastures (Tr. A. Athanassakis)

By encircling the narrative with the two words for time, Tótє (54) and $\hat{\eta} \mu \circ$ (168), the poet intensifies the singularity of this encounter between goddess and mortal.

Anchises is described as 'like an immortal' (55). His appearance is mentioned in this hymn only twice: here at 55 , and in 77 . In both verses he is compared to an

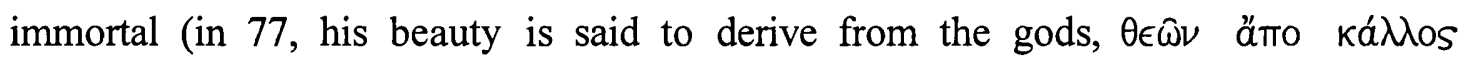
É $\chi \circ \nu \tau a) .{ }^{13}$ It is worth noting that this meagre description is in distinct contrast to the attention given to Aphrodite's appearance, which is described in detail: for example,

\footnotetext{
${ }^{12}$ Smith (1981a) 61 views the present tense of ämок $\lambda$ ivovol as a generic, timeless description. Janko (1981b) 285 , in his review of Smith, rightly points out the poet's ingenious use of time.
} 
her cosmetics, costume and accessories (61-5, 86-90, 162-4), her beautiful cheeks (174), and her neck and eyes (181). In comparison, Anchises' appearance remains impressively unelaborate. It is ironic how the simplicity of description -- he is a human who looks like a god -- works to emphasise how dangerously close he stands to the boundary between human and divine.

When Aphrodite appears before him, she is described as follows:

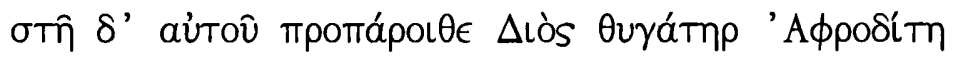

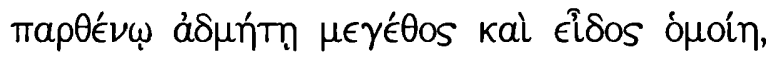

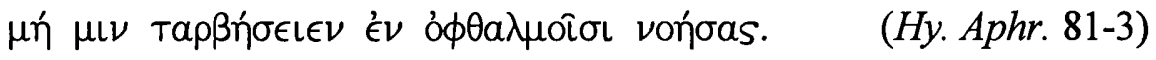

And Aphrodite, the daughter of Zeus, stood before him, in size and form like an unwed maiden, so that he might not see who she was and be afraid. (Tr. A. Athanassakis)

She, too, stands at the point of boundary: a god pretending to be a human, she is divine yet looks human. ${ }^{14}$ Yet she does not try to conceal her true identity; indeed, as Smith suggests, 'she wants to show herself unmistakably a goddess.'. ${ }^{15}$ Since the Graces, who symbolise the embodiment of beauty, bathe and anoint her with immortal oil (61-2), Aphrodite shines more than ever.

We note how peculiarly ineffective this disguise is, particularly in light of general opinions held about the disguises of the gods: 'their disguises are alien to their

\footnotetext{
${ }^{13}$ This phrase could also imply that he is a descendant of Zeus; his grandfather is a son of Zeus.

${ }^{14}$ Smith (1981a) 44 points out that such a paradoxical combination of mortal and immortal in their appearance assists the audience's acceptance of their union as lovers.

${ }^{15}$ Smith (1981a) 42-3.
} 
true nature'. ${ }^{16}$ For example, Demeter, in the Hymn to Demeter, disguises herself as an old woman in such a way that no one knows who she is (94-5). In the Hymn to Aphrodite, however, it is Aphrodite herself who stands in front of Anchises. Although she disguises herself as a Phrygian girl, her beauty in fact possesses - retains - a superhuman quality, emphasising, again, the peculiar use of irony in this text: this is not a 'disguise' in the true sense at all. ${ }^{17}$

Love appears to be a very human emotion. This provides us with another explanation for Aphrodite's disguise: gods cannot appear as themselves when they desire to mate with humans; thus Zeus comes to Ganymede as an eagle, or to Io as a bull. ${ }^{18}$ Even if gods were susceptible to mortal charms, what they express must be differentiated from human 'love'. As gods are invulnerable to death and are constrained to leave dying mortals, ${ }^{19}$ so too must their attitude to love - and the beloved - differ.

The exceptional difference in their situation - the unimaginably beautiful Aphrodite and the apprehensive Anchises - is deliberately expressed in their first words. Anchises asks the identity of Aphrodite, offering the names of five goddesses, the Graces and the Nymphs:

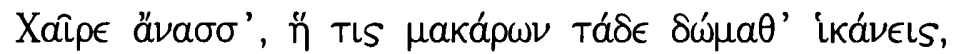

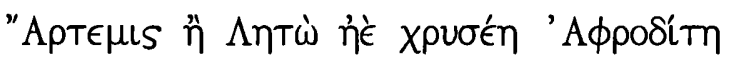

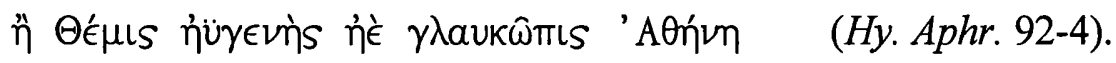

\footnotetext{
${ }^{16}$ Murnaghan (1987) 14.

${ }^{17}$ Bergren (1989) 13 emphasises the ambiguity of Aphrodite's disguise: in the presentation of herself to Anchises, the 'real' Aphrodite comes as an imitation of the 'real' Aphrodite.

${ }^{18}$ Could this suggest that gods were not believed to differentiate overly between animals and humans?

${ }^{19}$ For example, Apollo leaves Hector (Il. 22. 213); Artemis leaves Hippolytos (Eur. Hipp., 1437-9).
} 
Lady, welcome to this house, whoever of the blessed ones you are:

whether you are Artemis, or Leto, or golden Aphrodite,

or well-born Themis, or gray-eyed Athena (Tr. A. Athanassakis)

This long list of goddesses shows both how apprehensive he is and how eagerly he desires to know her identity. ${ }^{20}$ At this stage Anchises does not know anything about this beautiful girl who suddenly appears before him, so he can only wonder at and admire her form and height (84). His words may also be a standard Greek 'pick-up line': a manner of speech to use for every passing girl. The obvious irony here is that she really is a goddess.

Aphrodite, on the contrary, calls Anchises by name without adding any title:

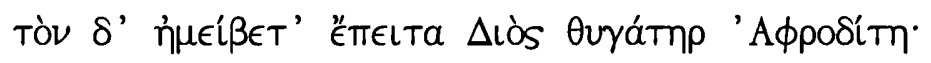

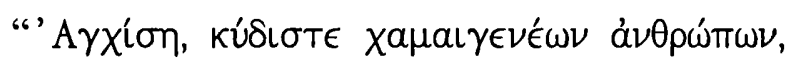

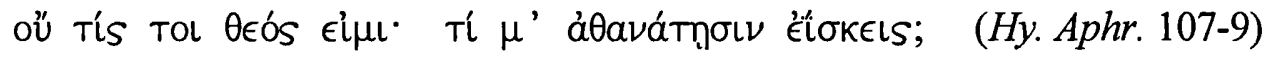

And then Aphrodite, the daughter of Zeus, answered him:

"Anchises, most glorious of all men born on earth,

I surely am no goddess; why do you liken me to the immortals?

(Tr. A. Athanassakis)

Her speech is ironically coloured from the very beginning. Aphrodite knows his name, though she has just met him, and does not address him by his patronymic. The vocative 'A $\gamma$ xion, significantly the first word of the line and the first word of her first speech, is forceful enough to overwhelm him. It is a startling beginning to a speech by 


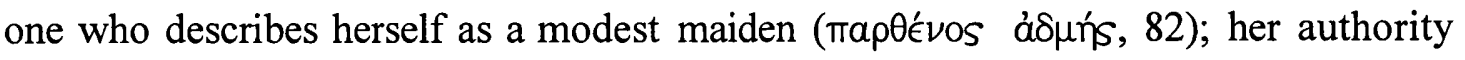
and assurance unmistakably denote that she is beyond human, and the overt nature of these qualities can be read as the verbal counterparts to her disguise. ${ }^{21}$

This initial ironic tone governs the tenor of her whole speech. After addressing Anchises by name, she calls him 'most glorious of men who are born from the earth'

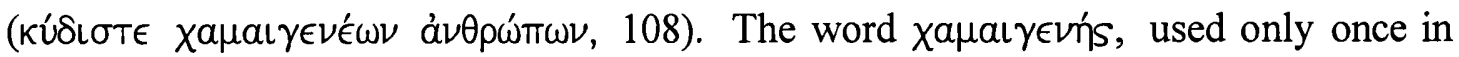
the Hymn to Demeter and the Theogony, has connotations of the humble, emphasising the negative and weak side of human beings:

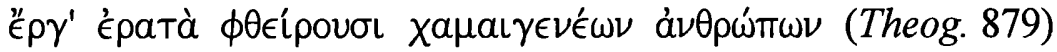

(winds) spoil the lovely fields of men who are born from the earth (My translation)

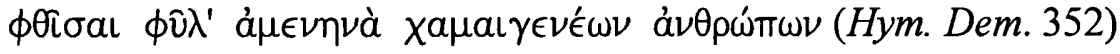

in order to destroy the feeble human race who are born from the earth ${ }^{22}$ (My translation)

It is worth noticing that both of these verses contain the word $\phi \theta \in i \rho \omega$, which strengthens the negative connotation of $\chi \alpha \mu a \mathrm{\gamma} \gamma \in \eta^{\prime} s$. Given that the connotations of

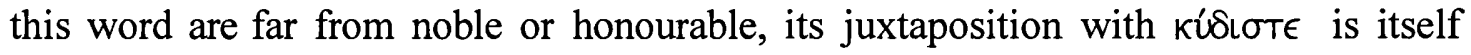
highly ironical. Moreover, as the phrase $\chi \alpha \mu a \iota \gamma \in \nu \in \epsilon^{\prime} \nu \nu$ a $\nu \rho \rho \omega ́ \pi \omega \nu$ is metrically

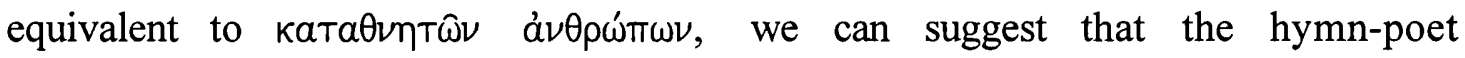

\footnotetext{
${ }^{20}$ Although Walcot (1991) 145 argues that 'the list artfully conceals the true answer', there seems to be no reason why Anchises must 'conceal the true answer'.

${ }_{21}^{21}$ I agree with Clay (1989) 175-6 that Aphrodite's speech and disguise are complementary.

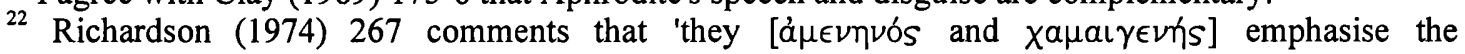
helplessness of human beings.'
} 
intentionally chooses the former. ${ }^{23}$ Anchises is a prince, fifth generation after Dardanos, a descendant of Zeus (Dardanos is a son of Zeus); but in spite of his noble birth, Aphrodite uses the humble word $\chi a \mu a \imath \gamma \in \nu$ 's in order to give emphasis to Anchises' mortality.

Aphrodite, on the other hand, is introduced in the preceding verse as a daughter of Zeus ( $\Delta$ iòs $\theta v y a ́ t \eta p, 107)$. This epithet is metrically equivalent to Aphrodite's other epithet, $\phi\left(\lambda o \mu \mu \epsilon \iota \delta n s .{ }^{24}\right.$ Since this breaches the epic principle of economy formulated by Parry, ${ }^{25}$ a choice between these two epithets is possible. ${ }^{26}$ Here, in 107, $\Delta$ iòs $\theta u \gamma a ́$ tmp is used specifically to highlight Aphrodite's superior origin, in direct contrast with $\chi a \mu a \iota \gamma \in \nu \eta \dot{s}$.

The scene of this encounter has been likened by some critics to that of the meeting of Odysseus and Nausikaa, as the first words of Odysseus are similar to those of Anchises. ${ }^{27}$ However, in the Odyssey, Nausikaa, in the modest manner appropriate to a princess speaking to a stranger, never asks Odysseus' name, and in her first words addresses Odysseus as $\xi \in \hat{\imath} \nu \in$ (6.187). In the Hymn, on the other hand, the manner of Aphrodite's address to Anchises sounds exactly like the speech of a

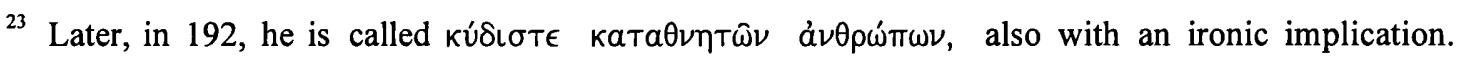
Janko (1982) 25 suggests that $H y$. Aphr. 108 might have adopted a 'Hesiodic' phrase, along with

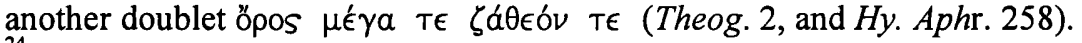

${ }_{24}^{24}$ Boedeker (1974) 31 .

${ }^{25}$ Parry (1971) 16-8.

${ }^{26}$ Janko (1981a) 254-5 discusses the distribution of the equivalent formulae $\phi(\lambda \circ \mu \mu \epsilon \iota \delta$ iे

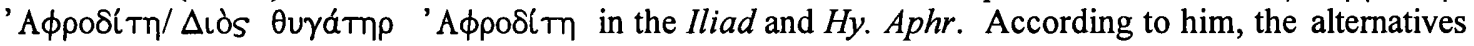
appear in random fashion in the Iliad; but in the Hy. Aphr. strong formulaic association decides the choice in 107=191, while in the first part of the hymn the hymn-poet appears to forget about the existence of the doublet. However, the hymn-poet deliberately seems to prefer $\Delta$ iòs $\theta u \gamma a ́ m \rho$.

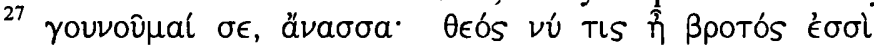

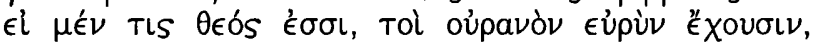

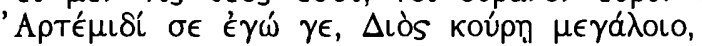

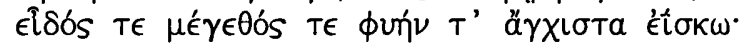

(Od.6.149-152)
} 
goddess, not of a mortal princess; but the irony is particularly apparent in the next two lines when she strongly denies that she is a goddess (109-110).

After Aphrodite's fervent denial of her true identity, she begins the false story by which she introduces herself. She offers a highly rationalised explanation, anticipating Anchises' questions; first, how she is able to speak the Trojan language:

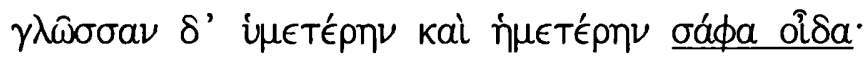

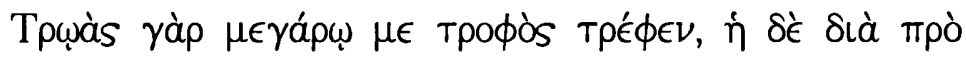

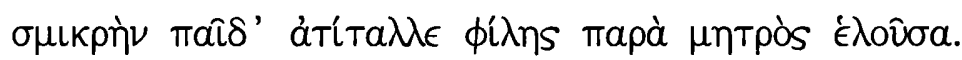

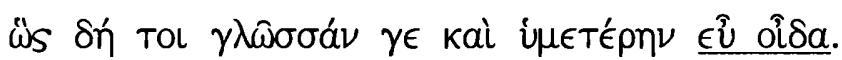

And I know well both my language and yours, for a Trojan nurse reared me in my house; she took me from my dear mother and devotedly cherished me when I was little. For this reason indeed I know your language too. (Tr. A. Athanassakis)

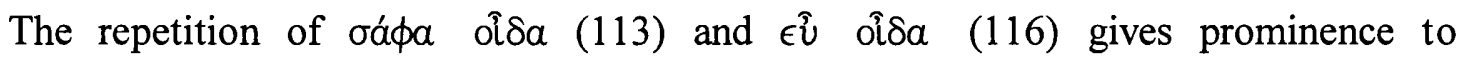
Aphrodite's knowledge of language; at the same time, she insinuates (again, ironically?) Anchises' own ignorance. Aphrodite knows not only Anchises' language, but also his identity, and even what is to happen next. Anchises, on the other hand, does not (we presume) know her language (Phrygian?), her identity, or, least of all, what she is going to do. The more emphatically the poet repeats the idea that Aphrodite knows something, the more clearly the audience become aware of the corresponding implication: Anchises knows nothing. This passage, too, reinforces for the audience that Anchises is only mortal and has only the limited knowledge permitted to a mortal man. 
Her second explanation, in the next fourteen lines, accounts for how she comes to be there (117-130). This scene deserves close attention, because it is underscored by a complex irony. The story she tells is equivocal and duplicitous: the disguised Aphrodite, who tries now to seduce Anchises, describes her own abduction by Hermes. Who is the real seducer, and who is really seduced? As a seductress, Aphrodite takes the initiative and holds overwhelming power; but as a maidenly abductee, she blatantly places herself in a position of complete - and mortal weakness. $^{28}$

Aphrodite pretends to be confident of persuading Anchises that she is a young princess abducted by Hermes, and the unusual situation itself contributes to the mysterious aura that surrounds Aphrodite. Anchises is kept uncertain about her identity right up to the middle of the Hymn, and this account of Hermes' abduction only serves to make him more hesitant about the true identity of this girl. So, while her speech appears persuasive enough to make him decide on pursuing a seduction, it seems that he might still be considering whether she is, in fact, a goddess. For

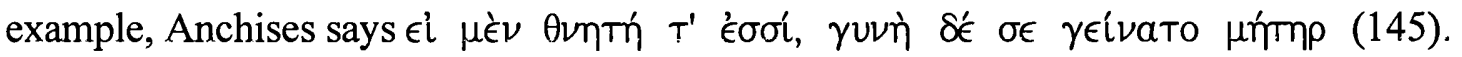
He is very careful about his words in this conditional sentence, especially in using the indicative $(\dot{\epsilon} \sigma \sigma i) .{ }^{29}$ He tries not to include any sense of doubt, leaving it as a simple

\footnotetext{
${ }^{28}$ Clay (1989) 177 suggests that the reason for using a common abduction motif is to titillate and inspire Anchises - to give him 'ideas'. I doubt whether the element of titillation is included here, but I agree with Clay's point (p.159) that Aphrodite has made herself appear the weaker of the two.

${ }^{29}$ I agree with Smith (1981a) 55 that this conditional sentence recapitulates the main point of Aphrodite's narrative. Smith skilfully asserts that it does not matter whether what she says is to be taken as true or false; if it is true, there can be no harm; if it is false, he may hope to escape blame by appealing to the literal content of what she said.
} 
conditional, but the apodosis of this conditional is rather curious if he is going to make love to a mortal woman:

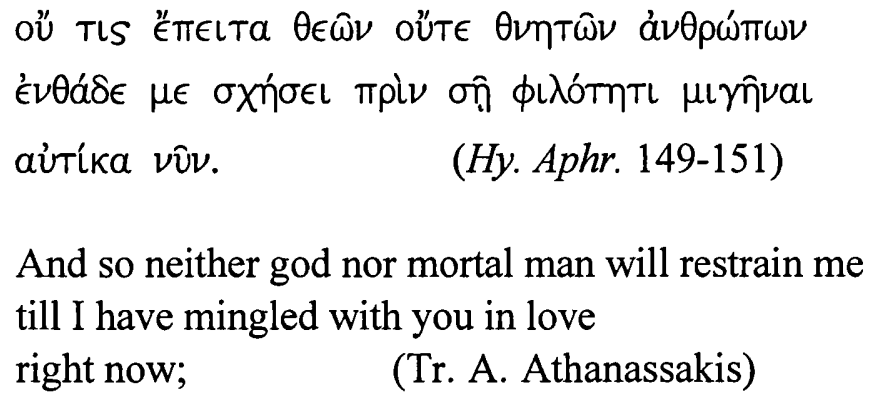

On the surface, it appears that this is simply a negative statement to indicate that nothing will stop him. However, the strong negative sentence with ov in the initial position may also illustrate his doubt and fear: he anticipates that something -- divine or mortal -- might intervene in their love to prevent it. This strong denial paradoxically suggests that he still feels some uncertainty. By expressing his feeling in this way about the possibility of divine or human intervention, he might be trying to push aside his fear. So, possibly, he is still uncertain about her identity.

Is Anchises finally persuaded or deceived by Aphrodite's speech? It appears that the hymn-poet deliberately suggests an ambiguous non-resolution:

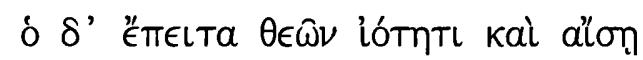

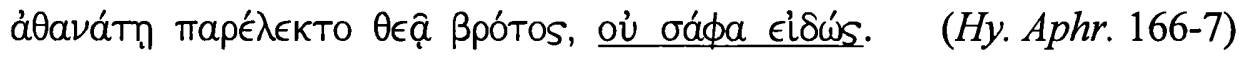

Then by the will of the gods and destiny he, a mortal, lay beside an immortal, not knowing what he did. (Tr. A. Athanassakis) 
The poet says that Anchises has no clear knowledge. ${ }^{30}$ One may assume that Anchises believes her false story and does not know her true identity, ${ }^{31}$ since he is quite aware of the danger of making love to a goddess; however, the phrase, ov oáda

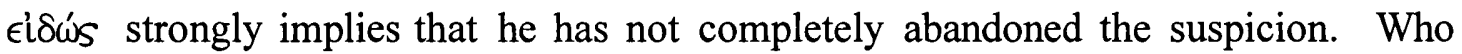
else, other than a goddess, could be so beautiful? Who else could appear suddenly on the top of the mountain? And who else could speak with such dignity? Anchises

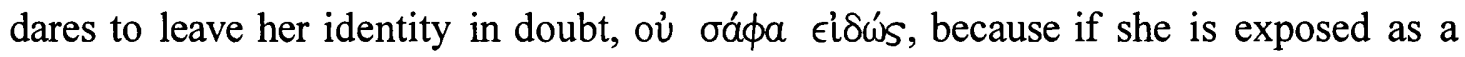
goddess, he also knows that he will be unable to make love to her. The situation present us with what we might call 'self-deception' on the part of Anchises, which forms an ironic counterpart, again, to the flagrant deception wrought by Aphrodite.

The juxtaposition of $\theta \in \hat{a}$ ßpótos (167) is striking as well as ironic. Although this phrase could be derived from the Iliad $(2.821)^{32}$ or from a traditional formula, the poet of the hymn grants it a use more dramatic and impressive than that which we find in the Iliad. I suggest, indeed, that a major theme of the hymn is symbolised in this phrase.

The final part of Anchises' answer helps to confirm the view that he still thinks that she may be a goddess:

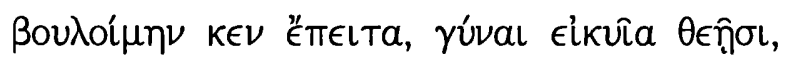

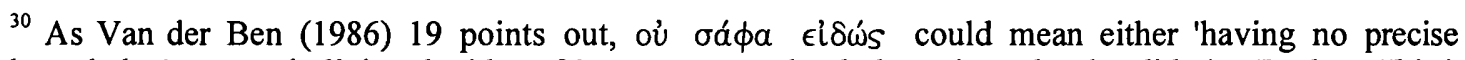
knowledge' - as underlining the idea of $\theta \in \hat{\alpha}$-- or 'not clearly knowing what he did' (tr. Evelyn-White)

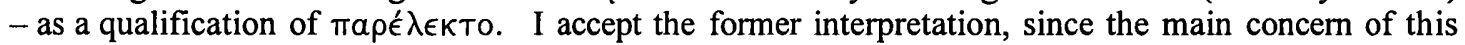
passage is not 'what he is doing', but apparently 'with whom he is making love'.

${ }^{31}$ For example, Clay (1989) 182.

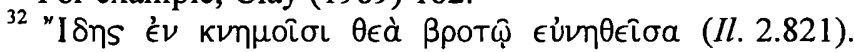




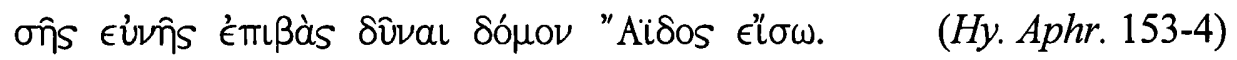

O godlike woman, willingly would I go to the house of Hades

once I have climbed into your bed. (Tr. A. Athanassakis)

Another intentional juxtaposition - that of $\gamma$ v́val and $\theta \in \hat{\emptyset} \sigma \iota$ (153) - builds on the ironic momentum of the moment, since yúval is used only of human women. ${ }^{33}$ Yet this is exactly Aphrodite's rôle: pretending to be human while remaining, intrinsically, a goddess. Anchises was, therefore, quite right in his suspicion of her identity as well as her deception; and now he, too, implies that he believes her speech. The diction of verse 154 is also effective: the line of hissing sigmatism culminates in 'Hades'. More death imagery is given by the playful 'up to your bed' and 'down to Hades'. But even if it were right to suppose that he knows she is a goddess and is joking with her and playing along, the image is a dark one nevertheless: men have indeed died for less than this, such as Actaeon who was punished by Artemis.

The scene after their love-making evokes a dismal mood. In spite of the fact that Aphrodite accomplishes her desire, she feels bitter sorrow. At this moment she should proclaim her victory: she is, after all, the radiant conqueror who took the initiative throughout their encounter and achieved all that she wanted. However, her first words after she awakens Anchises are far from the sweet words of lovers; she is now humiliated by her own act:

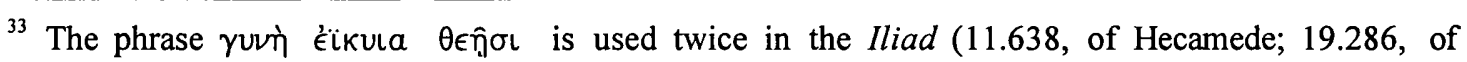
Briseis), where the formula seems to be used less appropriately than in this hymn. See further Smith (1981a) 120 n.59. 


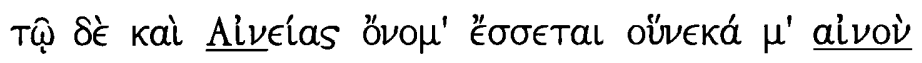

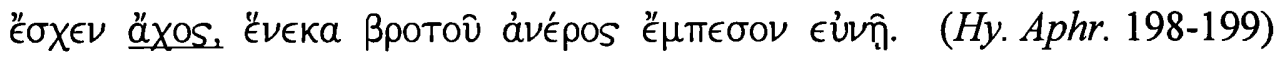

Aineias his name shall be, because I was seized

by awful grief for sharing a mortal man's bed.

(Tr. A. Athanassakis)

The phrase aivòv ăXos is spoken in relation to the name Aeneas - a kind of pseudoetymology of which the Greeks were especially fond. Yet, aivòv äxos has a significance that goes far beyond the simple presentation of an aetiology. ${ }^{34}$ In structural terms, Aphrodite's emotion marks a turning point in the structure of the hymn. Before this stage, everything goes exactly as she wishes, and she appears to be happy and confident in her plans. But, from this point on and throughout the second half of the Hymn, Aphrodite and Anchises are dogged by deep depression. Thematically, the sorrow of 'the blessed goddess' forms the centre of all the ironical expressions built up within the hymn - an effect further heightened by the poet's ingenious device of placing additional thematic emphasis on the name 'Aeneas', by linking it overtly with the aivò̀ äxos of Aphrodite.

As the text shows, her bitter sorrow is primarily caused by the fact that she has slept with a mortal, but a further reason may come from the way in which her immortality is compromised by her disguise as a human. Although Aphrodite

\footnotetext{
${ }^{34}$ Nagy (1979) 82 explains the name of Achilles, following Palmer (1963) 79, as 'the one who has áxos for and of $\lambda a b^{\prime} s^{\prime}$, suggesting that the Homeric theme of áxos reflects not only on the individual nature of the Achilles' figure but also on the collective nature of Achaean גaós. Nagy could have mentioned the aetiology of Aeneas based on aivòv äxos. For the etymology of Achilles from

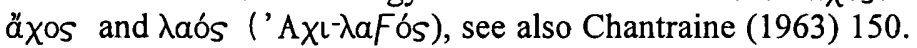


assumes mortal stature ${ }^{35}$, she does not disguise herself completely - if 'disguise' means to become something different from one's own self. She becomes even more beautiful than usual, as was discussed above. Had she met Anchises under a guise completely different from that of her normal self, and succeeded in making love to Anchises because of it, she would have been amused by her own deceitful technique it would be something done for entertainment, like Odysseus' deception at Odyssey 13.256-286. ${ }^{36}$ But in the hymn, even in disguise, Aphrodite is too serious and betrays a demeanour appropriate to her 'mortal' role. Seriousness is not an appropriate attribute for gods, who are immortal; only mortals can be serious, since their lives are short and their abilities limited. Here, although she still has great power as a goddess, Aphrodite conceives and grieves like a human. We see that, not only for Anchises but for Aphrodite as well, 'the boundary between divinity and mortality is perilous and usually catastrophic. ${ }^{37}$ Aphrodite laments her own blurring of this boundary, which will bring about the birth of a mortal child to a goddess.

Aphrodite promises Anchises, who pleads for mercy (196-7), a future lineage of fertile offspring down the generations, and then recounts to him the stories of Ganymede, who is given eternal youth (202-217), and Tithonus, granted eternal life but not eternal youth (218-37). ${ }^{38}$ In this long address, the main concern remains

\footnotetext{
${ }^{35}$ Note the contrast at 173-5; her head reaches to the rafters when she reveal herself that she is a goddess.

${ }_{36}$ In this passage, Odysseus, pretending to be a fugitive from Crete, tells Athena a splendid tale. When he finishes his tale, Athena smiles and caresses him (287-288). She has enjoyed his cunning skill, as has Odysseus himself.

${ }^{37}$ Buxton (1994) 74.

${ }^{38}$ Many scholars believe the story of Tithonus to be the invention of the hymn-poet: Podbielski (1971) 70; Smith (1981a) 84; Segal (1986) 19. Kakrides (1930) 35 and King (1986) 27-8 think that
} 
mortality and immortality. In telling these stories, Aphrodite presents Anchises with her decision. However, we note that, after the stories are told, there is no comment by Aphrodite, and no mention of any response by Anchises - interpretation is apparently left to the audience. My understanding is that both stories are warning examples, illustrating the consequences of mortal transgression, and that Aphrodite, after illustrating the unapplicable fates of Tithonus and Ganymede for Anchises, offers a third and better choice to Anchises.

The story of the aged Tithonus is unanimously accepted as a negative example: ${ }^{39}$ he becomes hated by the goddess who enjoys everlasting youth and, even though he escapes death, he is miserable and has no place among mortals or immortals. The story of Ganymede is more problematic. Those who read the fate of Ganymede in sharp opposition to the wretchedness of Tithonus think that Aphrodite wanted to give Anchises immortality and everlasting youth - as Ganymede had - but she could not. $^{40}$

Immortality, which Ganymedes is offered, might be intrinsically attractive for humans. However, Greek texts are ambivalent on the subject of immortality. For

the story is older than the hymn. The story is not narrated in detail either by Homer or Hesiod, but is mentioned, briefly, in Il. 11.1; Theog. 984-5.

${ }^{39}$ King (1986) 18-20, regarding Tithonus' fate as being worse than that of a mortal man, points out that the poet demonstrates the similarity between gods and men who can unite sexually, and tries to reestablish the distance between the two terms, by choosing the experience of old age, because it is unknown to the gods. Segal (1986) 38 criticises King's article, suggesting that she fails to distinguish between the analysis of a myth and the critical study of a literary text.

${ }^{40}$ For example, Segal (1974) 208 suggests, from a structuralist perspective, that 'Ganymede is given the Olympian privilege of eternal life, and ...Tithonus' horizontal movements to the "limit of the earth" contrast with the vertical movement in the other two [Ganymede and Anchises] episodes'; Boedeker (1974) 80 writes that Aphrodite, like Eos, is apparently unable to offer a deathless existence to her lover of her own accord, since that ability rests with Zeus; Sowa (1984) 40 thinks that, as a fertility goddess, she wanted to make Anchises immortal; Clay (1989) 190 puts the argument that, 
example, when Odysseus is offered immortality by Calypso (Od. 5.203-13), he rejects her offer. He admits Calypso's youth, beauty and divine nature, but he willingly chooses Penelope (and mortality). His rejection offers a significant message: to live as a mortal, however painful, is better than to possess immortality, however happy. I offer a further example: Achilles speaks of human destiny, declaring that mortals live in misery, but gods have no sorrow (Il. 24.525-6). Achilles appears to desire the sorrowless life of gods; however, he never wishes explicitly to live like them. He acknowledges that there is no choice for humans but to live a sorrowful life, willingly accepting their destiny: immortality is both unattainable and undesirable for a human, however attractive it might appear.

It is more logical to read both stories (Tithonus and Ganymede) as examples of warning for Anchises; eternal youth is not accessible for him, and eternal life without ageless is not desirable, so Aphrodite proposes a third, most desirable choice. Aphrodite links the fates of Ganymede and Tithonus to Anchises' situation, then concludes that he (too) will be enfolded by merciless old age:

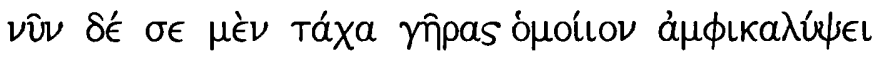

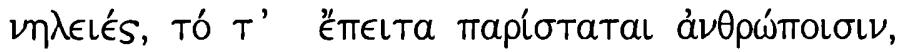

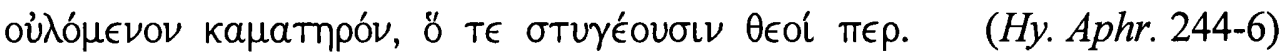

But now you will soon be enveloped by leveling old age, that pitiless companion of every man, baneful, wearisome, and hated even by the gods. (Tr. A. Athanassakis)

since Zeus had the power to make his beloved Ganymede immortal, Aphrodite would have to apply to Zeus on behalf of Anchises, but she cannot do it. 
The message is that life is not eternal, and mortality must be accepted. ${ }^{41}$ This view of life is similar to that of Odysseus (Od. 5.215-20): to live as a mortal in this world even with pain and sorrow; likewise, even the favourites of the gods must struggle and die. ${ }^{42}$ Therefore, the myths of Tithonus and Ganymede are used to explore, as Smith points out, ${ }^{43}$ the value of mortality, and it is through their juxtaposition that we see their complementary, warning aspects.

Exceptional beauty would be the most significant feature shared by all of the three (all members of the same family). As Tithonus and Ganymedes were very beautiful, so is Anchises; he is like an immortal (55). Ganymedes was snatched by Zeus for his beauty, and he has immortality which preserves his beauty ${ }^{44}$ :

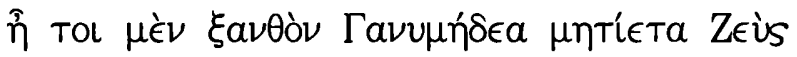

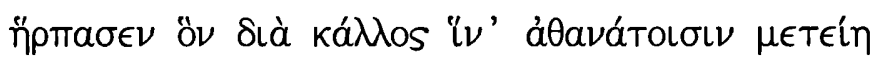

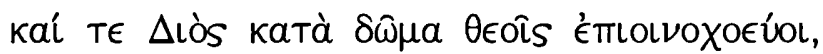

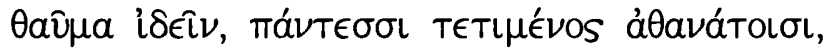

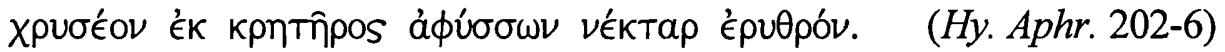 \\ wise Zeus abducted fair-haired Ganymedes \\ for his beauty, to be among the immortals \\ and pour wine for the gods in the house of Zeus, \\ a marvel to look upon, honored by all the gods, \\ as from the golden bowl he draws red nectar. (Tr. A. Athanassakis)
}

\footnotetext{
${ }^{41}$ This story, of course, fits with the myth-tradition in which Anchises remains mortal. I agree with Smith (1981a) 88 that, if this myth is not a fantasy of wish-fulfillment, Anchises' ultimate subjection to death is simply assumed.

${ }^{42}$ For example, Sarpedon, dearest to Zeus of all men, had to die (Il 16, 433, 462-503); Heracles did not escape his doom though Zeus loved him (Il. 18.117-9); Achilles is another case in point.

${ }^{43}$ Smith (1981a) 90.
} 
Ganymedes keeps his physical qualities that make him admired and honoured. And his father Tros, who originally mourned for him, rejoices at his divine honour (216-7). Aphrodite does not say why Anchises cannot get the same treatment with Ganymedes. Probably it makes a difference that Ganymedes was the protégé of Zeus, who can do what he likes. There is also the point that Anchises is already too old: he has had sexual union with Aphrodite, and Ganymedes is not a possible analogy for him. He would not be given by Zeus the privilege that Zeus gave to Ganymedes.

Tithonus, too, was very beautiful when he was young, but he got older and older, and his case shows that Aphrodite, like Eos, has no hope of taking her husband Anchises to Olympus and keeping him young. She makes this clear at 239-40:

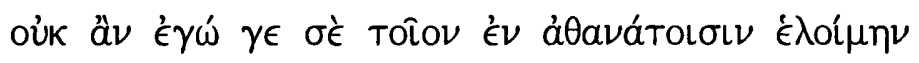

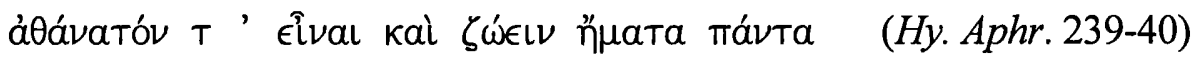

If this were to be your lot among immortals, for you immortality and eternal life. (Tr. A. Athanassakis)

So, the best that Aphrodite can do for Anchises is to get the nymphs to take special care of the child she will give birth to, then bring him to Anchises, and he will take

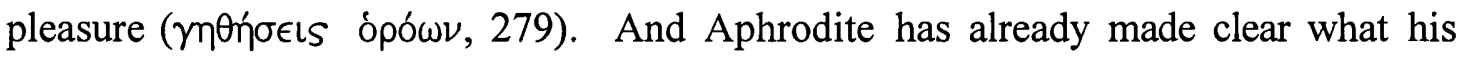
future and that of his descendants will be (196-7; 200-1).

Aphrodite refers again to her sorrow in 243, when she laments for Anchises:

\footnotetext{
${ }^{44}$ Pindar, Ol. 1, 44 briefly mentions that Zeus brought Ganymedes to the Olympus, although there is
} 


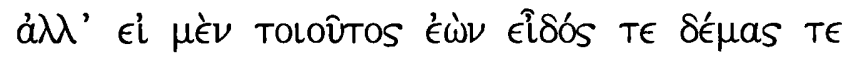

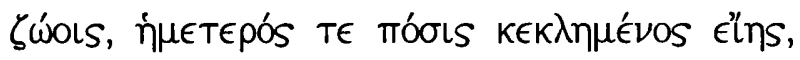

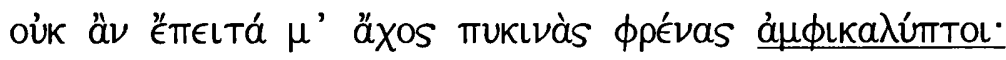

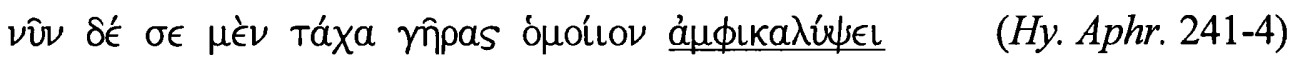

But should you live on such as you now are

in looks and build, and be called my husband,

then no grief would enfold my prudent heart.

But now you will soon be enveloped by leveling old age (Tr. A. Athanassakis)

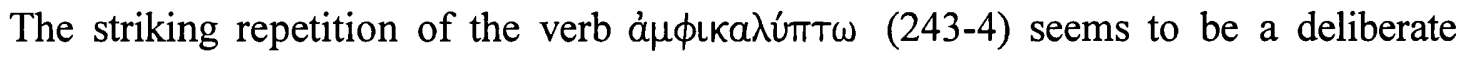
device employed to express Aphrodite's sympathy towards Anchises. ${ }^{45}$ These verses, with a present unfulfilled condition, might be paraphrased thus: 'Anchises will soon be enfolded by old age; then Aphrodite will be enfolded by sorrow.' Aphrodite and Anchises share the same metaphor, in the same space, at the ends of adjoining verses.

However, despite the extent to which Aphrodite sympathises with and pities Anchises, she can turn away from him. Although both are 'enfolded' - Anchises by old age and Aphrodite by äxos - the difference between them is evident. Old age inevitably leads Anchises to death, as is emphasised by $\nu \hat{v} \nu$ $\delta \epsilon$ (244), which denotes the actual state of affairs. In contrast, Aphrodite's ä $\chi 0 s$ is merely a touching sorrow for her.

\footnotetext{
no account of his beauty.

${ }^{45}$ Smith (1981a) 90 offers an interesting interpretation: this repetition supplies the link which bridges the transition: 'the limits of mortality cannot be removed'. I admit that there is a slight gap between 243 and 244, as Smith claims, but I doubt that such verse-end repetition could bridge it.
} 
The overwhelmingly dignified manner of Aphrodite's speech makes Anchises listen and obey; and after restoring order and foretelling the future, Aphrodite departs in a dramatic fashion which again asserts her divinity and shows her superiority - an exit remarkably reminiscent of the deus ex machina of later Euripidean tragedies. Leaving Anchises, Aphrodite retires (or, rather, soars off) from the realm of human suffering into the realm of the gods' blessedness. Men learn, then, that they must go modestly, because 'human endeavour which exceeds the limit is bound to drive them to sorrow and ruin. ${ }^{46}$

At the end of Aphrodite's journey from Cyprus to Ida, she observes and rejoices in the coupling of wild animals (69-74). This scene presents the joyfulness of sexual union, and serves as a prelude to the human experience immediately to follow. ${ }^{47}$ Yet, in the passage describing Anchises' bed (158-160), the skins of these same animals are strewn on it:

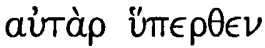

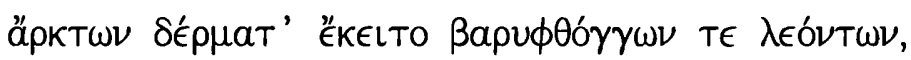

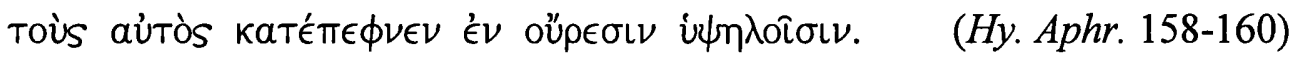 \\ On it were skin of bears and deep-roaring lions, \\ which he himself had killed on the high mountains. (Tr. A. Athanassakis)
}

\footnotetext{
${ }^{46}$ Opstelten (1952) 221.

${ }^{47}$ Parry (1986) 264 points out that, for these beasts, erotic ananke is simple and merely joyful. Sowa (1984) 82 takes this passage as evidence of Aphrodite's cosmic power as a fertility goddess.
} 
The animal skins on Anchises' bed provide, literally, another reinforcement to the theme of the temporary nature of love and life: the animals which joyfully unite share with human beings the same destiny of death. ${ }^{48}$

In the first half of the Hymn, Aphrodite's appearance is godlike despite her disguise as a human; in the latter half, her feelings are human in spite of the fact that she speaks as a goddess. The immortals, even the goddess of love, are involved in the natural cycle of mortal birth and death. This elaborately devised paradox is central to my understanding of the Hymn - and Aphrodite's emotion of alvòv äXos symbolises this paradoxical irony.

\section{The Sorrow of Aphrodite}

Aphrodite's origin is much disputed. There are two perspectives to the question, and each of these offers two further subdivisions: (a) from the view-point of the history of religion (whether Near Eastern or Indo-European); (b) from the view-point of epic tradition (whether she is born from Uranus or from Zeus). However, in spite of such complexities in her origin, Aphrodite's role as love goddess is always predominant in Greek epic.

Since Herodotus $(1.105 ; 131)$, Aphrodite's Near Eastern origin has been widely admitted. ${ }^{49}$ Among scholars, Rose offered the most extreme perspective, suggesting

\footnotetext{
${ }^{48}$ Smith (1981a) 58-9 discusses this passage from another point of view: the animal skin on his bed emphasises Anchises' strength, which helps to prevent him from being seen as a hopelessly weaker and inappropriate partner.
} 
that, 'Aphrodite is, of course, no Greek goddess at all', ${ }^{50}$ and proposed the earliest date of Minoan-Mycenaean times for the original story of Aphrodite and Anchises. Although Rose's opinion is not wholly convincing, many elements of Aphrodite's mythographic construction seem to have been inherited from Near Eastern tradition.

One of the conspicuous features of the Near Eastern Mother Goddess is that her name has changed from time to time, from place to place, while her type has remained constant. ${ }^{51}$ She is Inanna in Sumerian hymns around 3000-2100 BC, Ishtar in Babylonia and Assyria around 1800-600 BC, and Astarte among the Phoenicians of $1000-700$ BC. $^{52}$ These figures are characterised as goddess of love, Queen of Heaven, and, also, as warrior goddess. ${ }^{53}$

Even before Inanna, as far back as the Palaeolithic Age, one finds a nameless goddess universally worshipped around the Mediterranean as the Mighty Mother. ${ }^{54}$ According to Vermaseren, ${ }^{55}$ she is the all-creating Earth Mother; she provides food and drink, being identified with the fertile furrow after ploughing was invented (c. $3000 \mathrm{BC}$ ), and even creates gods and goddesses who rule their own domains and perform their own tasks under Inanna's control; sometimes she is identified with

\footnotetext{
${ }^{49}$ For bibliography on the history of this theory, see Boedeker (1974) 1, n. 7.

${ }^{50}$ Rose (1924) 11.

${ }^{51}$ Frazer (1914) 36.

52 Penglase (1994) $15 \mathrm{ff}$.

${ }^{53}$ James (1959) 184; Burkert (1985) 152-3.

${ }^{54}$ Vermaseren (1977) 13.

${ }^{55}$ Vermaseren (1977) 13-5. Roller (1999) 31-9, in her thorough analysis, places more emphasis on the importance of domestic animals than on female reproductive capacity in the cult of the Anatolian Neolithic period, pointing out (p. 39) that the key symbol of the Phrygian Mother in prehistory is the image of hunting, and of power and strength found in the lion and birds of prey.
} 
mountains, or escorted by animals. Behind the figure of Aphrodite there clearly stand these ancient mother goddesses. ${ }^{56}$

In the Greek Bronze Age, the name of Aphrodite is not found on any of the extant Linear B tablets. The Pylos tablet Tn 316, which lists the names of thirteen deities, does not mention Aphrodite. ${ }^{57}$ The possibilities are: (a) the Mycenaeans did not know Aphrodite; (b) the Mycenaeans knew Aphrodite, but her name happens not to be on the tablets; (c) 'the goddess potnia' (potinija) ${ }^{58}$ is the Mycenaean name of Aphrodite. It is difficult to determine the correct answer, but if we consider the Near Eastern origin of this goddess, and the extent of Near Eastern influence in the eighth century, it appears that possibility (a) - that Aphrodite had not been introduced into Greece by the Mycenaean period - is the most likely solution.

Burkert provides a persuasive discussion of the significance of oriental influence around the eighth century B.C. ${ }^{59}$ As he says, if, in this period, Greek representational style underwent basic modifications by taking up, imitating and

\footnotetext{
${ }^{56}$ All the Greek goddesses, of course, inherited something of the Mighty Mother's features. The goddess of 'the fertile furrow' reminds us of Demeter's 'thrice-ploughed furrow' (Od. 5.127); productivity, especially in child-birth, reminds us of Hera; and Artemis is closely associated with animals.

${ }_{57}$ Cf. Introduction.

${ }^{58}$ The name of potnia can be found almost everywhere the Linear B tablets were found in Pylos, Knossos, and Thebes. The characteristics of potnia in the tablets are (a) she appears often with modifying words, such as 'of upoyo' (PYFr 1225, 1236, PYFn187), 'of newopeo' (PYCc 665), 'of erewijo' (PYVn 48), 'of Labyrinth' (KNGn 707), 'of atana' (KNV52); (b) the word potnia has various kinds of derivatives, such as 'potinijawejo' (PYEp 613, KNDl 933), 'potinijawejojo' (PYEq213); (c) the word potnia always appears in a singular form. Cf. Ventris and Chadwick (1956); Bennett and Olivier (1973); Chadwick (1976).

${ }_{59}$ Burkert (1992) 17 points out that all the sacred sites which came to flourish by the eighth century Delos, Delphi and, above all, Olympia - have produced substantial finds of oriental objects.
} 
transforming the motifs of eastern art, ${ }^{60}$ then myth would also have been subject to oriental influence. ${ }^{61}$

Boedeker suggests an Indo-European origin for Aphrodite ${ }^{62}$ and regards iconographical similarities between Aphrodite and the Great Goddess as overestimated and misinterpreted; she points out the independent but parallel developments of similar features, and suggests that Aphrodite's entry into Greek epic is an extension of expressions originally formulated for the Dawn-goddess. ${ }^{63}$ However, Boedeker's position is difficult to sustain. First, she has to admit the resemblance between Aphrodite and the Great Goddess, and especially between Aphrodite and Astarte. ${ }^{64}$ It is improbable to think of 'independent parallel development' when Greece and the Eastern countries had, as has been demonstrated, so many interrelations. ${ }^{65}$ Second, if Aphrodite, like Zeus, is Indo-European in origin, her name should be etymologically explicable in some other Indo-European language(s), and have a cognate even in Sanskrit (like the name of Zeus). Thus Friedrich finds it necessary to integrate the two opinions, suggesting that Aphrodite is indeed Indo-European in origin, but admitting, too, an oriental influence on her. ${ }^{66}$

Contrary to Friedrich, I trace Aphrodite's origin primarily to the Near East, but see some kind of assimilation to other goddesses, including the Dawn-goddess,

\footnotetext{
${ }^{60}$ Burkert (1992) 14-5.

${ }^{61}$ Frazer (1914) chs. I-III, esp. pp.11-2 suggests that the myth of a goddess and her consort is a major feature of Near Eastern religion. Burkert (1992) 96 notes the parallel between the story of the meeting of Ishtar and Gilgamesh with that of Il. 5.330-431, where Aphrodite is injured by Diomedes.

${ }^{62}$ Boedeker (1974) 5.

${ }^{63}$ Boedeker (1974) 15.

${ }^{64}$ Boedeker (1974) 5.

${ }^{65}$ See also West (1969) 122, 134; West (1997) passim.
} 
after her advent in Greece. ${ }^{67}$ Of course, the problem is that, by the time of the composition of the Homeric and Hesiodic epics, Aphrodite had lost much of the allembracing power of the Great Mother Goddess. ${ }^{68}$ Deprived, notably, of her power in war and politics, she is transformed into the beautiful and refined love-goddess; and Homer himself did much to reduce her power and even to ridicule her.

The Hesiodic story of Aphrodite's birth (Theog. 188-206) stands in opposition to her Homeric genealogy, since both in the Miad and the Odyssey she is always a daughter of Zeus. ${ }^{69}$ Her birth from the sea-foam and the seed of Uranus has a crude, early look, ${ }^{70}$ and this is a good indication of her Near Eastern origin. ${ }^{71}$ In Hesiod, it is emphasised that Aphrodite is a goddess of fertility, with her role in the universe conceived as one of enrichment. ${ }^{72}$ For my particular theme, however, the most important aspect of this story is her birth as a result of generational strife between Uranus and Cronus. ${ }^{73}$ Aphrodite was born at a crucial moment when Uranus, the first cosmic sovereign, was supplanted by the second, in a period not very long after the first cosmic differentiation - the separation of heaven and earth.

\footnotetext{
${ }^{66}$ Friedrich (1978) 81-2.

${ }^{67}$ Càssola (1975) 237-42 also admits Aphrodite's both Semitic and Indo-European elements.

${ }^{68}$ I agree with AHS (1936) 351, who comment that, in the Troad, Aphrodite was probably another form of Cybele; nevertheless, the hymn-writer follows the Homeric conception, and, for Homer, Aphrodite is far removed from Cybele.

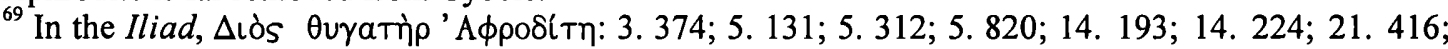

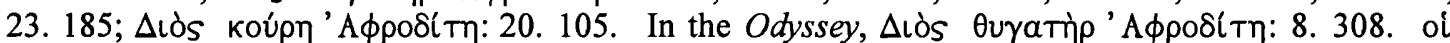

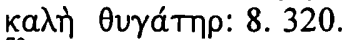

${ }^{70}$ Gantz (1993) 100.

${ }^{71}$ Sale (1961) 508-9; West (1966) 212.

${ }^{72}$ This picture of Aphrodite differs little from Homeric notions. It is difficult to understand why Hesiod derives Aphrodite's origin from Uranus. Sale (1961) 520 suggests that Hesiod combined two kinds of myths: first, Uranus as the father of Aphrodite; and, second, Aphrodite's birth as a consequence of his castration.

${ }^{73}$ Friedrich (1978) 82 suggests that Aphrodite's birth from the genitals is connected with her sexualsensuous functions and contrasts symmetrically with Athene's birth from Zeus' head and her patronage
} 
Her power of love is, thus, of primordial nature, and fundamental to the whole universe. She is the first anthropomorphic deity in the Theogony, and, naturally, is older than all the Olympian gods, including Zeus. Moreover, unlike Cronus' children who were saved by Zeus, Aphrodite owes nothing to him. Her cult title Oủpavía preserves, as West suggests, ${ }^{74}$ the remains of her link with Uranus.

In Homer, Aphrodite's parentage is well established: she is the daughter of Zeus (Il. 3.374, etc., Od. 8.308, 320) and her mother is Dione (Il. 5.370-1). Only here is Dione recorded as the mother of Aphrodite; and we note that the name 'Dione' is a feminised form of 'Zeus'. ${ }^{75}$ The name's derivation might suggest that Zeus has here devised the ambitious trick of giving birth himself, without the need for a female

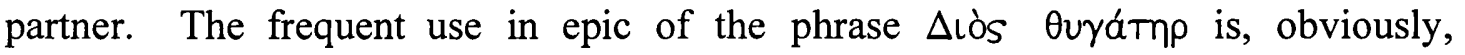
something more than the repetition of a formulaic expression. It not only emphasises Aphrodite's kinship with Zeus, but also, importantly, her subordination to Zeus, ${ }^{76}$ which seems to be Homer's strategy. Whether or not the poet of the Hymn to Aphrodite was acquainted with the Theogony, he nevertheless adapts the Homeric version of Aphrodite's birth, and, following this, tries to place Aphrodite under the control of Zeus.

of wisdom. For oriental influences on Greek succession myth see West (1966) 20-8; Burkert (1992) 90ff.; Janko (1992) ad Iliad 14. 200-7.

${ }^{74}$ West (1966) 212.

${ }^{75}$ Kirk (1990) ad 5. 370-2.

${ }^{76}$ Clay (1989) 200; Gantz (1993) 99. I do not agree with Boedeker (1974) 31 who suggests that her

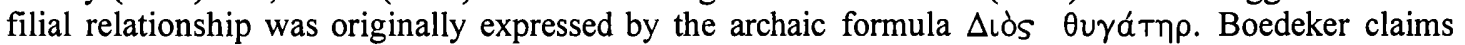
that, when Zeus developed into a highly personalised god, he was no longer identified with the visible sky and, as a result, Aphrodite received her cult title Oủpavia. I suggest that, even though Zeus became highly personalised, he was always recognised as a sky-god. 
This Homeric notion of a degraded Aphrodite is evident not only in her epithet, but also in other passages. For instance, in the famous scene in the Iliad when Aphrodite goes to the battlefield to rescue Aeneas (5.311-430), she is defeated by Diomedes:

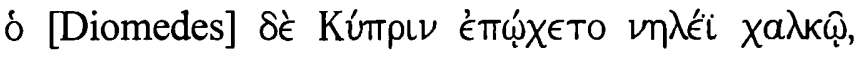

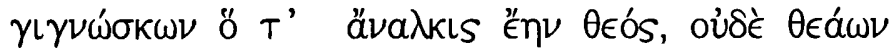

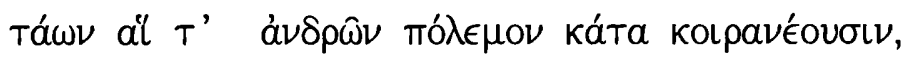

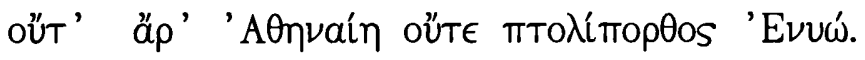

He was pressing after Aphrodite Kypris with the pitiless bronze, knowing that she was a god without strength, and not one of the goddesses who have mastery in men's battles, not Athene or Enyo, the sacker of cities.

(Tr. M. Hammond)

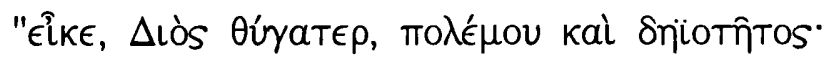

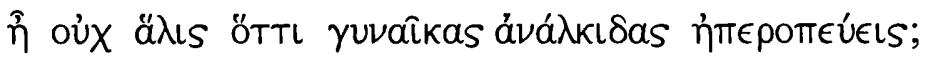

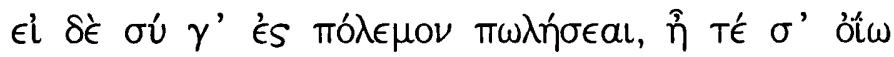

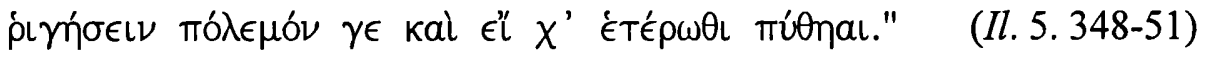

"Away, daughter of Zeus, keep clear of battle and fighting! It is not enough for you to seduce the wits of weak women? If you start frequenting the battle-field, then I think you will come to shudder at war, even hearing of it somewhere else. " (Tr. M. Hammond)

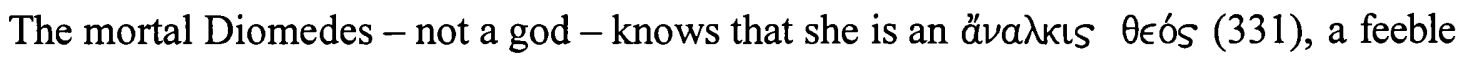
goddess. ${ }^{77}$ Aphrodite's intervention in the war could be a relic of her mythical forebear, the warlike Mother Goddess; however, this Iliadic Aphrodite, defeated by a mortal, is far different from her ancestor. Surprisingly, the arrogant taunt of Diomedes 
(348-51) goes unpunished, and it is in the non-formulaic diction of Diomedes' words ${ }^{78}$ that we see the poet's careful plan - to make us perceive Aphrodite as powerless in the war. This is similar to Hector's words 'the war will be the men's concern' ( defensive position by the fig-tree (6. 429-39). Diomedes repeats the adjective äva入kıs again in 349, this time of women. The implication of Diomedes' insult is that Aphrodite is so feeble that she can only exercise her power over women, who are feeble enough to be cheated. It is natural, therefore, that Zeus prohibits her from attending the war at the conclusion of this episode:

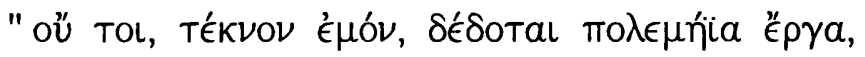

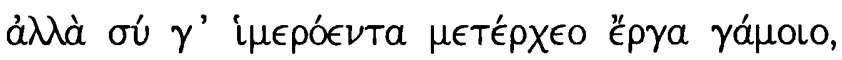

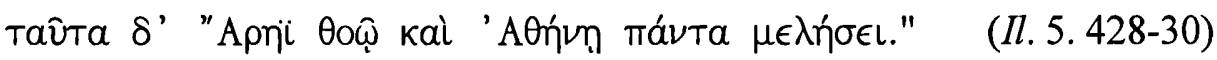

"War's work, my child, is not your province. No, you busy yourself with marriage and the work of love, while all this will be for quick Ares and Athene to see to." (Tr. M. Hammond)

Zeus confines Aphrodite to the 'charming work of marriage' (429). Granted only the power of love, she is thus deprived of the power of war, political power and, most of all, any mighty all-embracing power, which the Great Mother had possessed.

\footnotetext{
${ }^{77}$ Kirk (1990) ad loc. takes $\gamma \iota \gamma \nu \omega ́ \sigma \kappa \omega \nu ~(331)$ both as a recognition of the distinction between god and man, and as a recognition of Aphrodite's feebleness. I put more emphasis on the latter connotation. ${ }^{78}$ Kirk (1990) ad loc.

${ }^{79}$ Also in Aristoph. Lys. 520.
} 
The second example from the Iliad occurs at 14.190 when Hera impresses on us the youthfulness of Aphrodite as a 'younger' goddess. Hera asks her for her love charm, íás:

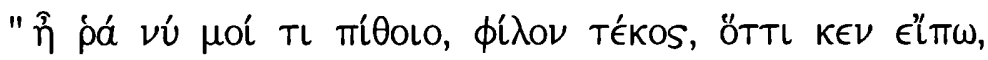

"Now dear child, will you do something for me that I tell you, (Tr. M. Hammond)

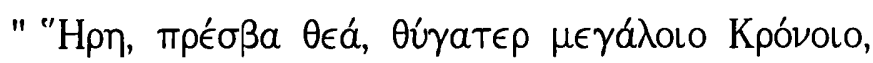

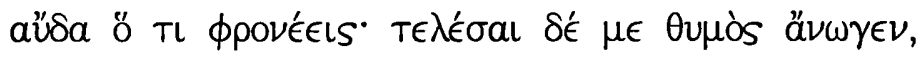

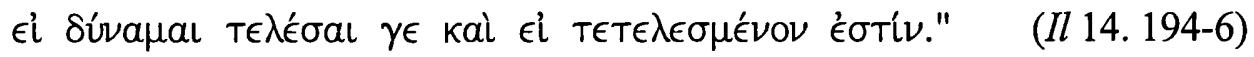

"Hera, queenly goddess, daughter of great Kronos, say what is in your mind. My heart prompts me to do it, if I can and it is something possible. "

(Tr. M. Hammond)

The phrase $\phi i ́ \lambda o \nu$ Tékos (190) is an affectionate address to a younger person, ${ }^{80}$ and

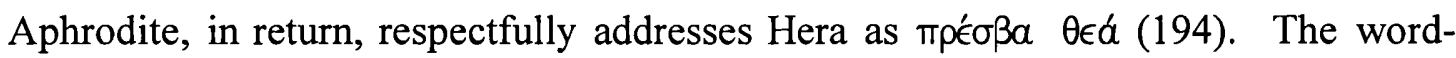
play on $\tau \epsilon \lambda \epsilon^{\prime} \omega$ (195-6) would seem to intensify Aphrodite's offer of help to Hera she wishes heartily for the accomplishment of Hera's plan. ${ }^{81}$ Aphrodite is not only under the control of Zeus, but is also an obedient, younger goddess in relation to Hera.

In the Odyssey, Aphrodite is presented as a shameful goddess in Demodokos' song of her love affair with Ares (Od. 8.266-366). Among this catalogue of indignities in the Homeric poems, there is, however, one arena in which Aphrodite retains power: when she shows her formidable side to Helen (Il. 3.413-20). We see that, although her

\footnotetext{
${ }^{80}$ Janko (1992) ad loc.

${ }^{81}$ I take $\tau \epsilon \tau \epsilon \lambda \epsilon \sigma \mu \epsilon ́ \nu O \nu$ '́ $\sigma \tau\{\nu$ as 'it can be accomplished', following Janko (1992) ad loc.
} 
power is restricted only to the work of love, she is recognised as the mightiest at least in that sphere.

The Theogony offers a remarkable relic of Aphrodite's challenge to the power of Zeus, in its account of the birth and death of Typhon:

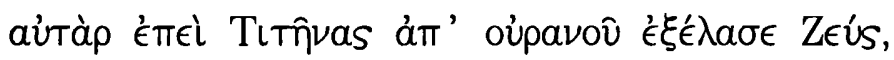

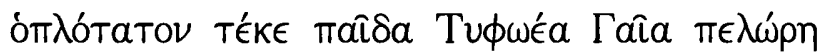

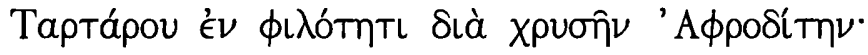
(Theog. 820-2)

Now when Zeus had driven the Titans out of heaven, huge Earth bore as her youngest child Typhoeus, being united in intimacy with Tartarus by golden Aphrodite. (Tr. M.L. West)

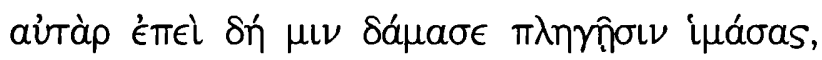

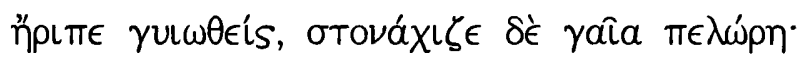
(Theog. 857-8)

When he [Zeus] had overcome him by belabouring him with his blows Typhoeus collapsed crippled, and the huge earth groaned. (Tr. M.L. West)

After the defeat of the Titans, Gaia gives birth to Typhon as the next challenger to Zeus. In this attempt, Gaia is assisted by Aphrodite. ${ }^{82}$ In the Hymn to Apollo (3349), Typhon is the son of Hera, who calls upon Gaia, Uranus and the Titans in Tartarus in her prayer for a child. The versions are united by one significant similarity

\footnotetext{
${ }^{82}$ West (1966) ad loc. suggests that the epithet $\chi \rho \sigma^{\prime} \nu$ is problematic, and that verse 822 may not be genuine like other verses $(962,1005$, etc.) which include this epithet. West's idea is not persuasive enough. The mention of Aphrodite (Theog. 822) could be conventional, meaning nothing more than an ordinary marriage and delivery. But even so, considering the importance of giving birth to Typhon, who is the youngest son of Gaia, and the youngest son is the dangerous challenger of the sovereignty of the universe, like Cronus for Uranus, Zeus for Cronus, only a mention of Aphrodite here would be significant. This would imply, at least, that Aphrodite is on the side of Gaia and Tartarus, that is, the chthonic side, against Zeus.
} 
- a chthonic challenge to Zeus' sovereignty. Just as Hera is helped by Gaia, Uranus and the Titans in the Hymn to Apollo, so Gaia and Tartarus are helped by Aphrodite in the Theogony: all these gods are, to some extent, resistant to Zeus. When Typhon is defeated by Zeus, Gaia groans (Theog. 858), but it is not only Gaia, but also all the other deities in her alliance who must bitterly lament.

The Hymn to Aphrodite follows Homer on Aphrodite's parentage and characterisation, but goes still further: even in the work of love, she is now under the control of Zeus. A most ingenious technique of the hymn-poet is to make Aphrodite fulfil the plan of Zeus by accomplishing her own desire. As Clay remarks, ${ }^{83}$ Zeus utilises Aphrodite's own weapon against her. Zeus reacts not to her power to initiate mischievous love affairs, but to her potential to boast about this power among the gods (47). Zeus, in fact, punishes Aphrodite for the influence that she is able to exert over both himself and the other gods:

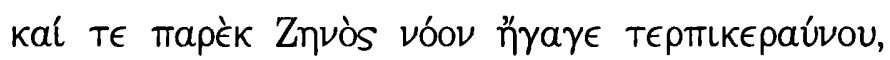

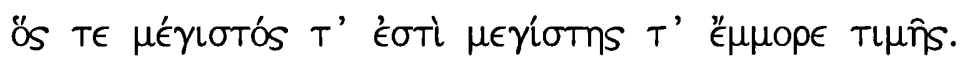

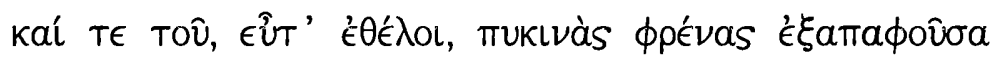

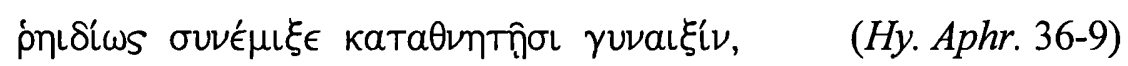

She even led astray the mind of Zeus who delights in thunder and who is the greatest and has the highest honour.

Even his wise mind she tricks when she wills it and easily mates him with mortal women (Tr. A. Athanassakis)

\footnotetext{
${ }^{83}$ Clay (1989) 164.
} 
Note the unconventional juxtaposition in verse 37 - repetition with polysyndeton of Zeus' mightiness with her great influential power.

Her boast, and the punishment for it, are dramatised in an imaginary speech:

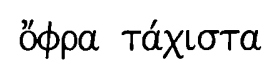

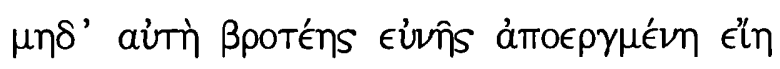

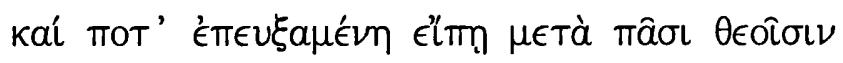

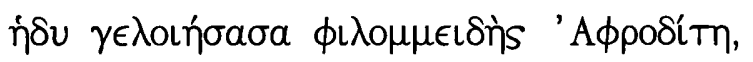

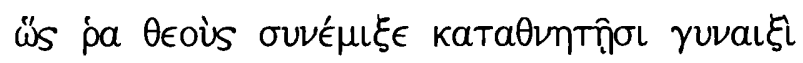

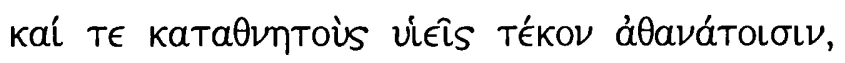

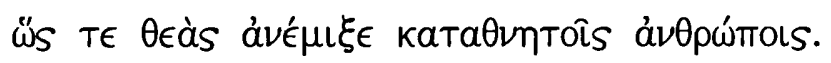

(Hy. Aphr. 46-52)

...his [Zeus] purpose was that even she

might not be kept away from a mortal's bed for long, and that some day the smile-loving goddess might not

laugh sweetly and boast among all the gods

of how she had joined in love gods to mortal women, who bore mortal sons to the deathless gods,

and of how she had paired goddesses with mortal men. (Tr. A. Athanassakis)

This passage (particularly verse 49) well characterises Aphrodite as a powerful and attractive manipulator of love-making between immortals and mortals, and it is because of this dangerous aspect to her character that she must be punished; hereafter, she has to cease to boast.

The same conclusion is presented in Hesiod's Works and Days, but in a quite different way. In the myth of the Heroic Age (among the Five Ages), mortal sons 
from the union of mortals and immortals are called $\eta^{\prime} \mu \hat{\theta} \theta \in \mathrm{Ol} \quad(W . D .160) .{ }^{84}$ They are subject to death but are superior to the men of the present day, i.e. of the poet's own time. ${ }^{85}$ Zeus made the hemitheoi (158), and they were born because men and gods lived on intimate terms in those days. ${ }^{86}$ Hesiod gives no explanation for why the Heroic Age had to end, or why the race of hemitheoi had to perish - he merely states that grim war and dread battle destroyed them (161). According to the Cypria frag. 1, Zeus brought about the war to relieve the earth of overpopulation (Schol. Il. 1.5); Hesiod may, therefore, imply that it was Zeus who made the heroes (158) and destroyed them.

A fragment of Book 5 of the Catalogue of Women (Hes. fr. 204) clearly states that Zeus wanted to separate gods and men:

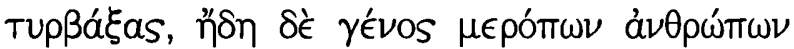

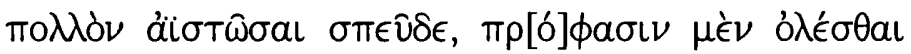

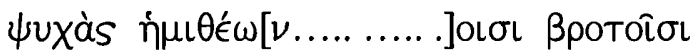

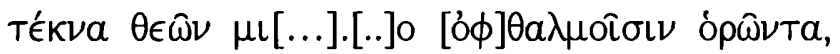

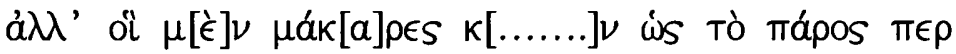

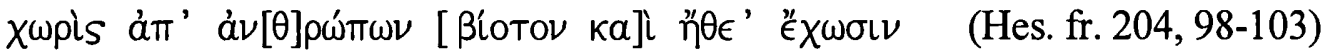 \\ Now he [Zeus] was in a great hurry to obliterate
}

\footnotetext{
${ }^{84}$ West (1978) ad loc. comments that the word refers to their parentage, used when speaking collectively of the men of the heroic age; the word appears only once in the Iliad (12.23), when the heroic age is viewed from the distance of the poet's own time. Scodel (1982b) 40-3 discusses the myth of destruction, pointing out that the theme of destruction by the Deluge affected the myth of the Trojan War, in which Zeus brings about the catastrophe in order to remove the hemitheoi from the world and separate men from gods: this could be to relieve the earth of the burden caused by overpopulation, or to punish impiety.

${ }^{85}$ The race of heroes are 'just and better' than men of the bronze race (W.D. 158) and, by implication, than men of the iron age. See further Thalmann (1984) 103.

${ }^{86}$ Thalmann (1984) 104.
} 
the race of mortal men in order, as he said, that the lives of the half-gods [hemitheoi] should be destroyed... with mortals the children of the gods .... seeing with their eyes,

but the blessed ones ... as in the past

Should have their livelihood and dwellings apart from men

(Tr. W.G. Thalmann)

According to Thalmann's interpretation, the fragment presents the perspective of the gods - not men - on death: Zeus destroyed the hemitheoi once and for all, and prevented the mating of immortals with mortals, because he and the gods could not change the fate of their offspring, and did not want to watch their death. ${ }^{87}$ If Thalmann is correct, this offers quite a sympathetic portrayal of the attitude of Zeus and the gods towards humans.

The basic concept of these texts (the Hymn to Aphrodite, Works and Days, and the fragment of the Catalogue of Women) is the same: once, mortals and immortals enjoyed congress, but at a certain stage it ended, and the race of the hemitheoi perished. However, a remarkable feature of the Hymn to Aphrodite is that this idea is presented as the consequence of Zeus' punishment of Aphrodite. The story-telling is ingenious: the narration of Aphrodite's power as the reason for her punishment is drawn out through the development of the story of her love-making with Anchises.

Aphrodite's power is uniquely different from that of the other gods. The most important feature of her power is that it is grounded in the basic necessity for life to continue procreating; no other gods are privileged with this type of power. For

\footnotetext{
${ }^{87}$ Thalmann (1984) 105-6 also explains that the poet of the fragment imagined, empathetically, what the gods' feelings must be.
} 
example, Athena's craftsmanship and hunting, Artemis' hunting and dancing, Hestia's housekeeping skills, Apollo's music and archery, and Hephaistus' smithing are all types of practical skills or techniques of benefit to humans. But Aphrodite's power of love is characterised by its power over the interrelations of all living creatures which inevitably involves the other gods and goddesses. The mode by which her power operates is problematic: her activity directly attacks other gods and, as a consequence, could pose a challenge to the Olympian order. If her power were beneficial or effective for human beings alone, like the skills of the other gods, Zeus could have afforded to be indifferent to her activities. However, the primordial and interrelational nature of her power could become a serious challenge to Zeus' sovereignty. What Zeus objects is Aphrodite's boast (49-52), but Zeus would know that her indiscipline might cause a difficult crisis. On the surface the text simply narrates Zeus' punishment for her boasting, but if we think why Zeus had to care about her boasting, we might notice Zeus' precaution against her overwhelming power behind the text. Zeus might see the seed of crisis. Aphrodite does not fight with Zeus as the male gods do, but she challenges the power of Zeus in her own unique way. Zeus' punishment implies that Aphrodite's power is too dangerous to be ignored.

Aphrodite's might threatens the power-relations between the Olympian gods. Aphrodite herself says, later in the hymn, that she who was once feared and powerful will now be a figure of shame 'among the immortals' by reason of, we presume, her own display of weakness: 


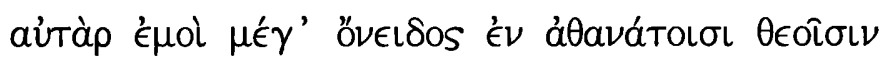

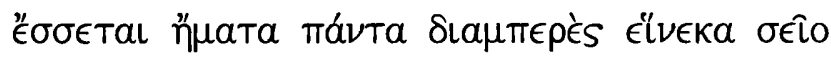

(Hy. Aphr. 247-8)

But great shame shall be mine among the immortal gods

to the end of all time because of you. (Tr. A. Athanassakis)

We arrive back at the moment of Aphrodite's awakening, and the puzzle posed by her apparently contradictory feeling of defeat in victory: she feels shame and bitter

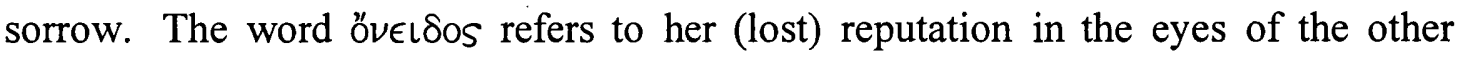
gods. ${ }^{88}$ From this moment forth she can no longer enjoy boasting among the gods of her supreme authority in the works of love.

The phrase ñoi $\gamma \in \lambda o เ n ́ \sigma a \sigma a ~(49)$ nicely encapsulates Aphrodite's sweet, seductive and supercilious nature. Why does Zeus permit such arrogant laughter? Zeus himself can laugh at the other gods, for instance, at Hermes in the Hymn to Hermes (389-90):

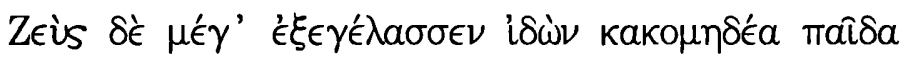

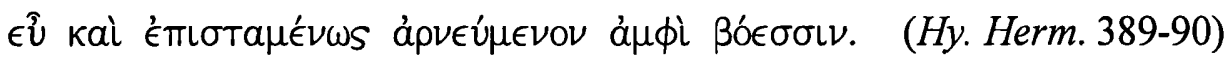

Zeus laughed out loud when he saw the mischievous child denying so well and so adroitly any connection with the cattle. (Tr. A. Athanassakis)

Zeus enjoys Hermes' artful lies, and by this laughter, instantly sorts out the quarrel between Apollo and Hermes. Zeus' laughter has great power, and he rejoices in it -

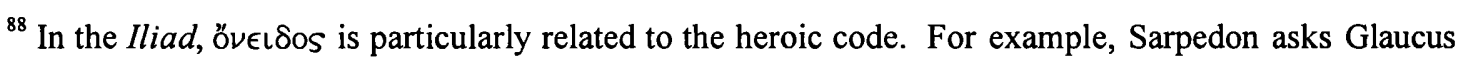
to save his own body (16. 498) and Athene urges Menelaos to save Patroclus' body (17.556); otherwise it will bring reproaches on them.
} 
but is anyone else allowed to share in this power? We see that Zeus' counter-attack against Aphrodite is also an attack on one who would share in divine laughter, ${ }^{89}$ and thus compete haughtily.

Zeus' sovereignty rests on a delicate balance of power. To achieve this, and to bring harmony to the divine domain, Aphrodite must lose her pre-eminence. Her

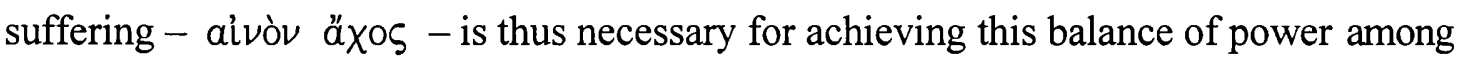
the gods. We note, moreover, that her new emotion is, of course, in clear opposition to her earlier laughter.

Aphrodite can exercise her power even over Zeus, but Zeus can exercise his power over her in exactly the same way. ${ }^{90}$ Thus a balance of power is achieved between the two gods. The poet who celebrates Aphrodite's power nevertheless undermines and restricts this power to achieve a well-balanced relationship between all of the gods in terms of the power they each hold. When we read the hymn in these terms we realise that, in the culminating moment which celebrates Aphrodite's most important aspect, it is rather Zeus' power which becomes the focus of the narrative.

The importance of maintaining cosmic harmony also explains another paradox: Zeus, who, at the beginning, plans to subdue Aphrodite, appears as her defender at

\footnotetext{
${ }^{89}$ Laughter is sometimes used as a tool for manipulating power relations, for example, Iambe in $\mathrm{Hy}$. Dem. (202-4). Although the Greek norm was to laugh at deformity (such as the laughter directed at the crippled Hephaistos at $I l .1 .599$ ), laughter is a powerful tool for control: laughter can unite a group in shared community, for instance, when the gods laugh at Ares and Aphrodite at Od. 8. 326. Bremmer (1997) 13 suggests that humour could be dangerous and had to be limited to strictly defined occasions, and the Greeks were only too aware that laughter could have a very unpleasant side. Halliwell (1991) 281 , in his analysis of $\gamma^{\prime} \hat{\lambda} \omega \mathrm{s}$ in Greek culture, discusses the troops' laughter at Thersites, who is, according to Halliwell, a habitual entertainer and intrinsically deformed figure in his gross ugliness. For laughter at physical faults, see Corbeill (1996) ch.1, esp. 35ff.
} 
the end of the hymn, when she commands Anchises not to reveal that she is Aeneas'

mother. She threatens him with the power of Zeus' thunderbolt:

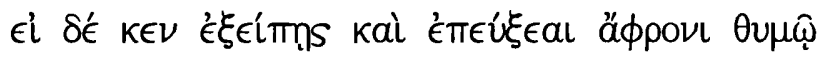

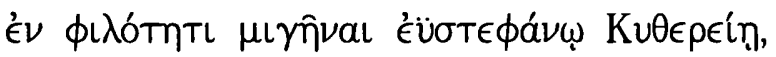

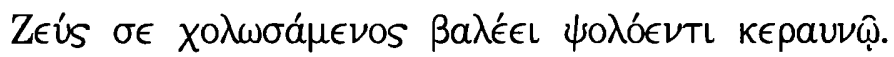

(Hy. Aphr. 286-8)

But if you reveal this and boast with foolish heart

to have mingled in love with fair-wreathed Kythereia, an angry Zeus will smite you with a smoking thunderbolt.

(Tr. A. Athanassakis)

That Zeus, not Aphrodite, will punish him may appear to show their co-operation. In fact, it provides a final, culminating irony, making it appear that Aphrodite, heroine of the hymn, is only such a powerful goddess because almighty Zeus supports her. Other, parallel, readings might suggest that Aphrodite is also not powerful enough to inflict damage on a mortal; or, that she is not allowed to punish mortals and must leave this to Zeus. ${ }^{91}$ If so, the hymn includes another restriction on her powers. If we compare Euripides' Hippolytos, where Aphrodite has overwhelming power to punish Hippolytos and cause him to die at the end of the drama (1347 ff., esp. 1400), then the restriction of Aphrodite's power in this hymn is evident. Aphrodite, it seems, has to pay a huge price for her apparently well-balanced relationship with Zeus.

\footnotetext{
${ }^{90}$ Fränkel (1975) 249-50 interprets this passage as bringing out the principle of compensation, which is, he thinks, an important notion in this hymn, as it is repeated in the story of Ganymede: the anxiety of Tros is recompensed by the honour that he obtained.

${ }^{91}$ Bergren (1989) 7 well defines the complex relation between Zeus, Aphrodite and Anchises, writing that the Hymn attempts to resolve the tension between a cosmos controlled by Aphrodite and a cosmos
} 
Aphrodite's warning to Anchises presupposes that he might boast of his affair with a goddess. The implication is that, for a human male, pairing with a goddess is regarded in a positive light. We know already, from the beginning of the hymn, that this divine-human pairing is viewed negatively on the divine side (45-52), since the affair is itself contrived by Zeus as a punishment for Aphrodite. Ironically, what is sorrowful to a divinity brings honour to a mortal. These two views of the same experience, presented at the beginning and the end of the hymn, function, as I will explain, as a framework.

The long narrative praising the three goddesses at the very beginning (8-32) is one of the most perplexing parts of the hymn. It has been variously interpreted, but not wholly satisfactorily. ${ }^{92}$ I suggest that the problem is best explored from the perspective of power relations and harmony among the Olympian gods.

A list of the three goddess over whom Aphrodite has no influence begins with Athena, who delights in war, battle, and crafts (8-15); next, Artemis, who loves archery, the slaying of wild beasts in the mountains, the lyre and dancing (16-20); and, finally, Hestia, who upholds a great oath to be a maiden, and has her place in the centre of the house (21-32). ${ }^{93}$ As discussed above, the most significant difference between Aphrodite and these three goddesses lies in the jurisdiction of their powers.

controlled by Zeus. The result would be a stable hierarchy in which the immortal male 'tames' the principle of sexuality as an immortal female, who herself tames the mortal male.

92 For example, Smith (1981) 356 comments on the social and institutional side of the three goddesses, as well as on their different attitudes to patronage; Sowa (1984) 53 briefly comments on the word play on É $_{\gamma} \alpha$ in this passage; Clay (1989) 159-62 explains the description of the three goddesses by means of a 'complex set of oppositions'.

93 Thalmann (1984) 20 remarks that this section employs ring composition and is framed by the almost identical lines of 7 and 33 . 
The three goddesses rule their own domains and perform their own tasks, whereas Aphrodite's power dominates existence as a whole: hers is not a particular technique or craft, but a force directing human and divine interrelations. Greek myth is strongly preoccupied with kinship and tensions within the family, ${ }^{94}$ against this background we see that Aphrodite's power is especially dangerous for the equilibrium of the Olympian family. Preventing a direct clash with the other goddesses is vitally important, not only for Zeus, but also for Aphrodite herself. In order to maintain her position within the Olympian family, she needs to get along with the other gods and goddesses, and refrain from violating their powers.

If Aphrodite tried to lure these three goddesses into love affairs, cosmic order could be overthrown (see below) - the last thing that Zeus wishes. Yet, the power of love was the first vital power in the creation of the universe: Hesiod quite rightly puts Eros among the four primordial powers, with Chaos, Gaia and Tartaros (Theog. 120), and almost all of the heavenly bodies, gods and goddesses, are born from the power of love. Aphrodite, as the anthropomorphic equivalent of Eros, holds power of such fundamental and pre-eminent significance that no one can resist. This reminds us of the relationship between the all-embracing Mighty Mother and the other gods, mentioned above. If Zeus is to take over the dominant place held by this Mighty Mother, he must degrade the dangerous power of Aphrodite.

It is important for Aphrodite not to exert her influence on the virgin goddesses. The celebration and praise of these goddesses in this hymn implies that Aphrodite

\footnotetext{
${ }^{94}$ Kirk (1975) 226.
} 
cannot exercise her powers over them. Indeed, the balance of power among the important Olympian goddesses is particularly important with regard to Aphrodite ${ }^{95}$ : in the story of her victory over Athena and Hera in the judgement of Paris, we recall the origin of the Trojan War.

Even from the brief mention of the cause of the Trojan War at Iliad 24. 29-30, the tension between Aphrodite and the two goddess, Athena and Hera, is clearly understood:

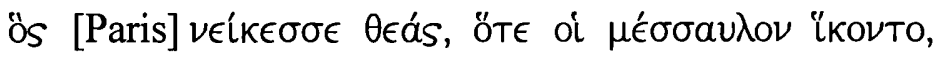

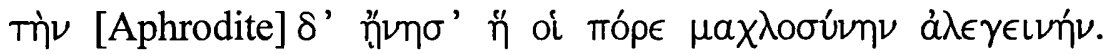

[Paris] had scorned the goddesses when they came to his sheepfold, and gave his choice for the one who offered him dangerous lust. (Tr. M. Hammond)

Paris insulted the other two goddesses and praised Aphrodite. The sharp contrast

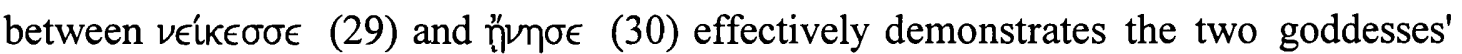
hostility toward Aphrodite as a consequence of Paris' judgement. Richardson ${ }^{96}$ remarks that the word $\mu a \chi \lambda$ ooún implies that what appeared to be a gift really turned out to be disastrous for Paris and for Troy, since the word usually indicates a punishment sent by Aphrodite, rather than a reward. It seems, however, that the unexpected disaster will not only affect Paris and Troy, but also Aphrodite herself.

\footnotetext{
${ }^{95}$ Hestia is sometimes not included among the twelve Olympian gods. Hera gets an honourable mention at 40-44.

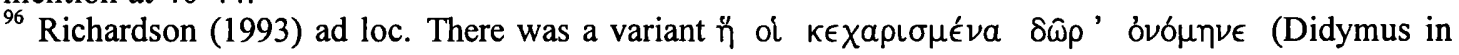
A). 
The judgement of Paris appeared to be a glorification of Aphrodite, but it placed her in the most difficult of situations among her fellow goddesses.

Conscious of this ancient legendary motif, the hymnic poet seems to regard the newly harmonised relation with these goddesses as being a most joyful and welcoming moment for Aphrodite, since the poet puts this account in the very beginning of his hymn. For encomiastic purposes, the new relationship with the other goddesses would seem to the hymnic poet to be significantly effective. The poet describes later in this hymn that this relationship is attained as a consequence of Aphrodite's defeat and experience of bitter sorrow, because, the logic shows, her love affair and the following punishment by Zeus prohibits her from boasting and from imposing her power on the goddesses. In structural terms, the hymn presents us with the result first, and then with the narration of the episode which preceded it. The Hymn to Apollo offers a similar example of this construction: ${ }^{97}$ it begins with the reconciliation scene (2-13) - Apollo, disarmed by Leto, receives nectar from Zeus (10). We then discover that this newly established relationship between Zeus and Apollo is the result of what is subsequently narrated - Apollo's defeat of Typhon (356-9). Similarly, in the Hymn to Aphrodite, the harmonious unity with the goddesses is celebrated first, as of vital importance, then the episode which forms the prerequisite for it is narrated.

A curious tale in the Odyssey (20.67-78) implies the harmonious association of Aphrodite and the other goddesses: 


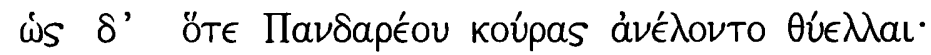

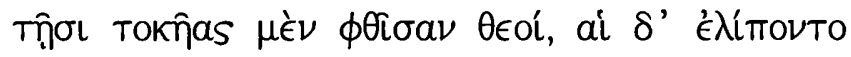

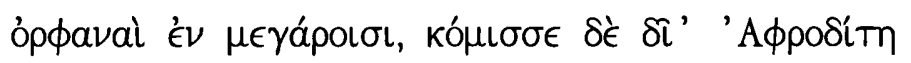

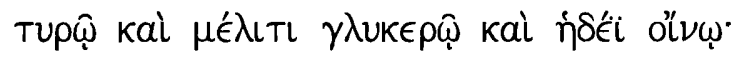

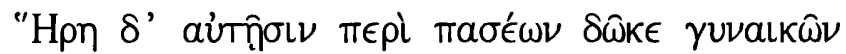

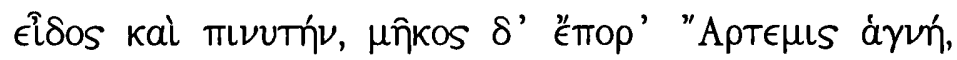

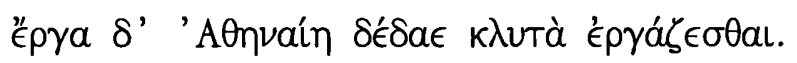

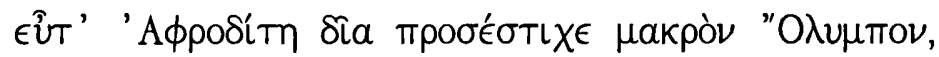

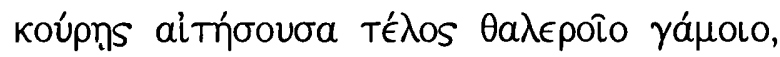

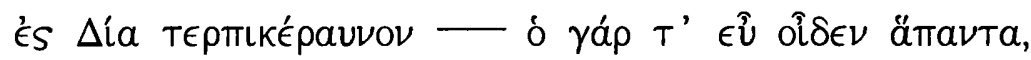

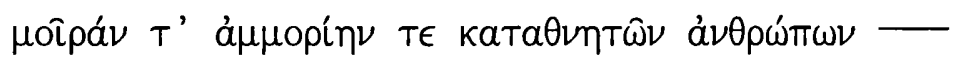

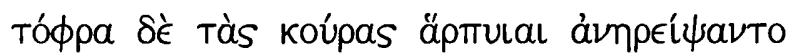

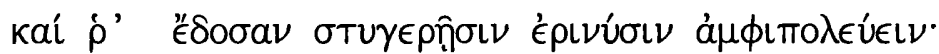

(Od. 20-66-78)

Let it be as when the winds bore off the daughters of Pandareos. The gods long before had slain their parents and the girls were left orphans in their house. But Lady Aphrodite had nurtured them with cheese and sweet honey and pleasant wine; Hera had given them beauty and wisdom beyond all other women; virgin Artemis made them tall, and Athene taught them the making of lovely things. But when Aphrodite went up to high Olympus to entreat Zeus to let these girls attain the moment of happy marriage - because Zeus knows all things perfectly, what is fated and what not fated for mortal men meanwhile the storm-spirits snatched them away and delivered them to the ministrations of the detested furies. (Tr. W. Shewring)

Penelope, having decided to hold the contest of the bow on the following morning, tells this story to illustrate the sudden death (or disappearance) of some girls before their marriage. In the story, Aphrodite raises the orphaned daughters of Pandareos. It is difficult to explain why she would do this, ${ }^{98}$ but likely it is because of her

${ }^{97}$ Cf. Chapter V, Section 4.

${ }^{98}$ Schol. Q.V. ad Od. 20.66 gives the story of Pandareos: Pandareos stole the dog of Zeus on Crete; he kept the dog near Tantalos; when Hermes, sent by Zeus, came to Tantalos, Pandareos fled with his wife and his three daughters to Athens, and then to Sicily; but Zeus found them and killed him and 
specialised connection with pre-nuptial dressing. Aphrodite dresses herself carefully before she meets Anchises in the Hymn to Aphrodite (V: 61-5); and in the Hymn to Aphrodite (VI) she wears garments with a fine well-wrought golden crown, golden earrings, and golden necklaces (5-11); then, importantly, the hymnic poet mentions marriage: 'every one of gods wished to take her home to be his wedded wife' (16-7). In the Cypria too (fr. 4, 5 Allen; Athenaeus 682d-f), she clothes herself in perfumed garments, with crowns of flowers, before she goes to Ida. Aphrodite also helps Pandora become attractive, by shedding grace on her (W.D. 65-6); Pandora is then sent to marry Epimetheus. In the dressing-scene of Hera (Il. 14. 166-223), Zeus' wife completes her cosmetics with Aphrodite's help (Il. 14. 188-223). ${ }^{99}$ Likewise the daughters of Pandareos, with Aphrodite's support, now anticipate their marriage (Od. 20. 73-4), and the story is well-suited to Penelope's current situation, since she has decided to marry the winner of the bow-contest (Od. 19-579).

What is significant in the story of Pandareos' daughters is that the goddesses of the hymn, with the exception of Hestia, appear here too: Aphrodite, Hera, Artemis, and Athena. The powers of the three goddesses are similarly listed - in the form of their presents to the daughters of Pandareos. Hera gives them beauty and wisdom; Artemis, stature; and Athena, skill in handiwork (70-2). While the three goddesses are

his wife. At $O d$. 19.518-24 another story of Pandareos' daughters is told, but the relationship between these stories is unknown.

${ }^{99}$ Janko (1992) ad Il. 14. 187-223 comments that neither Aphrodite's aid nor that of Sleep is essential for Hera's success, but the poet seizes his chance to poke fun at Aphrodite, who is tricked into helping the side that she opposes. Sowa (1984) 75-6 analyses the similarities of the preparation of Hera (Il. 14. 162-86) and Aphrodite (Hy. Aphr. 58-67): both close the door, bathe, are anointed with ambrosial sweet oil, and put on beautiful clothing and ornaments. According to Sowa, all seductions are ultimately performed by Aphrodite herself. 
giving them these benefits, Zeus leaves them to do as they like. However, once Aphrodite asks about their marriage, Zeus intervenes. ${ }^{100}$ In this story, Aphrodite cooperates with the other Olympian goddesses, without infringing on their areas of expertise, just as in the hymn, and Zeus presides over everything, acting to check Aphrodite's power - again, as he does in the hymn. It seems that the Hymn to Aphrodite and the story of Pandareos' daughters in the Odyssey share a constant element, both in the relationship between Aphrodite and the other Olympian goddesses and in the relationship between Aphrodite and Zeus.

Aphrodite, having originated as a Great Goddess in Near Eastern tradition, was eventually incorporated into the Olympian family. In that process she was refined and civilised, but at the same time she had to lose much of her power. ${ }^{101}$ However, for the hymn-poet, the welcoming of Aphrodite by the Olympian gods is the main issue to be praised, even though her power has become restricted. Herodotus quite rightly remarks on this motivation of the poet: 'Homer and Hesiod composed a theogony for the Greeks, gave the gods their titles, assigned them privileges and skills, and described their appearances' $(2.53$, tr. T. Marier). Within the existing hierarchy, every god has to establish his own sphere of influence. The Hymn to Aphrodite celebrates both Aphrodite's properly assigned privileges and her final integration into the Olympian order.

\footnotetext{
${ }^{100}$ I take v. 76 as 'what is fated and what is not fated', following Russo (1992) ad loc.

${ }^{101}$ I agree with Clay (1989) 155, n. 7, who notes that restriction of the power of female goddesses is entirely in keeping with the patriarchal Olympian orientation of the Homeric Hymns.
} 
The gods assemble on Olympus as a unity. The effect of this device is to compare the community of gods with the human world as a whole. ${ }^{102}$ The festivals in honour of the gods also celebrate civic life, where the solidarity of the community is of major importance. The hymns would naturally be expected to celebrate the harmonious divine world, and to affirm the value of community. The Hymn to Aphrodite contributes effectively to this purpose, by representing solidarity in Olympian society.

The value of this hymn, however, lies not only in this theme of social and political solidarity. The hymn deals with profound and universal problems of mortality, love and death, by presenting us with a dualistic picture of Aphrodite's greatness and insignificance, in much the same way as we look at the heroes of epic, where both the greatness and the insignificance of human life is narrated. ${ }^{103}$ The hymn demonstrates that, like the human heroes, gods, too, have complex natures: they have sublime knowledge and power coupled with apparently all too human weaknesses.

\footnotetext{
${ }^{102}$ Griffin (1980) 186.

${ }^{103}$ Griffin (1980) 203.
} 


\section{Conclusion}

I have proposed new ways of interpreting the texts under discussion, and have offered suggestions for further, innovative means of access to these texts. As I expressed in the Introduction, my approaches and conclusions articulate but one coherent hermeneusis amid a wealth of alternatives. My particular analysis does, however, offer a positive contribution to a deeper understanding of this material.

I emphasised the function of allusion in the narratives under discussion. In particular, I highlighted how difficult it is to distinguish between poetic allusion and poetic innovation or invention. One specific problem is that, almost certainly, the two concepts can co-exist: that is, the existence of one does not negate the existence of the other. The poet can be considered to be innovating in his individual selection and orchestration of allusions and intertexts -- in the details and story variants to which he refers. But, as I discussed, the designation of poetic choices as 'inventions' -- because of their improbability, inconsistency or lack of other parallel account -- can restrict a more sensitive reading of the power and meaning of these deliberate poetic selections. As Buxton points out, 'in view of the patchy nature of our evidence, it is unwise to be so restrictive.' $\mathrm{He}$ continues that, 'Greek mythical tradition was dynamic: given the right circumstances an innovation would achieve currency, only to lose it later if other versions were found more persuasive.'

Beneath the extant epic tradition, we can distinguish an enormous variety of versions of epic and mythic stories on which the poet could draw: the possibilities for allusion -- and innovation -- are extensive. It has been a central concern in this thesis 
to delve below this extant epic tradition in search of these alternative stories to which the poets alluded, or which resonated in their words, ${ }^{2}$ and to seek more profound implications in these texts than has previously been considered.

We should not underestimate the sophistication of the ancient audience. Let us consider the example offered by Aristophanes' comedies: it seems that the audience was attuned to a great many of the story-variants, and remembered and appreciated the various verses of the tragedies re-presented and parodied by the comic poet. Like the audiences of these comedies, the audiences of early epic must similarly have possessed considerable knowledge of -- and openness towards -- the myths and stories which had been passed down to them. It is not too much to presume that, when they listened to these epic tales, they were sensitive to the poets' hints and allusions to other stories, and appreciated the poet's allusive skills and techniques.

Recovering these allusions is difficult, but we should attempt to trace suspected concealed meanings in order to facilitate our access to the ancient reception of these texts. Only by perceiving the fuller force of the poets' allusive skills can we fully appreciate the multifarious nuances of these narratives. Recognising the underlying 'hidden logic' represented by these poetic allusions broadens our understanding of the scale of the stories and strengthens the impressiveness of the episodes. It is for this reason that I have exploited the potential offered by 'harder' readings of the function and consequences of poetic allusion.

\footnotetext{
${ }^{1}$ Buxton (1994) 16.

${ }^{2}$ Lang (1983) discusses how 'reverberation' would have operated in the Iliad, and specifically she points out at p.158 that divine binding in the stories of book 1 and 5 was an echo or reverberation from heroic epic. Cf. Introduction p.20 above.
} 
In following these allusive threads, I have concentrated on one major theme, namely the challenges to the power of Zeus. My particular interest was suggested by the persistence of preservations of these stories by the ancient Greeks. One reason for their preservation, I suggest, is the audiences' fondness for a particular theme: ${ }^{3}$ that is, the concept that equilibrium is obtained only after the overcoming of dangerous enemies; further, there was an interest in the elaboration of the ingenious means and devices by which a conqueror, exploiting both intellectual and physical power, obtained final victory. This is a theme observed in the Odyssey: after narrating Odysseus' exciting adventures, the final twelve books narrate for us, at length, how Odysseus successfully regained his kingship at Ithaca. Similarly, Zeus' lengthy progress to victory was apparently of tremendous attraction to the ancient audience. The theme is preserved, and recurs in manifold forms, both explicitly narrated and implicitly alluded or implied in early epic. By following these allusive traces, we gain a broader understanding of the 'logic' of Zeus' victory. In turn, as I have elaborated, we can, again, share something of the amusement and joy with which the ancient audience beheld Zeus' cunning victories.

In conclusion, let us consider Kirk's statement on the nature of myth: ${ }^{4}$

Myths, therefore, are often multifunctional, and consequently different hearers can value a myth for different reasons. Like any tale, a myth may have different emphasis or levels of meaning; if these are especially abstract, then the area of ambivalence is increased still further. The consequence is that analysis of a myth should not stop when one particular theoretical explanation

\footnotetext{
${ }^{3}$ Many of the early stories are influenced by Near Eastern traditions, as I noted in the Introduction. Unfortunately, these Oriental stories are, in general terms, preserved in fragmentary form. Their survival and transmission is both incidental and accidental, and much affected by the political history of the surrounding lands and countries. But we can say that without some will to preserve the texts, they would never have survived.
} 
had been applied and found productive. Other kinds of explanation may also be valid.

Myth presents us with an innumerable multiplicity of explanations and such attractiveness and allusiveness as to induce us to form manifold interpretations of the same basic material/s. Myth, we find, is powerful: all ages and all peoples have been fascinated by the potential offered by myth to provide complex reflections of human activity -- or, in other words, a crystallisation of the human soul.

\footnotetext{
${ }^{4}$ Kirk (1974) 39.
} 
Abbreviations

AHS

The Homeric Hymns, eds. T.W. Allen, W.R. Halliday and E.E.

Sikes, $2^{\text {nd }}$ edition, Oxford, 1936.

Allen

The Fragment of Mimnermus: Text and Commentary, Stuttgart, 1933.

ANET

Ancient Near Eastern Texts Relating to the Old Testament, ed. J.

Pritchard, $2^{\text {nd }}$ edition, Princeton, 1955.

D.

Anthologia Lyrica Graeca, ed. E. Diehl, Leipzig, 1942.

D.-K.

Die Fragmente der Vorsokratiker, eds. H. Diels and W.

Krantz, 3 vols., $6^{\text {th }}$ edition, Zürich, 1951-1952.

Drachmann

Scholia Vetera in Pindari Carmina, ed. A.B. Drachmann, vols. 1-3, Leipzig, 1903-1927.; repr. Stuttgart-Leipzig 1997.

Dindorf

Scholia Graeca in Homeri Odysseam, ed. W. Dindorf, vols. 12, Oxford, 1855.

$E G F$

Epicorum Graecorum Fragmenta, ed. M. Davies, Göttingen, 1988.

Erbse

Scholia Graeca in Homeri Iliadem, ed. H. Erbse, vols. 1-6, Berlin, 1969-1983.

G.-P.

The Greek Anthology: Hellenistic Epigrams, eds. A.S.F. Gow and D.L. Page, vols. 1-2, Cambridge, 1965.

Gallavotti Inscriptiones Pyliae ad Mycenaeam Aetatem Pertinentes, eds. C. Gallavotti, E.L. Bennet and M. Lang, Rome, 1961.

L.-P. Supplementum Hellenisticum, eds. H. Lloyd-Jones and P. Parsons, Berlin, 1983.

$L I M C$ Lexicon Iconographicum Mythologiae Classicae, eds. L. Kahil et alii, Zurich and Munich, 1981- 
M.-W. Fragmenta Hesiodea, eds. R. Merkelbach and M.L. West, Oxford, 1967

PMG Poetae Melici Graeci, ed. D.L. Page, Oxford, 1962.

PMGF Poetarum Melicorum Graecorum Fragmenta, ed. M. Davies, vol. 1, Oxford, 1991.

P.Köln Kölner Papyri, eds. B. Kramer, M. Erler, D. Hagedorn and R. Hübner, vol. 3, Opladen, 1978.

P.Oxy. Oxyrhynchus Papyri, eds. B.P. Grenfell, A.S. Hunt et alii, London, 1898-

S.-M. Pindari Carmina cum Fragmentis, eds. B. Snell and H. Maehler, Leipzig, 1987-1989.

van Thiel D-Scholia to Homer, ed. H. van Thiel, www.uni-koeln.de/phil$\mathrm{fk} / \mathrm{ifa} /$ vanthiel

W. Iambi et Elegi Graeci, ed. M.L. West, vols. 1-2, Oxford, 19711972.

West Homerus: Ilias, ed. M.L. West, vols. 1-2, München-Leipzig, 1998-2000.

Other abbreviations follow L'Année philologique, Paris. 


\section{Bibliography}

Adkins, Arthur W. H., Merit and Responsibility: A Study in Greek Values, Oxford: Clarendon Press, 1960.

Alden, Maureen, Homer Beside Himself: Para-Narratives in the Iliad, Oxford: Oxford University Press, 2000.

Allen, T.W. ed., Homeri Opera, V, Oxford: Clarendon Press, 1912.

Allen, T.W. and Sikes, E.E., The Homeric Hymns, London: Macmillan, 1904.

Allen, T.W., Halliday, W.R., and Sikes, E.E., The Homeric Hymns, $2^{\text {nd }}$ ed., Oxford: Clarendon Press, 1936.

Ameis, K., Hentze, C., and Cauer, P., Homers Odyssee, 2.2, Gesang 19-24, Leipzig: Teubner, 1925.

Angier, [Sowa] Cora, "Verbal Patterns in Hesiod's Theogony", HSCP 68 (1964), 329344.

Arthur, Marilyn B., "The Dream of a World Without Woman: Poetics and the Circles of Order in the Theogony Prooemium", Arethusa 16 (1983), 97-116.

Austin, Norman, "The Function of Digressions in the Iliad", GRBS 7 (1966), 295-312.

------, Meaning and Being in Myth, University Park: The Pennsylvania State University Press, 1989.

Beekes, Robert S. P., Comparative Indo-European Linguistics: An Introduction, Amsterdam: J.Benjamins Pub., 1995.

Bennett, E.L. ed., The Pylos Tablets: Texts of the Inscriptions Found 1939-1954, Princeton: Princeton University Press, 1955.

Bennett, E.L., Chadwick, J. and Ventris, M. eds., The Knossos Tablets, $2^{\text {nd }}$ ed., London: University of London, Institute of Classical Studies, 1959.

Bennett, Emmett L. and Olivier, Jean-Pierre, The Pylos Tablets Transcribed, Rome: Edizioni dell'Ateneo, 1973-1976. 
Bergren, Ann L.T., "The Homeric Hymn to Aphrodite: Tradition, Rhetoric and Blame", CA 8 (1989), 1-41.

Blundell, Mary W., Helping Friends and Harming Enemies: A study in Sophocles and Greek Ethics, Cambridge: Cambridge University Press, 1989.

Boedeker, Deborah Dickmann, Aphrodite's Entry into Greek Epic, Leiden: E.J. Brill, 1974.

Braswell, Bruce K., "Mythological Innovation in the Iliad," CQ 21 (1971), 16-26.

Bremmer, Jan, "Jokes, Jokers and Jokebooks in Ancient Greek Culture", in J. Bremmer and H. Roodenburg, eds., A Cultural History of Humour: From Antiquity to the Present Day, Cambridge: Polity Press, 1997.

------, "An Enigmatic Indo-European Rite: Paederasty", Arethusa 13 (1980), 279-298.

Brown, Norman O., "The Birth of Athena", TAPA 83 (1952), 130-143.

Buck, Carl Darling, Comparative Grammar of Greek and Latin, Chicago: The University of Chicago Press, 1933.

Burkert, Walter, "Kynaithos, Polycrates, and the Homeric Hymn to Apollo", Arktouros, Hellenic Studies presented to B.M.W. Knox, Berlin: Walter de Gruyter, 1979, 53-62.

-------, Greek Religion: Archaic and Classical, tr. John Raffan, Oxford: Blackwell, 1985. (Originally published as Griechische Religion der archaischen und klassischen Epoche, Stuttgart, 1977).

------, The Orientalizing Revolution: Near Eastern Influence on Greek Culture in the Early Archaic Age, tr. M.E. Pinder and W. Burkert, Cambridge, Mass: Harvard University Press, 1992. (Originally published as Die orientalisierende Epoche in der griechischen Religion und Literatur, Heidelberg, 1984).

-------, Savage Energies: Lessons of Myth and Ritual in Ancient Greece, tr. Peter Bing, Chicago: The University of Chicago press, 2001. (Originally published as Wilder Ursprung: Opferritual und Mythos bei der Griechen, Berlin, 1990).

Buxton, Richard, Imaginary Greece: The Context of Mythology, Cambridge: Cambridge University Press, 1994. 
Caldwell, Richard, The Origin of the Gods: A Psychoanalytic Study of Greek Theogonic Myth, Oxford: Oxford University Press, 1989.

Campbell, Joseph, The Masks of God: Occidental Mythology, New York: The Viking Press, 1964.

Càssola, di, Filippo, Inni Omerici, Milan: Fondazione Lorenzo Vella, 1975.

Chadwick, John, The Mycenaean World, Cambridge: Cambridge University Press, 1976.

Chantraine, Pierre, Grammaire homérique, Tome II: Syntaxe, Paris: Librairie C. Klincksieck, 1963.

--.---. Dictionnaire étymologique de la langue grecque, tome 1-2, Paris: Klincksieck, 1972.

Clay, Jenny Strauss, The Politics of Olympus, Form and Meaning in the Major Homeric Hymns, Princeton: Princeton University Press, 1989.

Cook, Arthur Bernard, Zeus: A Study in Ancient Religion, vol. I-III, Cambridge: Cambridge University Press, 1914-1940.

Corbeill, Anthony, Controlling Laughter: Political Humor in the Late Roman Republic, Princeton: Princeton University Press, 1996.

Cornford, F.M., Principium Sapientiae: The Origins of Greek Philosophical Thought, Cambridge: Cambridge University Press, 1952.

Craik, Elizabeth M., The Dorian Aegean, London: Routledge, 1980.

Davidson, Olga M., "Indo-European Dimensions of Heracles in the Iliad 19.95 - 133", Arethusa 13 (1980) 197-202.

Dawe, R.D., The Odyssey: Translation and Analysis, Lewes, Sussex: The Book Guild, 1993.

De Jong, Irene, A Narratological Commentary on the Odyssey, Cambridge: Cambridge University Press, 2001.

De Ste Croix, G.E.M., The Class Struggle in the Ancient World, London: Duckworth, 1981. 
Denniston, J.D., The Greek Particles, $2^{\text {nd }}$ edn, Oxford: Clarendon Press, 1954.

Détienne, Marcel \& Vernant, Jean-Pierre, Cunning Intelligence in Greek Culture and Society, tr. Janet Lloyd, Sussex: The Harvester Press, 1978. (Originally published under the title of Les Ruses de l'intelligence: la Mètis des grecs, Paris, 1974)

Devereux, G., "The Self-Blinding of Oidipous in Sophocles' Oidipous Tyrannos", JHS 93 (1973), 36-49.

Dietrich, B. C., Death, Fate and the Gods: The development of a religious idea in Greek popular belief and in Homer, London: the Athlone Press, 1965.

Dindorf, G., Scholia Graeca in Homeri Iliadem, Tomus I \& II, Oxford: Clarendon Press, 1875.

Dodds, E. R., The Greeks and the Irrational, Berkeley: University of California Press, 1951.

Drerup, Engelbert, "Der Homersche Apollonhymnos: Eine Methologische Studie", Mnemosyne 3 ser. 5 (1937), 81-134.

DuBois, Page, "Eros and the Woman", Ramus 21 (1992), 97-114.

Dumézil, Georges, Mythe et épopée, Paris: Gallimard, 1968.

Edwards, Mark W., Homer, Poet of the Iliad, Baltimore: The Johns Hopkins University Press, 1987.

------, The Iliad: A Commentary, Vol. V: books 17 - 20, Cambridge: Cambridge University Press, 1991.

Eliade, Mircea, Images and Symbols: Studies in Religious Symbolism, tr. Philip Mairet, London: Harvill Press, 1961. (Originally published under the title of Images et Symboles, Paris, 1952).

Erbse, Hartmut, Untersuchungen zur Funktion der Götter im homerischen Epos, Berlin: Walter de Gruyter, 1986.

Fenik, Bernard C., ed., Homer, Tradition and Invention, Leiden: E.J. Brill, 1978.

Finkelberg, Margalit, "Royal Succession in Heroic Greece", CQ 41 (1991), 303-316. 
Fontenrose, Joseph, Python: A Study of Delphic Myth and its Origins, Berkeley and Los Angeles: University of California Press, 1959.

Förstel, Karl, Untersuchungen zum homerischen Apollonhymnos, Bochum: Studienverlag Brockmeyer, 1979.

Fowler, R. L., "AI - in Early Greek Language and Myth", Phoenix 42 (1988), 95-113.

Fränkel, H., Early Greek Poetry and Philosophy, tr. M. Hadas and J. Willis, Oxford: Blackwell, 1975. (Originally published as Dichtung und Philosophie des frühen Griechentums, Münich, 1962).

Frazer, J. G., The Golden Bough: A Study in Magic and Religion, Part IV, Adonis, Attis, Osiris, vol. 1, $3^{\text {rd }}$ ed., London: Macmillan, 1914.

Friedrich, Paul, The Meaning of Aphrodite, Chicago: The University of Chicago Press, 1978.

Gallavotti, C., Inscriptiones Pyliae ad Mycenaeam Aetatem Pertinentes, Rome: Edizioni dell'Ateneo, 1961

Gantz, Timothy, Early Greek Myth: A Guide to Literary and Artistic Sources, Baltimore: The Johns Hopkins University Press, 1993.

Gemoll, A., Die homerischen Hymnen, Leipzig: Teubner, 1886.

Gould, J., "Hiketeia", JHS 93 (1973), 74-103.

Graf, Fritz, Greek Mythology, tr. Thomas Marier, Baltimore: The Johns Hopkins University Press, 1993. (Originally published as Griechische Mythologie, 1987).

Green, Peter, The Argonautika, Apollonios Rhodios, Berkeley and Los Angeles: University of California Press, 1997.

Griffin, Jasper, "The Epic Cycle and the Uniqueness of Homer", JHS 97 (1977) 3953.

------, Homer on Life and Death, Oxford: Clarendon Press, 1980.

-------, The Mirror of Myth, Classical Theme and Variations, London: Faber and Faber, 1986.

------, Homer: Iliad Book Nine, Oxford: Clarendon Press, 1995. 
Griffith, Mark, "Contest and Contradiction in Early Greek Poetry", in M. Griffith and D. J. Mastronarde eds., Cabinet of the Muses: Essays on Classical and Comparative Literature in Honor of Thomas G. Rosenmeyer, Atlanta: Scholars Press, 1990, 185207.

Hainsworth, Bryan, The Iliad: A Commentary, Vol. III: books 9-21, Cambridge: Cambridge University Press, 1993.

Halliwell, Stephen, "The Uses of Laughter in Greek Culture", CQ 41 (1991) 279-296.

Harrison, Jane Ellen, Prolegomena to the Study of Greek Religion, Cambridge: Cambridge University Press, 1903.

Hayman, Henry, The Odyssey of Homer, Vol. II, Books VII-XII, London: David Nutt, 1873.

------, The Odyssey of Homer, vol. III: books XIII to XXIV, London: David Nutt, 1882.

Heidel, Alexander, The Babylonian Genesis: The Story of the Creation, $2^{\text {nd }}$ ed., Chicago: The University of Chicago Press, 1951.

Heitsch, E., Aphroditehymnos, Aeneis und Homer, Hypomnemata 15, Göttingen: Vandenhoeck \& Rupprecht, 1965.

Heubeck, A., West, S., and Hainsworth, J.B., A Commentary on Homer's Odyssey, vol. I, Books I-VIII, Oxford: Clarendon Press, 1988.

Heubeck, Alfred and Hoekstra, Arie, A Commentary on Homer's Odyssey, vol. II, Books IX - XVI, Oxford: Clarendon Press, 1989.

Hoekstra, A., The Sub-epic Stage of the Formulaic Tradition: Studies in the Homeric Hymn to Apollo, to Aphrodite and to Demeter, Amsterdam: North Holland Publishing Company, 1969.

Holoka, James P., "Looking Darkly (YMO $\Delta \mathrm{PA} I \Delta \Omega \mathrm{N}$ ): Reflection on Status and Decorum in Homer", TAPA 113 (1983), 1-16.

Hunter, Richard, Apollonius of Rhodes: Jason and the Golden Fleece (Argonautica), Oxford: Clarendon Press, 1993. 
Huxley, G. L., Greek Epic Poetry: From Eumelos to Panyassis, London: Faber and Faber, 1969.

Jacoby, Felix, Hesiodi Carmina, Berlin: Weidmann, 1930.

James, E.O., The Cult of the Mother Goddess: An Archaeological Documentary Study, London: Thames and Hudson, 1959.

Janko, Richard, "Equivalent Formulae in the Greek Epos", Mnemosyne 34 (1981a) 251-264.

-------, Review of P. Smith, Nursling of Mortality, CR 31 (1981b), 285-286.

------, Homer, Hesiod and the Hymns: Diachronic Development in Epic Diction, Cambridge: Cambridge University Press, 1982.

------, "The Shield of Heracles and the Legend of Cycnus", CQ 36 (1986), 38-59.

-------, The Iliad: A Commentary, Vol. IV: books 13-16, Cambridge: Cambridge University Press, 1992.

Jeanmaire, H., "La Naissance d'Athéna et la royauté magique de Zeus", Revue Archéologique 48 (1956), 12-39.

Jebb, R.C., Sophocles, The Plays and Fragments, Part III, Cambridge: Cambridge University Press, 1896.

Kakrides, J.P., "TI $\Theta \Omega$ NO乏", Wiener Studien 48 (1930), 25-38.

Kamerbeek, J. C., The Play of Sophocles, Part I, Leiden: E.J. Brill, 1963.

Kauer, Sigrid, Die Geburt der Athena im altgriechischen Epos, Würzburg: Verlag Konrad Triltsch, 1959.

Kim, Jinys, The Pity of Achilles: Oral Style and the Unity of the Iliad, Oxford: Rowman \& Littlefield, 2000.

King, Helen, "Tithonos and the Tettix", Arethusa 19 (1986), 15-35.

Kirk, G. S., The Songs of Homer, Cambridge: Cambridge University Press, 1962.

------, Myth; Its Meaning and Function in Ancient and Other Cultures, Cambridge: Cambridge University Press, 1970. 
------, "The Iliad: The Style of Books 5 and 6", in T. Winnifrith et al., Aspects of the Epic, London: Macmillan, 1983.

-------, The Iliad: A Commentary, Vol. I: books 1-4, Cambridge: Cambridge University Press, 1985.

------, The Iliad: A Commentary, Vol. II: books 5-8, Cambridge: Cambridge University Press, 1990.

Kramer, B., Erler, M., Hagerdorn, D., und Hübner, R., Kölner Papyri, Band 3, Papyrologica Coloniensia Vol. VII, Opladen: Westdeutscher Verlag, 1978.

Kuch, Heinrich, "Thetis und die Fesselung des Zeus", Rheinisches Museum für Philologie 136 (1993), 203-9.

Lang, Mabel L., "Reverberation and Mythology in the Iliad", ed. C.A. Rubino and C. Shelmerdine, Approaches to Homer, Austin: University of Texas Press, 1983, 140164.

Leaf, Walter, The Iliad, vol. I - II, $2^{\text {nd }}$ edn, London, 1900-2.

Lesher, J. H., Xenophanes of Colophon: Fragments, Toronto: University of Toronto Press, 1992.

Lesky, A., tr. C. Heer and J. Willis, A History of Greek Literature, London: Duckworth, 1966 (1963).

Lloyd-Jones, Hugh, The Eumenides by Aeschylus, Englewood Cliffs, N.J.: PrenticeHall, 1970.

-..---., The Justice of Zeus, $2^{\text {nd }}$ ed., Berkeley: University of California Press, 1983.

Lloyd-Jones, Hugh and Parsons, Peter, eds., Supplementum Hellenisticum, Berlin: Walter de Gruyter, 1983.

Lloyd-Jones, Hugh, "The Meropis (SH 903A)," Atti del XVII Congresso internazionale di papirologia, Napoli, 1984, 141-150.

Lohmann, Dieter, Die Komposition der Reden in der Ilias, Berlin: Walter de Gruyter, 1970 .

Louden, Bruce, "Pivotal Contrafactuals in Homeric Epic", CA 12 (1993), 181-198. 
Lynn-George, Michael, Epos: Word, Narrative and the Iliad, London: Macmillan Press, 1988.

Macleod, C.W., Homer, Iliad Book XXIV, Cambridge: Cambridge University Press, 1982.

Martindale, C., Redeeming the Text: Latin poetry and the hermeneutics of reception, Cambridge: Cambridge University Press, 1993.

Matthiae, August, Animadversiones in Hymnos Homericos, cum Prolegomenis, Lipsiae: Libraria Weidmannia, 1800.

Miller, Andrew M., From Delos to Delphi, A Literary Study of the Homeric Hymn to Apollo, Leiden: E. J. Brill, 1986.

Monro, D.B., Homer's Odyssey: Books XIII-XXIV, Oxford: Clarendon Press, 1901.

Murnagham, Sheila, Disguise and Recognition in the Odyssey, Princeton: Princeton University Press, 1987.

Nagler, Michael N., "Towards a Generative View of the Oral Formula", TAPA 98 (1967), $269-311$.

Nagy, G., The Best of the Achaeans: Concepts of the Hero in Archaic Greek Poetry, Baltimore: The Johns Hopkins University Press, 1979.

-------, Greek Mythology and Poetics, Ithaca: Cornell University Press, 1990.

Neils, Jenifer, Greek Mythology and Poetics, Ithaca: Cornell University Press, 1980

------, "Athena, Alter Ego of Zeus", S. Deacy and A. Villing eds., Athena in the Classical World, Leiden: Brill, 2001, 219-232.

Nilsson, Martin P., A History of Greek Religion, tr F.J. Fielden, Oxford: Clarendon Press, 1925.

-------, The Mycenaean Origin of Greek Mythology, Cambridge: Cambridge University Press, 1932. 
O'Brien, Joan V., The Transformation of Hera: A Study of Ritual, Hero and the Goddess in the Iliad, Lanham: Rowman \& Littlefield Publishers, 1993.

Opstelten, J.C., Sophocles and Greek Pessimism, tr. J.A. Ross, Amsterdam: NorthHolland Publishing, 1952. (Originally published in Dutch as a doctoral thesis at the University of Leyden).

Otto, Walter F., The Homeric Gods: The Spiritual Significance of Greek Religion, tr. Moses Hades, London: Thames and Hudson, 1955. (Originally published as Die Götter Griechenlands: Das Bild des Göttlichen im Spiegel des griechischen Geistes, Frankfurt, 1947).

Page, Denys, Sappho and Alcaeus: An Introduction to the Study of Ancient Lesbian Poetry, Oxford: Clarendon Press, 1955.

Palmer, L.R., The Interpretation of Mycenaean Greek Texts, Oxford: Clarendon Press, 1963.

Parry, Hugh, "The Homeric Hymn to Aphrodite: Erotic Ananke", Phoenix 40 (1986), 253-68.

Parry, Milman, The Making of Homeric Verse: the Collected Papers of Milman Parry, ed. A. Parry, Oxford: Clarendon Press, 1971.

Penglase, Charles, Greek Myths and Mesopotamia, Parallels and Influence in the Homeric Hymns and Hesiod, London: Routledge, 1994.

Pope, M.W.M., "Athena's Development in Homeric Epic", AJP 81 (1960), 113-135.

Preziosi, Patricia G., "The Homeric Hymn to Aphrodite: An Oral Analysis", HSCP 71 (1966), 171-204.

Porter, H.N., "Repetition in the Homeric Hymn to Aphrodite", AJP 70 (1949), 249272.

Pritchard, James B. ed., Ancient Near Eastern Texts Relating to the Old Testament, $2^{\text {nd }}$ ed., Princeton: Princeton University Press, 1955.

Propp, Vladimir, Morphology of the Folktale, tr. L. Scott, $2^{\text {nd }}$ ed., Austin: University of Texas Press, 1968. (Originally published as Morfologija skazki, 1928)

Reinhardt, K., Die Ilias und ihr Dichter, ed. U. Hölscher, Göttingen: Vandenhoeck und Ruprecht, 1961. 
Richardson, Nicholas, "Homeric Professors in the Age of the Sophocles", PCPS 21 (1975), 65-81.

------, The Iliad: A Commentary, Vol. VI: books 21-24, Cambridge: Cambridge University Press, 1993.

Rohde, Erwin, Psyche: Seelencult und Unsterblichkeitsglaube der Griechen, $2^{\text {nd }}$ ed., Freiburg: J.C.B. Mohn, 1898.

Roller, Lynn E., In Search of God the Mother: The Cult of Anatolian Cybele, Berkeley and Los Angeles: University of California Press, 1999.

Rose, H.J., "Anchises and Aphrodite", CQ 18 (1924), 11-16.

Rutherford, R.B., "Tragic Form and Feeling in the Iliad", JHS 102 (1982), 145-160.

------, Homer: Odyssey Books XIX and XX, Cambridge: Cambridge University Press, 1992.

------, Homer, Greece \& Rome New Surveys in the Classics 26, Oxford: The Classical Association/Oxford University Press, 1996.

Sale, William, "Aphrodite in the Theogony", TAPA 92 (1961), 508-521.

------, "Achilles and Heroic Values", Arion II-3 (1963), 86-100.

Schmid, W. and Stählin, O., Geschichte der griechischen Literatur, Bd. 1, Munich: Beck, 1929.

Scodel, Ruth, "The Autobiography of Phoenix: Iliad 9.444-95," AJP 103 (1982a), 128136.

------, "The Achaean Wall and the Myth of Destruction", HSCP 86 (1982b), 33-50.

Seaford, Richard, Reciprocity and Ritual: Homer and Tragedy in the Developing CityState, Oxford: Clarendon Press, 1994.

Segal, Charles, The Theme of the Mutilation of the Corpse in the Iliad, Mnemosyne Supplement 17, Leiden: E. J. Brill, 1971.

------, "The Homeric Hymn to Aphrodite: A Structuralist Approach", CW 67 (1974), 205-212. 
-------, "Tithonus and the Homeric Hymn to Aphrodite: A Comment", Arethusa 19 (1986) 37-47.

Shearer, Ann, Athene: Image and Energy, London: Viking Arkana, 1966.

Sherwin-White, Susan M., Ancient Cos: An Historical Study from the Dorian Settlement to the Imperial Period, Hypomnemata 51, Göttingen: Vanderhoeck \& Rupprecht, 1978.

Sihler, Andew L., New Comparative Grammar of Greek and Latin, Oxford: Oxford University Press, 1955.

Slater, Philip E., The Glory of Hera: Greek Mythology and the Greek Family, Princeton: Princeton University Press, 1968.

Slatkin, Laura, The Power of Thetis: Allusion and Interpretation in the Iliad, Berkeley: University of California Press, 1991.

Smith, Peter, Nursling of Mortality: A Study of the Homeric Hymn to Aphrodite, Frankfurt: Verlag Peter D. Lang, 1981a.

------, "Aineiadai as Patrons of Iliad XX and the Homeric Hymn to Aphrodite", HSCP 85 (1981b), 17-58.

Smyth, H.W., Greek Grammar, Cambridge, Mass.: Harvard University Press, 1956.

Solmsen, Friedrich, Hesiod and Aeschylus, Ithaca: Cornell University Press, 1949.

-----, "The Earliest Stages in the History of Hesiod's Text", HSCP 86 (1982), 1-31.

-------, "The Two Near Eastern Sources of Hesiod", Hermes 117 (1989), 413-422.

Sommerstein, Alan H. ed., Aeschylus, Eumenides, Cambridge: Cambridge University Press, 1989

Sourvinou-Inwood, Christiane, 'Reading' Greek Culture, Texts and Images, Rituals and Myths, Oxford: Clarendon Press, 1991.

Sowa, Cora Angier, Traditional Themes and the Heroic Hymns, Chicago: BolchazyCarducci Publishers, 1984. 
Spyropoulos, T. and Chadwick, J. eds., The Thebes Tablets II, Minos 4, Salamanca: Universidad de Salamanca, 1975.

Stanford, W.B., The Odyssey of Homer, vols. I-II, London: Macmillan, 1947-8.

Stanley, Keith, The Shield of Homer, Narrative Structure in the Iliad, Princeton: Princeton University Press, 1993.

Stevenson, T. R., "The Ideal Benefactor and the Father Analogy in Greek and Roman Thought", CQ 42 (1992), 421-436.

Taplin, O., Homeric Soundings: the shaping of the Iliad, Oxford: Clarendon Press, 1992.

Thalmann, William G., Conventions of Form and Thought in Early Greek Epic Poetry, Baltimore: Johns Hopkins University Press, 1984.

Todorov, T., The Poetics of Prose (Translated by R. Howard), Ithaca, New York: Cornell University Press, 1977.

Van der Ben, N., "Hymn to Aphrodite 36-291: Note on the Pars Epica of the Homeric Hymn to Aphrodite", Mnemosyne 39 (1986), 1-41.

Van der Valk, M.H.A.L.H., Textual Criticism of the Odyssey, Leiden: A.W. Sijthoff, 1949.

Van der Valk, M., "On the God Cronus", GRBS 26 (1985), 5-11.

-------, Researches on the Text and Scholia of the Iliad, I-II, Leiden: E.J. Brill, 1963-4.

Van Leeuwen, J., Odyssea, Leiden: A.W. Sijthoff, 1917.

Ventris, Michael and Chadwick, John, Documents in Mycenaean Greek, Cambridge: Cambridge University Press, 1956.

Vermaseren, Maarten J., Cybele and Attis: the Myth and the Cult, tr. A.M.H. Lemmers, London: Thames and Hudson, 1997. (Originally published in Dutch)

Walcot, P., Hesiod and the Near East, Cardiff: University of Wales Press, 1966.

West, M. L., Hesiod: Theogony, Oxford: Clarendon Press, 1966. 
------, "Near Eastern Material in Hellenistic and Roman Literature", HSCP 73 (1969), 113-134.

-------, "Cynaethus' Hymn to Apollo", Classical Quarterly 25 (1975), 161-170.

-, Hesiod: Works and Days, Oxford: Clarendon Press, 1978.

--.----, The East Face of Helicon: West Asiatic Elements in Greek Poetry and Myth. Oxford: Clarendon Press, 1997.

------, Homeri Ilias, vols. 1-2, Leipzig and Munich: Teubner, 1998-2000.

------, Studies in the Text and Transmission of the Iliad, Munich and Leipzig: K.G. Saur, 2001 a.

-------, "The Fragmentary Homeric Hymn to Dionysus", Zeitschrift für Papyrologie und Epigraphik 134 (2001 b), 1-11.

Whitman, C. H., Homer and Heroic Tradition, Cambridge, Mass.: Harvard University Press. 1958.

------, "Hera's Anvils", HSCP 74 (1970), 33 - 57.

Wilamowitz-Moellendorff, Ulrich von, Die Ilias und Homer, Berlin: Weidmann, 1920.

-------, Der Glaube der Hellenen, Basel: Benno Schwabe, 1931-2.

Willcock, M. M., "Mythological Paradeigma in the Iliad", CQ 58 (1964), 141-54.

------, "Ad Hoc Invention in the Iliad", HSCP 81 (1977), 41-53.

------, The Iliad of Homer, Books I - XII, London: Macmillan, 1978.

------, The Iliad of Homer, Books XIII-XXIV, London: Macmillan, 1984.

Zeitlin, Froma I., "Signifying Difference: the Myth of Pandora", in Women in Antiquity, R. Hawley and B. Levick eds., London: Routledge, 1995, 58-74.

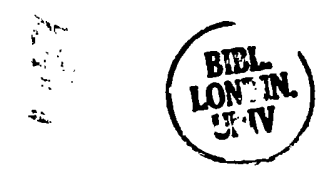

